\title{
CHARLES DIBDIN AND LATE GEORGIAN
}

CULTURE 
Comp. by: SatchitananthaSivam Stage : Revises1 ChapterID: $0003304476 \quad$ Date:20/10/17 Time:19:08:25 Filepath:d:/womat-filecopy/0003304476.3D

OUP UNCORRECTED PROOF - REVISES, 20/10/2017, SPi 


\title{
Charles Dibdin and Late Georgian Culture
}

\author{
Edited by
}

OSKAR COX JENSEN

DAVID KENNERLEY

and

IAN NEWMAN 


\section{OXFORD UNIVERSITY PRESS}

Great Clarendon Street, Oxford, OX2 6DP, United Kingdom

Oxford University Press is a department of the University of Oxford. It furthers the University's objective of excellence in research, scholarship, and education by publishing worldwide. Oxford is a registered trade mark of

Oxford University Press in the UK and in certain other countries

(C) the several contributors 2018

The moral rights of the authors have been asserted

First Edition published in 2018

Impression: 1

All rights reserved. No part of this publication may be reproduced, stored in a retrieval system, or transmitted, in any form or by any means, without the prior permission in writing of Oxford University Press, or as expressly permitted

by law, by licence or under terms agreed with the appropriate reprographics rights organization. Enquiries concerning reproduction outside the scope of the above should be sent to the Rights Department, Oxford University Press, at the address above

You must not circulate this work in any other form and you must impose this same condition on any acquirer

Published in the United States of America by Oxford University Press 198 Madison Avenue, New York, NY 10016, United States of America

British Library Cataloguing in Publication Data

Data available

Library of Congress Control Number: 2017947453

ISBN 978-0-19-881242-5

Printed and bound by

CPI Group (UK) Ltd, Croydon, CR0 4YY

Links to third party websites are provided by Oxford in good faith and for information only. Oxford disclaims any responsibility for the materials contained in any third party website referenced in this work. 


\title{
Foreword
}

\author{
Roger Parker
}

The ERC-funded project from which this book derives had, at its start in 2013, some bracingly ambitious aspirations. Called 'Music in London, 1800-1851', it aimed to construct a wide-ranging interdisciplinary history of its chosen topic, in the process contributing to a new kind of music history. The rationale behind this plan was that previous institutional accounts of Western music-making have mostly-there are of course exceptions-focused on elite culture; whereas 'Music in London' had as its focus a period and a city which, for both material and aesthetic reasons, offered excellent opportunities for exploring a broader and more inclusive kind of history. Music-making in nineteenth-century London, involving as it did a populace of unprecedented size and affluence, functioned as a widelybased industry, providing much professional employment and featuring in the education of many an amateur; it also contributed to private and public enjoyment, became a source of boredom and occasional irritation, and fostered the creation of a host of cultural, political, and imagined communities. A history that took seriously all of these functions might enable twenty-first-century scholars from many fields to understand more fully music's affective presence in nineteenth-century society.

Needless to say, the wider project has of necessity been anything but allinclusive. Certain common themes among its activities have, however, grown to be significant, and one of the most important has been the emergence of a historical approach that tends to erode the usual barriers between what are now usually called 'elite' and 'popular' culture. This has become a focus of many of the project's major activities, but in none has it been more central than the present volume. Indeed, the career of Charles Dibdin might offer something like a one-man illustration of the fruitfulness of mobility between cultural levels: a mobility that, later in the nineteenth century, would become increasingly difficult to achieve, because increasingly imbued with negative associations. In this sense, it is both necessary and important that this book's contributors themselves come from a range of academic disciplines, thus illustrating the kind of eclecticism of purview that made Dibdin himself such a potent force during his career, without relinquishing the benefits of specialization that made him such an object of nostalgia in the long afterlife of his achievements. 
Comp. by: SatchitananthaSivam Stage : Revises1 ChapterID: $0003304476 \quad$ Date:20/10/17 Time:19:08:25 Filepath:d:/womat-filecopy/0003304476.3D

OUP UNCORRECTED PROOF - REVISES, 20/10/2017, SPi 


\section{Acknowledgements}

There is a chance that Charles Dibdin would have approved of this book. As both an inveterate-albeit cantankerous - collaborator, and an autodidact in a remarkable number of professional fields, he would, perhaps, have applauded our study of his cultural world, part of the five-year project 'Music in London, 1800-1851', led by Roger Parker at King's College London, and conducted from the first in a spirit of open and enthusiastic collaboration between scholars of at least six disciplines. And since Dibdin's perennial suspicion of governments, ministries, and their schemes does not appear to have prevented him from accepting institutional funding, he might even have welcomed the generous support of the body that has made this project possible, the European Research Council. The two-day workshop at which this volume was refined, in November 2014, was also the fruit of transatlantic cooperation, held jointly at the University of Notre Dame's London Center, and King's College London's Strand Campus. We would like to thank the staff of both institutions for their help and hospitality, and the Notre Dame College of Arts and Letters and the Institute for Scholarship in the Liberal Arts for their financial support. Above all, we are in the debt of Angela Waplington, the peerless administrator of the 'Music in London' project.

Besides the contributors to this book, that workshop benefited immeasurably from the presence of further friends and colleagues, and we are eternally grateful for the energy and insights of Jeremy Barlow, Jacky Bratton, James Grande, Katherine Hambridge, Jonathan Hicks, Ian Honeyman, Eric Lewis, and Gavin Williams.

As the book assumed its final shape, our various contributors have been helped and guided by others outside these pages, and so we owe our collective thanks to the advice and support of John Barrell, Anna Maria Barry, Olivia Bloechl, Jeanice Brooks, Kathryn Gleadle, Bob Harris, Carmen Holdsworth-Delgado, Essaka Joshua, Greg Kucich, Pollyana Lutz, Marcus Risdell, and Roxann Wheeler.

We owe a further debt to numerous institutions, especially those that have granted permission to reproduce images held in their collections: the British Library, the British Museum, the Casa Goldoni Museum of Venice, The Garrick Club, Harvard's Houghton Library, the National Maritime Museum, the Theatre Museum of London, and the Victoria and Albert Museum.

As contributors, and perhaps especially as editors, we would like to thank our anonymous readers, and also Jacqueline Norton, Catherine Owen, and Aimee Wright of Oxford University Press, and our copy-editor Ian Brookes, for their expert and keen-eyed assistance. Unending thanks go to Roger Parker as instigator of the wider project and pioneer of its working methods. Above all, the three editors can only begin to express their gratitude to their collaborators in this venture: never can there have been such a generous - and efficient! - set of contributors as may be found within these pages. 
Comp. by: SatchitananthaSivam Stage : Revises1 ChapterID: $0003304476 \quad$ Date:20/10/17 Time:19:08:25 Filepath:d:/womat-filecopy/0003304476.3D

OUP UNCORRECTED PROOF - REVISES, 20/10/2017, SPi 


\section{Contents}

List of Figures $\quad$ xi

List of Examples $\quad \mathrm{xv}$

List of Tables $\quad$ xvii

List of Abbreviations $\quad$ xix

List of Contributors $\quad$ xxi

A Chronology of Charles Dibdin $\quad$ xxv

1. Introducing Mr Dibdin 1

Ian Newman, Oskar Cox Jensen, David Kennerley

\section{PART I. DIBDIN IN CONTEXT}

2. 'Mungo Here, Mungo There': Charles Dibdin and Racial Performance 23 Felicity Nussbaum

3. Dibdin at the Royal Circus Michael Burden

Interlude 1. Dibdin and Robert Bloomfield: Voicing the Clown in Town Katie Osborn

4. The Detail is in The Devil: Dibdin's Patriotism in the 1780s David O'Shaughnessy

5. Loyalism, Celebrity, and the Politics of Personality: Dibdin in the 1790s 78 David Kennerley

6. Dibdin and the Dilettantes Judith Hawley

Interlude 2. Dibdin and Jane Austen: Musical Cultures of Gentry Women 108 Nicola Pritchard-Pink

\section{PART II. SONGS IN FOCUS}

7. 'True Courage': A Song in History Oskar Cox Jensen

8. A Motley Assembly: 'The Margate Hoy' Harriet Guest

Interlude 3. Dibdin and John Raphael Smith: Print Culture and Fine Art 158 Nicholas Grindle 
PART III. NINETEENTH-CENTURY TRANSITIONS

9. The Changing Theatrical Economy: Charles Dibdin the Younger at Sadler's Wells, 1814-19

Susan Valladares

10. Writing for Actors: The Dramas of Thomas Dibdin Jim Davis

11. 'Each Song Was Just Like a Little Sermon': Dibdin's Victorian Afterlives

Isaac Land

Afterword: Dibdin's Miscellany Mark Philp

Bibliography

Index 


\section{List of Figures}

2.1. William West, West's New Plate of Harlequins in Various Positions. From original drawings, in possession of Mr. Ellor. Harlequin to the Surrey Theatre. London, 16 March 1824. Engraving. Courtesy of Theatre Museum, London. Victoria and Albert Images/The Art Archive at Art Resource, NY.

2.2. Alexandre Manceau, Harlequin or Arlecchino of 1671. Engraving. From Maurice Sand, Masque et bouffons (comédie italienne): texte et dessins (Paris, 1860). Courtesy of Casa Goldoni Museum, Venice. Photographed by Alfredo Dagli Orti/The Art Archive at Art Resource, NY.

2.3. Butler Clowes, Mr. Dibdin as the Character of Mungo, in the Celebrated Opera of the PADLOCK (1768). London, 1769. Mezzotint. Courtesy of the Harvard Theatre Collection.

2.4. Mr. Dibden in the Character of Mungo. Engraving. From Dramatic Characters, or Different Portraits of the English Stage (London, 1779).

2.5. Isaac Bickerstaff and Charles Dibdin, 'Sung by Mr. Bannister', The Padlock, A Comic Opera: as it is Performed at the Theatre-Royal in Drury-Lane (London, 1768).

3.1. Anonymous, $A$ view of the Royal Circus in St George's Fields. Oil on canvas, c.1795. (C) Victoria and Albert Museum, London.

3.2. Thomas Rothwell, 'The interior of the Royal Circus'. London, 1795. From Lady's Pocket Magazine (London, 1795). Engraving. (C) Enthoven Collection, Victoria and Albert Museum, London.

3.3. Charles Tomkins, Grand Tournament, in the presence of the Emperor Charlemagne in his chariot of chivalry. London, 30 September 1800. Engraving. (C) Trustees of the British Museum.

6.1. 'Sans Souci', Morning Post (8 October 1791). Advertisement. (O) The British Library Board.

7.1. Thomas Rothwell after Benedictus Antonio van Assen, 'Sans-Souci'. From Pocket Magazine (London, c.1796). Engraving. Courtesy of the Trustees of the British Museum.

7.2. George and James Foggo, 'True Courage'. From Illustrations of Dibdin. London, 1830. Lithograph on chine collé. Courtesy of the Trustees of the British Museum.

8.1. A Scene on Board a Margate Hoy, as described by Dibdin. London, 7 January 1804. Hand-coloured etching. Courtesy of The Lewis Walpole Library, Yale University.

8.2. Charles Catton the Elder, Margate Hoy. London, 19 August 1785. Hand-coloured etching. Auchincloss Rowlandson Collection, Beinecke Rare Book and Manuscript Library, Yale University. 
8.3. Isaac Cruikshank, Voyage to Margate. London, 1 January 1786. Hand-coloured etching. Courtesy of The Lewis Walpole Library, Yale University.

8.4. Charles Dibdin, 'Blow high, blow low'. London, 1794. Song slip. The Bodleian Libraries, The University of Oxford, Harding B 11 (334).

8.5. Charles Dibdin, 'Jackey and the Cow'. London, 1796. Engraving. (C) Museum of London.

8.6. Charles Dibdin, 'The Fair'. London, 1793. Engraving. The Bodleian Libraries, The University of Oxford, John Johnson Collection: Ballads, fol. 357a.

8.7. Charles Dibdin, 'The Greenwich Pensioner'. London, 1791. Hand-coloured etching. Courtesy of The Lewis Walpole Library, Yale University.

8.8. Charles Dibdin, 'The Advantage of Toping'. London, 1807. Etching. Courtesy of the Trustees of the British Museum.

8.9. Robert Clamp after George Morland, The Contented Waterman. London, 1797. Stipple etching. Courtesy of the Trustees of the British Museum.

8.10. Robert Clamp after George Morland, Jack in the Bilboes. London, 1797. Stipple etching. Courtesy of the Trustees of the British Museum.

8.11. (a) William Ward after George Morland, The Contented Waterman. London, 1806. Mezzotint. Courtesy of the Trustees of the British Museum. (b) William Ward after George Morland, Jack in the Bilboes. London, 1790. Mezzotint. Courtesy of The Lewis Walpole Library, Yale University.

8.12. Thomas Rowlandson, Margate Hoy. London, 12 January 1795. Hand-coloured etching. Private collection.

8.13. Thomas Rowlandson, A Fresh Breeze. London, 4 August 1789. Etching. Courtesy of The Lewis Walpole Library, Yale University.

8.14. Piercy Roberts, A Sketch on board a Margate Hoy!! London, c.1795-1805. Hand-coloured etching. Courtesy of The Lewis Walpole Library, Yale University.

I3.1. 'Poll and my Partner Joe'. London, 1794. Mezzotint, $36.7 \times 27 \mathrm{~cm}$. (C) National Maritime Museum, Greenwich, London.

I3.2. Anon., The Elopement, London, 1795. Hand-coloured mezzotint, $35 \times 24.5 \mathrm{~cm}$. Courtesy of the Trustees of the British Museum.

I3.3. John Raphael Smith after George Morland, The Elopement, London, 1789. Stipple engraving, $47 \times 35.3 \mathrm{~cm}$. Courtesy of the Trustees of the British Museum.

13.4. Charles Dibdin, Church at Lyme Regis, n.d. Brush drawing in grey wash on paper, $27.1 \times 40.4 \mathrm{~cm}$. Courtesy of the Trustees of the British Museum.

I3.5. Anne Dibdin after Charles Dibdin, 'Approach to Langholm', London, 1801. Aquatint. From Observations. () The British Library Board, 190.c.4-5 vol. 1 facing page 326. 
9.1. Robert C. Andrews, trick scene on flaps for the Sadler's Wells pantomime 'London and Paris' (London, 1816), depicting Hôtel des Invalides.

Pen and watercolour. From Sadler's Wells Scene Book. Courtesy of The Garrick Club, London.

9.2. Robert C. Andrews, trick scene on flaps for the Sadler's Wells pantomime 'London and Paris' (London, 1816), depicting Chelsea Hospital. Pen and watercolour. From Sadler's Wells Scene Book. Courtesy of The Garrick Club, London.

9.3. Robert C. Andrews, trick scene on flaps for the Sadler's Wells pantomime 'London and Paris' (London, 1816), depicting Greenwich. Pen and watercolour. From Sadler's Wells Scene Book. Courtesy of The Garrick Club, London.

11.1. Promotional poster for An Hour with Dibdin and a Miscellaneous Act. London, 1844. Hand-coloured engraving. MS Thr 198 143-144, Houghton Library, Harvard University. 
Comp. by: SatchitananthaSivam Stage : Revises1 ChapterID: $0003304476 \quad$ Date:20/10/17 Time:19:08:26 Filepath:d://womat-filecopy/0003304476.3D

OUP UNCORRECTED PROOF - REVISES, 20/10/2017, SPi 


\section{List of Examples}

7.1. Charles Dibdin, 'True Courage, written \& composed by Mr. Dibdin, and Sung by him in his New Entertainment, called $A$ Tour to the Land's End. Pri.1s. London, Printed \& Sold by the Author, at his Music Warehouse, Leicester Place, Leicester Square.' London, 1798.

7.2. Charles Dibdin arr. Francis Lancelott, 'True Courage', bars 44-50, in Hogarth, vol. 2, 204. 
Comp. by: SatchitananthaSivam Stage : Revises1 ChapterID: $0003304476 \quad$ Date:20/10/17 Time:19:08:26 Filepath:d:/womat-filecopy/0003304476.3D

OUP UNCORRECTED PROOF - REVISES, 20/10/2017, SPi 


\section{List of Tables}

7.1. Unauthorized extant editions of 'True Courage' in cheap print.

11.1. An Hour with Dibdin and a Miscellaneous Act concert programme, Hanover Square Rooms, 2 March 1844. 
Comp. by: SatchitananthaSivam Stage : Revises1 ChapterID: $0003304476 \quad$ Date:20/10/17 Time:19:08:26 Filepath:d:/womat-filecopy/0003304476.3D

OUP UNCORRECTED PROOF - REVISES, 20/10/2017, SPi 


\section{List of Abbreviations}

BL

Bod.

ODNB

Devil

Life

Mentor

Musical Tour

Observations

Fahrner

Hogarth

Kitchiner

Taylor
British Library

Bodleian Library

Oxford Dictionary of National Biography

\section{WORKS BY DIBDIN}

The By-stander; or, Universal Weekly Expositor. By a Literary Association (London, 1789-90)

The Devil, 2 vols (London, 1786-7)

The Professional Life of Mr. Dibdin, written by himself, together with the words of six hundred songs, 4 vols (London, 1803)

The Musical Mentor, or St. Cecilia at School (London, 1805)

The Musical Tour of Mr. Dibdin; in which—previous to his embarkation for India - he finished his career as a public character (Sheffield, 1788)

Observations on a Tour through almost the whole of England, and a considerable part of Scotland, in a series of letters, addressed to a large number of intelligent and respectable friends, 2 vols (London, 1802)

\section{FREQUENTLY CITED TEXTS}

Robert Fahrner, The Theatre Career of Charles Dibdin the Elder (1745-1814) (New York: Lang, 1989)

George Hogarth, The Songs of Charles Dibdin, chronologically arranged, with notes, historical, biographical, and critical, 2 vols (London, 1842, 1848)

William Kitchiner, The Sea Songs of Charles Dibdin, with a memoir of his life and writings by William Kitchiner, M.D. (London, 1823)

Edward Taylor, 'Charles Dibdin', in Royal College of Music, Taylor Collection 2143, Series 6 of 7 of Edward Taylor's lectures on English Dramatic Music, Lecture 3 
Comp. by: SatchitananthaSivam Stage : Revises1 ChapterID: $0003304476 \quad$ Date:20/10/17 Time:19:08:26 Filepath:d:/womat-filecopy/0003304476.3D

OUP UNCORRECTED PROOF - REVISES, 20/10/2017, SPi 


\section{List of Contributors}

Michael Burden is Professor of Opera Studies at Oxford University, and Fellow in Music at New College, where he is also Dean. His research is on the music of Henry Purcell, and on dance and music in eighteenth-century London theatres. He is completing a volume on the staging of opera in London; his five-volume collection of opera documents, London Opera Observed, and his study of Regina Mingotti were both published in 2013. A volume edited with Jennifer Thorp entitled The works of Monsieur Noverre translated from the French: Noverre, his circle, and the English Lettres sur la danse, appeared in 2014. He is Director of Productions of New Chamber Opera (newchamberopera.co.uk).

Oskar Cox Jensen is a Leverhulme Fellow in the Department of History, Queen Mary University of London, prior to which he was a Research Fellow for 'Music in London, 1800-1851' at King's College London. He is the author of Napoleon and British Song, 1797-1822 (Palgrave Macmillan, 2015), and a forthcoming monograph, The London Ballad-Singer, 1792-1864. His current projects are a composite biography of street indigenes in nineteenth-century London, and, with David Kennerley, a series of articles on music and politics, $c .1780-1850$. He has published in journals including Cultural and Social History, Nineteenth Century Theatre and Film, and Studies in Romanticism.

Jim Davis is Professor of Theatre Studies at the University of Warwick. His major research interest is in nineteenth-century British theatre and his most recent books are Comic Acting and Portraiture in Late-Georgian and Regency England (Cambridge University Press, 2015) and Theatre \& Entertainment (Palgrave Macmillan, 2016). He is joint-author, with Victor Emeljanow, of the prize-winning Reflecting the Audience: London Theatregoing 1840-1880 (University of Hertfordshire Press, 2001). A two-volume edition of nineteenth-century dramatizations of Dickens (with Jacky Bratton) for Oxford University Press is currently in production. He is also an editor of the journal Nineteenth Century Theatre and Film.

Nicholas Grindle teaches in the Arena Centre for Research-based Education at University College London. He curated the exhibition George Morland: In the Margins at the Stanley and Audrey Burton Gallery at the University of Leeds in 2015.

Harriet Guest is Professor Emeritus at the Centre for Eighteenth Century Studies and Department of English, University of York. Her most recent book is Unbounded Attachment: Sentiment and Politics in the Age of the French Revolution (Oxford University Press, 2013). Her current research includes a project on British seaside resorts before the railways.

Judith Hawley is Professor of Eighteenth-Century Literature at Royal Holloway, University of London. She is a founding member and, with Mary Isbell, co-director of Researchers in Amateur Performance and Private Theatricals (RAPPT.org). With Mary Isbell, she has guest-edited a special issue of Nineteenth Century Theatre and Film devoted to private and amateur drama. Her essay on the Margravine of Anspach's private theatricals was included in Elaine McGirr and Laura Engell (eds), Stage Mothers: Women, Work and the Theatre 1660-1830 (Bucknell University Press, 2014). In addition, she has published on a broad range of eighteenth-century topics including satire, encyclopaedism, and gender. 
David Kennerley is a Leverhulme Fellow in the Department of History at Queen Mary University of London. His research explores the history of sound, music, and performance in Britain in the long nineteenth century, with a particular focus on sonic aspects of gender, and of political culture. His work has recently been published in the Historical Journal, and has featured in a Bodleian Library exhibition and accompanying book on Staging History, $1780-1840$. He is currently completing a monograph on female singers in early-nineteenthcentury Britain, and, with Oskar Cox Jensen, editing a collection of essays on music and politics from $c .1780-1850$.

Isaac Land is Associate Professor of History at Indiana State University. He is the author of War, Nationalism, and the British Sailor, 1750-1850 (Palgrave Macmillan, 2009), and writes 'The Coastal History Blog' for the Port Towns \& Urban Cultures project (porttowns.port.ac.uk).

Ian Newman is Assistant Professor of English at the University of Notre Dame, where he specializes in eighteenth- and nineteenth-century British and Irish literature. He is currently completing a book, The Tavern: Literature and Conviviality in the Age of Revolution. His work has appeared in Studies in English Literature, European Romantic Review, EighteenthCentury Studies, and Studies in Romanticism. He is also the author of a digital project tracing the meeting places of the London Corresponding Society and is a founding editor of the Keats Letters Project.

Felicity Nussbaum is Distinguished Research Professor at the University of California, Los Angeles, and author of Rival Queens: Actresses, Performance, and the Eighteenth-Century British Theatre (University of Pennsylvania Press, 2010). Among her other books are The Arabian Nights in Historical Context (Oxford University Press, 2008) with Saree Makdisi; The Limits of the Human: Fictions of Anomaly, Race, and Gender (Cambridge University Press, 2003); Torrid Zones: Maternity, Sexuality and Empire (Johns Hopkins University Press, 1995); and The Autobiographical Subject (Johns Hopkins University Press, 1989). Her essays on eighteenth-century drama have appeared recently in The Oxford Handbook of the Georgian Theatre and PMLA. A former president of the American Society for EighteenthCentury Studies, she is pursuing projects on entertainments about slavery and the Orient, as well as a book on Hester Thrale Piozzi.

Katie Osborn is a Ph.D. student in English Literature at the University of Notre Dame. She is currently a scholar advisor to the Indiana Humanities Council and has helped develop Laboring-Class Poets Online, a database of more than 1,600 British and Irish working-class poets of the eighteenth and nineteenth centuries.

David O'Shaughnessy is Assistant Professor for Eighteenth-Century Studies at Trinity College Dublin. He is the author of William Godwin and the Theatre (Pickering \& Chatto, 2010), and has published widely on Godwin and on eighteenth-century theatre. His work has appeared in or is forthcoming in journals such as Eighteenth-Century Life, Journal for Eighteenth-Century Studies, Nineteenth-Century Literature, and HLQ. He is currently working on a project on eighteenth-century theatre censorship and, with Michael Griffin, editing The Cambridge Edition of the Letters of Oliver Goldsmith.

Roger Parker is Professor of Music at King's College London, having previously taught at Cornell, Oxford, and Cambridge. He is General Editor (with Gabriele Dotto) of the Donizetti critical edition, published by Ricordi. His most recent books are Remaking the Song: Operatic Visions and Revisions from Handel to Berio (University of California Press, 2006) and A History of Opera: The Last Four Hundred Years (Penguin, UK, and Norton, US, 
2012), written jointly with Carolyn Abbate. He is now working on a book about music in London in the 1830s, and is Director of the ERC-funded project 'Music in London, 1800-1851'.

Mark Philp is Professor of History and Politics at the University of Warwick, and an Emeritus Fellow of Oriel College, Oxford. He ran a recent Leverhulme-funded project digitizing and editing Godwin's Diary with David O'Shaughnessy and Victoria Myers (godwindiary.bodleian.ox.ac.uk) and a project on Napoleon's Hundred Days with Kate Astbury (100days.eu). He runs 'Re-imagining Democracy c.1750-1850' with Joanna Innes (re-imaginingdemocracy.com). Recent publications include Reforming Political Ideas in Britain: Politics and Language in the Shadow of the French Revolution (Cambridge University Press, 2013), and, with Joanna Innes (eds), Re-imagining Democracy in the Age of Revolutions: America, France, Britain, Ireland, 1750-1850 (Oxford University Press, 2013).

Nicola Pritchard-Pink is a classically-trained singer and former senior archives assistant who completed her Master's degree in Eighteenth Century Studies with distinction at the University of Southampton. She specialized in female domestic music of the late eighteenth and early nineteenth centuries, analysing in particular the extant music collection of Jane Austen. Since then she has continued to research, lecture on, and perform these songs as a semi-professional singer and speaker.

Susan Valladares is a Departmental and College Lecturer in English at St Hugh's College, University of Oxford. Her research interests span the long eighteenth century, with a special focus on theatre and performance, political history, and print culture. Her first book, Staging the Peninsular War: English Theatres 1807-1815 (Routledge, 2015) explores how theatrical entertainments in England reflected and shaped public feeling on the long and bloody attempt to drive French forces out of Spain and Portugal. She is currently writing on the nineteenth-century forms and media that furthered cultural understandings of tragedy, and on early Anglo-American re-enactments of the Caribbean Jonkanoo tradition. 
Comp. by: SatchitananthaSivam Stage : Revises1 ChapterID: $0003304476 \quad$ Date:20/10/17 Time:19:08:26 Filepath:d:/womat-filecopy/0003304476.3D

OUP UNCORRECTED PROOF - REVISES, 20/10/2017, SPi 


\section{A Chronology of Charles Dibdin}

1745 Baptized in Southampton

1764 First stage work performed: all-sung pastoral The Shepherd's Artifice (Covent Garden)

1765 Huge success as Ralph in Isaac Bickerstaff's The Maid of the Mill (CG); signs three-year contract at $C G$ at $£ 3, £ 4$, and then $£ 5 /$ week

1767 Begins relationship with actress Harriet Pitt Plays Watty Cockney in Bickerstaff's Love in the City; composes much of the score

1768 Writes two-thirds of the music for Bickerstaff's Lionel and Clarissa Transfers (with Bickerstaff) to Drury Lane, under Garrick's management Plays Mungo in his and Bickerstaff's opera The Padlock (Drury Lane) Birth of first son, Charles Isaac Mungo

1769 Composes music for Garrick's Shakespeare Jubilee The Recruiting Sergeant, The Maid the Mistress, and The Ephesian Matron all performed at Ranelagh Gardens under a two-year contract (£100/season)

1770 Birth of first daughter, Harriet

1771 Birth of second son, Thomas John

1772 Press accusations of sodomy levelled at Bickerstaff, who flees to France The Palace of Mirth and The Brickdustman performed (Sadler's Wells)

1773 Comic opera, The Wedding Ring, first performed anonymously (DL); riot when audience assumes it is by Bickerstaff, forcing Dibdin to acknowledge authorship

1774 The Waterman first performed (Haymarket)

1775 Marries Anne Maria Wylde Discharged from DL after disputes with Garrick Baptism of second daughter, Anne Flees to France to escape creditors Opera The Seraglio performed in his absence (CG)

1778 Returns to Britain after France enters War of American Independence Employed as house composer at $£ 10$ /week until 1782 (CG)

1782 Enters partnership to manage Royal Circus and Philharmonic Academy; continues on and off until 1785

1786 Begins publication of a periodical, The Devil, until 22 Feb 1787

1787 First musical tour of Britain

1788 Publishes Musical Tour Journey to India abandoned due to storms in Bay of Biscay

1789 First London solo show, The Whim of the Moment (King Street) Begins publishing second periodical, The By-Stander, until 6 Feb 1790 Second solo show, The Oddities (Lyceum) 
OUP UNCORRECTED PROOF - REVISES, 20/10/2017, SPi

xxvi

A Chronology of Charles Dibdin

1791 Opens first Sans Souci theatre, 411 Strand, with Private Theatricals

1793 Publishes novel, The Younger Brother

1795 Christmas Gambols includes 'The Margate Hoy' (Sans Souci)

1796 Publishes second novel, Hannah Hewit, or, The Female Crusoe

Builds second, 500-seat Sans Souci Theatre, Leicester Place, for $£ 6,000$

Opens with The General Election

1797 Publication of five-volume Complete History of the English Stage until 1800

1798 Tour of Kent and Sussex, followed by a tour to Land's End A Tour to the Land's End includes 'True Courage' (Sans Souci)

1800 After further touring, publishes Observations until 1802

1803 Publishes The Professional Life Awarded pension of $£ 200$ by Addington administration; publishes British War Songs Britons Strike Home (Sans Souci)

1805 First retirement from performance Publishes Musical Mentor

1807 Pension revoked by Grenville administration; returns to London to work Publishes third novel, Henry Hooka

1808 Professional Volunteers (Lyceum); Rent Day (Sans Pareil); The Melange (Assembly Rooms, Cateaton Street, and the Sans Pareil)

1809 Commodore Pennant (Dibdin's Music Rooms, 125 Strand)

Declared bankrupt

1810 Public dinner raises $£ 640$

1811 Play The Round Robin closes after two nights (Haymarket)

1814 Death 


\title{
1
}

\section{Introducing Mr Dibdin}

\author{
Ian Newman, Oskar Cox Jensen, David Kennerley
}

\begin{abstract}
The conjectures concerning me are beyond number and credibility. Every man seems to have made of me just what suited his pleasure or convenience. I have been seven years in the West Indies, to learn how to perform Mungo; I have been three voyages to sea, as a surgeon of a man of war, to teach me seaphrases; I have long enjoyed a private pension for my staunch attachment to government; and I have done a variety of other things, which are equally devoid of foundation. ${ }^{1}$
\end{abstract}

With these typically forthright words Charles Dibdin (1745-1814) introduces himself in his four-volume autobiography, The Professional Life of Mr Dibdin. He presents himself by declaring he needs no introduction: 'every man' knows Dibdin and is consequently free to make of him what he will. In the face of a deluge of false conjecture, The Professional Life attempts to set the record straight, declaring the author's commitment to truth over rumour, while simultaneously stoking the fires of the fame that had produced those rumours in the first place. For all the bluster of Dibdin's prose, it would be hard to argue with the extent of his fame. $\mathrm{He}$ was an extremely well-known public character in the late eighteenth and early nineteenth centuries: an actor, singer, novelist, multi-instrumentalist, theatre manager, songwriter, journalist, publisher, and pioneer of the one-man show whose contribution to late Georgian culture is as irrefutable as it is hard to characterize. It is the contention of this volume that any serious consideration of late Georgian culture needs to engage not only with Dibdin himself but also with a culture that was able to sustain this kind of multifarious, polymathic, and intermedial career, for which Dibdin's name became a byword. ${ }^{2}$

Today it is perhaps less clear that Dibdin needs no introduction. While his name has frequently appeared in accounts of eighteenth-century theatre and culture, his importance acknowledged by scattered references, he has rarely been the object of

1 Life, 1:2.

2 See, for example, Coleridge's letter in Blackwood's Magazine in which he expresses his desire for a full collection of religious symbols published in books, a project which would 'well employ the talents of our ingenious masters in wood-engraving, etching, and lithography under the superintendence of a Dibdin'. Blackwood's Edinburgh Magazine 10 (1821): 257n. Thanks to Essaka Joshua for the reference. 
sustained attention. ${ }^{3}$ Exceptions exist, most notably Robert Fahrner's The Theatre Career of Charles Dibdin the Elder (1989) and E. R. Dibdin's A Charles Dibdin Bibliography (1937), and Dibdin plays a crucial role in Peter Tasch's biography of Isaac Bickerstaff. But these works inhabit a highly specialized position in the twentieth-century historiography of the period, far removed from the widespread appeal that his works enjoyed in the late eighteenth and throughout the nineteenth centuries. ${ }^{4}$ There are, however, numerous signs of a revival of interest in Dibdin, both as an individual and as an important exemplar of late Georgian cultural trends. He has been central to Jacky Bratton's work across several books mapping the transitions from the eighteenth-century stage to Victorian theatrical traditions; ${ }^{5}$ he has become important for scholars interested in the history of the representation of race on the British stage, mainly through his performances as Mungo in The Padlock, though also more recently through his depictions of the Orient; ${ }^{6}$ scholars interested in the role that song played in the dissemination of loyalist ideas in Britain during the Napoleonic era have been drawn to the influence of his songs; ${ }^{7}$ Jeremy Barlow is in the process of a thorough documentation of his regional tours; ${ }^{8}$ within studies of the novel, Dibdin's Hannah Hewit is receiving belated recognition as an important rewriting of the Crusoe myth; ${ }^{9}$ Peter Holman has recently argued for Dibdin's importance as 'the first English composer who could handle' the new Italian 'gallant' style 'with assurance', ${ }^{10}$ while the continuing popularity of his songs among a nineteenth-century polite audience, from Jane Austen's songbooks to the

3 See, for example, John Brewer, The Pleasures of the Imagination: English Culture in the Eighteenth Century (New York: Routledge, 2013), 315-16; Jane Moody, Illegitimate Theatre in London, 1770-1840 (Cambridge: Cambridge University Press, 2000), 24; Gillian Russell, Women, Sociability and the Theatre in Georgian London (Cambridge: Cambridge University Press, 2007), 136.

${ }^{4}$ Fahrner; E. Rimbault Dibdin, A Charles Dibdin Bibliography (Liverpool: Privately Printed, 1937); Peter A. Tasch, The Dramatic Cobbler: The Life and Works of Isaac Bickerstaff (Lewisburg: Bucknell University Press, 1972).

5 Jacky Bratton, The Victorian Popular Ballad (Totowa, NJ: Rowman and Littlefield, 1975), 41-2; New Readings in Theatre History (Cambridge: Cambridge University Press, 2003), 21, 120; The Making of the West End Stage: Marriage, Management and the Mapping of Gender in London, 1830-1870 (Cambridge: Cambridge University Press, 2011), 37.

6 Julie A. Carlson, 'New Lows in Eighteenth-Century Theatre: The Rise of Mungo', European Romantic Review 18/2 (2007): 139-47; Daniel O'Quinn, 'Theatre, Islam and the Question of Monarchy' in Julia Swindells and David Francis Taylor (eds), The Oxford Handbook of the Georgian Theatre, 1737-1832 (Oxford: Oxford University Press, 2014), 651.

7 Isaac Land, War, Nationalism, and the British Sailor, 1750-1850 (Basingstoke and New York: Palgrave Macmillan, 2009), 89-99, 112-15; Mark Philp, Reforming Ideas in Britain; Politics and Language in the Shadow of the French Revolution, 1789-1815 (Cambridge: Cambridge University Press, 2014), 238-57; Oskar Cox Jensen, Napoleon and British Song, 1797-1822 (Basingstoke and New York: Palgrave Macmillan, 2015).

8 Jeremy Barlow, 'Dibdin on Tour', Early Music Performer 39-40 (forthcoming).

9 Maximillian E. Novak, 'Ideological Tendencies in Three Crusoe Narratives by British Novelists during the Period Following the French Revolution: Charles Dibdin's Hannah Hewit, The Female Crusoe, Maria Edgeworth's Forester, and Frances Burney's The Wanderer', Eighteenth-Century Novel 9 (2012): 261-80; Andrea Haslanger, 'From Man-Machine to Woman-Machine: Automata, Fiction and Femininity in Dibdin's Hannah Hewit and Burney's Camilla', Modern Philology: Critical and Historical Studies in Literature, Medieval Through Contemporary 11/4 (2014): 788-817.

10 Peter Holman, 'The Sadler's Wells Dialogues of Charles Dibdin' in Rachel Cowgill, David Cooper, and Clive Brown (eds), Art and Ideology in European Opera: Essays in Honour of Julian Rushton (Woodbridge: The Boydell Press, 2010), 164. 
Victorian drawing room, is increasingly apparent; ${ }^{11}$ and theatre historians have begun to explore individual pantomime entertainments, such as Vineyard Revels; or Harlequin Bacchanal, The Lancashire Witches; or the Distress of Harlequin, and The Touchstone; or, Harlequin Traveller. ${ }^{12}$ The great difficulty with Dibdin scholarship, as this brief overview begins to suggest, is in the huge diversity and impact of his work; he is important to many different fields for often quite dissimilar reasons, and a sense of his overall accomplishments - never mind the powerful reverberations of his influence-across numerous areas and in different periods has been ill-served by the disciplinary boundaries of our fields of academic enquiry.

Even in Dibdin's own account it is far from obvious why he was so well known. The quotation above suggests three aspects of his career which he believed to be the source of his renown: his character Mungo, the black servant he played in Bickerstaff's 1768 afterpiece opera The Padlock, for which he also wrote the music, and which was the first entertainment on the British stage to feature a fullydeveloped comic blackface role as a hero or anti-hero; his sea-phrases, a reference to the immense popularity of the songs, such as 'Tom Bowling', he wrote about sailors in a patriotic and sentimental mode; and finally, the role these songs played in developing a loyalism that appeared to stabilize the nation after the political controversies of the early 1790s. According to The Professional Life, these aspects of his career-his acting, his songwriting, his politics-have resulted in a degree of fame and accompanying public scrutiny that is at once invasive and inaccurate and for which it is Dibdin's duty, he feels, to compensate by providing an authoritative account of his career.

As a text, however, The Professional Life — or, to give the full title, The Professional Life of Mr Dibdin, Written by Himself Together with the Words of Six Hundred Songs Selected from his Works Interspersed with Many Humourous and Entertaining Anecdotes Incidental to the Public Character-obscures more than it illuminates. In the first place, it is not a standard autobiography, but an account only of his 'professional life'. It attempts (with mixed results) to eschew the private and the personal in order to present the authoritative 'public' Dibdin. He is, he insists, a skilled worker, and he wants to share his career, not his dirty laundry. His fame does not mean he has to surrender access to all aspects of his life, and he maintains a professional distance, characterized by calling himself 'Mr Dibdin', not Charles. Though far from humourless, Dibdin introduces himself with a sense of moral probity that is at times severe. Yet accounts of his one-man shows, performed around the time The Professional Life was written, suggest that part of Dibdin's charm was precisely his easy familiarity, the back-and-forth chatter with audience

11 Derek B. Scott, The Singing Bourgeois: Songs of the Victorian Drawing Room and Parlour, (2nd edn, Aldershot: Ashgate, 2001); Gillen D'Arcy Wood, Romanticism and Music Culture in Britain, 1770-1840 (Cambridge: Cambridge University Press, 2010), 153, 160.

12 David Worrall, Theatric Revolution: Drama, Censorship and Romantic Period Subcultures 1773-1832 (Oxford: Oxford University Press, 2006), 182-4; Frederick Burwick, Playing to the Crowd: London Popular Theatre, 1780-1830 (Basingstoke and New York: Palgrave Macmillan, 2011), 177-8; John O’Brien, 'Pantomime', in Jane Moody and Daniel O'Quinn (eds), The Cambridge Companion to British Theatre, 1730-1830 (Cambridge: Cambridge University Press, 2007), 108-9. 
members, and the energy with which he introduced himself as he came bounding out onto the stage, laughing warmly, rubbing his hands together and greeting audience members like old friends. ${ }^{13}$ All part of the act, no doubt, but Dibdin presented a very different character in performance than the identity presented in his autobiography, suggesting his cautiousness around the public scrutiny he associated with print, and raising questions about the limits of The Professional Life's claims to authenticity.

The second way The Professional Life can be seen as an obfuscating text is in its form. It is not simply an account of his career, but a combination of an autobiographical narrative and a selected works, containing the words to around six hundred of his songs. Part of Dibdin's point is to insist on the sheer quantity of his output. He is prolific, he wants you to know, a hard worker who deserves your approbation in part because of his ceaseless energy and dedication to his craft. In fact these six hundred songs are only one small part of his complete output. The total number of his songs amounted to something in the region of a thousand, ${ }^{14}$ not to mention the music (ballets, burlettas, comic operas, incidental music, intermezzos, pantomimes) he wrote for Covent Garden, Drury Lane, Haymarket, Ranelagh Gardens, the Royal Circus, and Sadler's Wells, the full extent of which we will probably never know. And this is to ignore his other written works: his journalism in The Devil and The By-stander, his accounts of his musical tours, his novels The Younger Brother and Hannah Hewit, his History of the English Stage- to say nothing of the three musical textbooks and one further novel that were published after The Professional Life. The authorized Dibdin that we get in The Professional Life is introduced to us primarily as a songwriter, though it is by no means certain that this is his primary claim to fame. Earlier in his career he was known as an actor and singer, then as a theatre manager and innovator of equestrian entertainments at the Royal Circus. Much of his tremendous output receives scant attention as he tries to curate his legacy for the tastes of an early-nineteenth-century audience increasingly attracted to specialized talents rather than the miscellaneous activities that typified his earlier career.

In the early years of the nineteenth century Dibdin was known as a writer of sea songs that had helped to shape the popular image of the navy, although this was only ever a tiny percentage of his overall output-he wrote about ninety sea songs. Dibdin, frequently in financial straits, was rarely shy to seize a commercial opportunity when he saw one, and, whatever else it might also be, The Professional Life is unambiguously an attempt to make some money by collecting together the words to his most popular songs and presenting them in an expensive, collectable fourvolume edition. When we read the way that Dibdin introduces himself to us, then, we need to be alert to the fact that he is giving his early-nineteenth-century readers what he thinks they want. The success of the attempt might be measured by the fact that The Professional Life never made it to a second edition.

The third way in which The Professional Life obscures as much as it illuminates is in its anecdotal nature. It is 'interspersed', the title tells us, with 'Many Humourous

\footnotetext{
13 See Fahrner, 122, and discussions by Kennerley, Cox Jensen, and Hawley in this volume.

14 See Hogarth, 'Preface' [unpaginated].
} 
and Entertaining Anecdotes Incidental to the Public Character'. It participates, that is, in the fashionable form of the theatrical anecdote. The problem is that it is to the realm of the anecdote - the conjectural, engaging, short biographical narrativethat the authorized life offers itself as a corrective. And this is just one of the apparent contradictions in Dibdin's turn to the anecdotal. The term 'anecdote' derives from the Greek, an- 'not' + ekdotos 'published', and was defined in Samuel Johnson's Dictionary as 'something left unpublished; secret history'. Any published anecdote is by definition a kind of paradox, but one that can be resolved by the anecdote's apparent ability to reveal the hidden life. As Helen Deutsch has argued of the anecdotes collected about Samuel Johnson by Boswell and others, anecdotes reveal the desire for an intimate connection with the subject matter, to move beyond, to supplement, and even to supplant authoritative published accounts. ${ }^{15}$ To publish an anecdote, then, is to make available for a public that which would otherwise be left secret, thereby preserving these intimate histories for posterity. The anecdotal form of The Professional Life reveals a tension between Dibdin's desire to establish an authoritative account — just the facts, none of the conjecture-and a desire to forge an intimate connection with his audience through entertaining stories. This is, perhaps, one of the key tensions operating throughout Dibdin's career: his competing desire for moral probity assured by manly independence, and the approval of a public upon which he relied for financial support. ${ }^{16}$ We can see this in terms of a tension between Dibdin's eighteenth-century moral and social sensibility and his often forward-looking commercial instincts, born of his economic dependence upon a marketplace of which he remains suspicious even as he exploits its potential.

The anecdotal form of The Professional Life is also Dibdin's attempt to shape his reputation, to shore up the facts that will carry his name into immortality. 'Anecdotes', Bratton writes, 'are chiefly important as a control of social resources through the making of myth and legend'. ${ }^{17}$ And while this kind of myth-making can seem egregiously self-aggrandizing, Bratton argues that they also embed the storyteller in a social world and reveal that world to us: 'the recounting of anecdotes, which are the building blocks of theatrical memoir and biography, may be understood not simply as the vehicle of more or less dubious or provable facts, but as a process of identity-formation that extends beyond individuals to the group or community to which they belong' ${ }^{18}$

There are, then, two different ways to think about the anecdote: an eighteenthcentury form that reveals the secret history of a beloved figure to a grateful public, and a later nineteenth-century iteration in which theatre people tell stories about themselves, thereby revealing the social world in which they are embedded. Dibdin is caught between these two models, inclining towards the later idea but steeped in the attitudes of an earlier moment, and wary of the implied egocentrism of the nineteenth-century teller of tall tales-his own anecdotes, he claims somewhat disingenuously, are about 'the Public Character', not about himself.

15 Helen Deutsch, Loving Dr Johnson (Chicago: Chicago University Press, 2005), 20.

16 See Kennerley, Chapter Five in this volume. $\quad 17$ Bratton, New Readings, 102-3.

18 Ibid. 
While The Professional Life was not the resounding commercial success for which Dibdin doubtless hoped, it was nevertheless profoundly successful in shaping Dibdin's posthumous reputation. The Dibdin it presents-a loyalist writer of melodious sea songs - is very much the Dibdin that Victorians celebrated and held dear, as Isaac Land shows in Chapter Eleven. It is no coincidence that Dibdin is most often remembered today as the author of 'Tom Bowling', one of the tunes included in Sir Henry Wood's Fantasia on British Sea Songs, written in 1905 to mark the centenary of the Battle of Trafalgar and still a staple of the BBC's Last Night of the Proms. Most accounts of Dibdin's life understandably take the autobiography as an authoritative starting point. But to recognize The Professional Life as a self-conscious attempt to shape his reputation by catering to the tastes of his nineteenth-century audience is to suggest that there are other, earlier Dibdins to whom we also need to be introduced.

The Dibdin of The Professional Life is primarily a songwriter, one born into modest circumstances and who eschewed professional training, thereby preserving his own innate talent and ear for melody. As Katie Osborn suggests in this volume, there are similarities between this account and the narratives of labouring-class poets such as Robert Bloomfield, Robert Burns, Stephen Duck, and Anne Yearsley, who would exert a powerful influence on the development of British Romantic poetry. This account, however, is tailored to an audience receptive to tales of the natural genius of unschooled bards, a tale that relies on specialization. It is one thing to believe with William Wordsworth that an unschooled genius might 'naturally' be endowed with the qualities that make it possible to express 'the goings-on of the Universe', but it is another thing entirely to believe that such a person might also be a 'naturally' talented actor, singer, composer, theatre manager, piano player, journalist, publisher, and so on. The early-nineteenth-century conception of the individual genius requires a degree of specialization that Dibdin's career does not sustain. To recognize Dibdin's achievements, then, we need to be open to a different model of cultural production, one that depends on two principles that are obscured by The Professional Life: an appreciation of miscellany as an artistically valid model of production, and a recognition of the social embeddedness of the producer of the cultural artefact.

\section{THE ART OF MISCELLANY}

In The Great Transformation of Musical Taste (2008) William Weber argues that a significant change took place in concert programming across a period that loosely corresponds to the years in which Dibdin was active. In the mid-eighteenth century, Weber argues, there were relatively few concerts, so that musicians and listeners understood the need to be tolerant of a wide diversity of musical tasteswhat Weber calls the collegiality of eighteenth-century musical culture. Concert programs typically included as many as fifteen items ranging from operatic numbers, symphonies, and concertos, to instrumental solos, string quartets, and songs. By the mid-nineteenth century a new order had come into being, characterized by 
more specialized music programming, often focused on one particular composer or a single genre, with an overpowering presence of music from the past. 'Classical music' had achieved hegemonic status, and new types of miscellaneous concerts, including 'ballad concerts, music halls, cafés-concerts and programs of opera excerpts and songs' were organized for the general public with only a limited relationship to the classical concerts. ${ }^{19}$

Beyond the world of concert programming that primarily concerns Weber, similar shifts occurred in other fields of cultural production. Collections of poetry entitled Miscellany Poems, by poets such as Dryden, Finch, Mandeville, Pomfret, Pope, and Wycherley, gave way to collections of poetry with increasingly specialized titles such as Elegiac Sonnets (Smith), Lyrical Ballads (Coleridge and Wordsworth), Poems Written in Close Confinement in the Tower (Thelwall), and Songs of Innocence and Experience (Blake). The pleasing juxtapositions of the early modern cabinet of curiosities gave way to the more rigid temporal and spatial segregations of the museum, as the empiricist urge to classify and categorize took on ever wider institutional forms. Within the theatre the miscellaneous plays, pantomimes, spectacles, puppet shows, and entertainments which jostled together in the late-eighteenth-century patent theatres gave way to a system in which Covent Garden and Drury Lane increasingly specialized in cultural forms that possessed high cultural capital, such as Shakespeare, which had little to do with the comic turns and entertainments of the Victorian music hall. ${ }^{20}$

One might speculate that Dibdin's career registers some of the pressures that produced this partitioning of cultural forms. We can see how the transformation impacts Dibdin's narrative of his career, as he begins the account of his professional life with a broad range of creative projects, many of them collaborative, and ends his career claiming to be a specialist songwriter working alone at his one-man shows, or what he called 'table entertainments'. But this account is highly unconvincing. Dibdin's later years were characterized just as much by a diversity of projects (including publishing ventures, the musical textbooks, his novel writing, and his autobiography) as his earlier work in theatres and pleasure gardens. Nevertheless, Dibdin's narrative indicates the pressures to conform to the expectations of specialization, even if this was never actualized in practice. Practically speaking, then, we can think of Dibdin's career as an exemplary miscellany that exposes the contradictions and dilemmas that came into being as the increasing drive towards specialization was experienced on an individual basis.

More broadly, however, Weber's account of the transformation in musical taste insists that the shift in musical culture corresponds with political developments: 'The breakup of musical life took place within a context of deep instability in

19 William Weber, The Great Transformation of Musical Taste: Concert Programming from Haydn to Brahms (Cambridge: Cambridge University Press, 2008), 3. See also Christina Bashford, The Pursuit of High Culture: John Ella and Chamber Music in Victorian London (Woodbridge: Boydell \& Brewer, 2007).

20 Though see Bratton, West End Stage for an account of the wide diversity of theatrical experience available in the West End in the mid-nineteenth century. 
European politics and society between 1789 and $1848 .{ }^{21}$ The transformation from the miscellaneous and collegial society of the late eighteenth century to a world of increasingly specialized concert performance in the nineteenth is thus for Weber a manifestation of broader political, social, and economic transformations that produced an 'efflorescence of utopian thinking about ideal communities or the reform of professional or cultural worlds' ${ }^{22}$ This is not to say that the cultural transformations Weber observes were a direct result of, or straightforwardly analogous to, revolution-the pathways of cultural change are rarely so direct-but they are nevertheless manifestations of a period of intense re-visioning of the relationship between individuals and groups, and between different communities that were instantiated in a variety of (sometimes contradictory) ways.

In Dibdin's case the political context for his work is crucial because he was so frequently associated - by others, if not by himself - with political events as they were unfolding. Most obviously, his sea songs have frequently been credited with changing the reputation of the Royal Navy during the Napoleonic conflicts, and helping to produce a sense of unity and loyalism after the fierce political contests of the 1790 s. $^{23}$ This was a perception Dibdin himself was keen to endorse. To the extent that Dibdin's songs effectively contributed to a more united nation, his works, in both print and performance, partake of the new opportunities for 'imagining' the nation opened up by the expansion of the public sphere as described by Benedict Anderson and Linda Colley. ${ }^{24}$ Yet Dibdin's patriotism was far from straightforward; it is notable, for instance, that his sea songs are rarely explicitly political, most often celebrating the manly beauty of the individual sailor, rather than the nation as a collective entity.

Earlier, when he set up his first Sans Souci theatre at 411 Strand it was alleged that Pitt's administration had supported the venture in order to counteract the effect of the political radical John Thelwall's lectures, which were taking place directly opposite in the Beaufort Buildings. Dibdin himself denied this claim-as well he might, as his first Sans Souci entertainment, 'Private Theatricals, or Nature in Nubibus' opened in October 1791, long before Thelwall moved into the Beaufort Buildings in early $1794 .{ }^{25}$ Yet it is perhaps notable that one of the 'large field of objects' enumerated in the handbill for the first Sans Souci entertainment was 'The Rights of Man'. ${ }^{26}$ Dibdin's attitude towards the discourse of Rights might be glimpsed in his song 'Bill Bobstay', originally performed as the final song in 'Private Theatricals'. Bill Bobstay is a 'kind' and 'true' sailor whose heart is generous though he is 'poor as a beggar', and the song concludes with the following stanzas:

21 Weber, The Great Transformation, $2 . \quad 22$ Ibid.

23 See, for example, The Satirist 3 (1808): 239-45.

24 Benedict Anderson, Imagined Communities: Reflections on the Origin and Spread of Nationalism (Revised edn, London: Verso, 2006); Linda Colley, Britons: Forging the Nation 1707-1837 (2nd edn, New Haven: Yale University Press, 2005).

25 For the dates of 'Private Theatricals', see Fahrner, 224; for Thelwall in the Beaufort Buildings, see Judith Thompson, 'From Forum to Repository: A Case Study in Romantic Cultural Geography', European Romantic Review 15/2 (2004): 177-91, 179; for Dibdin's denial, see Life, 4:6.

26 See Hawley, Chapter Six in this volume. 
Why, what's all this nonsense they talks of, and pother, About rights of man? What a plague are they at? If they mean that each man to his messmate's a brother, Why, the lubberly swabs, ev'ry fool can tell that.

The right of us Britons we know's to be loyal, In our country's defence our last moments to spend, To fight up to the ears to protect the blood royal,

To be true to our wives, and to succour a friend. ${ }^{27}$

The song's gesture of dismissing the still nascent revolution debates in order to assert the 'natural' domestic and political loyalty inherent in a community tied together by warm-hearted homosocial generosity is about as explicit a political statement as Dibdin ever made, though it is notably mediated through the fictional character of the song's speaker-a sailor who has sailed with Bill Bobstay. It is not so much that Dibdin has no political conviction as that he chooses to rechannel the potentially volatile energies of politics into entertainment, to tackle serious issues in a light-hearted way-as much a commercial decision as a political one, no doubt, but a decision that makes explicit the politics of commerce: if one seeks a wide market, it is wise to steer clear of controversial topics that might alienate potential audience members.

Long before the inescapable politicization of the 1790s, Mungo, the West Indian character whose status rests ambiguously between that of a servant and a slave, and whom Dibdin performed to such wide acclaim in The Padlock, played a conspicuous role in debates about abolition. Felicity Nussbaum argues in this volume that Dibdin had no firmly held views on abolition or slavery, but turned his representation of race into a laughing matter in order to contain the threat of the potentially chaotic and disruptive forces of slavery. Here comedy functions similarly to sentimentality in the later table entertainments, though Dibdin's own desire to sidestep the politically volatile by rechannelling contentious debate into laughter and sentiment might not always have had the desired effect on his audience. As Nussbaum points out, Dibdin was consistently drafted into arguments about the slave trade, no doubt in part because he was so closely identified with Mungo. In his Musical Tour, Dibdin distances himself from political position-taking on the question of abolition: 'it would have exceeded my duty to say whose arguments are the most worthy [of] attention'. ${ }^{28}$ Yet his audience's response was often far less equivocal, and it is clear that Dibdin provoked precisely the kind of political debate that he was eager to evade.

Despite his attempts to the contrary, at key points in his career Dibdin's work flares up with political energy, exposing the interpenetration of politics and popular commercial performance characteristic of a period when the relationship between the popular and the political underwent a sustained and thoroughgoing examination. Indeed, it is possible to understand the shift from the miscellaneous to the specialized as an epiphenomenon of larger changes in attitude towards the popular, as outlined in Peter Burke's seminal study Popular Culture in Early Modern Europe,

27 Hogarth, 1:111. $\quad 28$ Musical Tour, 232. 
which traces the increasing polarization between the elite and popular from the sixteenth through the nineteenth centuries. In Europe in 1500, Burke argues, 'popular culture' belonged to everyone. While the educated few had access to a separate elite tradition, they also participated in the popular traditions of the entire population. By 1800, however, the educated elite had 'abandoned popular culture to the lower classes, from whom they were now separated, as never before, by profound differences in world view'. ${ }^{29}$ While the scope and chronological spans differ between Burke's and Weber's accounts, their overall arguments are neatly compatible, both seeing a basic shift in attitudes towards the popular and an increased specialization of cultural forms by the early nineteenth century. This reinforces the idea that the transformation in music programming that concerns Weber was one aspect of larger-scale developments observable also in theatre, literature, and art, for example-at all of which Dibdin tried his hand, in the midst of a rapidly shifting terrain of cultural hierarchies. Increasingly, Dibdin saw his miscellaneous artistic endeavours becoming regarded as low or popular while he continued to insist on his moral and cultural legitimacy.

It would, however, be a mistake to think of the transformation from miscellany to specialization as a shift from riotous confusion to orderly classification. Miscellany is itself a form of order, requiring a robust, organized sequencing of elements. While to its critics (such as the third Earl of Shaftesbury) miscellany was ridiculed as a 'patchwork', within a culture of performance that attempted to cater to the varied needs of different audience members it could be an admirable organizing principle, and when handled with discipline and intelligence could lend a pleasing variety to a concert programme. ${ }^{30}$ Moreover, the principle of miscellany dictated that 'members of the musical community had to accommodate one another's tastes and social etiquette. All who entered a concert knew that they were expected to defer to the wishes of others to some extent. ${ }^{31}$

This might, however, be an idealized description of what actually went on at musical gatherings. There are accounts of disagreements, complaints, and general intolerance of the tastes of others that suggest this egalitarian public was perhaps less well regulated than Weber suggests. ${ }^{32}$ Furthermore, it remains unclear whether the drive to specialization necessitated an abandonment of miscellany. In literary studies in particular, its ongoing importance into the nineteenth century has been the subject of some attention in recent years. Andrew Piper and Jonathan Sachs have argued for the importance of the 'miscellaneous and non-singular' to Romantic-period literary life. ${ }^{33}$ And David Stewart, studying early-nineteenth-

29 Peter Burke, Popular Culture in Early Modern Europe (London: Temple Smith, 1978), 270.

30 Anthony Ashley Cooper, Earl of Shaftesbury, Characteristicks of Men, Manner, Opinions, Times, 2 vols (Gloucester, MA: Peter Smith, 1963), 2:159.

31 Weber, The Great Transformation, 16.

32 See for example the disagreements at the Anacreontic Society as outlined in Ian Newman, 'Civilizing Taste: "Sandman Joe", the Bawdy Ballad, and Metropolitan Improvement', EighteenthCentury Studies 48/4 (2015): 437-56, 448.

33 Andrew Piper and Jonathan Sachs, 'Introduction: Romantic Cultures of Print-From Miscellaneity to Dialectic', Romanticism and Victorianism on the Net 57-58 (2010). doi: 10.7202/ 1006508ar. 
century magazines, has suggested not an abandonment of the miscellaneous, but a shift from a model 'based on the diversity of its readers' interests' to a 'miscellaneity based on the diversity of [the magazine's] readers'. ${ }^{34}$ Rather than an abandonment of the miscellaneous, then, the transformation in taste can be seen as a shift in cultural priorities, as miscellany remains an active form of organization, but one that becomes increasingly marginalized, operating only within restricted limits, and now measured against the growing cultural power of the specialized. In this volume, Jim Davis and Susan Valladares both provide accounts of the fate of miscellany in the generation following Dibdin, in the work of his sons Thomas and Charles the Younger respectively. Both discover that the kinds of varied entertainment for which Dibdin the Elder was known were not abandoned by his sons, but encountered greater obstacles as miscellaneous cultural forms increasingly deviated from the kinds of artistic production to which cultural capital was attached.

All the same, it is unquestionably the case that under the regime of miscellany, audience members encountered a much wider variety of genres and forms than was common under the regime of specialization. While this does not fully explain the extraordinary diversity of Dibdin's career-his forays into new forms and different media were often commercially driven, motivated as much by his fluctuating fiscal fortunes as by artistic considerations - the eighteenth-century culture of miscellany helps us understand the mentalities that made such variety within a single career conceivable. Moreover, the orientation of the miscellaneous to accommodating a wide variety of tastes had important consequences for the way eighteenth-century artists conceived of the communities to which they belonged.

\section{DIBDIN'S NETWORKS}

We have suggested the need to resist the narrative of specialization in The Professional Life, in so far as it charts the evolution of Dibdin from a jack-of-alltrades to a professionalized songwriter. In the light of his late prose works-the novels, the Musical Mentor, the accounts of his tours, and The Professional Life itself - the trajectory of Dibdin's increased specialization is hard to sustain. But the parallel narrative arc of socially embedded collegiality transforming into individual, self-sustaining performance has at first glance a much greater ring of truth. Dibdin's early career is marked by a series of fruitful collaborations, most famously his productive writing partnership with Isaac Bickerstaff, which produced a series of comic operas including Love in the City (1767), The Padlock (1768), Lionel and Clarissa (1768), The Captive (1769), The Ephesian Matron (1769), The Recruiting Sarjeant (1770), He Would If He Cou'd (1771), and The Sultan; or, A Peep into the Seraglio (1775). This highly fruitful collaboration was aborted in

\footnotetext{
34 David Stewart, Romantic Magazines and Metropolitan Literary Culture (Basingstoke and New York: Palgrave Macmillan, 2011), 19.
} 
1772, when Bickerstaff fled to France in order to escape a charge of sodomy, at the time a capital offence. ${ }^{35}$

After the association with Bickerstaff ended, Dibdin began to take sole responsibility for both the music and librettos to his works, but the theatre was an inherently collaborative medium, and getting his works performed involved maintaining relationships with a wide variety of theatre managers, actors, musicians, and performers—something that Dibdin found notoriously difficult. Bickerstaff and Dibdin's early works were performed at Covent Garden, where he worked with John Beard and George Colman, but after a dispute with Colman in 1768 Dibdin signed a seven-year agreement with David Garrick at Drury Lane, while simultaneously under contract to produce works for Ranelagh Gardens. At the end of the seven-year arrangement Dibdin moved on again, taking his opera The Waterman (1774) to Samuel Foote's Haymarket Theatre and writing a puppet play, The Comic Mirror, which included an attack on Garrick. After a two-year period in France, Dibdin returned to London and produced short pieces and harlequinades for both Foote at the Haymarket and Thomas Harris at Covent Garden, and wrote regularly for Thomas King at Sadler's Wells. But his relationships with the theatre managers were getting increasingly strained, so Dibdin came up with a plan to 'throw off [the] leading strings' of the major theatres and set up on his own. ${ }^{36}$ The result was the extraordinary Royal Circus, discussed by Michael Burden in Chapter Three. This was a complex multimedia operation, capitalizing on the popularity of Astley's equestrian events, and combining feats of horsemanship with some of the operas that Dibdin had written for Thomas Harris, and a children's theatre, intended to train young actors for the stage. It required Dibdin to obtain the lease on the land near Blackfriars Bridge, to build a suitable theatre, to hire teachers and singing and dancing instructors, and to oversee the education and board of the sixty children who enrolled in the school. It also required Dibdin to collaborate with Charles Hughes, a 'strong man' who had previously worked with Astley and was in charge of the equestrian entertainments, and Giuseppe Grimaldi, father of the famous clown Joseph, a well-known harlequin in his own right, who was put in charge of the dancing. After a successful first season in 1782, the Circus failed, in part because of disputes over licensing, precipitated, Burden suggests, by the inability of the proprietors to work together in a venture that demanded collaboration. ${ }^{37}$ In The Professional Life, Dibdin claims that the Circus 'was the child of my own fancy. I projected it; I fabricated it; I supplied it with materials'. ${ }^{38}$ It is thus an important transition from the collaborative (or, in Dibdin's view, despotic) theatrical world he had previously inhabited to the more independent

35 The Sultan was acquired by the actress Fanny Abingdon, who was in correspondence with Bickerstaff while he was in exile and brought it to Drury Lane with the help of Garrick. See Judith Milhous and Robert D. Hume, 'Isaac Bickerstaffe's Copyrights-and a Biographical Discovery', Philological Quarterly 83/3 (2004): 259-73.

36 Life, 2:103.

37 Burden's account challenges Burwick's suggestion that the ribald nature of Dibdin's burlettas precipitated the licensing problems. See Burwick Playing to the Crowd, 14, 176-8.

38 Life, 2:115. 
projects he pursued thereafter. It is clear, however, that this child of Dibdin's fancy required a great deal of intensive collaborative work, not only with the 'the leech, Hughes' and 'the serpent, Grimaldi', 39 as he calls them in The Professional Life, but with magistrates, proprietors, architects, builders, actors, educators, and children.

Even in his later, more self-sustaining ventures, such as the Sans Souci, his journalism, novel-writing, and publishing ventures, the process of bringing his original concept to fruition would require much help and assistance. We catch a glimpse of this in a case that was brought before the Public Office in Bow-Street in October 1792, which Dibdin attended 'with several persons employed by him' at the Sans Souci. The case involved a street brawl which took place between Dibdin's employees and the employees of the wine merchant next door, after the contents of a tub of water that had been used for cleaning bottles were discharged onto the head of Dibdin's wife. An argument ensued, leading to personal abuse, which ended with 'an attack on Mr. Dibdin's people, some of whom were severely cut in the face'. ${ }^{40}$ The report does not mention what the assigned tasks of each of Dibdin's people were, and it is vague about numbers, but it is clear that Dibdin's solo performance required a significant staff, a fact that he erases from the record of his 'one-man' triumphs in The Professional Life. ${ }^{41}$

As well as these professional collaborations, the orientation of Dibdin's writing is always outwards, always turned towards his audience, anticipating and compensating for his own fame, notoriety, and reputation. Despite his chronological overlap with the development of literary Romanticism, his sensibility is quite distinct from the creative genius who might seek inspiration or solace from lyrical contemplation; Dibdin is, by contrast, constantly aware of himself as part of a dynamic social system, and thoroughly embedded within its workings.

The social worlds to which Dibdin belonged might be glimpsed by considering Dibdin's relationship with Garrick in more detail. In The Professional Life, Dibdin presents Garrick as stifling, keeping him busy with projects that would never see the light of day in order to prevent him writing for his rivals. Yet it is clear that for a time Dibdin and Garrick were very close. Garrick was godfather to Dibdin's illegitimate son, Thomas John Dibdin, whose mother was Harriet Pitt, a dancer and actress who worked at both Drury Lane and Covent Garden. Garrick gave Thomas Dibdin his stage debut at the age of four, when he played Cupid alongside Sarah Siddons's Venus in Garrick's Jubilee-a play originally written in 1769 to mark the bicentenary of Shakespeare's birth and part of a festival of bardolatry spearheaded by Garrick, for which Dibdin wrote much of the music. This was a densely networked theatrical and artistic world, where the duopoly of the patent theatres guaranteed a circumscribed number of artists and performers whose connections with one another might range across personal and professional domains of experience-exposing the difficulties inherent in Dibdin's attempt to separate out his 'professional life'. These networks might quickly be expanded outwards

39 Ibid., 2:111. $\quad 40$ Diary or Woodfall's Register (19 October 1792).

41 For a separate incident suggestive of the roles that Dibdin's wife and daughter played at the Sans Souci, see Fahrner, 147. 
beyond obvious members of the theatrical world to include a much wider sphere of cultural production. Dibdin makes a cameo appearance in Boswell's Life of Johnson, when he writes the music to a song, 'A Matrimonial Thought', 'which Mr. Garrick had a few days before procured to be set to music by the very ingenious Mr. Dibdin'. ${ }^{42}$ Garrick was, of course, a close friend and confidante of Johnson and a member of his literary club, whose highly select membership consisted of great men from the world of art, politics, and the theatre, including Edmund Burke, Oliver Goldsmith, and Joshua Reynolds. While Dibdin did not possess sufficient cultural capital to be invited to join such an elite group of tastemakers, he occupied a position immediately proximate to it through his professional connection and friendship with Garrick.

A salient comparison might be with Charles Burney. Unlike Dibdin, who always remained at the fringes of cultural legitimacy, Burney was able to gain direct access to Johnson's immediate circle. Like Dibdin, Burney was another musician of humble origins who had risen rapidly in the public's estimation and in social status through a combination of astute networking and ambitious publication projects. The celebrated success of Burney's four-volume History of Music (1776-89) may well have been the chief inspiration for Dibdin's five-volume Complete History of the English Stage (1800), while Burney's accounts of his musical tours through Europe bear distinct parallels to Dibdin's The Musical Tour of Mr Dibdin (1788) and Observations on a Tour (1801-2). Burney represented the new possibilities opened up by the expansion of eighteenth-century print culture for individuals to achieve fame and status through publication-opportunities that Dibdin also seemed keen to exploit. Ultimately, however, Burney's success proved more solid, secured notably through institutional recognition (Burney was awarded a doctorate in Music by the University of Oxford in 1769 and became a fellow of the Royal Society in 1773) — whereas Dibdin claimed, in a turn of phrase that was perhaps deliberately ambiguous, to have declined an offer from Professor of Music Philip Hayes to take a doctorate at Oxford. ${ }^{43}$ Dibdin's failure to achieve institutional recognition may be another indicator of the shifting relationship between specialist and miscellaneous cultural production, highlighted also by Dibdin's peripheral relationship with the Johnson circle: for each of the tastemakers that gathered around Johnson at the Streatham home of Hester Thrale_-including Burney—had achieved distinction in a particular specialized field of cultural production. Dibdin, firmly attached through financial necessity to the miscellaneous means of operating in the commercial entertainment world, could not fit easily into the more specialist model of the Streatham set. Always at the periphery of the kinds of cultural authority Burney was able to acquire, an anxiety over the precariousness of fame and his own social status became a continual leitmotif of Dibdin's writing and career strategies.

42 James Boswell, The Life of Samuel Johnson, ed. R. W. Chapman (Oxford: Oxford University Press, 1980), 430

43 Musical Tour, 60. 
At the other end of the social spectrum, Dibdin's popularity might be judged by his remarkably strong presence in the more often anonymous song slips and broadsides sold by ballad singers. The Bodleian's Broadside Ballads Online, for example, lists 324 sheets with Dibdin songs, (compared with six by Braham, eleven by Colman the Younger, eight by Hook, one by Shield, and two by Storace, probably the next-best-known songwriters of the day). Some of these are duplicates, but it would also be surprising if there were not many other songs by Dibdin in this collection that have not been attributed. These texts are notoriously difficult to date; nevertheless, it is clear that even those songs written much earlier appear as broadside ballads only occasionally before 1790 , though they gain in popularity throughout the 1790s — as Harriet Guest describes in Chapter Eight — and into the nineteenth century. It should be acknowledged that the Bodleian broadsides, the largest collection of such material currently available, is particularly strong in ballads printed by Pitts, Catnach, and Jennings in the 1790s-1820s, and relatively weak in holdings from the mid-eighteenth century, potentially accounting for the strong presence of Dibdin towards the end of his career. Yet the collection's evidence corroborates Francis Place's assertion that Dibdin's sea songs were among those loyalist ballads that replaced bawdy and potentially seditious balladry in London streets after the French Revolution. ${ }^{44}$ The popularity of Dibdin's songs in this period is further suggested by the categorization of the three-volume Universal Songster, a publishing phenomenon of 1825-6, according to which songs were variously 'Amatory', 'Bacchanalian', 'Sporting', and so on—or 'Dibdins', a singling out accorded to no other writer. ${ }^{45}$ The larger number of Dibdin songs in the Bodleian ballad collection towards the end of Dibdin's career also coincides with Dibdin's reinvention of himself as primarily a writer of songs in a popular vein, rather than as an actor, operatic composer, or theatre manager and impresario.

Dibdin's songs were printed without his permission by all of the important London and regional ballad printers of the early nineteenth century, adding no doubt to Dibdin's frustration that he was not adequately remunerated for his songwriting efforts, despite their widespread popularity from the elite membership of Johnson's club to the street singers of popular tradition. Furthermore, in spite of the narrative of specialization and segregation suggested by Burke and Weber, Dibdin provides evidence of a popular songwriter and performer whose work was known and cherished simultaneously by elite tastemakers and street musicians well into the nineteenth century.

In addition to broadside ballads, Dibdin's songs, as Guest discusses, were reproduced in other, more expensive formats, such as the large quarto sheets produced by Laurie and Whittle (best known for their maps and charts), and Samuel William Fores (known for publishing visual satires by Gillray and Rowlandson). ${ }^{46}$ Here

44 BL Add. MSS 27825 fo. 141. Francis Place, 'Collections relating to Manners and Morals', vol. 1, part B 'Specimens of Songs Sung About the Streets of London'. See Cox Jensen, Chapter Seven in this volume.

45 George and Robert Cruikshank, The Universal Songster, or, Museum of Mirth: forming the Most Complete, Extensive, and Valuable Collection of Ancient and Modern Songs, 3 vols (London, 1825-6).

46 See Harriet Guest, Chapter Eight in this volume. 
Dibdin's words would take up half of a large sheet, with often beautifully coloured decorative engravings occupying the other half. While the songs themselves are often the same as those reproduced in song slips, Fores and Laurie and Whittle catered to a very different clientele.

Taking these song sheets as evidence, we can trace Dibdin's networks among those places where his works appeared and where they were known. Dibdin's networks might move beyond the professional relationships he evidently had among the theatrical world and concert-going crowd, and might be expanded to include the hawkers who performed his songs in public, the men and women who would hum his tunes as they went about their daily routines, the publishers and printers of his songs (posthumously or otherwise), such as Catnach, Pitts, John Marshall of Newcastle, Fores, and Laurie and Whittle, and the engravers such as Isaac and George Cruikshank, who illustrated Dibdin's works for Laurie and Whittle; and even, as Nicholas Grindle suggests in Interlude Three, to artists such as George Morland, who produced fine-art paintings taking inspiration from Dibdin's songs.

In this volume we regard Dibdin as a hub around which the moving parts of late Georgian cultural production revolved. In the following pages we encounter a wide range of performance spaces and print venues ranging from the theatres at Drury Lane and Covent Garden, through Ranelagh Gardens, Sadler's Wells, and the Royal Circus, to singing on board ships and in elegant Regency parlours; from broadside ballads and graphic satires to newspaper journalism, mezzotint engravings, painting, and decorative pottery. Dibdin's importance lies in his ability to make visible the connections between various kinds of cultural production; he provides a model for thinking about the machinery of late Georgian culture as a system of interconnected parts, reliant upon one another, and moving, if not in perfect synchrony like welloiled clockwork, at least with an awareness of movements in other, seemingly distant parts of the same complexly networked mechanism.

This book is intended to shed light on the various aspects of the machinery of late Georgian culture and the connections between them. It is divided into three parts, interspersed with 'interludes' - shorter informative pieces that draw on information presented in the full-length chapters but expand our perspective in new, suggestive directions. The first part, 'Dibdin in Context', attempts to unshackle Dibdin from his Victorian refashioning and place him back into the eighteenthcentury environments within which he worked. This begins in Chapter Two with Felicity Nussbaum's analysis of Dibdin's representations of race, ranging from his celebrated blackface performances as Mungo in The Padlock (1768) to his oriental entertainments The Seraglio (1776) and The Magic of Orosmanes (1785). Nussbaum considers what it means to turn the serious subject of slavery into light-hearted entertainment. In Chapter Three Michael Burden discusses one of Dibdin's more extraordinary ventures, the Royal Circus, which opened in 1782. Burden suggests that many of the artistic decisions of running a miscellaneous theatre of this kind can be attributed to the need to distinguish oneself from the competition, especially in the case of the Royal Circus from Philip Astley's hugely successful equestrian entertainments. In our first interlude Katie 
Osborn discusses the connection between the worlds of song and poetry, situating Dibdin alongside rural labouring-class poets, with particular emphasis on Robert Bloomfield. Osborn interrogates the intersection of metropolis and countryside by locating these two writers' texts within their working practices, their music, and their engagement with particular London audiences, and provides a reading of the rustic and the citizen that is knowing, even-handed, and modern.

Dibdin's work as a journalist is the subject of Chapter Four. David O'Shaughnessy provides a detailed assessment of the symbiotic relationship of the theatre and newspaper publishing in the 1780s, arguing that in his newspaper The Devil Dibdin accused both theatres and newspapers of abandoning their responsibilities to the public sphere in favour of mutually beneficial profits. O'Shaughnessy's situating of this periodical literature within both a political climate and a metropolitan sphere of sociability enriches our understanding of the interrelation of networks, individuals, and issues operating on and within the entangled world of press and theatre.

The 1790s was the decade in which Dibdin achieved his greatest commercial success with his solo entertainments held at his Sans Souci theatres. But as David Kennerley shows in Chapter Five, commercial success came with its own drawbacks as the press began to accuse Dibdin of plagiarizing from his former collaborator Isaac Bickerstaff. Kennerley discusses the series of libel trials that ensued, exposing the pronounced effect of celebrity upon both contemporary theatrical and political culture, and reassesses Dibdin's widely influential brand of loyalism in this most turbulent decade in British politics. In Chapter Six Judith Hawley discusses the rage for private theatricals after which Dibdin named his first Sans Souci show. Hawley sheds light on the cross-class craze for private theatricals by bringing them into dialogue with the world of the professional theatre through Dibdin, showing how the faux-'private' actions of both Dibdin and amateur dramatics reflected the irrevocable destabilization of the patent theatres' monopoly on spoken drama. Our first part concludes with Nicola Pritchard-Pink's interlude, which extends this consideration of Dibdin's intersection with realms of amateur performance by considering Jane Austen's music collection, in which Dibdin's songs feature prominently. These, with their bawdy comedy, political, and social satire, and martial, masculine themes, are far removed from the musical diet prescribed for young ladies of Austen's rank by conduct writers, including Dibdin himself in the Musical Mentor. Pritchard-Pink presents domestic musical performance as a means by which women could express themselves and participate in the world beyond the bounds of home, family, and conduct-book femininity.

Without abandoning the contextual work offered in the first part, Part Two, 'Songs in Focus', shifts the attention towards discussions of particular songs. In Chapter Seven Oskar Cox Jensen discusses 'True Courage', from its 1798 composition to calls for its revival in 1900, taking in its performance, reception, dissemination, appropriation, and reinvention. A close musical and lyrical reading is tied to those chronological contexts, and informed by the views and cultural practices of those involved-Dibdin, other singers, audiences, and later interpreters 
of 'True Courage' - shedding new light on the mentalities and habits of its day. In Chapter Eight Harriet Guest similarly takes a single song, here Dibdin's 'A Voyage to Margate', better known as 'The Margate Hoy', and examines its social resonances, but with an emphasis less on its performances than its print history. Guest's chapter provides a fascinating study of the mutually reinforcing domains of song and visual culture, from slip songs and street ballads, through graphic satire and finely produced drolls, to aspirational mezzotint engravings based on oil paintings by George Morland. Developing one aspect of Guest's argument, in our third interlude Nicholas Grindle examines in greater detail the relationship between Dibdin, Morland, and John Raphael Smith, who published numerous luxury prints based on Dibdin's songs. Grindle considers the implications of the appropriation of a popular musical tradition by the world of fine art, and provides a compelling account of the overlapping worlds of visual culture, the theatre, and musical entertainment by examining the clubs and societies in which their leading figures mingled.

The final part of the volume considers Dibdin's legacies in the nineteenth century, initially by examining the work of his two sons, Charles Isaac Mungo Dibdin and Thomas Dibdin. In Chapter Nine Susan Valladares considers the fate of the miscellaneous or mixed medley performance in Charles Dibdin the Younger's Sadler's Wells theatre after 1814, and compares it to his poetic romance, Young Arthur (1819), which, while enthusiastically received by some, was too much of a 'medley' to satisfy others. Dibdin's younger son Thomas is the subject of Chapter Ten, in which Jim Davis reveals both change and continuity in expectations of dramatic authorship and theatrical practice in the early nineteenth century. Davis explores the collaborative nature of Thomas Dibdin's writing, arguing that his scripts were not finished literary texts, but raw materials designed to be fully realized only in performance, as celebrated actors brought their own creative contributions to their roles to suit their stage personas. Yet, at the same time, the gathering forces of specialization and the privileging of the author as the hallmarks of legitimate cultural authority were beginning to create new hierarchies of theatrical production, genres, and styles, highlighting the contrasts between the era of Dibdin the Elder and that of his sons. The volume concludes with a reassessment of perhaps the most familiar Dibdin, the writer of sentimental sea songs who was beloved throughout the nineteenth century. Focusing on Dibdin's posthumous reception, Isaac Land examines the moral and rhetorical difficulties of repackaging Dibdin's works for a Victorian sensibility. He explores the specifics of mid-century concert culture previously highlighted by Weber and Derek Scott as central to changes in nineteenth-century taste and programming, and considers the way nostalgia reveals the relationship between new naval technologies and the songs, people, and language of a remembered Napoleonic 'golden age'- to which Dibdin proves to have been central in the Victorian imagination.

Individually, these chapters contribute valuable knowledge and analysis of Dibdin's life, work, and reputation. Collectively, in the connections between the chapters, they offer something much more: insight into the capacious nature of late Georgian culture, in which a song can resonate across boundaries of class and gender; where a performance can begin on the stage of Covent Garden then insert 
itself into heated debates about the slave trade decades later; and where a single individual can be an actor and composer in the morning, a journalist in the afternoon, a novelist in the evening, and the saviour of the Royal Navy after dinner. To acknowledge the connections between the wide-ranging and often dissimilar resonances of Dibdin's miscellaneous career is not to argue for a totalizing theory of late Georgian culture, but to recognize the necessity of an interdisciplinary approach to cultural production; one that does not eschew disciplinary expertise, but is aware of the blind spots of specialization, and mines these for what they can reveal about those areas that fall beyond our usual disciplinary limits. This volume, then, represents a collaborative study, gathering together experts in the fields of art, history, literature, music, and theatre, who have worked together in a coordinated attempt to map out a complex terrain of cultural production whose contours could not adequately be grasped from within a single discipline. Part of the reason that Dibdin has so long been overlooked is precisely because of the larger cultural movement towards specialization that began in his day and which continues to shape our current academic environment, a regime of specialization which no doubt has considerable benefits, but which also has limitations. After several decades in which the call to interdisciplinarity has become commonplace, the time is ripe to offer a fuller consideration of Dibdin's varied practice and to recognize the challenges the art of miscellany poses to our modes of enquiry. 
Comp. by: Kalaimathy Stage : Revises 1 ChapterID: 0003304477 Date:6/10/17

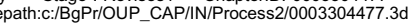

OUP UNCORRECTED PROOF - REVISES, 6/10/2017, SPi 


\section{PART I}

\section{DIBDIN IN CONTEXT}


Comp. by: C. Vijayakumar Stage : Revises1 ChapterID: 0003304478 Date:9/10/17

ime:13:33:12 Filepath:d:/womat-filecopy/0003304478.3D

OUP UNCORRECTED PROOF - REVISES, 9/10/2017, SPi 


\title{
2 \\ 'Mungo Here, Mungo There' Charles Dibdin and Racial Performance
}

\author{
Felicity Nussbaum
}

\begin{abstract}
Slavery in its many forms is ubiquitous in Charles Dibdin's later-eighteenthcentury musical entertainments. The Padlock (1768), in which Dibdin played the starring role as the blackface house servant Mungo, is the most notable, but among the other comic musical dramas he contributed to as playwright and/or composer are The Captive (1769), The Sultan, Or, A Peep into the Seraglio (1775), The Blackamoor Wash'd White (1776), The Seraglio (1776), and The Magic of Orosmanes; Or, Harlequin Slave and Sultan: A Pantomime, Drawn from the Arabian Legends (1785). For Dibdin, captivity, servitude, and chattel slavery become laughing matters as the victims rail against their lack of freedom with ludic dialogue and catchy tunes. Incorporating the musical score into discussion of the printed texts of these entertainments makes analysing their performances richer, yet also more complicated. Dibdin's apparently innocuous popular entertainments are designed, I argue here, to reflect without resolving the tensions surrounding national issues of slavery, social class, and imperial expansion that troubled Britain's image of itself as the bastion of liberty and equality.

Though several blackface comic characters, often sans dialogue, appear earlier in the century, Charles Dibdin was the first British actor to play a fully developed comic blackface role impersonating an Afro-Caribbean slave in Isaac Bickerstaff's The Padlock, derived from Miguel de Cervantes' El celoso extremeño or 'The Jealous Husband' (1613), set in Salamanca. The wildly popular role became virtually identical with Dibdin, for he not only starred in the play but also composed the music: both the overture and piano reduction of the entire score are extant. ${ }^{1}$ The advertisement, uniting the cause of African slaves with European women, notes the play's inspiration from Matthew Prior's poem 'An English Padlock' (1705) in which the only fool-proof padlock is the one clamped on a woman's mind. Another adaptation of Cervantes' tale, Eliza Haywood's The Padlock: Or No Guard Without Virtue (1728), features a lame, blind, and deformed black slave as a

1 Though Garrick received $£ 1,700$ for The Padlock, Dibdin claims he was given only $£ 45$. In Life, $1: 71$, he writes, 'In thirteen years, nearly three sets of the Padlock had been worn out. I made a set of plates, at this time, take off about three thousand five hundred impressions; so that an estimate may be easily made of the immense profit it yielded.'
\end{abstract}


young wife's adulterous lover. ${ }^{2}$ Haywood reimagines the implications of Prior's poem for she enjoins men 'to rule rather by Choice than Compulsion'. Applying the poem to the play, Bickerstaff transformed Cervantes' black eunuch into the blackface Mungo, extending the allusion to the lock on a slave's collar. It is worth noting that The Padlock debuted about six months after the 27 March 1768 Montserrat slave rebellion, which may have triggered fears of insurrection. ${ }^{3}$

Dibdin joined the Drury Lane theatre corps and brought playwright Bickerstaff along with him. Their collaboration, The Padlock, is an opera buffa, a send-up of serious opera. The light comic form was probably transported from Naples to England in the late Restoration and early eighteenth century, perhaps via French opéra comique. ${ }^{4}$ From 1766 to 1772 the number of opera buffa performances in London outpaced those of opera seria by three to one. ${ }^{5}$ The evening's entertainment included a main-piece along with the comic opera. The one- or two-act comic operas represent the ordinary people at their centre as risible. The libretto and dialogue are mundane, sometimes vulgar, and frequently peppered with dialect and colloquialisms. The Padlock features an attractive young soprano lead, her ardent suitor who sings tenor, a baritone outsider, Mungo, who offers ironic commentary, and a comic bass who often intones ludicrous rapid-fire nonsense. The impediment to the union of the young lovers is happily resolved in the ensemble's rousing finale.

The Padlock premiered on 3 October 1768 and enjoyed fifty-four performances, followed by more than a hundred stagings over the next three years: from 1768 to 1776, performances numbered 142 at Drury Lane and seventy at Covent Garden. ${ }^{6}$ Its frequent productions in England extended into the next century when Ira Aldridge, the first black actor on the British stage, renewed the popularity of Mungo with a sympathetic portrayal of the role. In America, twenty-six known performances took place in New York, Philadelphia, and Baltimore, from 29 May 1769 until the theatres closed in 1774 in anticipation of the American War. In the late eighteenth century The Padlock was the most regularly performed afterpiece in Montego Bay and Kingston, Jamaica; ${ }^{7}$ it played in St Petersburg (1771) and Vienna (1853), and in parts of the British Empire including Madras (1788),

2 Haywood's novella recalls the frame tale of The Arabian Nights (English translation as Arabian nights entertainments, London, 1707-17). See also Toni Bowers, Force or Fraud: British Seduction Stories and the Problem of Resistance (Oxford: Oxford University Press, 2011), 243-7.

3 Prithi Kanakamedala, 'Staging Atlantic Slavery', in Swindells and Taylor, Handbook of the Georgian Theatre, 673, mentions the Montserrat rebellion.

4 After Goldoni and Galuppi's Il filosofo di campagna (1761), opera buffa became a part of every season, according to Michael Burden, 'Opera in the London Theatres' in Moody and O'Quinn, Companion to the Theatre, 211.

5 Ian Woodfield, Opera and Drama in Eighteenth-Century London: The King's Theatre, Garrick, and the Business of Performance (Cambridge: Cambridge University Press, 2001), 77-8.

6 Roger Fiske, English Theatre Music in the Eighteenth Century (2nd edn, Oxford: Oxford University Press, 1986), 352; John R. Oldfield, Popular Politics and British Anti-slavery: The Mobilisation of Public Opinion Against the Slave Trade, 1787-1807 (Manchester: Manchester University Press, 1995); John R. Oldfield, "The Soft Ties of Humanity": Slavery and Race in British Drama, 1760-1800', Huntington Library Quarterly 56/1 (1993): 1-14, 9.

7 Errol Hill, The Jamaican Stage 1655-1900 (Amherst: University of Massachusetts Press, 1992), 79. The Padlock was performed at least ten times between 1777 and 1813 along with a comedy or tragedy and afterpiece. 
Calcutta (1789), Cape Town (1815), and Bombay (1820). ${ }^{8}$ In addition it was adapted into a popular marionette and puppet show performed at local fairs.

In The Padlock's plot the wealthy sixty-year-old Don Diego awards the impoverished family of his young fiancée Leonora 4,000 pistoles in exchange for her hand. ${ }^{9}$ He fears, however, that the captive ingénue will be unfaithful. Don Diego's opening song ridiculously parodies Hamlet's soliloquy: 'Thoughts to council-let me see- / Hum — to be, or not to be / A husband, is the question. A cuckold! Must that follow?' (1.1). By the second verse the old man decides that padlocking the house during his absence will ensure her virginity (though she has earlier rendezvoused with a disguised Leander at Mass), and he sets off to arrange the nuptials. An allegro tempo suits his frenzied worry about being cuckolded, and he rushes off to a presto accompaniment.

The West Indian servant Mungo and the old maid Ursula are entrusted with the keys to Don Diego's home, though not the crucial padlock key, during his visit to Leonora's parents. The beleaguered Mungo, with whom the knowing audience sympathizes, boldly insults his master and points out the inequities of slavery. Mungo's blackface burlesque performances, from the original Padlock through to the abolitionist epilogue added in the 1780s, mediated the concept of England as both 'a white metropole and abolitionist empire of liberty', as Jenna Gibbs has pointed out. ${ }^{10}$ As with any caricature, however, the Mungo character has fractured meanings. The songs follow James Beattie's description of caricature in his 'Essay on Laughter' (1776) in provoking laughter because of the 'uncommon mixture of relation and contrariety, exhibited, or supposed to be united, in the same assemblage'. ${ }^{11}$ As both servant and slave, Mungo is humanized as a suffering servant but mocked and beaten because he distorts the language, is alleged to be lazy, and contests Don Diego's authority.

A range of readers have argued that popular entertainments such as harlequinades promoted the abolitionist cause, though Jeffrey Cox has aptly noted that Mungo is both 'the butt of the farce' and a sympathetic voice of resistance, especially later in the century. ${ }^{12}$ But the much-caricatured character enables fluid responses towards slavery depending upon the time, place, and circumstances of its representation. On the one hand, Dibdin's depictions may be understood to provoke laughter that diffuses the institution's potential disruptive threat. At the

8 Tasch, The Dramatic Cobbler, 159.

9 Isaac Bickerstaff, The Padlock. A Comic Opera (London, 1768). All subsequent citations are to act and scene in this edition.

10 Jenna M. Gibbs, Performing the Temple of Liberty: Slavery, Theatre, and Popular Culture in London and Philadelphia, 1760-1850 (Baltimore: The Johns Hopkins University Press, 2014), 63.

11 James Beattie, Essays on the Nature and Immutability of Truth, in Opposition to Sophistry and Scepticism, 2 vols (Dublin, 1778), 2:399.

12 David Worrall, Harlequin Empire; Race, Ethnicity, and the Drama of the Popular Enlightenment (London: Pickering \& Chatto, 2007); Kathleen Wilson, 'Blackface Empire: Love, Theft, and Subversion in British Domains', in Kathleen Wilson, Strolling Players of Empire: Theater, Culture and Modernity in the British Provinces, 1720-1820 (Cambridge: Cambridge University Press, 2016); and Jeffrey N. Cox (ed.), Slavery, Abolition and Emancipation: Writings in the British Romantic Period, 8 vols (London: Pickering \& Chatto, 1999-), 5:xv. 
same time, the actor/composer may well have been pursuing a savvy commercial strategy in playing both sides of the debate and allowing his representations to resonate with audiences who held unformed or unsettled opinions.

The caricatured language of Mungo, whose status rests somewhere between servant and slave, is believed to be the earliest attempt to represent West Indian dialect on the British stage. ${ }^{13}$ Dibdin claims that he first created the role of Mungo for the Irish actor and singer John Moody, who brought Negro dialect, as it was called, from his West Indian travels. Moody's triumph as the black servant Lovel in the non-musical farce High Life Below Stairs (1759) made him seem the likely candidate to play Mungo, but Dibdin eventually won the coveted singing part and performed it with enormous success. ${ }^{14}$ Dibdin signalled the importance of the character to his career when he named his son, born in the year The Padlock debuted, Charles Isaac Mungo. ${ }^{15}$ The name itself may be an example of black, regional, and rural dialects, for the Oxford English Dictionary indicates that 'mun go' may be a slurring of the phrase 'must go' ${ }^{16}$

As noted above, blackface impersonation in eighteenth-century opera and dance was not without precedent. Musical performance mixed with parodied or mangled language was part of early musica ebraica, which in turn reveals connections to the moresca repertory in Moorish costume of Renaissance pantomime, song, and dance. ${ }^{17}$ Players used burnt cork or carmine to darken their faces. ${ }^{18}$ Blackened characters represented African Moors from the sixteenth century onwards in European operas, ballets, masques, and pageants. ${ }^{19}$ Olivia Bloechl directs our attention to the way early music mediated racial fantasies and later undergirded more fixed, racially marked representations in opera and dance. ${ }^{20}$ Dibdin's Mungo,

13 Fahrner, 57. See also Richard Walser, 'Negro Dialect in Eighteenth-Century American Drama', American Speech 30/4 (1955): 269-76.

${ }_{14}$ See Life, 1:70. Fiske, English Theatre Music, 352-3. Dibdin allegedly made the part too taxing for the Irish actor and singer John Moody, and for Dodd who was next offered the role. Only the overture survives from the original orchestral scoring.

15 Fiske, English Theatre Music, 348-53. Dibdin's son was one of two illegitimate children resulting from his union with Harriet Pitt, a pantomime dancer.

16 See Carlson, 'New Lows'. According to the $O E D$, 'mungo' also describes variously a root plant, a mongoose, or a dog.

${ }_{17}$ Emily Wilbourne, 'Lo Schiavetto (1612): Travestied Sound, Ethnic Performance, and the Eloquence of the Body', Journal of the American Musicological Society 63/1 (2010): 1-43. Moresca similarly mixes parodied language with song and dance, 22.

18 Thomas Leman Rede, The Road to the Stage, or the Performer's Preceptor (London, 1827), 38-9, writes, 'To produce the black necessary for the negro face of Hassan, Wouski, Mungo, or Sambo, the performer should cover the face, neck, and hands with a thin coat of pomatum, or what is better, though more disagreeable, of lard; then burn a cork to powder, wet it with beer (which will fix the colouring matter), and apply it with a hare's foot, or a cloth ... A strong colouring of carmine should be laid upon the face after the black, as otherwise the expression of countenance and eye will be destroyed.'

19 In early forms of ballet, the pantomime dancer wears blackface. Ignatius Sancho titles a set of dances he composes 'Mungo's Delight', an obvious allusion to The Padlock. See Jane Girdham, 'Black Musicians in England: Ignatius Sancho and his Contemporaries', in Reyahn King et al. (eds), Ignatius Sancho: An African Man of Letters (London: National Portrait Gallery, 1987), 115-24.

20 Olivia Bloechl, 'Race, Empire, and Early Music', in Olivia Bloechl, Jeffrey Kallberg, and Melanie Lowe (eds), Rethinking Difference in Musical Scholarship (Cambridge: Cambridge University Press, 2015), 77, 82. 
then, drew upon a history of racial impersonation, although his rendering was extraordinarily novel in its broad appeal.

Blackface at its nascent moment intersects with pantomime in ways that have not yet been thoroughly traced, though both its relation to commedia dell'arte and the presence of blackface in ballet have been noted. ${ }^{21}$ Pantomime's Harlequin, performing most often in half-face black mask, is granted carnivalesque, anarchic, and trickster traits as lord of misrule in a world of slapstick, double entendres, and broad satire. Such a character embraced the mysterious or alien but also tamed it through magic or childlike innocence. ${ }^{22}$

Henry Louis Gates Jr has pointed out that English harlequinades from 1783 to 1870 'contain figures of the black as Harlequin [that] combine both blackness and minstrelsy', a connection that emerges at the end of the eighteenth century and is confirmed a century later (see Figures 2.1 and 2.2). ${ }^{23}$ Like the early harlequin character that John O'Brien has analysed, Bickerstaff's Mungo represented 'the common folk — playful and mischievous, occasionally a petty criminal, articulating desires through the body rather than by speech', though the speaking and singing Mungo differed importantly from the mute harlequin. ${ }^{24}$

Like the harlequin, the basso novo of ballad opera sometimes accompanied himself on lute or guitar, but in Bickerstaff's Padlock, the hero Leander displays his talents on the guitar and teaches Mungo how to play the instrument.

In The Padlock Mungo debuts onstage carrying a hamper and cursing his master for treating him like an animal. In his most famous song, laced with irony, he complains of having to seem grateful even as he heeds his master's every beck and call:

Dear heart, what a terrible life am I led,

A dog has a better life that's shelter'd and fed:

Night and day 'tis de same,

My pain is dere game;

Me wish to de Lord me was dead (1.6).

The shadow of Shakespeare's Othello hovers over The Padlock here and elsewhere. Dibdin's lyrics in this popular song echo those of Roderigo, the Venetian rival suitor for Desdemona, in his description of Othello as a wandering stranger, thus

21 Marian Hannah Winter, The Pre-Romantic Ballet (London, 1974), 81 n.46, cited in Elizabeth Miller Lewis, 'Hester Santlow's Harlequine: Dance, Dress, Status, and Gender on the London Stage, 1706-1734', in Jessica Munns and Penny Richards (eds), The Clothes That Wear Us (Newark: University of Delaware Press, 1999), 90-101.

22 Bent Holm, 'Harlequin, Holberg and the (In)visible Masks: Commedia dell'arte in EighteenthCentury Denmark', Theatre Research International 23/2 (1998): 159-66.

23 In several harlequinades a black slave, transformed into Harlequin, is freed when he marries Columbine, the master's daughter. Henry Louis Gates Jr, Figures in Black: Words, Signs, and the 'Racial' Self (New York and Oxford: Oxford University Press, 1987), 51-8, maintains that the Harlequin's domino presence eventually split into the two central figures of minstrelsy, black and white, Tambo and Bones. The Harlequin's black mask, shaved head, and artificial phallus (later reduced to a sword or magic wand) intimate his origins as an African slave. Harlequin's dress was sometimes patched rags or geometric shapes.

24 John O'Brien, Harlequin Britain: Pantomime and Entertainment, 1690-1760 (Baltimore: The Johns Hopkins University Press, 2004), 132. 


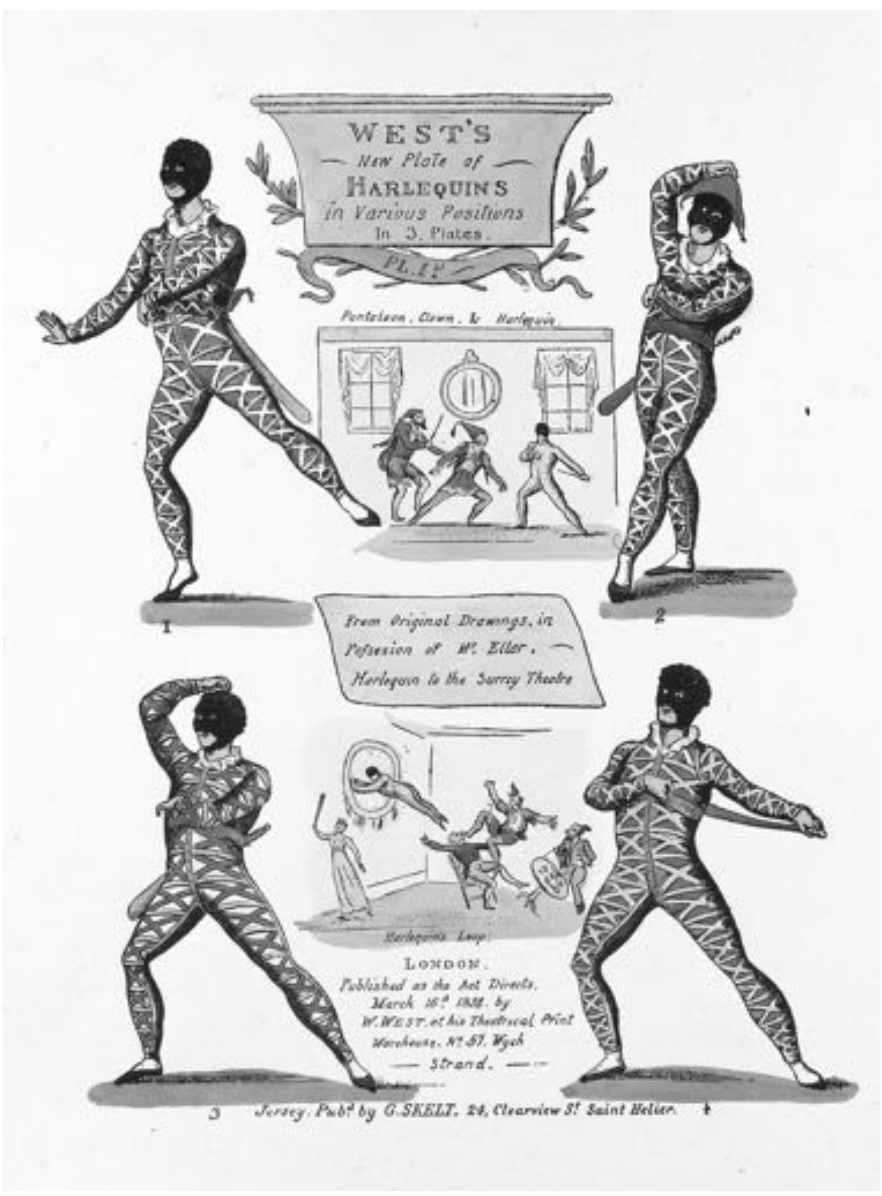

Figure 2.1. William West, West's New Plate of Harlequins in Various Positions. From original drawings, in possession of Mr. Ellor. Harlequin to the Surrey Theatre. London, 16 March 1824. Engraving. Courtesy of Theatre Museum, London. Victoria and Albert Images/The Art Archive at Art Resource, NY.

lending Mungo's words a hint of danger; a parallel innuendo about the threat that the minstrel Leander — also a wanderer and with claims to have been a slave-poses to Leonora may also be implied. Here are Roderigo's lines about the tragic mixedrace couple in Othello:

Your daughter, if you have not given her leave,

I say again hath made a gross revolt,

Tying her duty, beauty, wit and fortunes

In an extravagant and wheeling stranger

Of here and everywhere. ${ }^{25}$

25 Walter Cohen (ed.), 'The Tragedy of Othello the Moor of Venice', in Stephen Greenblatt (general ed.), The Norton Shakespeare (New York: W. W. Norton \& Company, 1997), 2103 n.1, 


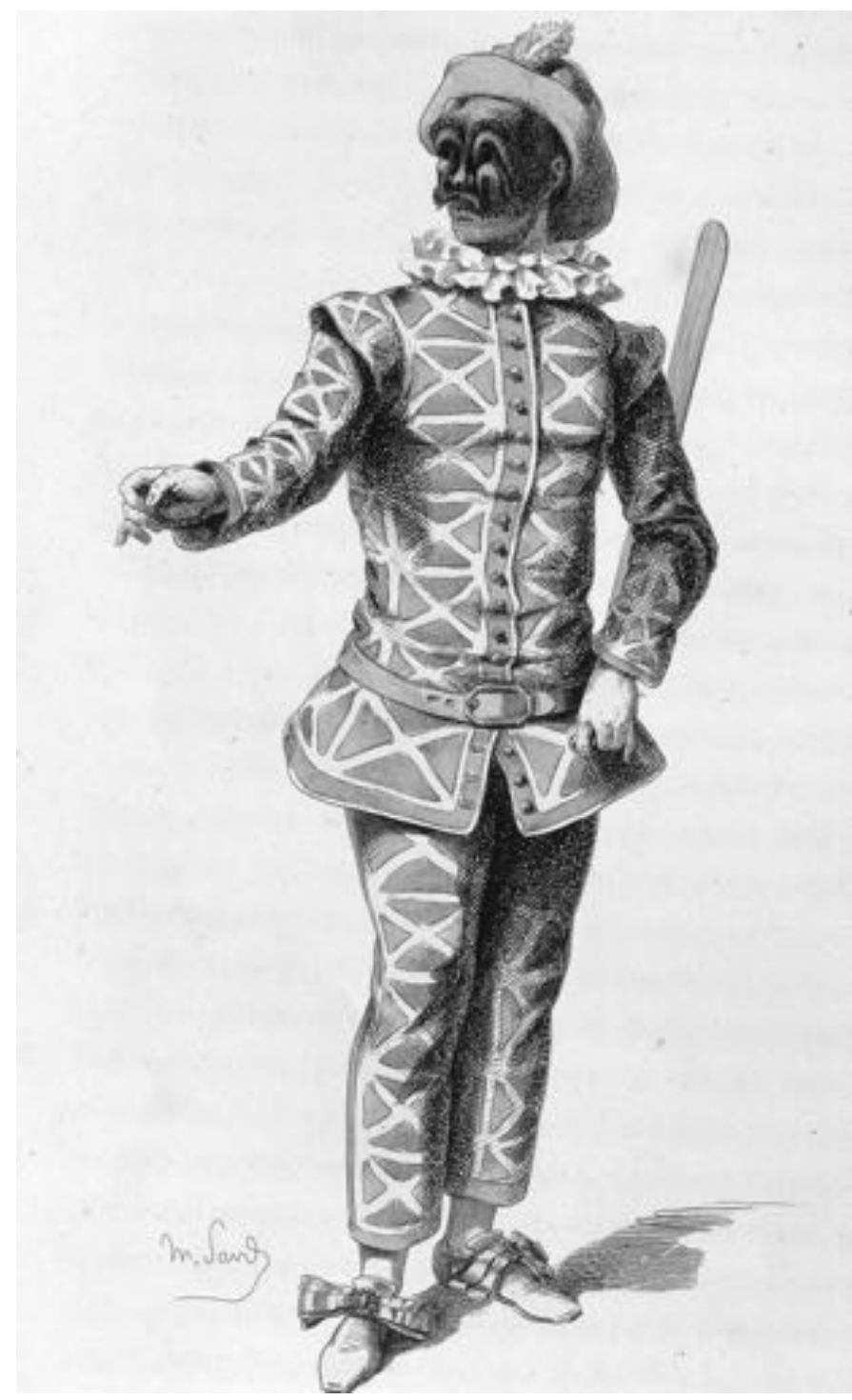

Figure 2.2. Alexandre Manceau, Harlequin or Arlecchino of 1671. Engraving. From Maurice Sand, Masque et bouffons (comédie italienne): texte et dessins (Paris, 1860). Courtesy of Casa Goldoni Museum, Venice. Photographed by Alfredo Dagli Orti/The Art Archive at Art Resource, NY.

Mungo's refrain in The Padlock-'Mungo here, Mungo there, Mungo ev'rywhere'describes his intimidating ubiquity, resembling that of Roderigo although his status as a maltreated overworked servant contrasts to the Shakespearean noble.

parses the line as 'a vagrant and vagabond foreigner (perhaps suggesting a planet wandering off course)'. Thanks to Carla Freccero for mentioning this reference at the Huntington Library Long EighteenthCentury Seminar, October 2014. 
In The Padlock the university student Leander first appears as a lame busker who plays on his feigned disability to win Leonora's affections. He affects to have been held a slave among the Barbary Moors, dissociating slavery from complexion and aligning Oriental exoticism and slavery with the Caribbean. Like Othello, he weaves a spell with a tale, a song of captivity about a Turk's lascivious pursuit of a female Christian slave, Jezabel [sic]. Leander sings an air about a wicked Turk's intent to behead the captive who, like Leonora, is confined by a tyrannical master. In the song the Turk is charmed into reform, just as Mungo and Leonora succumb to the spell of Leander's song. Leander's bribe of wine also tempts Mungo to violate Don Diego's firm directive but, unsuccessful in unlocking the eponymous padlock on the house door, the minstrel Leander, seeming also to present a menacing ubiquity, enters the house and accompanies Mungo as they sing in wild confusion.

When Don Diego returns unexpectedly to find the drunken Mungo along with Leander pursuing Leonora, the rejected old man recognizes his folly in demanding the young girl's hand and agrees to the lovers' marriage. ${ }^{26}$ The long-suffering Mungo, however, bears the blame and is punished with bastinadoes. Leander, having won Leonora, proves that he may be no more open-minded about marriage than Don Diego when, citing Prior's 'English Padlock', he sings, 'Let all her ways be unconfin'd / And clap your padlock on her mind' (1.9). In short, for Dibdin the padlock signifies at once Mungo's continuing enslavement and Leonora's ongoing confinement, as well as her inability to escape potential subjection from either husband-to-be. Women's oppression in marriage parallels Oriental captivity and Caribbean slavery.

Mungo's performance in the opera buffa toggles uneasily between acceding to society's assumptions about black inferiority and honouring his essential humanity. Engravings of Dibdin's Mungo show him blacked up, and his striped costume alludes to his Caribbean origins (see Figures 2.3 and 2.4).

James Gillray's caricatures and Agostino Brunias's paintings of West Indian scenes similarly represent African slaves and Creole women wearing colourfully striped linen turbans, dresses, and trousers. ${ }^{27}$ While the history of striped clothing reveals a medieval association of stripes with the Devil, striped fabric later became a sign of slavery or imprisonment. Around the time of the American Revolution, stripes began to take on rebellious connotations, and wearing stripes could indicate sympathy for the colonists' cause. ${ }^{28}$ Thus, Mungo's clothing may, like the comic

\footnotetext{
26 The lovers' parts were sung by Joseph Vernon and Elizabeth Arne, who was replaced by Eleanor Radley after her unexpected death on 1 May 1769. Charles Bannister played Don Diego.

27 On caricature and 'black humour', see K. Dian Kriz, Slavery, Sugar, and Refinement: Picturing the British West Indies, 1700-1840 (New Haven: Yale University Press, 2008), 71-116.

28 Striped costuming, a visual geographic or racial marker, reinforces Mungo's slave status and alignment with the Caribbean. Michel Pastoureau, The Devil's Cloth: A History of Stripes and Striped Fabric, trans. Jody Gladding (New York: Columbia University Press, 1991), 110 n.51, posits that American revolutionaries chose 'striped cloth, symbol of slavery (already in 1770, the prisoners in Pennsylvania and Maryland penitentiaries wore striped clothes), to express the idea of the serf who breaks his chains, and ... to reverse the code of the stripe: stripes, a sign of the loss of freedom, become, with the American Revolution, a sign of freedom gained'.
} 


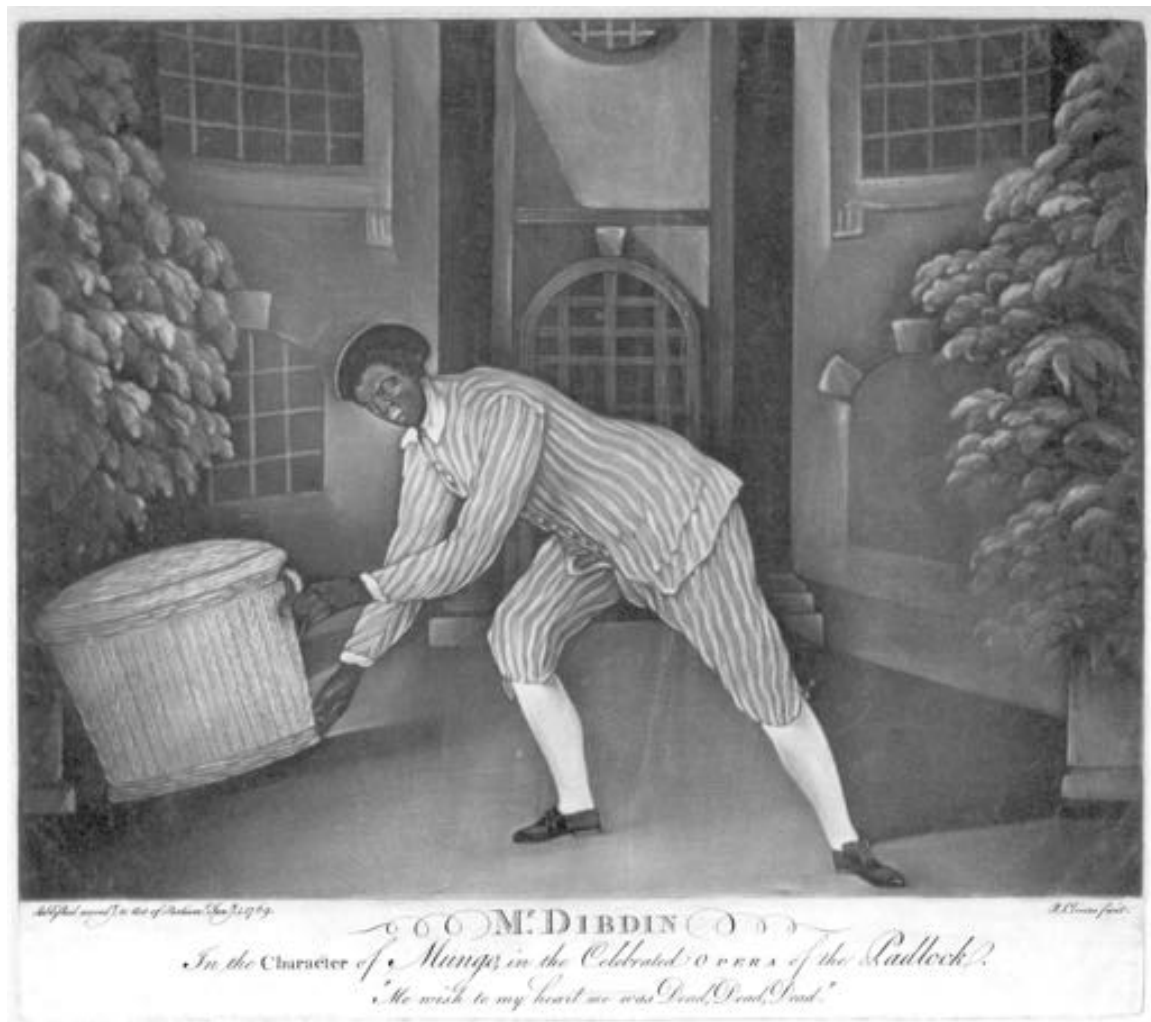

Figure 2.3. Butler Clowes, Mr. Dibdin as the Character of Mungo, in the Celebrated Opera of the PADLOCK (1768). London, 1769. Mezzotint. Courtesy of the Harvard Theatre Collection.

opera and its epilogue, have visibly signified in the British context at once both freedom and resistance, slavery and emancipation, to reflect the many contradictions represented by his character. ${ }^{29}$

A spoken epilogue to The Padlock appeared in The Gentleman's Magazine, purportedly written nearer to 1768 , but published only in October 1787,30 to freight the comedy with abolitionist sentiments. Mungo contests the audience's laughter by appealing to their compassion and calls 'for stronger, deeper feelings here'. He seriously demands his right to justice, to property, and to marry and have children, in a serious plea to Britons that he be accorded full humanity: 'Comes freedom then from colour? Blush with shame, / And let strong Nature's crimson mark your blame.' That this epilogue appeared in The Gentleman's Magazine, a

29 In contrast, Prithi Kanakamedala in 'Staging Atlantic Slavery', in Swindells and Taylor, Handbook of the Georgian Theatre, 673, argues that stripes erase Mungo's 'African origins'. That they may signify a 'handicap or liability' seems more plausible.

30 'Epilogue to The Padlock', The Gentleman's Magazine 57, part 2 (October 1787): 913-14. 


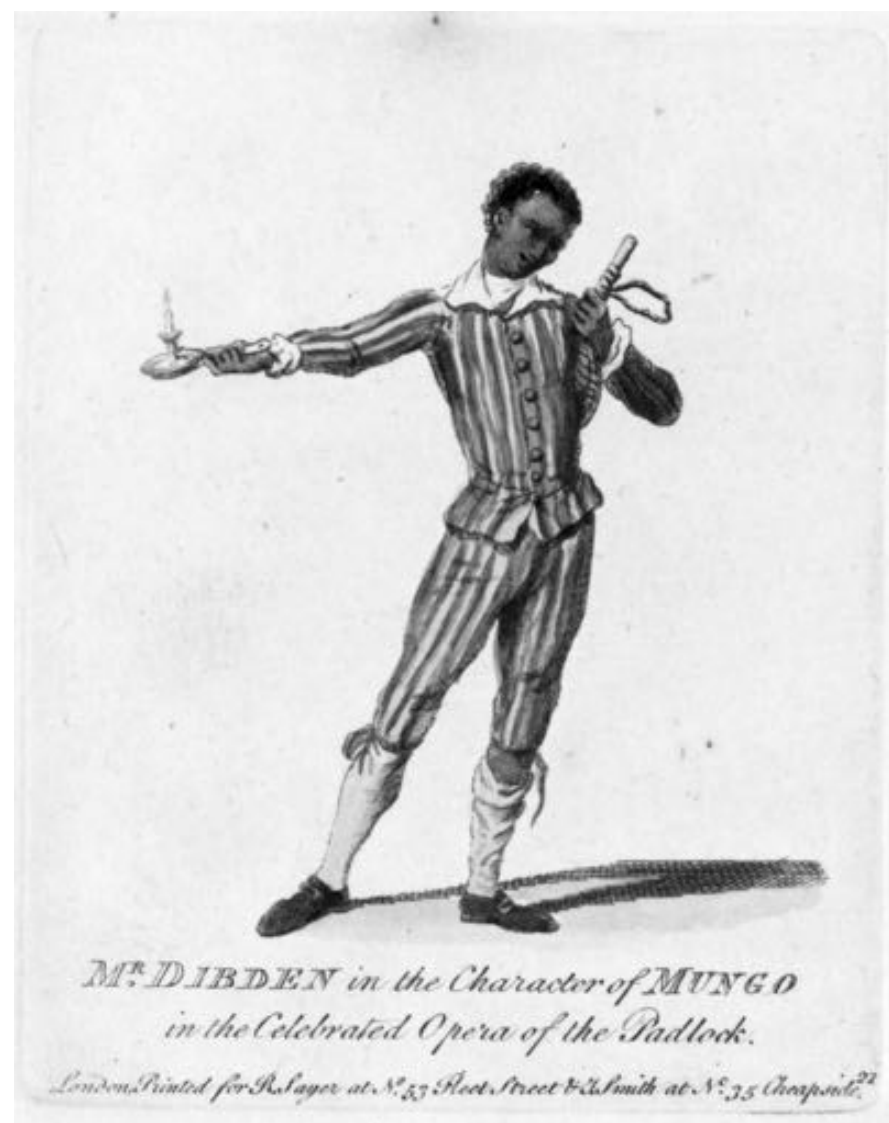

Figure 2.4. Mr. Dibden in the Character of Mungo. Engraving. From Dramatic Characters, or Different Portraits of the English Stage (London, 1779).

widely distributed periodical, suggests that The Padlock evolved in the nineteen years following its first production to turn away from the satirical treatment of a drunken servant outsider towards a plea for slave freedom as the alien appeals for his rights: 'For though no Briton, Mungo is a man!' (914).

While Mungo's blackface presence in The Padlock has been frequently discussed in recent years, the music to the comic opera has received scant attention. The score is vital to the characterization of the painfully abject Mungo and adds to the audience's sympathetic response, but it also highlights the comic incongruity of pairing West Indian dialect with traditional English and Italian tunes. Dibdin's strengths as a composer and librettist lay in creating memorable melodic and vocal lines that parallel the play's dramatic action and encourage expressive movement and gesture. The comic opera was especially notable for its use of 'flusters and blusters', and quick 6/8 time. Some listeners found the rapid repetition of the twoor four-bar phrases annoying but credited it with making the music easy to 
memorize and imitate. Audiences apparently sang the songs in synchrony with the performers as they had for John Gay's popular Beggar's Opera (1728), and they carried the melodies into the street. ${ }^{31}$

The Padlock is characterized by often nonsensical, yet appealing, sentimental arias, and a choral finale provides thematic resolution. Don Diego's bass pitterpatter, for example, makes him even more ridiculous in song than in speech. Following the opening overture with its allegro, andantino, and presto, he enters musing, along with his elderly housekeeper Ursula. Here is the printed text:

... A cuckold, must that follow?

Say what men will,

Wedlock's a pill,

Bitter to swallow,

And hard of digestion.

But fear makes the danger seem double.

Say, Hymen, what mischief can trouble

My peace, should I venture to try you?

My doors shall be lock'd,

My windows be block'd;

No male in my house,

Not so much as a mouse:

Then, horns, horns, I defy you.

Don Diego's repetitions, sung Andante con motto, comically emphasize 'cuckold', 'Hymen', 'hard', and his potential horns. Set to lively melodies that easily commit themselves to memory, the libretto switches to an allegro chant:

A Cuckold, a Cuckold, a Cuckold, a Cuckold, a Cuckold must that follow. Say what Men will, Wedlock's a Pill, bitter to swallow and hard hard of Digestion. Say what Men will, Wedlock's a Pill, bitter to swallow and hard hard of digestion. ${ }^{32}$

The concluding presto section sung in a silly rhyming patter reveals Don Diego's anxiety and pairs Hymen, the Greek god of marriage, with the horned sign of cuckoldry (see Figure 2.5). The word 'horn' is punned with the sound of the cornets:

But Fear makes the danger seem double, But Fear makes the danger seem double, Say Hymen what Mischief can trouble, say Hymen what Mischief can trouble, say Hymen, say Hymen what Mischief can trouble my Peace should I venture to try you, my Doors shall be lock'd, my Windows be block'd, my Doors shall be lock'd, my Windows be block'd, my Doors shall be lock'd, and my Windows be block'd, No Male in my House not so much as a Mouse, my Doors shall be lock'd, and my Windows be lock'd, no Male in my House not so much as a Mouse, then Horns Horns Horns! [as the cornets twice repeat the notes] then Horns Horns Horns! The Horns Horns I defy you, my Doors shall be lock'd and my Windows be block'd, then Horns Horns I defy you, no

31 Fiske, English Theatre Music, 348-53.

32 The Padlock. A Comic Opera: As it is Performed at the Theatre-Royal in Drury-Lane... The Music by $\mathrm{Mr}$ Dibdin (London, n.d.), 6-7. Subsequent quotations are cited in the text by page number. 


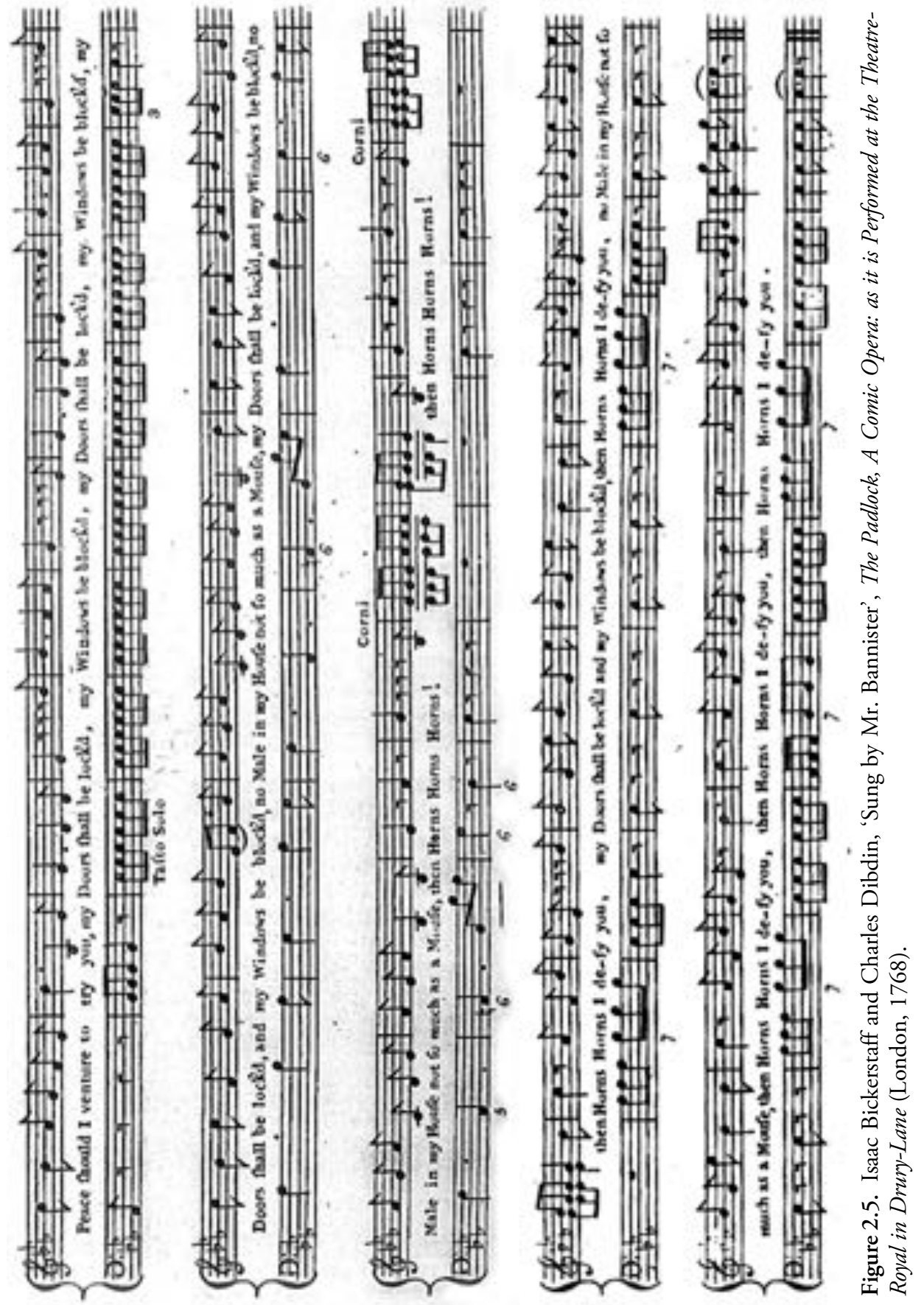


Male in my House not so much as a Mouse, then Horns Horns I defy you, then Horns Horns I defy you, then Horns Horns I defy you. (7-8)

Every repetition, then, allows Don Diego to engage in the ribald word play that reinforces the theme of fearing an adulterous wife and makes the tyrant seem much sillier than the words alone.

Similar arguments about the way that the music reinforces meaning could be made about every song in the comic opera. Leonora, for example, imitates bird sounds when she sings an aria to her pet robin accompanied by a piccolo. Enjoining the robin not to fly away, she trills over the word 'happy': 'Were you wanton could you be half so happy as with me?' (11). The lines in which Leonora compares herself to a caged bird are repeatedly reiterated as she imagines flying ('away I'd fly', 15) over a sheep meadow singing an aria with runs above high $\mathrm{C}$.

The aged Diego, contesting his reputation as an impotent old man, ascends the scale while singing 'I feel my Blood mounting like Streams in a fountain.' He insists on his 'Ability still', but the high tenor Leander indicates his superior reach—and virility - by hitting a high $\mathrm{C}$. His virtuosity matches his beloved Leonora's in their melodic duet that ends the scene.

In contrast, baritone Mungo complains of his misery in the aria mentioned earlier, 'Dear Heart, Dear Heart, what a terrible Life am I led'. He repeats emphatically the words 'dog' and 'dead', and he continues grumbling about the tedious hardships that define his life: 'Night and Day 'tis the same, my Pain is their game'. Best known, of course, is 'Mungo here, Mungo there, Mungo ev'rywhere' and the concluding lines, 'I wish to my Heart I was dead! dead! dead! I wish to my Heart I was dead! dead! dead! I wish to my Heart I was dead' (20). Further, when Leander teaches Mungo to play the guitar, the score imitates the sounds of various instruments. Mungo and Ursula sing antiphonally rather than in unison like the young lovers, but all four join together for an ironic chorus about harmless pleasure as Leander scales Diego's wall in spite of his 'lame' leg.

The neighbouring convent's bells signal that Leonora and Leander will live harmoniously, as their sweet-sounding duet echoes the tolling. In contrast, Don Diego's histrionic response upon returning to his violated domestic space is a fastpaced patter that simulates his heartbeat: 'Thumping and jumping and jumping and thumping and thumping and humping and humping and thumping and thumping and jumping and thumping, goes thumping \& jumping and thumping goes thumping $\&$ jumping and thumping' $(32,34)$. The phrase is, of course, printed only once in the play script, but in the musical rendering it is endlessly repeated. In the concluding ensemble, each character speaks about fetters, and everyone, including Mungo, sings a refrain that reinforces the moral and applies equally to disobedient wives and rebellious slaves: 'Let all her ways be unconfin'd, and clap your padlock on her mind.' 33 In short, the comic irony and musical fun

33 The Prior poem concludes, 'Be to her Virtues very kind: / Be to her Faults a little blind: / Let all her Ways be unconfin'd: / And clap your Padlock—on her Mind.' 
can only be fully appreciated when the script is interpreted in tandem with the accompaniment.

\section{DIBDIN'S OTHER ENTERTAINMENTS ABOUT BLACKS AND SLAVERY}

A much less successful comic entertainment than The Padlock, Henry Bate's twoact opera buffa The Blackamoor Wash'd White (February 1776), also scored by Dibdin, closed after four nights at Drury Lane, but the song lyrics were published separately as Airs, Ballads, \& c c. in the Blackamoor Wash'd White (London, 1776). ${ }^{34}$ In the unlikely plot Sir Oliver Oddfish, fretting that his wife and daughter will engage in affairs with his white servants, vows to hire only black servants, 'a regiment of Blackamoor Devils' (1.1). At the debut of the afterpiece the audience responded with 'Much hissing and Crying out no more no more!' Subsequent nights were equally rowdy as manager David Garrick unsuccessfully attempted to quiet the unruly spectators and eventually withdrew the play. ${ }^{35}$ The audience's discontent may well have been sparked by the comic opera's coarse language and racially charged material. The English and Italian melodies chafe against faux West Indian dialect as they had in Mungo's songs. The lyrics elide exotic difference as the alien intermingles with European tunes.

In both The Padlock and The Blackamoor the blackface character presents a splintered identity that reflects a dissonance between what is spoken or sung and the body that intones it. Oddfish is the target of the opera's joke because one of the newly hired servants proves to be an English soldier Frederic, the suitor of Oddfish's daughter Julia. Disguised as Amoroso, Frederic's West Indian dialect is peppered with the sexual double entendres typical of fabliaux. Oddfish's nephew Greville encourages Frederic in his defiant scheme, likening blacking up to violating linguistic and social conventions, 'nay their very principles'. The racial slurs and denigration of blacks_-'blackey man', 'Neger', 'raven', 'magpye', 'ugly devil', and 'saucer eyes'issue principally from the white valet Jerry whose position is most threatened.

Just as Leander had done, Frederic extends the connections of slavery to an Orientalized North Africa when he sings about an Egyptian who discovers that a 'young Teaf' (meaning 'thief', 2.1) plucked the fruit of his precious cherry tree while he was napping. The parallel to Oddfish's bizarre attempt to guard his women's virtue is obvious. In the carnivalesque atmosphere of the comic opera,

${ }^{3}$ H. Bate Dudley (Henry Bate), The Black-a-Moor Wash'd White: A Comic Opera (1776), Larpent MS 400, Huntington Library; subsequent references are to this unpaginated text; and The Overture \& Favorite Songs in the Blackamoor: A New Comic Opera (London, n.d.) in St. Andrews University Library. See Felicity Nussbaum, The Limits of the Human: Fictions of Anomaly, Race, and Gender in the Long Eighteenth Century (Cambridge: Cambridge University Press, 2003), 220-6.

35 George W. Stone Jr (ed.), The London Stage, 1660-1800, Part 4, 1747-1776, (Carbondale: Southern Illinois University Press, 1962), 1948-50. The Westminster Magazine review (February 1776), 4: 82-3, finds the dialogue 'not only barren of wit, but coarse to an extreme'. Calling 'the Music of several [songs] very pleasing', the reviewer objects to the ridiculousness of the plot, though not to Frederic's blackface. 
Jerry, referring to the glutting of the British labour market with the cheap labour of freed slaves, laments, 'Why surely the times are turn'd topsey turvey, that white Englishman $[s i c]$ should give place to foreign Blacks!' Another favourite ballad was one that Greville/Mr King sang about the moral certainty of British soldiers: 'Brittish [sic] boys will still be right / 'Till they prove that black is white!' (1.1).

East and West Indian, like the ancient Egyptian in The Padlock, are interchangeable in their blackness:

\section{M'hap the Nabob that brought the poor Creature \\ From Father, and Mother and all Is himself of a Blackamoor nature \\ Dark within as the tribe of Bengall.

In other words, the white nabob who wrenched the black slave from his parents is himself, ironically, a blackamoor at heart. Having recognized Frederic by his singing voice, Julia embraces the lute-playing blackamoor, though of course he proves reassuringly to be white, thus averting an Othello-like tragedy. Perhaps the fact that Dibdin only composed the score but did not play the blackface role may have contributed to The Blackamoor's failure.

I have been focusing mainly on the Dibdin of the 1760s and 1770s, but in the late 1780s and 1790s Dibdin made commercial use of his renown as a blackface character when he parlayed his talent for mimicking West Indian accents into staged recitations and singing performances called 'Readings and Music' and 'Table Entertainments'. Dibdin accompanied himself on an inventive one-manband piano-organ with an attached set of bells, a drum, tambourine, gong, guitar, and lute. Incorporating these into one instrument, Dibdin anticipates the bones, banjo, and tambourine that would later accompany minstrelsy.

At this later point in his career, Dibdin attempted to present himself as respectable and patriotic, and just how his slave songs fitted into the growing sentiment for abolition can only be conjectured. Included in Dibdin's evening's entertainments were a number of 'Negro Songs' in dialect such as 'Kickaraboo' ('kick the bucket'), in which a slave sings, dances, and plays a banjo to postpone death. The memorable opening couplet, variously rendered, predicts a paradisial future of seeming racial harmony: 'Poor negro say one ting you no take offence / Black and white be one colour a hundred year hence.' ${ }^{36}$ One early commentator, noting Dibdin's special skill in representing 'negro characters', provides a telling transcription of his anecdote, 'A Sketch of Crude Vice and Virtue', about a trickster slave Cudjo and his mulatto friend Quaco. The two drink the rum they are supposed to carry to Cudjo's master and substitute river water: 'Come to the ribber, put lilly wee drop water.' 37 The letter Cudjo is charged to deliver metamorphoses into a talking tattletale that exposes their ruse, even though they hide the note under a stone. ${ }^{38}$

36 Cruikshank, Universal Songster, 1:29.

37 Leman Rede, The Road to the Stage, xix.

38 Musical Tour, 358-60. In another version Cudjo further mocks the mulatto ('dam yellow copper kin-you no nation-you a mule') for not knowing his father's identity and lampoons his sister. 
Dibdin treats the gullible black men as ignorant, but he justifies telling the story because it allegedly offers a fable-like moral that reveals the consequences of envy: 'Had Juvenal been a Negro he would have written in the language of Cudgo [sic].'39

Dibdin incorporated other uncouth 'Negro songs' in dialect into his solo entertainments including 'One Negro come from Jenny Land', 'One Mountain Neger he no find', and 'The Sun Go Down, the World Take a Breath'. These songs express sympathy for the relentless labour and cruel beatings slaves endured, but they also gloss over the 'massa's' injustice and thus seem more ameliorist than antislavery. For example, in the 'Negro duet' of 'The Sun Go Down', the exhausted, sun-blistered workers dance, sing, and play the banjo to 'drive away to-morrow'. Sounding the ching ring or tambourine, they dream of escaping the overseer's whip in the afterlife:

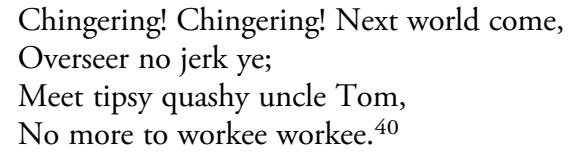

In 'One Mountain Neger' when the grateful slave finds a kind master, he swears to serve until death; ${ }^{41}$ again in 'One Negro come from Jenny Land', Cudgo, unable to find peace in this world, is made a cuckold when his master impregnates his wife Quashy, producing a 'squalling pick-a-ninny'. The song counsels acquiescence when confronted with unconscionable actions and postpones hope until the afterlife: 'Wear horns and be contented'. Dibdin's striking and shaking the tambourine in accompaniment mimics the percussive cracking of the whip in the refrain: 'Ching, Ching'ring, ching; Ching, Ching'ring, ching so hard / Poor Negro worky, worky.' ${ }^{2} 2$ Published in America as well as England, these songs condemn the brutality of slavery, but they cannot be construed as songs promoting abolition.

\section{DIBDIN'S ORIENTAL ENTERTAINMENTS}

Dibdin blends slavery's miseries with Eastern captivity and exoticism in a number of his other musical entertainments, probably having been influenced by the popularity of The Arabian Nights (1707-17). ${ }^{43}$ His Magic of Orosmanes; Or, Harlequin Slave and Sultan: A Pantomime, Drawn from the Arabian Legends (1785), smooths over the differences among captives of all kinds in various geographical locations. It follows the pattern of harlequinades in which a black

39 Cited in Hans Nathan, 'Negro Impersonation in Eighteenth Century England', Notes, 2nd series, 2/4 (1945): 245-54, 251, from Musical Tour.

40 'The Sun Go Down, the World Take a Breath' in Hogarth, 1:81-2.

41 Hogarth, 1:81-2.

42 Cruikshank, The Universal Songster, 1:403. 'Jenny' is a town on the northern coast of Suriname.

43 By 1800 eighty English editions of Antoine Galland's Les Mille et une nuits, popularly known as The Arabian Nights, had been published. 
slave turns into a harlequin who is ultimately given his liberty. The Magic of Orosmanes, opening with an active slave market, introduces enchained men and women who sing of their longing to be free:

Tho' in indignant chains confin'd,
And lost to liberty,
Yet, spite of these, the noble mind
In slavery dares be free.

The chief eunuch singles out the Harlequin and the Clown as mutes to purchase for the seraglio, the Eastern equivalent to chattel slavery. Enlisted as slaves, they are unable to speak their resistance. Harlequin, sounding the theme of a dance of death, comically contemplates various methods of suicide as preferable to slaverypoison, a pistol, or a noose.

Dibdin's spectacular entertainment, accompanied by foot-tapping tunes that deflect the horrors of captivity, lightens the burden of enslavement and transforms it into an effect of enchantment. Phillip James de Loutherbourg's magnificent scenery created in seriatim the illusion of a seraglio, the seacoast, a rural grove, a desert, a palace, Covent Garden, and the Haymarket. Orosmanes reveals that the Sultan Osmyn magically 'shrunk' Harlequin into an ape to prevent his marriage to the Sultan's daughter, Zulma (1.2). The roving party meets up with a motley group at an inn, including two Janissaries, who, in an echo of Dibdin's racist anecdote, are duped into believing that the water they are drinking is wine.

Though the comic operas are darker than the harlequinade, both genres raise historically contingent issues around slavery, captivity, and the rights of women. Dibdin's music for the pantomime has not been found, but The Magic of Orosmanes interestingly resembles The Padlock in its double response to slavery as comic, yet allowing for defiance. After a series of misadventures, Harlequin subdues his enemies and is happily released into his natural form. Slavery, then, is reduced to a magically induced, transformable state rather than a deliberate, irrevocable, commercial transaction.

Enslavement in its various manifestations, then, connects Dibdin's dramatic entertainments, whether the captive is West Indian, African, Moor, or Turk, male or female. Letters in The Musical Tour of Mr Dibdin (1788) reflect the composer's conflicted attitude towards slavery as a staged epistolary debate between advocates from Manchester (pro-abolition) and Liverpool (pro-slavery). Dibdin's abolitionist letter accuses his countrymen of inciting 'the natives to commit partial depredations on each other' and urges merchants to give up the trade, 'a disgrace to humanity'. ${ }^{44}$ The Liverpudlians, on the contrary, claim that slavery is a blessing that the Africans prefer to being sacrificed, eaten, or sold in their native lands. The happy slaves are treated with 'mildness and lenity' in the Middle Passage; ${ }^{45}$ they are mercifully subject to no more than thirty-nine lashes, and are granted a bit of ground to work. Dibdin's final ameliorizing sentiment is probably most reflective of his views: simply correcting slavery's abuses rather than abolishing the trade would

${ }^{44}$ Musical Tour, $221 . \quad 45$ Ibid., 227. 
have made the reasonableness of this position self-evident because, he contends improbably, at least one slave ship offered the slaves more 'comfort and convenience' than the crewmen. In the end Dibdin equivocates, thus reflecting the tensions apparent in his entertainments: 'It would have exceeded my duty to say whose arguments are the most worthy [of] attention.' ${ }^{46}$

The site of slavery's amusing miseries moves to the seraglio in two of Bickerstaff's other short pieces that were accompanied by Dibdin's music, The Captive (1769) and The Sultan; or, a Peep into the Seraglio (1775), along with Dibdin's two-act Seraglio (1776). In the singing farce The Captive, Dibdin is responsible for six musical numbers $(1,4,6,10-12)$, five of which were drawn from Italian operas. ${ }^{47}$ Male and female slaves, some described as black, sing about their pleasure in working the gardens:

Ah, how sweet the rural scene!

Circled by those charming groves,

Slavery its labour loves,

And the captive hugs his chain.

The play echoes the frame tale of The Arabian Nights, as well as other harlequinades and comic operas in which a sultan suspects his wife of adultery. Posing as a slave reduces captivity to a mere performance as the Cadi sings of his vigilant attentiveness to her actions:

In emblem I am like a cat

That's watching for a mouse...

Just so will I watch her,

And so if I catch her,

I'll worry her out of her life.

Eastern women are the agents of Christianity, patriotism, and liberty in many eighteenth-century plays, for the love of a good Christian woman frequently reforms an Eastern despot. In Dibdin's two-act Seraglio, the harem and its slaves are set in the context of ship and seashore. ${ }^{48}$ The Turkish bashaw (curiously played by a cross-dressed actress) is a slave to Abdallah, who rules a seraglio but transforms from despotic stereotype to an enlightened ruler who belatedly fulfils his promise to allow Elmira, 'a slave among strangers', to become empress. Finally she convinces him to free the English captives: 'Load these Christians with Riches, and give them safe and honourable Conduct to their own Country' (2.2).

Bickerstaff's The Sultan; or, a Peep into the Seraglio (1775), including two songs by Dibdin, again features a captive woman's persuasion of a Turkish sultan to

46 Ibid., 232.

47 The score to The Songs in the Comic Opera of the Captive (London, 1769) is held in the British Library collection.

48 Charles Dibdin, The Seraglio; A Comic Opera, in Two Acts (London, 1776). The lyrics to Dibdin's popular sea song, the rondeau 'Blow high, blow low' appear in Airs, chorusses, \& c c. in the New Musical Entertainment of The Seraglio; as it is performed at the Theatre-Royal in Covent Garden (London, 1776), as well as The Overture, Songs, \& c., in 'The Seraglio'(London, 1776). 
disband his harem and emulate 'civilized' Christian culture. The Sultan favours the spirited English slave Roxalana (famously played by Frances Abington), but the eunuch Osmyn finds Elmira, a Georgian slave, and Ismena, a Persian captive, more amenable: 'Court the charms of the fair, of the black, of the brown. / They're flowers that embellish the garden of love.' ${ }^{49}$ Just as Mungo protested against his confinement in The Padlock, the insolent Roxalana vehemently objects to her captivity, and she proves triumphant in instituting change. In the unlikely original ending, Roxalana becomes the Sultana but willingly gives up her power because the Sultan promises to treat her as an equal.

Most relevantly to our discussion of Dibdin's views on slavery, the eunuch Osmyn was originally intended to be a blackface role, perhaps as a means to build on the popularity of Mungo. The Larpent manuscript (though not the printed version) lists him as 'Osmyn Kislar-aga, Or Chief of the Black Eunuchs', and the black mute eunuchs enact stage business. ${ }^{50}$ Roxalana calls Osmyn a 'blackamoor' in the manuscript version of his soliloquy, but the epithet was omitted in performance, perhaps because Dibdin, no longer associated with Drury Lane, would not have been available to play the blackface role. After the first night, erotic allusions to the sexual services required of the seraglio slaves were also struck out. According to The London Stage, the five songs were reduced to two-one by Ismena, the other by Osmyn-in subsequent productions. ${ }^{51}$

Eighteenth-century entertainments, according to music historian Berta Joncus, 'purged the Orient of otherness' merely to gesture towards an 'exotic patina' of the East that was 'reduced to an ornament, designed to enhance its wearer'. ${ }^{52}$ Certainly this is true of the music, for neither libretto nor musical score imitates Eastern sounds (although Janissary musicians with drums, bells, and cymbals occasionally appeared in other productions); they rely instead on English and Italian melodies and instruments. For Dibdin it was easier to incorporate linguistic, musical, and corporeal differences from the West Indies than from the East. Yet whether viewed from the East or West, being enslaved or held captive lent itself musically, at least, to comedy, unlike the tragic African counterparts of Othello or Oroonoko, or the tragic Eastern heroines such as Cleopatra, Zara, Zobeide, or Semiramis.

In short, Dibdin's compositions, moving nonchalantly from songs about African slaves to Eastern captives and seraglios, reveal the contradictions of racial thinking and emancipatory discourse in the early days when abolitionist and pro-slavery views sometimes shared common elements. Riddled with contradictions, early articulations of racial thinking do not fit easily into the patterns they would assume

49 The Sultan; or, a Peep into the Seraglio; A Farce in Two Acts (London, 1781), 1.1.

50 Larpent MS 397, Huntington Library, unpaginated.

51 Stone, The London Stage, Part 4, vol. 3; Peter A. Tasch, 'Garrick's Revisions to Bickerstaff's The Sultan', Philological Quarterly 50/1 (1971): 141-9, 145 n.9; and Larpent MS 397, Huntington Library.

52 Berta Joncus, "Nectar if you taste and go, Poison if you stay": Struggling with the Orient in Eighteenth-Century British Musical Theatre', in Philip F. Kennedy and Marina Warner (eds), Scheherazade's Children: Global Encounters with the Arabian Nights (New York: New York University Press, 2013), 283, 309. 
after 1833. Because Mungo challenged his ill treatment, we might assume that Dibdin, having popularized comic blackface, was prescient in voicing abolitionist sentiments. While it is true that the trickster Mungo, like other slave characters, 'engaged in a power struggle with his master, a reminder to audiences that slave owners did not really know their slaves', 53 the black servant was mocked for his drunkenness and obsequiousness as much as he was pitied because of Diego's abuse. As we have seen, later in the century Dibdin continued to promote himself for commercial gain as an entertainer exploiting racialist anecdotes and coarse sentiments. Dibdin caricatured African slaves, Eastern monarchs, eunuchs, and upstart women to further his career rather than to forward human rights. Dibdin's light-hearted music stirred sentimental feelings for overworked and mistreated slaves, but its comedy reassured a nation intrigued by alien peoples and practices that English boys would still prove white; that feisty Englishwomen would convert sultans and help free Europeans held captive in foreign lands; and that grateful black slaves, rather than rebelling against injustice, should content themselves with hopes of an afterlife. The comic opera of the mid- and late eighteenth century becomes a catalyst for racially inflected farcical dialogues, nonsense songs, catchy refrains, mock dialect, pitter-patter, and musical repetition. Dibdin's happy entertainments, then, played a critical role in intimating that the threat of slave rebellion could be kept at bay, that tyrannical sultans might be tamed, and that a simulated encounter with the exotic would ensure the preservation of British virtue and values. At the same time, however, they also recognized at some level that entertainments like these allowed them to deflect the serious issues of the day by singing merrily and laughing heartily about captivity and slavery. 


\title{
3
}

\section{Dibdin at the Royal Circus}

\author{
Michael Burden
}

Dibdin-inspired, mercurial, and financially slapdash-was perhaps not the best person to be involved with the intricacies of running a theatre, let alone one in which he would be one of a triumvirate. But in 1782, that is just what he did when he began his association with what would become the Royal Circus Equestrian and Philharmonic Academy. ${ }^{1}$ This venture presented a range of miscellaneous entertainments, including feats of horsemanship, allegorical scenes, music, and songs, much of it in performances by children being trained for the stage. The enterprise had its origins in the activities of Charles Hughes (1746/7-97), a 'strong man' and former employee of the pioneer equestrian showman, Philip Astley (1742-1814), who had opened his ring in what is now the Waterloo area of London in 1770. Hughes left Astley's employ and opened his own exhibition and riding school ring in opposition in 1771; it was closed by the magistrates in 1773, and Hughes then embarked on an eight-year tour of Europe and Russia. When he returned to London, Hughes teamed up with Dibdin, who was feeling hounded out of the different London theatres, and they began this new project-the Royal Circusthat involved the staging of mixed entertainments.

Both Hughes and Dibdin brought to the new venture substantial experience of competing in the London theatrical marketplace. This chapter explores how they used these experiences to develop an innovative form of public entertainment that would be able to compete in the burgeoning and cutthroat world of the London minor theatres. Through a combination of architecture, spectacle, music, and novelty, they sought to outdo their rivals and achieve commercial success. Their case offers an insight into the increasingly fierce competition that lay behind the striking innovations of the minor theatres in this formative period of their development. ${ }^{2}$

\section{LOCATION AND ARCHITECTURE}

Crucial to the success of any new theatre in late-eighteenth-century London was the need to acquire an advantageous site and a suitably impressive building.

\footnotetext{
1 This title appeared in some of the early advertisements: Morning Herald and Daily Advertiser (28 October 1782).

2 See Moody, Illegitimate Theatre.
} 
The building constructed for the Royal Circus was built south of the river, to the Surrey side of the new Blackfriars Bridge. The bridge's construction, completed in 1769 and promoted by the City of London Corporation, was part of improvements on both sides of the river, and its access road created a junction with the Borough, Blackfriars, and Westminster Bridge roads called St George's Circus:

The approach to the Obelisk, where the roads from the three Bridges of London concentrate, is not without its picturesque beauty; ... the spacious road which leads to Blackfriars Bridge is most worthy of attention. The houses on each side are superior in magnitude to the generality of structures in this quarter, and the equestrian theatre, called the Royal Circus, which rises in the fore-ground, by its variety of outline relieves the tame insipidity of the modern brick buildings, though it cannot be praised for the chastity of its architecture. ${ }^{3}$

The fact that it was accessible from all the bridges clearly made the site an advantageous one. It was not always safe; the area beyond the buildings consisted of much open ground, and there was potential for footpads and other dangers, which the theatre tried to ameliorate: 'In addition to the present Watch, a Horse Patrole $[s i c]$ is provided from the Academy door to all the bridges. ${ }^{4}$ Apart from its ease of access, another advantage was that the rule of the Lord Chamberlain did not extend to the Surrey side of the river, removing the need for licensing of both the premises and the works, although, as we shall see, the Royal Circus did not escape regulatory problems.

The site of the theatre was controlled by Colonel West, and with his funds and those of other supporters, a building was erected — supposedly at a cost of $£ 15,000$ with those funders becoming proprietors; according to George Hogarth, Dibdin was appointed sole manager for life, and was to receive a quarter of the profits. ${ }^{5}$ No architect can be identified for the Circus, seen in Figure 3.1, but the evidence suggests an attempt to project an air of classical grandeur. It was claimed that it resembled 'the circuses of antiquity', in particular the Circus Maximus in Rome, whose entertainments had included 'horse-coursing'. Such puffery was to be expected, but we do learn that 'at the top of Hughes's Circus is a figure of Pegasus, as applicable to a part of the amusements of the place'. ${ }^{6}$ And sure enough, the 1795 painting includes the Pegasus on a plinth at the apex of the gable on the main facade. This was a gesture designed to reinforce the classical aspirations of the architecture while simultaneously drawing attention to the equestrian nature of the entertainments. Providing for the comfort and refreshment of the clientele was another vital feature of a successful theatrical building: 'We hear an elegant coffee room is fitting up at the Royal Circus, which has a communication with the box lobby, for the purpose of serving the company with Ices, Orgeat, Lemonade, and other refreshments.'7 Whether the building was entirely completed when it opened is not clear,

3 Thomas Malton, A Picturesque Tour through the Cities of London and Westminster, Illustrated with the Most Interesting Views, Accurately Delineated and Executed, 2 vols (London, 1792), 1:2.

4 Morning Chronicle and London Advertiser (23 December 1782).

5 Hogarth, 1:xvii. ${ }^{6}$ Morning Herald and Daily Advertiser (2 November 1782).

7 Morning Chronicle and London Advertiser (9 November 1782). 


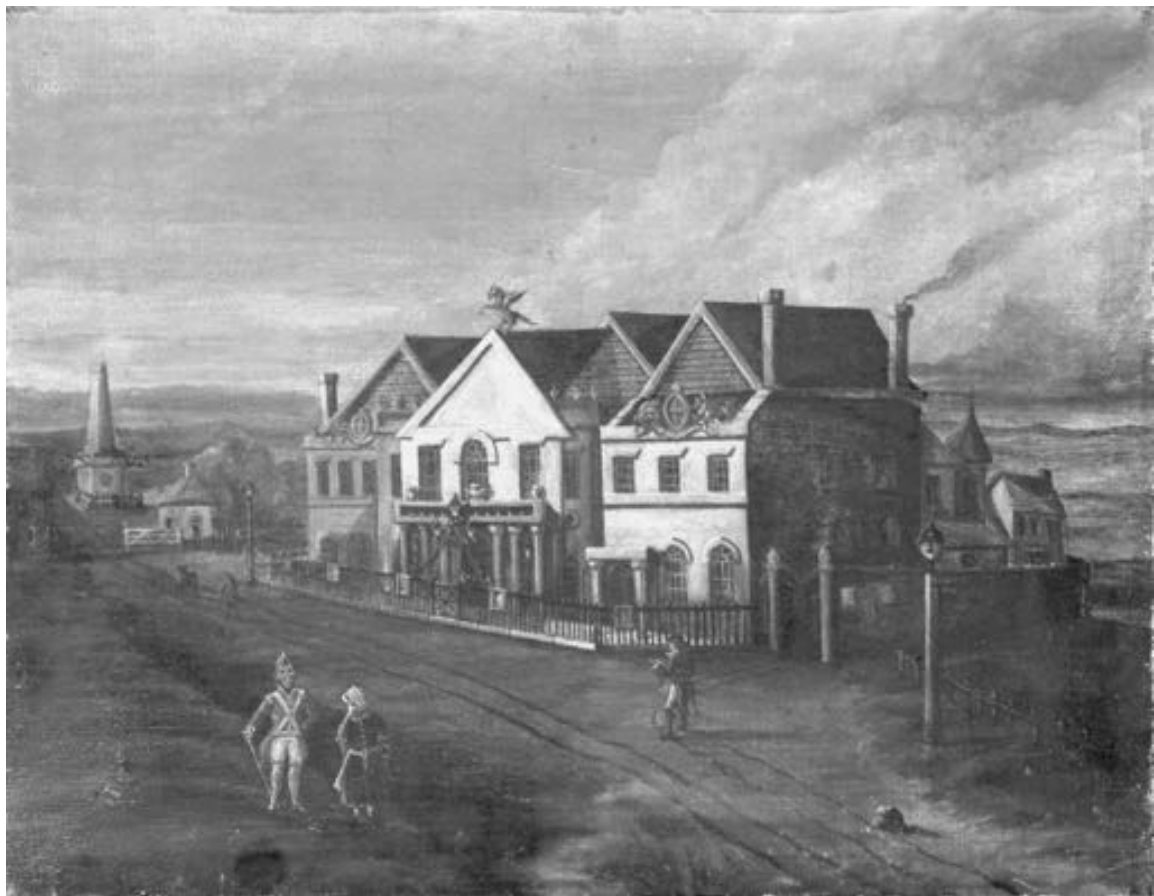

Figure 3.1. Anonymous, A view of the Royal Circus in St George's Fields. Oil on canvas, c. 1795. (C) Victoria and Albert Museum, London.

but a subsequent announcement suggests an unfinished (or just finished) building, a circumstance that may account for the curious fact that members of the public were not allowed in to see it before the opening night-it would have been good advance publicity to have allowed potential ticket holders to see a new theatre space. ${ }^{8}$ It was left to the London Chronicle to assist the circulation of rumours of the glories to be found therein: 'The stile in which it is arranged, with the light manner of its decoration (the colours being principally a straw-coloured ground with silver ballustrades $[s i c]$ and silver ornaments) gives the whole an air of simple grandeur, and forms a very striking and pleasant coup d'oeil.'

This new venture was unlikely to have been met with delight by actual or potential competitors, most especially those at Astley's Amphitheatre just a short distance away. And it was this competition that gave rise to a report that Hughes's horses were poisoned-three of them died-which contemporary newspapers believed not to have been a random attack, but aimed against the equestrian. ${ }^{10}$ So near to the action was he that Astley later felt constrained by rumour to deny having done it, ${ }^{11}$ for there was no doubt that Dibdin's venture was a serious

8 Morning Herald and Daily Advertiser (28 October 1782).

10 Public Advertiser (30 September 1782).

9 Quoted in Fahrner, 98.

11 Morning Herald and Daily Advertiser (14 November 1782). 
threat: 'Astley, with more understanding than the world gives him credit for, has wisely shut up his own theatre during the commencement of the more nouvelle and engaging exhibitions at the Royal Circus, thereby leaving his competitors to reap their well-earned harvest of public favour and applause.' ${ }^{12}$ This may have been a prudent move on Astley's part: by allowing the public to concentrate on the new enterprise, he avoided losing money on what would have been a split audience, and was able to re-open—as he did—once the novelty had worn off. Astley did not, however, have things all his own way; a circus puff suggested that, in response to the new enterprise, he had to lift his game: 'Upon the whole, we must declare, that it will be necessary for Mr. Astley to make some... improvements in his exhibition, unless he will allow his Amphitheatre to be totally eclipsed by the Royal Circus. ${ }^{13}$ The shows at the Royal Circus clearly had enough going for them to be seen as a credible threat to others in the business.

\section{RING, STAGE, AND SPECTACLE}

Fundamental to the competitiveness of the new building was Dibdin's innovative conception of a combination of a stage and an equestrian ring. In fact, the origin of the 'ring' for equestrian shows lay with Astley and developed out of his performance trademark of riding in a circle (as opposed to the straight line of his rivals), a format that allowed, on the one hand, the audience to see the riders throughout the performance, and on the other, the riders to generate a centrifugal force which assisted them in their horseback gymnastics. Astley developed his arena into 'Astley's Amphitheatre of Equestrian Arts', which opened in 1773. Astley, though, never called his institution a circus, leaving Dibdin to coin that usage. However, when Dibdin and Hughes joined forces, the latter's period in Astley's ring gave the Royal Circus the benefit of that experience.

In order to surpass the Amphitheatre and seize the competitive advantage for the Royal Circus, Dibdin decided that the stage should take a more prominent part in the performances. He claimed that his auditorium would allow for shows of scenes on the stage, accompanied by simultaneous equestrian events in the ring. His aim was 'to have a stage on which might be represented spectacles, each to terminate with a just [sic] or tilting-match, or some other grand object, so managed to form a novel, and striking coup-de-theatre ... [in a way] that the business of the stage and ring might be united'. ${ }^{14}$ Dibdin clearly hoped that the two theatrical spaces would speak to and complement each other. In realization, one commentator remarked that the auditorium was 'disposed in an oval form, at one end of which stands the stage, and round the other end are thrown the pit, boxes and gallery, the centre forming a kind of pit for equestrian performances'. ${ }^{15}$ Figure 3.2, originally

12 London Evening Post (9-12 November 1782).

13 Morning Post and Daily Advertiser (22 April 1784).

14 Life, 1:105. 15 Quoted in Fahrner, 98. 


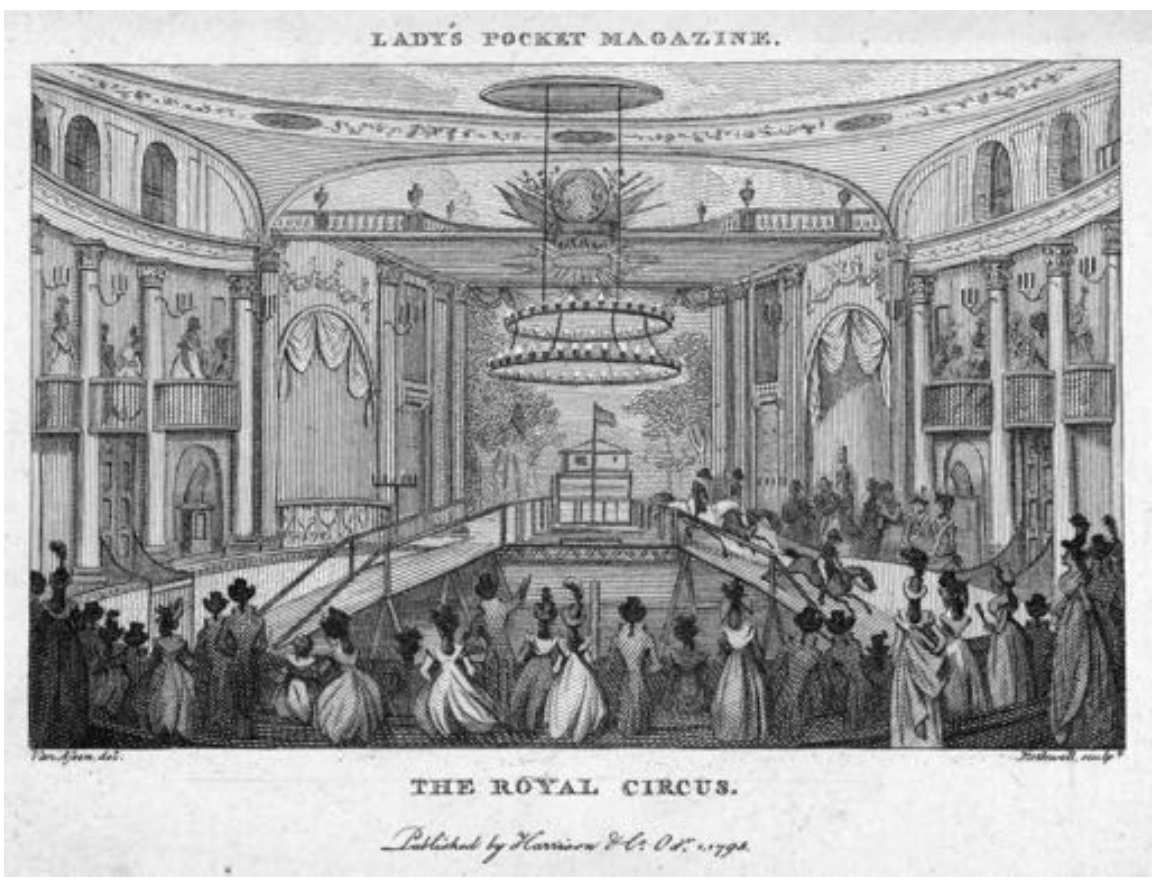

Figure 3.2. Thomas Rothwell, 'The interior of the Royal Circus'. London, 1795. From Lady's Pocket Magazine (London, 1795). Engraving. (O Enthoven Collection, Victoria and Albert Museum, London.

published in the Lady's Magazine, shows what appears to be a children's pony race in progress, with a miniature grandstand complete with pennant centre stage. It also suggests that there was a fairly large proscenium area containing what may be two stage doors with apertures above, and two large curtained stage boxes. Also pictured are two tiers of boxes, a gallery with 'pigeon holes', a pit, a large two-tiered candle chandelier, and (a decoration indispensable to any theatrical venue) a trophy over the centre of the proscenium arch; the stage itself had two slanted points of access to the arena.

\section{THE CIRCUS AS AN ACTORS’ NURSERY}

In showing children's pony races, Figure 3.2 points to one of the most interesting novelties the Royal Circus had to offer the London theatre public: performances by casts consisting entirely of children. These derived from the Circus's advertised function as an 'Academy' or actors' training school. London had previously had actors' nurseries; in 1663, the two patentees Thomas Killigrew and William Davenant petitioned the Attorney General for a grant to allow them to set up a 
third theatre 'for ye instructing of Boyes $\&$ Girles in ye Art of Acting'. ${ }^{16}$ A largely unsuccessful venture, it did, after a number of transformations, end up at the Barbican in 1671, and subsequently closed. More recently, in 1756, Theophilus Cibber had opened a 'histrionic academy for the instruction of young persons of genius' claiming that he wanted to teach them 'the Arts of Action and Elocution, \&c.... Thus this Academy may become a Nursery of Actors and Actresses'. ${ }^{17}$ Cibber opened it in a theatre at Richmond, Surrey, where it was advertised as a 'cephalic snuff warehouse' to avoid 'the penalties of the act of parliament against unlicensed comedians'. ${ }^{18}$ By the following season, Cibber's 'histrionic academy' was performing 'with great regularity and decorum' at Buckingham House in Southwark (also out of reach of the licenser) 'to a crowded and genteel audience', 19 but it seems to have been a short-lived enterprise.

There were therefore important precedents for nurseries, but these were, by the 1780s, defunct. Dibdin's announcement that the Royal Circus would offer such performances could thus be presented as an attractive novelty. Puffs in the London press announced that the performances would involve fifty children 'of both sexes, from six years old to fourteen', ${ }^{20}$ while Dibdin himself claimed to have engaged some sixty children to act as dancers and singers for his various productions at the Circus between 1782 and 1783. Nevertheless, other voices in the press, wise to the promotional tricks of theatre-managers, sounded a note of scepticism. The St. James's Chronicle remarked that 'this Place of Entertainment was opened under the Title of an Academy, but on what Pretense, we are yet to learn, as the Performances were mere Exhibitions, and not Schools for future Purposes'. ${ }^{21}$ Others interpreted it as a theatrical gimmick worthy only of the minor theatres: because the Royal Circus lay outside the jurisdiction of the Lord Chamberlain (unlike the patent theatres royal in London itself), the house was accused of leaping 'the low barriers of the Surrey Sessions' in using children to replace Astley's 'puppet shows'. ${ }^{22}$ Clearly, the demand for novelty that characterized the minor theatres was met with snooty disdain by certain sections of London society, but in the opinion of the Royal Circus management, the commercial imperatives driving such innovation evidently outweighed any potential loss of audience. And there was the law of unintended consequences; the scale of the personnel was such that it drew the critics' attention:

\footnotetext{
16 State Papers (Domestic) 44/15, 117-19, cited in Robert D. Freeburn, 'Charles II, the Theatre Patentees, and the Actor's Nursery', Theatre Notebook 48/3 (1994): 148-56, 150.

17 General Advertiser (8 July 1756), quoted in Daniel Lysons, The Environs of London: Being an Historical Account of the Towns, Villages, and Hamlets, within Twelve Miles of that Capital, 4 vols (London, 1795-6), 1:469.

18 Lysons, Environs of London, 1:469.

19 Public Advertiser (30 November 1757).

20 Quoted in Andrew McConnell Stott, The Pantomime Life of Joseph Grimaldi (Edinburgh: Canongate Books, 2010), 15.

21 St. James' Chronicle; or the British Evening Post (2-5 November 1782).

22 Ibid.
} 
Persons, Voices, Action, \&c. are in such astonishing Disproportion to the whole Circus, over which the Spectators view them, and even to the Stage on which they perform, that it impresses the Mind with Sentiments of Ridicule or Compassion. The Violence they offer to their little Organs of Speech, and the expanded and flying Mode of their Action, are the necessary Consequences of this radical Mistake. The Performers should be Giants, and not Pigmies. ${ }^{23}$

Not only were they too small in the context of the stage and proscenium, but the too-large space apparently did not accommodate the juveniles' immature voices and performing style. As always, the motives for such criticism are unclear, but the writer appears to have had a point.

The description of The Fairy World, a piece for which no libretto survives, suggests how some of the works thus 'staged' went. A show of horsemanship 'will be occasionally relieved by the Efforts of a Number of CHILDREN educated on the Academy, who will perform their Exercises in Music, Dancing, and Oratory, comprehending a Series of Whimsical, Temporary, Ad Libitum, Preludes, Intermezzos, Ballets, and Farragos, Grotesque and Demi-Character'. ${ }^{24}$ This miscellaneous collection of performances was designed to appeal to a broad clientele, but presumably also served a pragmatic function, with the children simply performing under the title of The Fairy World whatever items were ready from their lessons. The children clearly studied three things: speech, music (presumably singing), and dancing, which took up the lion's share of the performances, and which included a medley of grotesque and demi-character (a term suggesting 'telling a story through a dance') pieces. In the dramatis personae of a work such as the serenata The Cestus, we find that the majority of the successful children were offspring of other London performers. The Cestus is a masque-like piece, with a cast consisting of gods and goddesses: Jupiter was sung by Andrew Sestini; Mars by Rosine Simonet; Venus by Rosemond Wilkinson; Iris by Leonora Simonet; and Juno by Maria Romanzini. ${ }^{25}$ Andrew Sestini was probably the son of Giovanna and Vincenzio Sestini, both singers at the King's Theatre; Vincenzio was also the King's Theatre's tailor and costume designer. The Simonet sisters, Rosine and Leonora, were the daughters of the King's Theatre dancers, Louis and Adelaide Simonet. Rosemond Wilkinsonlater Mrs John Mountain — was the daughter of a Mr Wilkinson, a slack-wire and tightrope performer, and his wife, a dresser and actress. Her siblings were the performers Caroline, Frederick, and George Wilkinson, and she may have been the niece of the rope dancer, Isabella Wilkinson. ${ }^{26}$ And the last figure, Maria Romanzini, who had various romantic stories attached to her antecedents, was born in Caen, the daughter of Alexander Tersi, a strolling musician from Rome, and Catherine Zeli, from Florence. She was brought to London, and made her English debut at

23 Ibid. $\quad 24$ Gazetteer and New Daily Advertiser (31 October 1782).

25 Listed as 'Miss Romanzini' in the libretto; Maria Theresa Catherine, Mrs George Bland, née Tersi, but also known as 'Romani': Philip H. Highfill, Kalman A. Burnim, and Edward A. Langhans, A Biographical Dictionary of Actors, Actresses, Musicians, Dancers, Managers and Other Stage Personnel in London, 1660-1800, 16 vols (Carbondale: Southern Illinois University Press, 1973-93), 2:162-9 (1973).

26 Ibid., 10 (1984):346. 
four years old. If the best 'graduates' were offspring of performers, then the question might be asked whether such indenture was necessary, given that they could have learnt the trade regardless, but it does nevertheless point to three things. Firstly, it suggests that these performers had confidence in the Royal Circus and in Dibdin to educate their children. Secondly, it demonstrates yet again the importance of the networks represented by the generations of theatrical and musical families, networks which secured jobs and roles, and which ensured some continuation of theatrical authority. Thirdly, not only were such performances by entire casts of children a novelty (almost) exclusive to the Royal Circus, but there is no doubt that they were an additional selling point for at least a certain section of the audience who could then witness performances by the children of their favourite stars of the legitimate theatre.

\section{PROGRAMMES, WORKS, GENRES}

The Royal Circus was a fundamentally collaborative venture and responsibility for the bills was split between the three departments: Dibdin had control of the burlettas; Hughes, a 'strong man' as well as an equestrian performer, dealt with the horses and equestrian acts; and Giuseppe Grimaldi (c.1713-88) (brought in later by Dibdin) trained the children and looked after the dances. ${ }^{27}$ We know little of how these activities were coordinated on a day-to-day basis, and not much more about the organization of the performances, although the following announcement gives some impression of the nature of the equestrian events:

This and every Evening, the Royal Circus and Equestrian Academy will open with a regular and compleat [sic] Series of Equestrian Exercizes; containing a well-digested and perfect System of all the necessary Rules for managing and rendering tractable that noble Animal the Horse, from placing the Foot in the Stirrup, to performing the most difficult and astonishing Equilibriums... To separate the different Species of Riding, and to recruit the Strength of the Performers, in order to render their Exertions more worthy publick Notice, the Horsemanship will be interspersed with picturesque and allegorical Exhibitions. ${ }^{28}$

Dibdin's efforts were clearly concentrated in the 'picturesque and allegorical Exhibitions', which consisted of a variety of works and genres. These were central to Dibdin's uniting the business of the ring and the stage. Some of these scenes contained some action, others none at all. Their themes were often notions of national identity; they included, for instance, a set of monuments of deceased heroes, and the cavern of Merlin, the latter a topos that dated back to the

27 Grimaldi appears to have been a bully and sadist who locked the children 'into a specially built cage that was pulled forty feet into the fly-tower and left to dangle for hours above the stage'. He also choreographed a libellous and potentially obscene ballet called The Quakers, which was stopped with a court injunction, and there were parental complaints, which ended in the local magistrates ordering 'a complete investigation into the morals of the place'. McConnell Stott, Joseph Grimaldi, 16.

28 Daily Advertiser, (20 December 1782). 


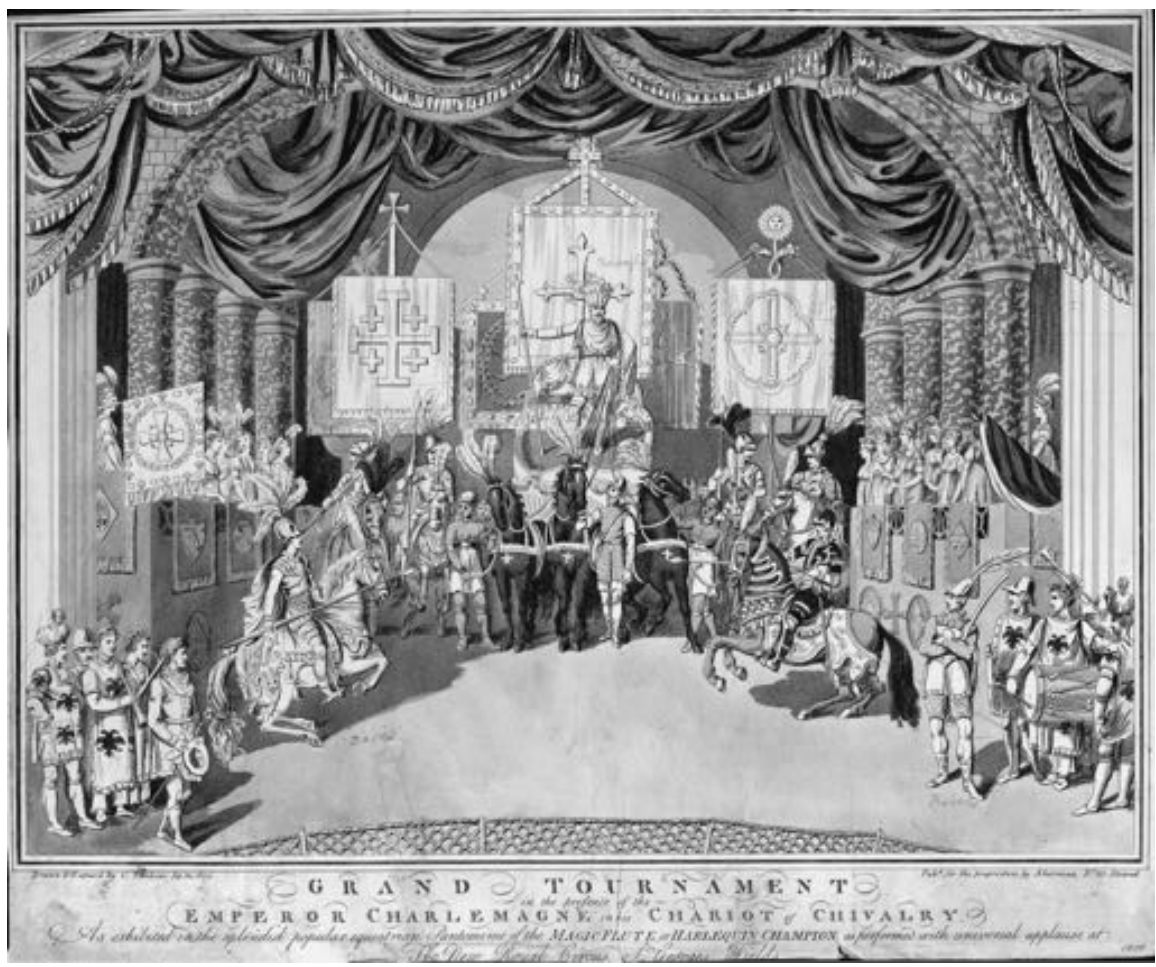

Figure 3.3. Charles Tomkins, Grand Tournament, in the presence of the Emperor Charlemagne in his chariot of chivalry. London, 30 September 1800. Engraving. (C) Trustees of the British Museum.

1730 s. ${ }^{29}$ There is no contemporary visual record of these shows, but an illustration of the 'grand Tournament' scene from The Magic Flute, or, Harlequin Champion for a Royal Circus show in 1800 (Figure 3.3) conveys an idea of the type of staging that might have been found. The performers are all in character, that is, dressed (in this case) as members of Emperor Charlemagne's retinue; the stage, which has a box set with balconies, is draped with banners, shields, and other emblems of state; and there is onstage music consisting of a bassoon, a trumpet, and a military drum. There is a fourth instrument, which appears to be an 'antique' wind instrument, possibly a shawm, giving a vague feeling of historicity to the scene. Given this is the Royal Circus, it may be assumed that the horses are real.

Such displays were obviously spectacular; here, the scene is about to erupt into a joust between the two knights, one on a white horse, the other on a black one. But like all spectaculars, they had the capacity to go awry in performance. A humorous account of one disaster gives some insight into what might be expected

29 Michael Burden, 'Purcell's King Arthur in the 1730s', Restoration: Studies in English Literary Culture, 1660-1700 34/1-2 (2010-11): 117-38. 
from one of the numerous allegorical scenes mentioned as having been included in the evening's bills:

A Circumstance occurred on Monday Evening at the Royal Circus, which it is to be hoped may not prove prophetic. Among other Questions to be resolved by allegorical and other Transparencies, the supposed Inhabitant of the new planet called the Georgium Sydus, demanded of the Genius of the Enchanted Bower 'When the Honour of England would decay?' Upon this, the Word NEVER became conspicuously illuminated: The Painting, however, was hardly in View, when, from some Accident in the Machinery, it fell on one Side; but it was presently replaced.-Let us hope that the Honour of Old England is not fallen irrevocably, but, notwithstanding it must be allowed there has been a Disarrangement in the Economy of the State Machinery, that those who are now to conduct the Business behind the political Curtain, will have the Address to repair all past Defects, and to restore Old England to that State of Magnificence and Splendour which once excited the Admiration and Envy of the whole World. ${ }^{30}$

The 'Disarrangement in the Economy of the State Machinery' referred to was the severe undermining of the government's majority in parliament following the negative public reaction to the generous terms offered by Prime Minister Lord Shelburne in the 'Provisional Agreement', part of the preliminary negotiations for peace between Britain and the American colonies, which had been signed on 29 November 1782. After this date, it was clear to the British public that the government had ceded independence to the American colonies and granted them huge tracts of land. Despite some small consolatory victories at sea, British imperial pride was severely dented. ${ }^{31}$ Such circumstances reveal the ways in which, even if not entirely successful in their execution, the Royal Circus spectaculars were designed to capitalize commercially on moments of heightened public political excitement.

These scenes and the equestrian shows appear to have been accompanied by music, and the indications are that there was more music involved than even the programmes that appeared in the newspapers suggest. However, the nature of both types of show-ad-libbed, relying on variable theatrical timings, and probably adjusted to take into account audience reactions on any particular night-implies that apart from set pieces, such as songs, which do survive, Dibdin's music, otherwise lost, was generic and flexible, enabling him (and the orchestra) to respond to the actual performance.

Of the pantomimes, much might be gleaned from the full printed description of Dibdin's Arabian-themed The Magic of Orosmanes; or, Harlequin Slave and Sultan. Dibdin confines the Arabian characters to the short sung scenes of the work, while Harlequin and the Clown mime the narratives of the other scenes which were then written out in full in the book. As is often found in this type of pantomime, the characters, which include a dwarf, a dragon, and other grotesques in the different

30 Public Advertiser (25 December 1782).

31 See Jonathan R. Dull, 'Diplomacy of the Revolution, to 1783', in Jack P. Greene and J. R. Pole (eds), A Companion to the American Revolution (Oxford: Blackwell, 2008), 359-60. 
scenes, do not connect until the final denouement. ${ }^{32}$ Another such pantomime dates from after Dibdin's departure, although before his last work for the Circus. This was The Vicissitudes of Harlequin, which had recitatives and arias by Mr Brookes, scenery by Michael Novosielski, and dresses and decorations by Signor Lusina. ${ }^{33}$ Its importance lies in the fact that the management was moving to improve the standard of the music and production; here the sets were designed by Novosielski, a scene designer associated with the Opera House. A similar situation pertains to the ballets, which included stories on classical legends such as Admetus and Alceste and Bacchus and Ariadne. The advertised dancers include names of performers who also appeared at the Opera House, and these offerings seem to have been consistently successful, perhaps part of a deliberate move to upstage rivals such as Astley. ${ }^{34}$

A key part of any theatre's success was being alive to the fluctuating demands and tastes of the public. The popular Mandarine; or, The Refusal of Harlequin was 'laid aside' for a week to ensure the bills contained adequate variety. However, the public had clearly become attached to the 'Temple of Chinese Fire' it contained, so the management staged this separately, tacked on to the ballet of Admetus and Alceste. ${ }^{35}$ The programmes also included commemorations of royal events in shows that often had illuminations and fireworks; in 1783, for one show, the management decorated the three centre windows of the building with transparencies, and provided 'a large quantity of rockets, air balloons, pots debrins, l'aigrettes, and other Italian air works'. ${ }^{36}$ Such displays were typical ploys found at the minor theatres such as the earlier Goodman's Fields, ${ }^{37}$ where the managements, primarily engaged in drawing the public's attention, were not interested in whether the occasion itself was of importance. And this one was no exception: the event being marked here was 'the Anniversary of the birth-day of the Prince of Wales, who entered the $22 \mathrm{~d}$ year of his age', ${ }^{38}$ which, for the sake of 'rejoicing', was made a general occasion of the sort that the theatre management was keen to exploit.

Dibdin's name is not headlined in the bills until after 18 October 1783; here it was announced that the music was 'conducted in the immediate inspection' of Dibdin. ${ }^{39}$ The music that accompanied the works mentioned above would have been incidental music, and sometimes improvised; much of it was probably not tied to any individual show. His more formal works for the Circus included burlettas, intermezzos, serenatas, and pantomimes, although not operas, the designation of

32 Charles Dibdin, The Magic of Orosmanes; or, Harlequin Slave and Sultan: a Pantomime, Drawn from the Arabian Legends (London, 1785), 14.

33 Morning Chronicle and London Advertiser (22 June 1784).

34 Morning Chronicle and London Advertiser (19 November 1783). The connections extended further; see the Morning Post (28 February 1785), where the tradesmen who publicly supported Hughes included Thomas Luppino, '36 years taylor at the Opera House'.

35 Parker's General Advertiser and Morning Intelligencer (11 November 1782).

36 Gazetteer and New Daily Advertiser (11 August 1783).

37 See, for example, Michael Burden, 'The Wedding Masques for Anne, the Princess Royal', Miscellanea Musicologica 17 (1990): 87-113.

38 General Evening Post (9-12 August 1783).

39 See, for example, Public Advertiser (24 October 1783). 
which would have drawn the attention of the patent theatres eager to protect their license. The term 'intermezzo' was used to describe the small Italian operas that had their origins in the comic scenes between the acts of opera seria; it came into use in London in about 1750. Confusingly, these works were also called 'burlettas': the Giordani Company largely responsible for performing them was described as a 'burletta company', and the 1759 and 1771 London-printed sources of La Serva Padrona referred to it as a 'burletta'. ${ }^{40}$ However, in the 1760 s, 'burletta' was then the designation given to a British imitation commissioned by Lord Mornington; here the work became an all-sung piece using mythological figures and a classical story. The first work in this new genre, Kane O'Hara's Midas, was staged in London in 1766; other works such as The Golden Pippin and The Judgment of Paris followed, including an important one by Dibdin, Poor Vulcan! (1778). ${ }^{41}$ The genre then ceased to be thought of as all-sung, when according to George Colman the Younger, the burlesque tragedy Tom Thumb, revived at Covent Garden in 1780 , was 'inadvertently announced by the managers ... as a burletta'. ${ }^{42}$ As we find in one of Dibdin's pieces for the Circus, The Graces, such a designation could be combined with others, this one being called an 'intermezzo of demi-character', thereby harnessing the term intermezzo to refer to its general function and possibly to its single act, and employing the dance term 'demi-character' to suggest the telling of a story through the spoken text. ${ }^{43}$

'Burletta' was, then, used to describe works such as the above-mentioned Cestus which were a kind of mythological burlesque. Dibdin's score for Cestus is more sophisticated than one might suppose from the context of the work. It consists of three da capo arias for Romanzini, and one each for Seymour and Wilkinson, through-composed airs for Sestini and Seymour, multi-versed airs for Romanzini, Seymour, and Wilkinson, and a da capo duet for Romanzini and Wilkinson as the finale. ${ }^{44}$ Da capo arias are not what one would expect at the Circus or in a work sung by children; indeed, it might be said to be pretentious. However, the score and title page of the Cestus libretto both designate the work a 'serenata', which might suggest that Dibdin was trying to elevate the work above a group of mere ditties. In fact, the term in eighteenth-century London was usually used to describe works that were serious, often having an occasional function. It did not otherwise imply any particular traits, with one exception: it meant that the work, even if performed in costume, had no action. This use of the term in London originated in Handel's

40 See Richard G. King and Saskia Willaert, 'Giovanni Francesco Crosa and the First Italian Comic Operas in London, Brussels and Amsterdam, 1748-50', Journal of the Royal Musical Association 118/2 (1993): 246-75; The Favourite Songs in La Serva Padrona (London, 1759), GB-Ob Harding Mus. H 5 (6); and The Servant Mistress (London, 1770), GB-Lbl 11630.d.4.(18).

41 Fiske, English Theatre Music, 318-22.

42 Richard Brinsley Peake, Memoirs of the Colman Family, Including their Correspondence (London, 1841), 398, and see 396-400 for an extended discussion of the matter; see also Michael Burden, 'The Writing and Staging of Georgian Romantic Opera', in Swindells and Taylor, Handbook of the Georgian Theatre, 424-41.

43 Charles Dibdin, The Graces, an Intermezzo in One Act. As it is Performed at the Royal Circus, in St. George's Fields (London, 1782).

44 Charles Dibdin, The Cestus: a Serenata as Performed at the Royal Circus (London, [1783]). 
performances of his masque, Acis and Galatea (1718), which had been pirated by the English Opera Company at the Little Haymarket theatre in 1732; Handel's response was to perform it with 'no Action on the Stage' but where 'the Scene will represent, in a Picturesque Manner, a Rural Prospect, with Rocks, Groves, Fountains, and Grotto's; amongst which will be disposed a Chorus of Nymphs and Shepherds, the Habits and every other decoration suited to the Subject'. ${ }^{45}$ Handel's wheeze stuck, and not only was Acis and Galatea then frequently performed under the label of a 'serenata', but William Boyce composed what became the best-known serenata of the eighteenth century, Solomon, which was performed in this manner. When Dibdin composed works in this genre, then, he was writing in a mode well understood by his audience, and of course, a work 'with costume and no action' could be utilized for the allegorical scenes, and had the added advantage that it was more easily performed by children. Dibdin's approach represented an attempt to link the music at the Circus with established and well-regarded precedents, while giving them a novel twist, through the use of children or their combination with equestrian events.

\section{FAILURE: THE ROYAL CIRCUS EPITOMIZED}

As the evidence above suggests, Dibdin was instrumental in building the Circus into a competitive, innovative form of public entertainment. Yet his time there ended in quarrels, arguments, and litigation. Never at a loss with a pen in his hand, Dibdin took his arguments into the public realm via a pamphlet, The Royal Circus Epitomized. A highly readable work of vitriol and self-justification, it is a more interesting and immediate account-including more (probable) facts-than the narrative in the later and more considered The Professional Life of Mr Dibdin. The dedicatory text of the The Royal Circus Epitomized was, however, far from the typical flattery one might expect to find in such circumstances. Dibdin denounces its dedicatee, William Davis, boldly claiming that it will be impossible for others to trust Davis in business after his 'despicable treatment' of the composer. This is followed by an advertisement, a 'Humble Petition', two epigrams, 'A Moral Comparison', 'A dispute between Jew Ball and Jew Friendship', and the Equestrian Creed, which describes the proprietors (a merchant, a surgeon, a sportsman, and an attorney) as being ignoramuses: 'the stupidity is equal, the absurdity eternal'. ${ }^{46}$ The parodied literary forms in which the material was expressed were all part of Dibdin's attack, and the contents of his venomous document thus reveals much about the failure of Dibdin, Hughes, Grimaldi, and the proprietors to work together successfully in a line of business that demanded collaborative methods of production.

One of the key lines of dispute was the question of licences. The Royal Circus was, of course, outside the jurisdiction of the Lord Chamberlain, but it was not out of range of the Surrey magistrates, who gave permission for such venues in this part

45 Daily Post (5 June 1733).

46 Charles Dibdin, The Royal Circus Epitomized (London, 1784), xi. 
of London. Among the important information Dibdin reveals is that he supported opening the Circus without a licence. The problem the promoters faced was that the Magistrates met on such matters only at Michaelmas, which had just passed. Dibdin, clearly anxious about securing the competitiveness of the new Circus, claimed that to wait would mean that the Circus would be unable to capitalize on the 'universal curiosity' about the new venture, that the 'seeds of opposition' to the application were already sown, and that the arena was already gaining a (false) reputation as a venue for rope-dancing and tumbling, drinking and gambling. ${ }^{47} \mathrm{In}$ essence, Dibdin's argument was that if the theatre opened quickly and was seen to be run with propriety, then a licence would be forthcoming. What he claimed to fear was what in fact happened: the building work slowed up, the proprietors applied at a late stage for a licence, which was then refused (according to Dibdin) as a result of false and scandalous reports spread by the Circus's rivals. The theatre then opened anyway on 4 November 1782, not only without a licence, but with a licence having been refused; by 15 November the magistrates had closed it down.

As all the personnel were already engaged by the Circus, Dibdin proposed that the theatre open again with what he called 'a mode of amusement unlike anything we had done before'; these were the allegories discussed above. While in counsel's opinion this was fine, the magistrates disagreed, and the performances precipitated Hughes's arrest on 27 December 1782. Found innocent, Hughes then reopened the theatre without a licence, and managed it successfully through to September 1783. However, when the licence was granted for the following season starting 18 October, only Hughes's name seems to have been associated with it, but, according to Dibdin, the season went well despite the costs associated with bringing out his new Fairy World programme. ${ }^{48}$ The theatre closed at the beginning of December, and then reopened at Christmas. Dibdin opposed this reopening on the grounds that nothing was new, emphasizing the importance of novelty to success; in fact, as he feared, it caused 'universal dissatisfaction', and Dibdin was blamed for the fiasco.

This narrative is a counterpoint to another key line of dispute: the failure of the proprietors to come to any contractual agreement with Hughes and Dibdin over their payments. Much of the information provided by Dibdin is rudimentary, but in essence, the proprietors seem on several occasions to have changed the nature of the profit-share they proposed to both Dibdin and Hughes, each time on the basis of their own increasing expenses. However, for the successful run from 15 March to 27 September 1783, Dibdin does tell us clearly that although the proposed memorandum never materialized, he and Hughes did in fact receive a quarter of the profits every Saturday. ${ }^{49}$ But he was pained to discover that 'neither Mr Hughes nor myself were to have the liberty, without the consent of the committee to publish any book'. ${ }^{50}$ Without the books, Dibdin could gain no extra income of the kind that was usually part of a librettist's remuneration: as he said, 'the prohibition of publications struck particularly hard' with him. ${ }^{51} \mathrm{He}$ believed what he was told: that the clause was aimed at curbing Hughes, who might publish words 'to the
47 Ibid., 11.
48 Ibid., 35.
49 Ibid., 22.
50 Ibid., $25-7$.
51 Ibid., 25. 
disgrace of the concern', 52 and was assured that the words and music of his pieces were not implied in the clause. To compound the problem, Hughes attempted to seize the advantage and drive Dibdin out of the theatre by persuading his creditors to pursue him. These financial tensions were perhaps an endemic feature of collaborative methods of production, which left some feeling the profits of their hard work were disproportionately benefiting their colleagues. Dibdin later saw conspiracy behind every move: 'While the leech Hughes, was sucking the blood of the proprietors, and fastening on the concern, the serpent Grimaldi, was coiled up till a proper opportunity arrived to seize the management. ${ }^{53}$ In the end, Dibdin lost the battle; by the time of the winter closure on 7 February 1784, Dibdin was gone, voted out of the Circus by the proprietors, William Davis, George Grant, Richard Harbourne, Thomas Bullock (for Sir John Lade), and Thomas West (for Mr West). ${ }^{54}$

\section{ENVOI}

Yet, remarkably, Hughes and Dibdin did attempt to run the Royal Circus again as a partnership: Dibdin claimed that Hughes approached him some time in early 1785, and they laid claim to the institution from February. ${ }^{55}$ After a month's titfor-tat advertising over the matter, on 19 March an agreement was reached between the proprietors, and Hughes and Dibdin as managers, ${ }^{56}$ and the Circus opened for business again on 28 March. But despite the advertising of programmes 'on a new plan and infinitely superior to things before attempted', 57 the bills themselves looked similar, and although things went well for about five weeks after opening, the situation between the two men rapidly deteriorated. Dibdin then quit the Circus for good.

This final episode in Dibdin's connection with the Royal Circus is a telling sign of the importance of collaboration to the success of such ventures. Since it was based on the principle of miscellaneous mixing of forms and genres of entertainment, without Dibdin's musical expertise, the theatre had evidently failed to thrive. Dibdin's time at the Circus opens up a window into the competitive dynamics driving the rapid expansion and development of the minor theatres in this period. London was beginning to be able to support a range of theatres and spaces of commercial entertainment, beyond its traditional theatres royal and the Opera House, but it was a tough and demanding market in which to operate. Securing the edge over the competition-whether through a more advantageous location, a more elegant building, grander spectacle, more elaborate music, enticing novelties, or a more entertaining mix of genres and forms — was vital to the way in which the Royal Circus project was conceived and run. Such strategies for success in the world

\footnotetext{
52 Ibid. $\quad 53$ Life, 1:111. 54 Dibdin, Royal Circus, 22.

55 See Morning Chronicle and London Advertiser (25-26 February 1785).

56 Morning Chronicle and London Advertiser (21 March 1785).

57 Public Advertiser (23 March 1785).
} 
of the minor theatres occur again in the life of Charles Dibdin the Younger, whose later management of Sadler's Wells Susan Valladares explores in Chapter Nine of this volume.

This narrative does, however, also highlight some of the pitfalls lurking for the unwary theatrical entrepreneur: the vagaries of ad-hoc licensing laws in areas beyond the traditional Cities of London and Westminster; tensions over profit shares and ownership of works; and disagreements over management, exacerbated by differences in personal temperament. Eventually, of course, Dibdin found a solution to this problem in the one-man show, but, as noted in the Introduction to this volume, we should perhaps resist this all-too-teleological interpretation offered by The Professional Life. Instead, the Royal Circus episode was inspired by and drew upon the collaborative methods of production Dibdin had developed during his early career working in various capacities for the London theatres. Dibdin's representation of it as flawed, dissatisfying, and problematic is strongly coloured by his later success as a solo performer. But while Dibdin became progressively less enamoured by the collaborative methods of the minor theatres, and his complaints were increasingly echoed by a range of early-nineteenth-century critics (as Jim Davis shows in Chapter Ten of this volume), this style of production-innovative, varied, entertaining - continued as the basis of the minor theatres' success far into the nineteenth century. 


\title{
Interlude 1
}

\section{Dibdin and Robert Bloomfield Voicing the Clown in Town}

\author{
Katie Osborn
}

Charles Dibdin frequently took up an important borderland for the late-eighteenthand early-nineteenth-century writer: the intersection between the metropolis and the countryside; between civilized, modern ways of speaking (which he eagerly parodies) and the real language of men (which he gleefully mimics). His song 'Joltering Giles', for example, stages an encounter between a 'sturdy clown' and two gentlemen from the city. The farm labourer is introduced with comic archaic language: 'HARK! with what glee yon sturdy clown, / Reasons, remarks, and sows. ${ }^{1}$ But when he speaks to the city men, he uses a bouncing rustic dialect:
A vrend to all the country round,
My labours all regale:
Twas I the barley put i' the ground,
That brew'd th' exciseman's ale;
The wheat I zow with even hand,
To thousands shall give bread:-
Why there's no king or 'squire o' the land
Zo many mouths ha' ved.

Robin Ganev connects this image of the helpful rustic to how rural life is depicted in many ballads, including Dibdin's. ${ }^{2}$ The 'clown' also appears in much of the poetry of Robert Bloomfield, a contemporary labouring-class poet who admired Dibdin's songs and poetry. His poem The Farmer's Boy portrays another, very similar Giles, describing the farm boy's work as 'constant chearful servitude'. ${ }^{3}$ In both men's works, the term 'clown' invokes the minstrel-like persona of the uneducated labourer many consumers of songs and poetry embraced-a figure

1 'Joltering Giles', from one of Dibdin's Sans Souci Entertainments: The Selected Songs of Charles Dibdin (London, 1845), 591. Interestingly, the 1839 version is not written in dialect: The Songs of Charles Dibdin, 2 vols (London, 1839), 1:161-3.

2 Robin Ganev, Songs of Protest, Songs of Love: Popular Ballads in Eighteenth-Century Britain (Manchester: Manchester University Press, 2010), 112.

3 The Farmer's Boy, in Robert Bloomfield, Selected Poems: Revised and Enlarged Edition, ed. John Lucas and John Goodridge (Nottingham: Trent Editions, 2007), line 30. 
'deferential, dependent and ignorant'. ${ }^{4}$ The project of revising this deferential 'clown' had a personal appeal to Dibdin and Bloomfield, both largely self-taught, and both invested in their personal narratives of natural genius. In both Dibdin's and Bloomfield's works, the figure of the clown conjures the intersections of countryside and metropolis, artifice and nature. The rustic, with his innate sense and his appearance of candour, becomes an attractive image of riddling satire, a figure thrust into-and by nature outside of - dominant metropolitan culture.

Anticipating David Kennerley's description of Dibdin's self-fashioning in Chapter Five, this study proposes that Dibdin and Bloomfield used dialect and rusticity in their works to assert themselves as independent comic voices. Both immigrants to London, Dibdin and Bloomfield used country voices to assert themselves as more 'plain-speaking, open, [and] independent' than their city neighbours. Born in Suffolk, Bloomfield moved to London as an adolescent to become a shoemaker, and eventually made a tenuous living from his writing. Dibdin likewise moved to London at a young age, and lived in many ways a rather hardscrabble actor's life. Asserting themselves as natural and sincere, both men also clung fiercely to their reputations as autodidacts. Dibdin claimed in his autobiography, 'The music I have was strongly in my mind from my earliest remembrance, and I know that no master could at any time have been of the least service to me. It lay quietly a hidden spark, which, in the country, found nothing ardent enough to vivify it; but, coming in contact with its proper fuel, the different performances in town, it at once expanded, and nothing could keep it within bounds. ${ }^{5}$ Bloomfield similarly found his muse while living in the city, though again and again he returned, like Dibdin, to rural scenes and rustic characters. Finally, both men were deeply interested in ways of representing the language of the countryside to London audiences, an aspect of Dibdin's work that has been overlooked by many of his modern readers. In this respect this interlude is a contribution to a growing body of work on dialect as an often ambivalent political tool in the Romantic period. Stephen Dornan, for example, argues that dialect texts may appear simple and even clownish, but they simultaneously have a special potential to disorient and estrange readers. ${ }^{6}$ There is almost always, Dornan argues, a correlation between dialect use and 'oppositional perspectives on politics and society'. ${ }^{7}$ Dibdin and Bloomfield's rustic types, however, do not represent a clear radical or levelling politics so much as they offer an opportunity for the poet or songster to assert himself as an independent and creative authority. As Harriet Guest describes at length in Chapter Eight of this volume, Dibdin (and Bloomfield) asserted their virtuosity through the coining of various voices, perspectives, and rhythms.

\footnotetext{
4 Mark Freeman, 'The Agricultural Labourer and the "Hodge" Stereotype, c.1850-1914', Agricultural History Review 49 (2001): 172-86, 174.

5 Life, 1:21-2.

6 R. Stephen Dornan, 'Radical Politics and Dialect in the British Archipelago', in John Kirk, Andrew Noble, and Michael Brown (eds), United Islands? The Languages of Resistance (London: Pickering \& Chatto, 2012), 169-79, 172.

7 Ibid., 170.
} 
Bloomfield and Dibdin's careers bring into focus the fact that music, a predominantly performative mode of expression, and poetry, a predominantly textual mode, were still closely tied in the late-eighteenth-century world. Rising literacy levels, greater access to print, and increased travel between the metropolis and the countryside (and among the four nations) meant that by the end of the eighteenth century, traditional 'oral' rural culture and metropolitan print culture overlapped as never before. ${ }^{8}$ Thomas Percy's Reliques of Ancient English Poetry (1765) capitalized on this intersection and exerted a powerful influence over Dibdin, Bloomfield, and the development of what we now consider mainstream Romantic poetry. One reason for the success of Bloomfield's poetry in the late-eighteenth- and early-nineteenthcentury literary market was its savvy borrowing from both high cultural, neoclassical works such as Stephen Duck's Thresher's Labour and James Thomson's The Seasons and, simultaneously, very modern works such as Dibdin's songs and (their professed antiquity notwithstanding) Percy's ballad collections. Almost everything Bloomfield published was classified by the poet as 'songs', some with directions for accompanying music.' In addition, Bloomfield fiddled, versified 'Hook's music lessons', attended London entertainments, and wrote a musical entertainment himself. ${ }^{10}$ His first and most successful long poem, The Farmer's Boy (1800), and his later rural ballads profess to tell 'untold tales': histories from below that are connected with 'real life' because of his rural labouring experience. ${ }^{11}$ Many of Dibdin's impersonation songs_-such as 'Joltering Giles', 'The Gardener', 'The Waggoner', 'The Tinker', and 'The Woodman'-find their humour in this appeal to authenticity, especially when the songs juxtapose the old-fashioned rustic and the modern city man. Which, Dibdin seems to ask, is the more absurd: the foppish spark, or the riddling bumpkin?

Bloomfield was an avid and critical attendee at London entertainments of various kinds, as several comments in his letters and Remains show. He invokes his affinity with Dibdin in the preface to his last volume of poetry, May-day with the Muses (1822). Bloomfield writes, 'I never found any thing to strike my mind so forcibly as the last stanza of Dibdin's "Sailor's Journal" ... This, to my feelings, is a balm at all times; it is spirit, animation, and imagery, all at once.' ${ }^{12}$ Bloomfield may have seen Dibdin perform it: he moved to London at the age of fifteen in 1781, and lived

8 Philip Connell and Nigel Leask, 'What is the People?', in their Romanticism and Popular Culture in Britain and Ireland (Cambridge: Cambridge University Press, 2009), 9-21.

9 'The Man in the Moon' and 'Irish News' were both set to popular tunes: The Works of Robert Bloomfield (London, 1867), 318, 320.

10 Bloomfield's last publication, Hazelwood Hall, was a five-act play for which he composed several songs. At some point Bloomfield also set words (on rural themes) to several of Hook's music lessons. He may have been inspired, or vice versa, by John Kelly's work, advertised in the British Critic in 1814. Kelly's verses, unlike Bloomfield's, are purely didactic: 'Thus from C, if we move to the Fifth degree higher, / By such transposition, one Sharp we acquire' (New Series, 2:434). Compare to Bloomfield's 'For Hook's Ninth Lesson': 'Down in the forest / Where the hazel boughs are spreading, / Where sunbeams gleaming play' (Works, 314).

11 For a discussion of the way rural and labouring-class balladeers used labour to legitimize their expressions, see Ganev, Songs of Protest, 112.

12 Bloomfield, Selected Poems, 138-9. Bloomfield's editors wrongly identify the author of 'The Sailor's Journal' as Dibdin's son, Thomas John Dibdin: ibid., 192. 
there consistently after $1784 .{ }^{13}$ The 'Sailor's Journal' was composed for and performed at Dibdin's Royal Circus entertainment Will o' the Wisp in $1785 .{ }^{14} \mathrm{It}$ is tantalizing to imagine Bloomfield attending one of Dibdin's private theatricals, for the poet seems to have little relish for large public venues. His satire 'A Visit to Ranelagh', occasioned by the Peace of Amiens, dryly depicts the response a rustic 'clown' might have to urban sights—a situation Dibdin may himself have witnessed in his tenure as musical director at Ranelagh in the late 1760s. Bloomfield's rustic speaker is unimpressed with urban spectacles:

A thousand feet rustled on mats,

A carpet that once had been green;

Men bow'd with their outlandish hats,

With corners so fearfully keen!

Fair maids, who at home in their haste,

Had left all clothing else but a train,

Swept the floor clean, as slowly they pac'd,

And then—walk'd round and swept it again.

The music was truly enchanting!

Right glad was I when I came near it;

But in fashion I found I was wanting:-

'Twas the fashion to walk and not hear it!

A fine youth, as beauty beset him,

Look'd smilingly on the train;

'The king's nephew', they cried, as they met;

Then-we went round and met him again. ${ }^{15}$

Each more-or-less anapaestic stanza ends with the same refrain, 'and then we went round it again' - a pun on the round architecture of Ranelagh. 'What wonders were there to be found', the poet asks, 'That a clown might enjoy or disdain?' The rural speaker compares metropolitan spectacles to rural ones: a bell rings, announcing not the end of a workday but 'new pleasures'; people cover the yard as 'a white flock'; and blue fireworks resemble rain. In the end, the rustic finds the practice of urban life repetitive and empty; the wonders of the king's head, the women's dresses, and the music all lose their allure on a second viewing (and third, and fourth).

Bloomfield's poem shares much with Dibdin's song 'The Bumpkin in Town'. Like Bloomfield's, Dibdin's bumpkin is unconcerned with rank, placing himself and the man of a higher status on even footing:

What tho' I be a country clown?

For all the fuss you make,

One need not to be born in town

13 Lucas, Introduction to Bloomfield, Selected Poems, 15. It is more probable that Bloomfield either owned or borrowed a printed copy of the poem, since he quotes several lines of it (ibid., 139).

14 Edward Rimbault Dibdin, 'A Bibliographical Account of the Works of Charles Dibdin', Notes and Queries 9 (31 May 1902): 422.

15 'A Visit to Ranelagh', Works, 198-200. 
To know what two and two make.

$$
\text { ... }
$$

Then do not be so proud, d'ye see,

It 'ent a thing that's suiting;

Can one than t'other better be,

When both are on a footing? ${ }^{16}$

Here and in many other poems, the riddling rustic seems to triumph over slow-witted, fashion-obsessed metropolitans. In fact, Dibdin poked fun at both bumpkins and citydwellers. Dibdin's 'The Joys of the Country' is perhaps his clearest illustration of both the troubles of country life and the absurdity of pastoral nostalgia:

Where nature to smile when she joyful inclines,

And the sun charms us all the year round when it shines:

...

There we pop at the wild ducks, and frighten the crows,

While so lovely the icicles hang to our clothes. ${ }^{17}$

For Bloomfield, rural people would always be what Dibdin called (referring to the Royal Navy, that remorselessly modern institution) 'the natural bulwark of their country'. ${ }^{18}$ In most of Dibdin's songs, however, rural labour and rural culture are merely given lip service as important parts of Englishness, due in part perhaps to what Judith Hawley describes in Chapter Six of this volume: Dibdin's attempt to assert an independent but ultimately masculine art. That his bumpkins are nearly always male does not mean they are not also ultimately dismissed as humorously naive and backwards, when compared to the equally ridiculous - but thoroughly moderncity man. 


\title{
4
}

\section{The Detail is in The Devil \\ Dibdin's Patriotism in the 1780 s}

\author{
David O'Shaughnessy
}

From the very outset of the eighteenth century, newspapers were seen as central to the activities of the recent mixed constitutional arrangement in Britain and one of its organizing principles of 'liberty', however woollily that term might be defined. The Daily Courant was London's first daily newspaper from March 1702 and outlined its vision in one of its earliest issues:

It will be found from the Foreign Prints, which from time to time, as Occasion offers, will be mention'd in this Paper, that the Author has taken Care to be duly furnish'd with all that comes from Abroad in any Language. And for an Assurance that he will not, under Pretence of having Private Intelligence, impose any Additions of feign'd Circumstances to an Action, but give his Extracts fairly and Impartially; at the Beginning of each Article he will quote the Foreign Paper from whence 'tis taken, that the Publick, seeing from what Country a piece of News comes with the Allowance of that Government, may be better able to Judge of the Credibility and Fairness of the Relation: Nor will he take upon him to give any Comments or Conjectures of his own, but will relate only Matter of Fact; supposing other People to have Sense enough to make Reflections for themselves. ${ }^{1}$

The Courant's intention to offer impartial information and to refrain from introducing personal bias, its engagement with the events of other European countries, and, most importantly, its declaration of faith in its readership 'to have Sense enough to make Reflections for themselves' mark the nascent newspaper industry as one which was conceived of as central to the experience of the Enlightenment in Britain. These sentiments were voiced as print culture flourished and were only heightened in the wake of the John Wilkes affair. ${ }^{2}$ But the 1780 s was arguably the most significant decade of activity and growth for London—and thus British—newspapers. ${ }^{3}$ That

1 Daily Courant (19 March 1702).

2 See Arthur Aspinall, Politics and the Press, c.1780-1850 (London: Home \& Van Thal, 1949), 35-6, and Kathleen Wilson, The Sense of the People: Politics, Culture and Imperialism in England, 1715-1785 (Cambridge: Cambridge University Press, 1995), 206-36.

3 Regional newspapers were very dependent on London newspapers for material even if they were highly selective and followed their own political lines. See Hannah Barker, Newspapers, Politics, and Public Opinion in Late Eighteenth-Century England (Oxford: Oxford University Press, 1998), 95-8 and passim. 
decade saw a number of important daily newspapers commence publication: the Morning Herald and Daily Advertiser (1780), the Daily Universal Register (1785, which became The Times in 1788), and The World (1787). But, more significantly, as documented by Lucyle Werkmeister, newspaper practices changed markedly over the decade as titles proliferated. Werkmeister suggests that the 1770s and 1780s saw the decline of the advertiser model and the concomitant rise of the 'scandal sheet'. Werkmeister also documents the increasing importance of 'puffing' and newspaper subsidy by persons of quality and, in particular, by political parties. ${ }^{4}$

Werkmeister's conclusions have been challenged more recently by Hannah Barker, who argues that the newspapers were much more independent of political subsidy than Werkmeister allowed. For Barker, the economics of newspapers were paramount: the profit motive meant that outright political control of press titles by political groupings was most unlikely. Rather, consistent political lines taken by particular newspapers were arrived at with a degree of independence and aimed at maintaining a loyal readership: 'The need to maintain extensive distributions meant that newspapers were dependent not upon political patronage, but upon their appeal to readers. The political debate which took place in the capital's press was thus far more open and less dependent on Westminster than would have been the case if newspapers had been mere party organs.' 5 A noted feature of Barker's book is her emphasis on the 1780s as the key period, an observation that is supported by a somewhat exasperated Charles Dibdin who, towards the end of that decade, recalled a simpler time:

I have to speak of newspapers; and the first thing I shall say is, that it is astonishing to see how they multiply. I remember when The Daily Advertiser, The Public Advertiser, The Gazetteer, The Ledger, and two evening papers, made up-except The Craftsman on a Saturday - the whole stock of public prints in LONDON, and one, or at most two papers in a county, contented the people in the country; and really, at that time, there was something like independent principles in the conduct of the public prints. ${ }^{6}$

Newspaper and theatre historians would both agree that the growth of newspapers was facilitated by an increasing public interest in the theatres, theatrical performances, and the lives of actors and actresses. Dibdin, best known as a patriotic English songwriter, was also a keen observer of newspapers and theatres and sorely felt the loss of the press's 'independent principles'. This chapter will adumbrate these observations through a consideration of his first foray into the world of periodical publication, The Devil (1786-7). While it is hoped that this will offer another perspective on Dibdin's contribution to metropolitan cultural activity, the essay will complement Barker's argument by showing that Dibdin's antagonism towards newspapers and theatres was largely motivated by a patriotic belief that their capitulation to commercial forces amounted to a betrayal of their publicsphere responsibilities. So while Werkmeister may have overstated the extent of

${ }^{4}$ Lucyle Werkmeister, The London Daily Press 1772-1792 (Lincoln: University of Nebraska Press, 1963), 1-18.

5 Barker, Newspapers, $4 . \quad{ }^{6}$ Musical Tour, 428. 
political influence on newspapers, it is also fair to say that Barker has not fully accounted for the particular influence of theatres on London's press. Despite the ostensible differences and public spats between newspapers, the thrust of Dibdin's critique is that the industry is a cosy commercial oligarchy in which proprietors and editors profit through the betrayal of the ideals in which the liberty of the press is grounded. Likewise, theatres have similarly reneged on their duty to offer exemplars of moral behaviour in a decorous fashion by being seduced by spectacle, sensationalism, and foreign influences.

\section{THE DEVIL}

Looking back on the publication of The Devil in his Professional Life, Dibdin reflects with a typical mélange of ruefulness and bitterness:

Exasperated to the uttermost, I published, perhaps imprudently, a hebdomadal work, called The Devil. It had, for a time, a most astonishing sale; four thousand of the first number were sold in one day. It was impossible, however, to carry on a plan of this work without managing it by a confederacy; and this confederacy, as might naturally be expected, betrayed me; they connived at a counter publication, played a hundred unhandsome tricks, and, I grew tired and relinquished mine; not, however, till oneand-twenty numbers had made their appearance. ${ }^{7}$

Dibdin's exasperation in 1786 emanated from a number of sources. His partnership with Colonel West and others that built the Royal Circus and Philharmonic Academy on the Surrey shore of the Thames had collapsed and the legal action he took to secure his share of the assets was unsuccessful in 1784. A second project to build a theatre near St Pancras also failed to get off the ground, but not before he lost $£ 290$. Dibdin also claimed that Richard Daly, who managed Dublin’s Smock Alley theatre, reneged on a deal for musical works and only paid about a quarter of what was agreed. In the wake of these disappointments, Dibdin retreated to a village near Southampton, where he wrote his novel The Younger Brother, subsequently rejected by a London publisher (but later published in 1793). The cumulative toll these setbacks must have taken on him goes some way to explaining the rather splenetic tone of The Devil.

Dibdin's weekly periodical was first published on 2 October 1786 by Samuel William Fores. ${ }^{8}$ Priced at two pence, it was 'A Review and Investigation of all Public Subjects Whatever' which included 'Literature, Arts, Arms, Commerce, Men, Measures, the Court, the Cabinet, the Senate, the Bar, the Pulpit, and the Stage'. ${ }^{9}$ The conceit of the periodical is that the Editor is on the point of suicide due to the recent death of his wife when the Devil intervenes to dissuade him. The

\footnotetext{
7 Life, 2:189. Dibdin's recollection is mistaken; there were in fact twenty-two issues of The Devil.

8 Fores (1761?-1838) operated out of Piccadilly and is best known for the sale of satirical prints that largely supported the Pitt side during the French Revolutionary period.

9 Title page of The Devil (2 October 1786).
} 
Devil delivers a vitriolic diatribe against the manners of the age that works its way through the corruption of the nobility and judiciary, and the degeneration of the theatres and newspapers. Inspired, the Editor resolves to begin a weekly paper that will be written 'in the manner of the Spectator' at which point the Devil interjects again testily:

'The Spectator!' exclaimed he- if you could have the assistance of Addison and all his friends, with the united abilities of all the ancients and all the moderns, you would not sell an hundred in a year. I have furnished you with some hints, which are but as a grain of wheat in a field, compared to the number you shall receive from me, if you prosecute your design upon any feasible principle.—But the Spectator in this age!- - no; if you would sell your work otherwise than by weight, take care to have enough in it of the Devil.' (1:10)

Allusions to Addison and Steele's seminal work crop up repeatedly in Dibdin's The Devil. Like the Spectator, the title page states that the periodical is the production of a 'Society of LITERARY GENTLEMEN' and Dibdin draws on a number of literary personae for many of the articles, but there is no evidence that anyone other than Dibdin was the author. ${ }^{10}$ The Devil also claims to eschew party politics, attacking politicians and newspapers aligned to both political parties. Dibdin is fond of printing correspondence in the pages of his periodical, much of which appears to be genuine, although some of which must also be read through the playful lens of the Spectator no.542, which gleefully celebrates the capacity of correspondence to disguise the authorial voice. The second issue of The Devil deliberately echoes that of the Spectator when it begins: 'It was my first intention to have given in this Second Number, a particular description of the different characters which compose our Society' (1:19). Yet, as the Devil's spluttering interjection above suggests, these references serve mostly to point out that the promise and ambition of the public sphere imagined by the Spectator has failed to be realized and London's public institutions are feeble and corrupt shadows of how they were imagined nearly a century earlier. The suggestion is that a disinterested publication with a view to the public good is no longer possible: to succeed in lateeighteenth-century London, one must be driven by spleen or profit (and the former often leads to the latter). And it is clear from the opening issue that the central targets of The Devil will be the newspapers and the theatres. Newspapers have abandoned their claims to be vehicles of rational-critical discourse and now appeal to party sensationalism:

'Reason!' interrupted the Devil,_- the term, and the use of it, is exploded. No, no, you have nothing for it, if you must write, but flattery or abuse. Read the two favourite newspapers; - in one you shall see the legislature, and the members who compose it,

10 The ODNB entry for John Williams, better known as Anthony Pasquin, claims that he was the author of The Devil. However, I have found no evidence to support this. Dibdin himself does not refer to any other contributors. Moreover, Dibdin had come under attack by Pasquin in his popular satire on London's acting community The Children of Thespis (London, 1786). Given that Pasquin attacks Dibdin rather vituperatively in this work, it seems improbable that they would have collaborated. 
treated with the vilest and lowest scurrility, as if ministers and their fate hung at the mercy of every ragged author employed to fabricate the lie of the day;... In one, the Ministry is all vice - in the other, all virtue;- - a circumstance that never did, nor never will distinguish any ministry in the universe.

'The other prints sell in proportion as they lean to party; for there is no medium in this country. All men are rascals, or angels, as they are spoken of by their opponents or adherents.' (1:8)

Concomitantly, the Devil argues that the degraded state of the British theatre is ignored due to the vested financial interests of the newspapers and the theatres, each dependent on the other for sales in a corrupt symbiotic partnership:

On the subject of theatre, indeed, [newspapers] are all agreed; actors, authors, and musicians - though the first imitate, the second steal, and the third compile—are with them arrived to the highest pitch of perfection, when 'tis notorious the theatres have gradually declined for these last fifteen years .... But the inducement is evident; and while free admission, and now and then the reception of a farce, can insure the newspapers, trash must go down; and the new school, as it is called, impotent as it is, be palmed on the rising generation, as an improvement of the old one; though, Heaven knows! a spider's web may with as much propriety be instanced as an improvement on the labours of a silk worm. (1:8-9)

Over the two volumes and twenty-two issues of The Devil published between 2 October 1786 and 22 February 1787, Dibdin remains focused on these two forums of London culture and political life in the pages of what is best described as a satirical miscellany, the mode with which he is so closely associated.

In the opening issue, the Editor cites the Morning Post and the Morning Herald as particularly egregious examples of the sort of partisan editorial lines being taken by the London newspapers as a whole. ${ }^{11}$ He refers to them as Jalap (Herald) and Ipecahuanha (Post), respectively a natural cathartic and emetic, an image that anticipates Gillray's 'Cornucopia of Ignorance' and one in keeping with the scatological tendencies of contemporary political caricature. ${ }^{12}$ Although the public image they maintain is of rank hostility, in fact the papers rely on each other for commercial sustenance. The Editor is determined to demonstrate in what manner they agree amicably in private, to affront one another in the face of the world' $(1: 11)$. They sacrifice-quite cynically — their responsibility to provide disinterested coverage of public affairs for sensationalism in the pursuit of profit. And although he aims his fire at the Herald and Post initially, the Editor makes clear in the next issue that all newspapers are implicated when he describes, with some Miltonic resonance, a 'Convention of Editors'.

\footnotetext{
11 The Morning Herald was founded in 1780 by Henry Bate Dudley, who had Whiggish tendencies. The Morning Post had been around since 1772 and took the Ministerial line.

12 See Vic Gatrell, City of Laughter: Sex and Satire in Eighteenth-Century London (London: Atlantic, 2006), 179-209.
} 
On Monday evening last all the Editors of the morning papers attended, as usual, at the theatre upon duty. The sound presently echo'd from box to box-'Have you seen the Devil?-what a damn'd fellow it is- he has cut us to pieces.' At last they grew so vociferous, that fearing to disturb that part of the audience who pay their money, and also that they should expose themselves ... they agreed to put on manly resolution, and meet at Jupp's together. (1:26)

After these digs at the newspapers for their slavish concern for money, cabal-like secrecy, and even for their seating (identifying them as sitting in the boxes rather than the pit suggests they have abandoned the intellectual classes for social standing), the Editor describes their meeting: '[B] ustling Billy' (possibly William Jackson, until recently editor of the Morning Post) opens a discussion which features comments and suggestions ranging from outright hostility to apathy by Henry Sampson Woodfall (Public Advertiser), Henry Bate (Morning Herald), 'Mr. Gazetteer' (James Perry), 'Mr Ledger' (possibly Leonard MacNally), and an unidentified Irishman (possibly Dennis O’Bryen, Leonard MacNally, or William Sampson). The following issue sees the group publish 'Resolutions of the Scrambling Newspaper Party', which sets out a strategy of ignoring The Devil in their publications while funding campaigns to identify the Editor and using 'three-penny halfpenny men' to discredit him in coffeehouses (1:42). The Editor revels in his success and continues to lambast them for scandalmongering, partisanship, sensationalism, inaccurate reporting, and plagiarism, the chief charges that run through the issues of The Devil. His is a noble task: 'to interrupt their unworthy career is all I expect - to distinguish the liberty from the licentiousness of the press - to separate the gold from the dross - to shew the difference betwixt firmness and abuse- betwixt satire and scurrility — and I shall find them, let them try to evade me how they will' $(1: 45)$.

\section{THE DEVIL IN PUBLIC DEBATE}

At this point, we should note that Dibdin can be aligned with a broad critique of newspapers that took place in the 1780s, the second of two decades of what Werkmeister termed the 'age of the scandal sheet'. ${ }^{13}$ As Barker has documented, there were a number of portentously monikered newspaper correspondents in the 1780 s, such as 'Alfred' and 'Frankly', who lamented the licentiousness of the British press—so Dibdin is in no way as maverick as he portrays himself to be. ${ }^{14}$ The proliferation of new press titles during the decade provoked much jostling and, consequentially, a deeper level of scrutiny of their motives and editorial positions, a fact acknowledged by the newspapers themselves. The General Advertiser and Morning Intelligencer printed an 'Estimate of the Merits and Demerits of the Newspapers printed in London' where it marked nineteen different newspapers out of twenty in a host of categories that included Intelligence, Truth, Independence,

13 Werkmeister, Daily Press, $4 . \quad 14$ Barker, Newspapers, 12-13. 
Servility, Wit, Slander, Insidiousness, and Absurdity. ${ }^{15}$ Newspapers also featured in political caricatures of the period, highlighting their capacity to inflame and participate in political discourse. ${ }^{16}$ Hence Dibdin is one of an array of commentators from the period engaged in holding the expanding newspaper industry to account by scrutinizing its activities and motives with forensic attention.

The distinctive value of Dibdin's contribution to these debates is that The Devil offers detailed material on the characters of the men who ran the press in the 1780s: the descriptions of their exchanges give us a sense of their personalities and how they interacted with each other, or at least the public perception of same. 'The Rev. Mr. Herald' (Henry Bate Dudley), for instance, emerges in Dibdin's pages as the dominant personality of the newspapermen (1:29). Moreover, Dibdin is very careful to support his journalistic critique with data, often at considerable length. Often his criticisms, particularly to do with plagiarism and inaccuracy, are supported by the documentation of particular cases on a paragraph-by-paragraph level. Those criticisms with regard to the alleged positive reception of a play by a London audience are contrasted to his own, more desultory, experience of attending the play. ${ }^{17}$

In the 1780s increasing coverage of theatrical events facilitated the growth of the newspaper industry. However, argues The Devil, this was to the detriment of both industries:

For the stage also you must be an adept in puffing; for if you cannot demonstrate that languor is delicacy-rant, fire-stalking, grace—coldness, judgment-noise, feeling - affectation, ease—grimace, wit-buffoonery, humour-or, distortion the vis comica, you know not theatrically how to praise the acting of the day. If you cannot prove, that bombast is the true sublime-ribaldry, genuine comedy-plagiary, originality-or, a pun, the ne plus ultra of wit, you must not attempt to speak of performances. And, if you have not the knack adroitly to represent, that a thin audience is an overflowing one-that silence, dissatisfaction, disgust, contempt, nods, shrugs, and shakes of the head, are bursts of applause-roars of laughter, universal approbation! transport! delight!- - for, I believe, the theatres have now gone through every expression of satisfaction in the language but extacy $[s i c]$ and raptureyou are not fit to describe the reception every performance is sure to meet with in the dramatic advertisements on the day following its first representation; though threefourths of the audience had, the evening before, gone away perfectly of [sic] opinion that it had been completely damn'd. (1:7)

Again, there is a long tradition of writers lamenting the degeneration of the theatres, particularly on the grounds of spectacle, from Thomas Rymer through Addison

15 General Advertiser and Morning Intelligencer (9 January 1782).

16 See, for example, 'The Whig Club, or the State of the Blue and Buff Council' (1784), 'The Political Sampson in Revenge Sets Fire to the Country' (1784), and 'A Barber[']s Shop' (1785) in Mary Dorothy George, Catalogue of Political and Personal Satires, 11 vols (London: Trustees of the British Museum, 1938), 6:150, 178, 269.

17 See, inter alia, the review of Leonard MacNally's Richard Coeur de Lion in the fourth issue (1:54-64). The Editor works his way through a number of reviews from the newspapers, before offering his own detailed critique over the course of no fewer than ten pages. 
and Goldsmith to Sheridan. ${ }^{18}$ What Dibdin does distinctively and successfully is to expose the corrupt commercial symbiosis of newspapers and dramas. By scrutinizing dramatic performances that he has attended and then highlighting the discrepancies between his experience and those reports from the critics, he gives unparalleled and uncomfortable clarity to the overlap between the two spheres of influence. ${ }^{19}$ The Editor supplements his exposure of the unhealthy relationship between newspapers and theatres by turning his attention to the greed and venality of theatre managers: 'Timoty $[$ sic $]$ Toby Tickle' proposes a 'Plan for constructing Dramatic Pieces upon Mechanical Principles' which will get 'rid of the expence, trouble, and impertinence of poets and musicians, amounting to a considerable annual saving of mortification and money' (1:86). Again, this draws on the Spectator, whose Essay 31 poked fun at a dramatic 'projector' who aspired to solve the supposed conundrum of having to travel around London to sample different types of theatrical entertainments: 'In order to remedy this great Inconvenience, our Projector drew out of his Pocket the Scheme of an Opera, Entitled, The Expedition of Alexander the Great, in which he had disposed all the remarkable Shows about Town, among the Scenes and Decorations of his Piece. ${ }^{20}$ The Devil offers a more acerbic take on dramatic miscegenation: it also pokes fun at the strange mélanges offered on London stages and, like the Spectator, is distraught at the dominance of Italian opera in London. ${ }^{21}$ Moreover, the satire further documents a number of systemic 'back-of-house' changes which have taken place in London theatres to its detriment: the managers taking a bigger slice of revenues, author benefit nights being offered under worse conditions, a decreasing pool of acting talent, and worsening employment conditions for actors. All of this occurs while the population of London and its theatre audiences have increased significantly: the suggestion is that managers have been wringing their hands publicly while siphoning off profits for themselves, uncaring as to the quality of the dramatic fare they are serving up, and having little concern for their employees. Tickle offers mock sympathy to the managers and suggests getting rid of authors altogether:

But if you discard authors, how are you to get performances? to which I answer,- - that with much labour and pains upon the very principle, that your pieces have been knit and spun for several years back, have I constructed a kind of dramatic loom, from which you shall get performances of all dimensions, materials and qualities;-I'll weave tragedies for you, with situations that have escaped the discernment of that satiric lynx, Mr. Sheridan:- as to comedies, you may pick and chuse; - - 'll manufacture farces that

18 See David O'Shaughnessy, William Godwin and the Theatre (London: Pickering \& Chatto, 2010), 87-9.

19 The plays which come up for particular examination include: MacNally, Richard Coeur de Lion (CG, October 1786); John Burgoyne, Richard Coeur de Lion (DL, 24 October 1786); Frederick Pilon, He Would Be a Soldier (CG, 18 November 1786); Hannah Cowley, The School for Greybeards (DL, 25 November 1786); Thomas Arne's popular opera Artaxerxes (CG, 13 January 1787); and Elizabeth Inchbald, Such Things Are (CG, 10 February 1787).

20 Spectator 31 in Erin Mackie (ed.), The Commerce of Everyday Life: Selections from The Tatler and The Spectator (Boston: Bedford, 1998), 352.

21 Compare Spectator 18 to The Devil, 1:106-8. 
you may sketch to operas, and operas that you may shrink to farces.-But a good home-spun spectacle is your object, the materials from abroad; there you may excite curiosity, and defy criticism; for who are ill-natured enough to abuse the peacock's legs while they look at his feathers? (1:89-90)

The Editor draws attention to the commodification of theatrical entertainment and the critical timidity of current commentators. Tickle's suggestion even echoes Swift's Modest Proposal at the close, telling managers that they may 'chop, change, adopt, dispose, extend, compress, snip, hack, hew, strain, distort, mangle, manacle, fritter, or dissect [his proposal] how, and in what manner you please' (1:91).

The allusion to $A$ Modest Proposal and its withering attack on colonial exploitation fits into a pattern. Literary echoes play an important part in The Devil, with Dibdin clearly drawing on particular authors readers would associate with enlightened critiques of unchecked commercial rapacity, critiques that were consistent with his unease with the commercial intimacy between newspapers and theatres. Over the course of four issues, Dibdin publishes a parody of Goldsmith's The Deserted Village (1770), titled 'Innovation', with a hilarious mock dedication to John Burgoyne, previously a British general in the American War of Independence, who had not covered himself in glory. ${ }^{22}$ Goldsmith's poem was one of the best known and most powerful attacks on Whiggish ideas of commercially-enabled improvement, luxury, and exploitation of the lower orders, making it ideally suited to Dibdin's critique of both internal and external theatrical matters:

Joy-giving playhouse! best delight in town

Thy merit's fled, and any stuff goes down.

'Midst thy bays the pruning knife is seen,

And critic fury tears away the green;

Monopoly now grasps the whole domain,

And Authors, Actors starve, nor dare complain.

Swift is also echoed more directly over a series of eight issues in Volume Two. 'The World in a Nutshell: or Circumnavigation's Non Ultra' documents the 'Voyages and Adventures of SIMON SINGREEN' beginning with his trip to the 'Antipodes of England,- - being an Island in the South Seas' (2:28-9). Shipwrecked on this island, Simon's experiences reveal the deficiencies of British life right from the off when he is revived by a cup of smuggled tea, a dig at the perceived failure of William Pitt's attempts to curb such activity. ${ }^{23}$ Singreen continues jubilantly to celebrate the superiority of England to its Antipodean reflection by documenting the corruption of its politicians, its bloated legal world, the artifice and vacuity of its women, the prostitution and crime in its capital, the credulity of its people, the

\footnotetext{
22 'Sir, I can have no expectations in an address of this kind, either to add to your reputation, or establish my own; you can gain nothing from my admiration, as I am ignorant of that art in which you are said to excel* ...' The deadpan footnote reads '*losing an army'. The dedication is signed 'I am, Sir, with great admiration of your firmness in the time of captivity, be it or your person, or your reason, Your most obedient.' 'Innovation' is published in 1:9, 11, and 13, and 2:2.

23 Pitt's ODNB entry claims, however, that his anti-smuggling measures were largely successful.
} 
corruption of its press, theatre, and parliament (which the 'ups' and the 'downs' contest). Finally, we should note the inclusion of a play, presumably authored by Dibdin, but which the Editor cheekily suggests may be a translation from Voltaire (1:149). French Faith; or, the Virtuous Individual is an attack on the commercial treaty that Pitt had drawn up with France. The play's depiction of the bloody events of St Bartholomew's Day 1572 is meant as a warning against the double-dealing French and a reminder of intense religious and cultural differences. ${ }^{24}$ Commerce is imagined here as misguidedly aligning two implacably unsuited opposed parties, and Pitt's commercial treaty comes under sustained attack in the pages of The Devil.

Yet for all the Editor's pretensions of being motivated by disinterested patriotic intentions, it is evident that Dibdin is also moved by personal vindictiveness. A difficult character, he had plentiful cause to direct his vitriol against newspapers (which had ignored his contribution to the Stratford Jubilee, for one thing) and the theatres. To offer one specific example, he used the weekly publication to attack Richard Daly, the Dublin theatre manager with whom he had fallen out. The Editor publishes a letter from 'Little Ireland', who warns of the perfidious Daly and gives a blow-by-blow account of the falling out with Dibdin which is, rather unsurprisingly, entirely sympathetic to Dibdin. The Editor adds a note to the end of the letter disingenuously declaring that if Dibdin wants to respond, he will include the letter-if he receives it early enough $(2: 103-5)$. The letter follows in due course, and this device allows Dibdin to paint himself in a glowing and noble light under his own name after maligning Daly's character through the 'Little Ireland' soubriquet $(2: 136-40)$.

\section{THE DEVIL IN CONTEXT}

A tremendous amount of creative energy was expended on the twenty-two issues of The Devil, but how might we assess its impact on the London public and its institutions? The difficulty is that much of the evidence that we have is internal. In other words, we are largely reliant on the periodical itself and Dibdin's reflections on it to answer this question. In The Professional Life, Dibdin claims that the periodical sold 4,000 copies of its first issue in one day, but there is no way to verify this figure. Barker offers a selection of sales figures for daily newspapers of 3-5,000 at this time, but warns that these figures should be treated with caution as it is in the newspapers' respective interests to exaggerate sales figures to advertisers. ${ }^{25} \mathrm{We}$ should also note that the price of The Devil increases from two pence, to two and a half, to three pence over the course of its life, which may indicate that falling

24 The supposed play also features in a contemporary caricature The Treaty of Commerce or New Coalition (Samuel W. Fores, 26 February 1787), which shows a duplicitous Louis XVI with the play partially hidden under his foot while negotiating with George III. Fores, of course, also published The Devil.

25 Barker, Newspapers, 23. Readership would have greatly exceeded sales, although it is very difficult to be precise as to what the appropriate multiplier should be as estimates varied wildly. See Jeremy Black, The English Press in the Eighteenth Century (Beckenham: Croom Helm, 1987), 105. 
demand required the price to rise to cover increased unit production costs. On the other hand, the Editor claims that the first price increase (which coincided with the third issue) was driven by 'encouragement' from 'a large and respectable body of subscribers' (1:43). We can add that when the tenth issue was published, an advertisement stated 'Number I and Number III being now wanted to make up regular Sets, Notice is given, that a new Impression of them will be ready the Beginning of this Week', further suggesting buoyant sales. ${ }^{26}$ The Freemason's tavern hosted a 'Gentleman' presenting an 'Attic Entertainment of Readings and Imitations' which included extracts from Shakespeare, Sterne, and The Devil. As tickets were on sale for 2s. $6 \mathrm{~d}$., this suggests that Dibdin's periodical had achieved a certain status among his target audience of gentlemen. ${ }^{27}$ After The Devil published a less than complimentary review of Hannah Cowley's The School for Greybeards (4 December 1786), the General Advertiser (5 December 1786) immediately leapt to her defence against this 'unmanly attack'. ${ }^{28}$ Nevertheless, the same newspaper for 8 December 1786 announced a series of changes had been made to the play, suggesting that The Devil's opinion had weight. Additional evidence that Dibdin had made something of a public splash is contained in the third issue, where the Editor revels in his anonymity in the wake of much public effort being spent on trying to uncover his identity:

[T] he pleasantest consequence of these various surmises is, that it has been attributed to twenty different authors, not one of whom has the slightest qualification for so bold an attempt. Among these are, three lords, a duke, two bishops, and a judge. Some have said the Jesuitical Edmund begins to waver, and tempted by the Devil, keeps himself in equipoise, like a stationary balloon, to catch an Eastern gale. We have a long letter, to prove it is written by some 'Devil of a Dennis'; but I would have its author to know, 'We speak to no scavengers.' Mr. Tickel is also said to have a hand in it; for who but the author of Anticipation could write the Dreamer?... Nor is there a word of truth in the report industriously circulated, that Mr. Sheridan, by way of giving the Duenna a lift on its revival, wrote our critique on that piece. (1:39)

The balance of evidence-circumstantial as it may be-does suggest that The Devil made an impact on the public consciousness of the mid-1780s. It was certainly in tune with contemporary criticisms regarding the licentiousness of the press. What the periodical offers scholars today is a colourful take on the interactions of significant journalistic figures from the period. It also gives granular detail on the commercial interdependence of the newspapers and theatres, a facet of newspaper economics for which scholars have not sufficiently accounted. But it also gives a wonderfully vivid example of Dibdin's literary range, and we might conclude by

26 St James's Chronicle (7 December 1786).

27 The 'Gentleman' in question may be the literary editor George Stevens (1736-1800). The advertisement in the Morning Herald (7 November 1786) states that the performer assisted Samuel Johnson with his edition of Shakespeare.

28 In a blow for female equality the Editor had asked, 'As to this comedy then, I ask any man of reason and understanding, whether there ever appeared on any theatre, a more indecent abortion, and if that should be allowed, whether its being written by a lady, is not the very reason why it ought to be considered as an object of public reprehension' (1:160). See also 1:174-5, 192. 
asking why Dibdin devoted so much energy to the satirical miscellany at this point in his career. Certainly, there would have been generic appeal to him: a satirical miscellany which allowed him to adopt a variety of different voices and present ideological positions in a humorous and knowing fashion would certainly have suited a theatrical temperament that would go on to manage the Sans Souci. What the periodical also offered Dibdin was a chance to settle scores while also delineating a sober critique of the part that commerce and its subordinates, greed and selfinterest, had played in the corruption of the ideals of the Spectator.

In Essay 69 of Addison and Steele's journal, Mr Spectator describes the Royal Exchange as a forum for cosmopolitan and enlightened exchange, a space where the world comes together for mutual gain and advantage. 'It gives me a secret Satisfaction', he writes, 'to see so rich an Assembly of Country-men and Foreigners consulting together upon the private Business of Mankind, and making this Metropolis a kind of Emporium for the whole Earth'. ${ }^{29}$ Such activity, its whirl of movement and progress, is celebrated by a publication which sees itself as a vehicle for societal improvement: 'Among those Advantages which the Publick may reap from this Paper, it is not the least, that it draws Men[']s Minds off from the Bitterness of Party, and furnishes them with Subjects of Discourses that may be treated without Warmth and Passion.'30 The Spectator, a wartime publication, posited a post-conflict new global economy, lubricated by enlightened trade. But by the 1780s, Britain had been involved in a number of further significant conflicts and the ambition of the Spectator was proved groundless, in Dibdin's view. Trade and commerce were at the top of the political agenda in relation to America, France, Ireland, and India during the disputatious 1770s and 1780s. Commercial treaties and agreements were the stuff of discord and enmity, hence the day of the disinterested spectator would never dawn, not least while individuals sought to exploit and augment public-sphere dissonance for the gain of profit. The Devil, then, might be thought of as an impassioned verdict that the aspirations of a Whiggish commercial Enlightenment had definitively failed. Dibdin's attacks on individuals such as Daly might well have been personal, but these were subsumed to his broader concern for the degeneration of the public sphere and the crass symbiosis of what should have been two proud bastions of British liberty, the theatre and newspapers. Dibdin's later periodical, The By-stander; or, Universal Weekly Expositor (August 1789 to February 1790) further supports this claim.

\section{CODA: THE BY-STANDER}

Dibdin ceased publication of The Devil in February 1787. It is uncertain what caused him to stop, although the penultimate issue mutters darkly about 'many attempts to injure [The Devil]' (2:292). His Life suggests, as we have seen, that there was a 'confederacy' aligned against him which brought out a rival publication

29 Mackie, Commerce of Everyday Life, $203 . \quad 30$ Ibid., 99. 
and were not averse to playing dirty in order to quash The Devil. Eventually, Dibdin writes, he simply grew tired. This is certainly plausible, as there were any number of people who might have had it in for this periodical, not least the proprietors of The World, Edward Topham and John Bell. The World first appeared to the London public in January 1787 at the same time as the second volume of The Devil. Dibdin seems to have had a particular dislike for this paper, which received a farrago of abuse such as 'The Poor World struggles hard,- -its nonsensical incoherence is like the delirium of a man in an incurable fever, whose ravings are more violent and less collected in proportion, as the moment of his dissolution' (2:66). It is at least possible that Topham and Bell might have taken steps in response. Yet there is a more prosaic explanation: he simply decided to abandon the publication as he was embarking on a countrywide tour in March 1787 in anticipation of emigrating to India.

Dibdin, as we know, never went to India, and he ended up back in London. The ODNB notes that 1789 was the year that he composed many of his most popular and patriotic songs, such as 'Tom Bowling' and 'Poor Jack'. It was also the year that he returned to periodical publication with The By-stander. The withdrawalpartially at least- suggested by the title is notable, and a more direct evocation of the aspirations of the Spectator. Certainly, there had been a moderation of tone and content: for instance, there is much space given over to historical surveys of French and Italian theatre (and less jingoistic vitriol) and there is dedicated space given to 'The Essayist', a literary persona who writes on topics of abstract general interest such as 'desire, hope, and possession' (325), 'the art of pleasing' (393), and 'composition in writing' (358). It would be untrue to say, however, that there was a complete rupture with The Devil—Dibdin refers disparagingly again to the commercial treaty of the 1780s (141) and pointedly lauds the Drapier's Letters in a paean to Swift (161), for example. He offers an excoriating broadside against The World, a paper he truly seems to dislike, of which this is only a snippet: 'Indeed a low paper it ever was. Is not every thing that is worthless, senseless, pitiful, incongruous, indecent-low? Is not every thing that imposes on mankind, that affronts our understanding — low? Are not arrogance, foppery, and folly low?' (317). Yet the reader of The Devil and The By-stander will find that Dibdin's tone has mellowed in the latter publication in sympathy with the more passive title. Dibdin was writing in the midst of the French Revolution, and a desire to tone down the more antagonistic aspect of his writing would be in keeping with a growing moderation in many Britons. Doubtless, as David Kennerley shows in Chapter Five of this volume, in The By-Stander Dibdin continued to keep both barrels trained on Britain's institutional failings; however, this later periodical is also careful not only to cut down but also to shore up existing institutions and to set them against the iniquity of French alternatives, a trope pervasive in the decade. In the first issue of The By-stander, he draws attention to France where the 'worst anarchy and the most barbarous cruelty has so recently reigned' (9) before closing with an ode 'written to commemorate the Birth-Day of his Royal Highness the Prince of Wales' of almost 300 lines (14-16). The major difference between the two periodicals is one of tone; Dibdin, perhaps recognizing a need for restraint, 
reins himself in at a time of national crisis. His critiques of commerce, self-interest, and venality remain, but with the nation under threat, he offers some balance. The emergence of a more moderate tone in tandem with the writing of his more patriotic and successful songs seems consistent, although a hint of the Devil would always remain in Dibdin.

\section{ACKNOWLEDGEMENT}

I wish to acknowledge the generosity of the European Commission's Marie Curie programme, which facilitated the research and writing of this chapter. 


\title{
5
}

\section{Loyalism, Celebrity, and the Politics of Personality}

Dibdin in the 1790 s

\author{
David Kennerley
}

On 12 May 1792 William Locke, the printer and publisher of The Observer, found himself before the Court of King's Bench on a charge of publishing a 'libellous paragraph reflecting upon the character of Mr. Charles Dibdin'. ${ }^{1}$ The paragraph in question implied that the playwright Isaac Bickerstaff was the real author of the songs Dibdin was currently performing to great acclaim at the Sans Souci theatre and, in a series of innuendos, insinuated that their relationship may have consisted of more than just plagiarism:

The reports circulated of Mr. BiCKERSTAFF's death, we are extremely happy to contradict; the more so, as it might probably deprive the public of Mr. DiBDis's exertions to amuse them. Men of fine feelings, are not apt to forget their dearest friends.

Poor DibDin, with all his genius and talents, cannot succeed, although, it is said, he is backed by some persons of fame and Notoriety.

BICKERSTAFF is lately arrived from Italy-he was last night behind the scenes at his old friend DibDin's Sans Souci. ${ }^{2}$

These allusions stemmed from the fact that Bickerstaff and Dibdin had formerly been close associates in a highly successful theatrical partnership, producing operas such as The Padlock in 1768. However, their joint endeavours had come to an abrupt end in 1772 when Bickerstaff fled the country following accusations of sodomy. ${ }^{3}$

Locke's trial eventually concluded in a conviction in February 1793, but, knowing that Locke was only the publisher and not the author of the paragraph, Dibdin struck a deal to mitigate the sentence Locke would receive on condition he would stand as a witness against the author, Isaac Swan, in a subsequent prosecution. ${ }^{4}$ Swan, a lawyer and hack writer for The Observer and The World newspapers, had continued during Locke's trial to taunt Dibdin through a series of paragraphs repeating and embellishing upon the same themes—revenge, perhaps, for Dibdin's

1 The Diary; or Woodfall's Register (14 May 1792).

3 Tasch, The Dramatic Cobbler, Chapter Twelve.
2 The Observer (18 March 1792).

4 Life, 3:222-4. 
own journalistic assault on The World a few years earlier, as detailed in Chapter Four of this volume. ${ }^{5}$ Having secured Locke's promised testimony, Dibdin launched a second, and this time civil, suit against Swan in the Court of Common Pleas on 18 May 1793, which terminated in victory and an award of $£ 200$ damages. ${ }^{6}$ In a subsequent, more embarrassing episode, he again went after Swan and the printer of The World, Robert Bostock, for another paragraph, still asserting plagiarism from Bickerstaff, but also describing Dibdin's Sans Souci shows as badly performed, poorly attended, and only applauded by paid claqueurs. This suit, heard at the Court of King's Bench on 25 June 1793, was found in Dibdin's favour, but with the humiliating award of only one shilling in damages, effectively a victory for the defendants. ${ }^{7}$

Why did Dibdin respond to these press attacks by launching libel trials, especially given the expense of such proceedings, rather than simply ignoring them? What was he trying to prove or to defend? The answers to these questions lie in the form of solo performance that Dibdin had pursued since 1787, which depended for its success on the cultivation of a carefully controlled sense of intimacy with the persona of the performer. As we shall see, key traits in Dibdin's public image were his supposed naturalness, sincerity, independence, and manliness. The intended effect of this persona was to underwrite the veracity and honesty of the opinions and sentiments contained in the songs and anecdotes he performed at the Sans Souci, casting Dibdin as a plain speaking, open, independent voice on current affairs that his audience could trust. Given the rising political temperatures of 1792-3, this performance of personality had a pressing significance, one that complicates the received picture of Dibdin as the tub-thumping loyalist songwriter par excellence. Certainly his songs espoused loyalist values, sometimes very overtly and forcefully, but he was also keen to point out the vices of contemporary authority figures, targeting ministers, aristocrats, and bishops as hopelessly corrupt, hypocritical, and failing in their duties. His was therefore an independent loyalism', ready to affirm the merits of the British constitution and especially the virtues of the ordinary soldier and sailor striving to defend it, while also eager to counter any suggestion that expressing such values was simply a servile pandering to the dictates of a corrupt and incompetent Establishment. Appreciating this exposes numerous resonances between Dibdin's political language and that of contemporary radicals and reformers, since their calls for constitutional reform were frequently based on similar claims that they spoke from a position of true independence and could thus offer a sincere and honest assessment of the political reality to the British public. These libel trials were consequently far from an insignificant spat. Exploring Dibdin's response to them offers important insights into the influence of celebrity upon late-eighteenth-century performance culture and allows us to uncover more fully the diverse and multivalent strands of loyalism in this most turbulent era of British politics.

\footnotetext{
5 The World, issues for 13, 15, 20, 22, and 25 October 1792.

7 Diary (26 June 1793); Morning Chronicle (26 June 1793).
} 


\section{THE PERFORMANCE OF PERSONALITY}

In recent years, the eighteenth century has increasingly been seen as witnessing the birth of modern 'celebrity', distinguished from earlier types of fame through its non-dependence on birth or rank, its use of the new media made available by the emergence of the public sphere, such as newspapers, magazines, and cheap visual prints, and its emphasis upon a sense of intimacy with the private personality of the public individual. ${ }^{8}$ As several scholars have observed, particularly in relation to Georgian theatrical culture, the obsession with personality and its dissemination through a vast range of media marks out this period from its predecessors. Whether through the explosion of theatrical biographies, the subtle language of the theatrical portrait, or even through the collection of porcelain figurines of actors and actresses, the communication of personality and the desire for intimacy were basic and distinctive elements of Georgian performance culture. ${ }^{9}$

Dibdin's solo shows carried the influence of celebrity upon theatrical performance to new heights. As contemporaries attested, the success of these shows depended upon creating a sense of intimacy between performer and audience. The actor and playwright John O'Keeffe recalled how, at one of Dibdin's performances in 1792, 'he ran on sprightly and with nearly a laughing face, like a friend who enters hastily to impart to you some good news'. ${ }^{10}$ Similarly, George Hogarth, a juvenile attendee of Dibdin's performances, drew a distinction between the friendly, intimate style Dibdin adopted and the more distant feel of a public theatre: 'His manner of speaking was easy and colloquial; and his air was more that of a person entertaining a party of friends in a private drawing-room, than of a performer exhibiting to a public audience.'11 The Gresham Professor of Music, Edward Taylor, who as a youth in Norwich saw Dibdin perform, concurred that his performance 'was related with great ease and effect: no attempt at oratory or declamation, but simply as if he was relating his travels to a party of friends'. ${ }^{12}$ This friendly, informal, intimate style, perfectly suited to the small-scale cosiness of the Sans Souci (as shown in Figure 7.1), seemed to engender a feeling of privileged insight into private space, both physically and psychologically, as Judith Hawley describes in Chapter Six of this volume.

8 Chris Rojek, Celebrity (London: Reaktion, 2001), 13-14, 19, 28-9; Leo Braudy, The Frenzy of Renown: Fame \& its history (Oxford: Oxford University Press, 1986), 361-89; Simon Morgan, 'Celebrity: Academic "Pseudo-Event" or a Useful Concept for Historians?' Cultural and Social History 8/1 (2011): 95-114.

9 Joseph Roach, 'Public Intimacy: The Prior History of "It." ', in Mary Luckhurst and Jane Moody (eds), Theatre and Celebrity in Britain, 1660-2000 (Basingstoke: Palgrave Macmillan, 2005), 15-30; Cheryl Wanko, Roles of Authority: Thespian Biography and Celebrity in Eighteenth-Century Britain (Lubbock: Texas Tech University Press, 2003), 9-16; Laura Engel, Fashioning Celebrity: EighteenthCentury British Actresses and Strategies for Image-making (Columbus: Ohio State University Press, 2011), 14-20; Heather McPherson, 'Theatrical Celebrity and the Commodification of the Actor', in Swindells and Taylor, Handbook of the Georgian Theatre, 192-212.

10 John O'Keeffe, Recollections of the Life of John O'Keefe, written by himself, 2 vols (London, 1826), 2:322.

${ }_{11}$ Hogarth, xx. 12 Taylor, f.8. 
This sense of a privileged glimpse into Dibdin's personality as a unique selling point of the Sans Souci performances is reinforced by numerous comments that the anecdotes, lyrics, and music of these performances reflected and revealed the private feelings of their author. A correspondent of The Oracle observed of Dibdin's serious songs that they 'do his feelings credit', while the London Recorder felt his compositions reflected 'the highest honour on Mr. Dibdin's mind and abilities, as an author and a composer'. ${ }^{13}$ Other critics wrote of Dibdin's songs as doing 'equal honour to the head and heart of their author' or of 'words and music [that] possess mind, character, and taste'. ${ }^{14}$ As Isaac Land observes in Chapter Eleven, such ideas would later develop into the Victorian moralizing gloss given to Dibdin's songs and character by admirers such as Hogarth. A few contemporaries found this emphasis on the personality of a single individual distasteful — the short-lived satirical paper the Tomahawk or Censor General branded Dibdin one of the 'three greatest egotists of the age'-but most members of Dibdin's substantial audiences appear to have been eager to catch the glimpses of his personality interwoven in the fabric of his anecdotes and songs. ${ }^{15}$ In essence, then, Dibdin's performances traded on the carefully controlled disclosure of a public persona, perhaps a form of the 'interiority effect' that Felicity Nussbaum has observed in the performances of contemporary actresses, and the manufacturing of a sense of physical and psychological intimacy at the Sans Souci. ${ }^{16}$

\section{PROJECTING A PERSONA}

Dibdin's now irrecoverable performances were his most direct method of creating the right impression of his personality in his audiences' minds, but clear traces of this process are captured in his autobiographical and other writings and in the responses of contemporary audience members. He places great emphasis, for instance, upon 'nature', 'sincerity', and cognate terms in describing himself and his work. 'In my songs', he writes, 'I have gone for truth, for nature, for simplicity, for strength, for sentiment and for character.' ${ }^{17}$ In writing a ballad, Dibdin observes, 'the mind shuns every thing affected and fantastic, and seeks an asylum in the bosom of nature', while he laments that 'every attempt to establish simplicity and nature has been considered [by the public] as paucity and imbecility'. ${ }^{18}$ As well as emphasizing his own straightforward sincerity, he condemns those unwilling to state their opinions openly and honestly. In his chapter on 'Anonymous Letters' in his Observations on a Tour, Dibdin writes of the 'palpable and malignant deception'

\footnotetext{
13 The Oracle and Public Advertiser (13 October 1794); The London Recorder, and Sunday Gazette (22 March 1795).

14 'Lyceum', The General Magazine and Impartial Review (December 1789): 562; 'Mr. Dibdin's

Wags and Oddities', The General Magazine and Impartial Review (February 1791): 86.

15 The Tomahawk, or Censor General (21 January 1796).

16 Felicity Nussbaum, Rival Queens: Actresses, Performance and the Eighteenth-Century British Theater (Philadelphia: University of Pennsylvania Press, 2010), 20.

17 Life, 1:xxiii. 18 Ibid., 3:41-2.
} 
practised by those who wrote such anonymous criticism. 'Truth loves the light,' he declares, 'it never skulks; it scorns to lurk in whispers and inuendoes [sic]; it is honest and open. It does not insinuate; it proclaims.' ${ }^{19}$ In defending his total rejection of all the 'advice' contained in these letters, Dibdin asserts defiantly that 'nature has permitted me to be exactly what I am and neither more nor less'. ${ }^{20}$ Furthermore, such personal qualities were an explicit subject of his performances; an advertisement for his entertainment for the 1793-4 season, Castles in the Air, declared the anecdotes and songs would discuss topics such as 'Simplicity', 'Truth', and 'Candour'. ${ }^{21}$ Nor need we take Dibdin's word alone: one contemporary journalist commended Dibdin's performances by observing that 'the light and superficial, may applaud the trick of art-but a manly and well-ordered taste, will ever prefer the touch of nature'. ${ }^{22}$ Similarly, Taylor later reflected that the things that most distinguished Dibdin from his many imitators were 'those genuine touches of nature and unaffected feeling which appeared to flow from him without effort'. ${ }^{23}$

Alongside the natural and sincere, Dibdin constantly, almost obsessively, declared his sense of 'independence', which was inextricably tied, as for many men in this era, to his sense of his masculinity. Linda Zionkowski, citing the examples of Savage, Pope, and Johnson, has noted that celebrated authors often found themselves in a predicament regarding their relationship with the public: although largely dependent upon them, to acknowledge this fact threatened the independent masculine identity deemed essential to successful authorship. ${ }^{24}$ Dibdin seems to have adopted a similar position, writing, '[W] hen I speak of the public, I shall certainly not condescend to use any of the fawning, cringing terms that are in general made use of upon these occasions. They are degrading to the man, and insulting to his protectors. ${ }^{25}$ Although he admits 'I get my bread by the public', he nonetheless insists, 'I will not be a servant to any one. I am no minion, no dependant $[$ sic $] .{ }^{26}$

Most notably of all, yet rather duplicitously, Dibdin emphasized his manly independence by rejecting 'puffing'. 'I never wrote nor connived at a single puff in my life,' he declares, though he quickly adds 'if exaggeration be meant by the term puffing.' ${ }^{27}$ Elsewhere, he elaborates on this belief: 'I had always determined to stand or fall by my own fair pretensions. In all that I ever directly, or indirectly, suggested to the public, I demanded fair justice, and sought candid investigation; and, above all other revolting ideas, I disdained the vice of puffing. ${ }^{28}$ As he implies, the puff threatened not only a performer's independence, but also his sincerity and candour with the public. Of course, there is plenty of evidence to suggest that Dibdin cultivated alliances with important press figures, such as William Woodfall,

19 Observations, 2:157. 20 Ibid., 2:158.

21 Morning Post (7 November 1793).

22 [Original emphasis], 'Sans Souci', The General Magazine and Impartial Review (November 1791): 582 .

23 Taylor, f. 2.

24 Linda Zionkowski, 'Celebrity violence in the careers of Savage, Pope and Johnson', in Tom Mole (ed.), Romanticism and Celebrity Culture, 1750-1850 (Cambridge: Cambridge University Press, 2009), 168-85.
25 Life, 2:91.
26 Ibid., 4:9-10.
27 Ibid., 1:6.
28 Ibid., 3:219. 
and that these brought him a string of immensely favourable reviews and plugs for his song publications. ${ }^{29}$ Nevertheless, even if Dibdin was as mired in the swamp of press manipulation as any of his theatrical contemporaries, it remained absolutely vital to him to prove to the public his 'independency of mind', which, as he declares at the close of his Professional Life, he had 'made it my pride and happiness to adopt'. ${ }^{30}$

It was to defend his reputation for naturalness, sincerity, independence, and manliness that Dibdin went to court in 1792-3. His openness, honesty, and independence as a creative artist were a callous deception if his songs were the labours of another passed off as his own. Dibdin's motives during the trials are most clearly displayed in the letters he wrote to the press during these months and the remarkable 'Preface' to the second volume of his Collection of Songs, published in 1792, in which he took the opportunity to explain his conduct. ${ }^{31}$ Contrasting his own sincerity with the public with the duplicity of his enemies, he argues that in seeking to destroy his reputation, they 'knew they could not do so honestly, and therefore they attempted it by villainy'. ${ }^{32}$ Through their accusations, Dibdin complains, they sought to depict him as 'a man void of faith or honour' and 'an impostor', thereby encouraging the public 'not only to damn my works, but my character'. ${ }^{33}$ He refutes the accusation of plagiarism by pointing out how different both his works and his character were from those of Bickerstaff. In the process, he associates Bickerstaff with the antithesis of all the character traits of sincerity and independence that Dibdin so greatly prized. 'Am I enamoured of that insincerity for which he was remarkable and notorious?' Dibdin asks his readers, or 'for that profligacy and immorality which characterised his opinions?'34 'Have I not uniformly rejected all assistance,' he continues, 'nay the assistance of much better poets than he-and did not he court assistance from any body who would lend it him? Were not the suggestions of Goldsmith, Kelly, Garrick, nay even SHUter, and many others, caught at by him with avidity?' 35 Far from Dibdin being the plagiarizer, it is Bickerstaff whose life and work are a fraud upon the public.

Furthermore, as Dibdin liked to insist, this press slander had been caused by his own determined, independent stance. It was his refusal to give 'the editors of newspapers, or their understrappers, general tickets' that produced these 'contemptible paragraphs'. ${ }^{36}$ In this opinion he was vehemently reinforced by William Woodfall in The Diary, who asserted 'Mr. Dibdin has boldly broken through the paltry practice of sending free-admission tickets to every petty scribbler in a newspaper; and to this circumstance we may fairly ascribe all the scurrility of one or two of our daily prints. ${ }^{37}$ This was also the main argument given in court; Dibdin's lawyer at the trial of Swan and Bostock argued that 'no other reason

29 Morning Chronicle (14 January 1789); Morning Herald (17 January 1789); The World (9, 16, and 21 May 1789, 15 November 1790); Diary (26 and 29 March 1791).

30 Life, 4:328.

31 Dibdin's letters to Diary (23 March and 18 October 1792); Charles Dibdin, 'Preface' to A Collection of Songs, Selected from the Works of Mr Dibdin, 2 vols (London, 1792), 2:v-xv.

32 Dibdin, 'Preface', 2:vi. 33 Ibid., 2:vii. 34 Ibid., 2:xii.

35 Ibid., 2:x-xi. $\quad 36$ Dibdin's letter to Diary (18 October 1792). 37 Ibid. 
could be assigned for this conduct than that he [Swan] had been refused a free admission-ticket to the Sans Souci. ${ }^{38}$ As both a refutation of plagiarism and of the practice of giving free tickets to ensure favourable reviews, the trials were a forceful attempt by Dibdin to assert his independence and honesty to the public.

Yet, at the same time, they also underlined his very dependence upon the public for support, since by suing for damages Dibdin was forced to demonstrate that the harm caused by such paragraphs to his reputation had led to loss of income from the public. His indictment of Swan states that the paragraphs had conveyed insinuations injurious to the fair fame and character of the Plaintiff, by endeavouring to ruin him in the opinion of the Public on which he altogether relied, for present subsistence and future fortune’. On this basis, Dibdin requested $£ 2,000$ damages (in the end, he was awarded a still generous sum of $£ 200$ ). ${ }^{39}$ This, plus the fact that witnesses at the trials had an unfortunate habit of revealing that he had retained the practice of giving free tickets to some favoured journalists, while selectively refusing others, ${ }^{40}$ meant that Dibdin felt compelled to issue a series of public pronouncements explaining that he was not suing out of narrow, commercial self-interest, but rather as a principled defender of the public's honour. 'Though I hold it arrogant and reprehensible lightly to obtrude private grievances on the public,' he wrote in a public letter to The Diary, 'yet I could have no sense of the benevolence that supports and protects me, if I did not with manliness and determination resist an insult in this instance offered more to them than to me. ${ }^{\prime 41}$ He could quite happily have ignored the 'noisome stuff', he claimed disingenuously in the 'Preface' to his song collection, 'but it has annoyed the public, and therefore it is my duty to put on the extinguisher'. ${ }^{42}$ Dibdin thus acknowledged his close and intimate relationship with the public, but recast his role from that of dependant to that of defender of the public's honour. Both Dibdin's determination to go to the expense of prosecution and the rhetorical spin that he put upon his motives for doing so demonstrate the importance to him of maintaining his reputation for sincerity, honesty, independence, and manliness before the public. They are a telling sign of the importance of persona, of celebrity, to Dibdin's solo shows, perhaps to a greater extent than any other contemporary performer, given the intimacy and individuality upon which his performances were based. Moreover, appreciating the performance of personality in which Dibdin engaged also holds the key to understanding the political resonances surrounding these trials and the wider brand of loyalist politics that Dibdin espoused.

\section{THE POLITICS OF PERSONALITY}

In the febrile political climate of 1792-3 areas once considered far from politics, such as private life and personal character, were acquiring increasing significance in public debate. As John Barrell has noted, the Royal Proclamation against Seditious

38 Diary (26 June 1793).

41 Diary (18 October 1792).
39 Diary (20 May 1793).

42 Dibdin, 'Preface', 2:v.
40 Diary (26 June 1793). 
Writings in May 1792 and later the Two Acts of 1795 led to a 'sense that everything had suddenly been or could suddenly become politicized... Activities and spaces which had previously been thought to be private, in the sense not just that they were "outside" politics but were, by general agreement, positively insulated from it, suddenly no longer enjoyed that protection. ${ }^{43}$ Adopting a broader perspective, Matthew McCormack has observed the increasing emphasis placed in the second half of the eighteenth century upon an understanding of politics, and especially the contrast of loyalty and disloyalty, as intrinsically tied to emotional expression and states of feeling. ${ }^{44}$ In this environment, Dibdin's particular brand of loyalism, advocated most especially through his songs at the Sans Souci, was underwritten by the supposed naturalness, sincerity, independence, and manliness of the performer. If this persona could be shown to be false, then the loyalist sentiments Dibdin advocated might equally become insincere, unnatural, servile, or effeminate. More was at stake, therefore, in Dibdin's defence of his reputation than simply his own commercial interests.

To appreciate this, we need to pin down the precise nature of Dibdin's loyalism. As Isaac Land explores in Chapter Eleven of this volume, a Victorian caricature of Dibdin's politics, based on a nostalgic reading by conservative moralists of only a small part of Dibdin's oeuvre, primarily the sea songs, has proved widely influential in cementing the impression among subsequent scholars that Dibdin was a highly effective part of the government's propaganda machine. He has even been branded by some as 'the real laureate of the Great Terror', supposedly orchestrated by Pitt's government in these years. ${ }^{45}$ Recently, however, a more rounded picture of Dibdin's politics has begun to emerge, which has suggested a much more equivocal stance towards the government and its policies. ${ }^{46}$ This has underlined not only the need to examine the full range of Dibdin's works, but also to recognize these works not simply as texts, but as performances, in which the personality of the performer and the interrelationship between the songs and anecdotes in an evening's performance all had a role to play in shaping a rather different brand of loyalist sentiment. So far, this new research has largely focused on the period after 1803, when Dibdin was directly employed by the government to write 'war songs'. As we shall see, this ambivalence and his resistance to toeing the government line were already important themes of Dibdin's politics during the 1790s and earlier.

On the face of it, Dibdin's songs are avowedly loyalist in their sentiments. Indeed, Dibdin boasted that his songs were so persuasive regarding the duties of

43 John Barrell, The Spirit of Despotism: Invasions of Privacy in the 1790s (Oxford: Oxford University Press, 2006), 4.

44 Matthew McCormack, 'Rethinking "Loyalty" in Eighteenth-Century Britain', Journal for Eighteenth-Century Studies 35/3 (2012): 407-21, esp. 416-19.

45 Originally coined by H. F. B. Wheeler and A. M. Broadley, Napoleon and the Invasion of England: The Story of the Great Terror, 2 vols (London: John Lane, 1908), 2:293, this epithet has recently been repeated by Mark Rawlinson, 'Invasion! Coleridge, the defence of Britain and the cultivation of the public's fear', in Philip Shaw (ed.), Romantic Wars: Studies in Culture and Conflict, 1793-1822 (Aldershot: Ashgate, 2000), 124, while a similar interpretation is offered by Ian Dyck, William Cobbett and Rural Popular Culture (Cambridge: Cambridge University Press, 1992), 88.

46 Cox Jensen, Napoleon, 19, 56-9. 
servicemen and loyal subjects that they could instantly quell mutinies upon being sung to the troops. ${ }^{47}$ Moreover, there is evidence to suggest that Dibdin intensified his overtly loyalist writing during 1792-3. In one of the anecdotes from The Quizzes; or, a Trip to Elysium, the solo show that he performed during that autumn and winter, he used a characteristic nautical metaphor to argue that the ship of state cannot sail upon the principle of absolute equality. As a sailor explains, equality is 'a thing you see that canot $[s i c]$ easily be-Englishmen are equally brave, equally honest, and equally loyal but as for the rest the boatswain to the rigging and the purser to the slops ... whether the vessel be a ship or a kingdom-She canot expect to make a prosperous voyage - unless all the crew keep their proper station. ${ }^{48}$

In his songs from these months too, the same sentiments can be traced. 'The Compact of Freedom', which he first performed in late November 1792, directly advocates loyalty, which Dibdin portrays as the foundation of British liberties:

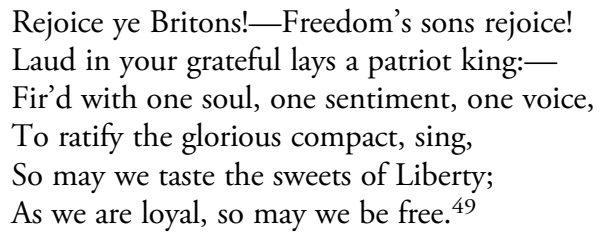

To emphasize and facilitate the song's association with the patriotic defence of the nation, the published score features accompaniments for a military band of clarinets, horns, and bassoons. Appearing amidst the fervour of the loyalist reaction, spearheaded by the foundation of John Reeves's Association for the Preservation of Liberty and Property against Republicans and Levellers in November 1792, the song was praised by The Diary as a 'timely sacrifice to loyalty', while a later issue felt it to be akin to an 'oath of allegiance' embodying the sentiment that 'Britons are free only in proportion as they are loyal'. ${ }^{50}$ Another song, 'Ninety Three', written to mark the start of the new year, was similarly lauded in the press for its loyal sentiments. ${ }^{51}$ It is striking for being one of the few songs in Dibdin's corpus that directly attacks the principles of the French Revolution:

Some praise a new freedom, imported from France,

Is liberty taught them like teaching to dance?

They teach freedom to Britons! our own right divine!

A Rush-light might as well teach the sun how to shine.

In famed ninety three

We'll convince them we're free

Free from every licentiousness faction can bring

Free with heart and with voice to sing God save the King. ${ }^{52}$

47 Life, 1:8.

48 BL, Add. MS 30962, C. Dibdin Table Entertainments, vol. 3, f. 95v. For another example, see ibid., f. 9 .

49 Charles Dibdin, 'The Compact of Freedom' (London, [1793?]).

50 Diary (3 and 10 December 1792). $\quad 51$ Diary (3 January 1793).

52 Charles Dibdin, 'Ninety Three' (London, [1793?]). 
Most striking is the fact that, amid a background of rising political tensions and impending war with France, reviewers were eager to interpret the success of these songs as signs that the sentiments contained within them naturally coincided with the feelings of Dibdin's audiences. The audience, recorded one paragraph in the Morning Chronicle, 'always require a repetition of the song ["The Compact of Freedom"], [so] that sentiments, so congenial to their feelings, should be the more forcibly impressed on their minds'. ${ }^{53}$ The Diary, meanwhile, reflected that 'in the present moment every touch at the times becomes in some degree interesting; and the operation of a mere song on the feelings of a mixed and causual [sic] audience, may form a tolerably true test of their real sentiments'. The writer then goes on to note that 'Ninety Three' had been encored (almost twice) and called for again at the end of the evening. ${ }^{54}$

This desire to record the visible effects of such patriotic songs upon the feelings of audiences attests to an anxious impulse to associate such sentiments with the natural and sincere feelings of the British people. However, the fact that it was the Whig reformist Morning Chronicle, rather than any pro-ministerial print, that proved the most vocal admirer of a song such as 'The Compact of Freedom' should alert us to the fact that Dibdin's patriotism could be read in far from straightforwardly 'loyalist' ways. Indeed, while he was keen to exploit the loyalist mood for commercial gain, for Dibdin this did not entail a servile kowtowing to the government. His language of loyalty was continually underpinned by assertions of independence — of independent judgement and feelings leading naturally to loyalist sympathies — rather than simply following what the government instructed people to think. As Mark Philp and others have shown, he was not alone in adopting such a position, but he presented an especially forceful articulation of this way of thinking. ${ }^{55}$

This 'independent loyalism' is most noticeable in his strongly critical stance towards those in authority, frequently accusing them of corruption and hypocrisy. Much of this material can be traced back to his earlier journalistic work in publications such as The Devil (1786-7) or The By-Stander (1789-90). Both periodicals took a very dim view of politicians; in Chapter Four of this volume David O'Shaughnessy discusses The Devils criticism of William Pitt and especially the Commercial Treaty with France (1786), but politicians of all stripes were subjected to withering criticism. ${ }^{56}$ Moreover, alongside this irreverence towards politicians, these periodicals attacked other familiar targets: the aristocracy and the Church. The By-Stander contains an essay calling for aristocratic titles to be based on personal merit rather than inherited privilege. It concludes, 'Since then high birth imposes an obligation to possess great merit, it ought rather to inspire diffidence and modesty, than haughtiness and pride. Thus to many has nature been very cruel; for not contented with refusing

53 Morning Chronicle (10 December 1792). $\quad 54$ Diary (3 January 1793).

55 Mark Philp, 'Vulgar Conservatism, 1792-3', English Historical Review 110 (1995): 42-69, and Donald E. Ginter, 'The Loyalist Association Movement of 1792-3 and British Public Opinion', Historical Journal 9/2 (1966): 179-90.

56 Devil, 1:93; 2:148-52, 194-200; By-Stander, 2, 10-11, 31-2, 141. 
them every kind of merit, she has taken care they should be well born. ${ }^{57}$ Meanwhile, the periodical played with particular relish upon another stock trope in a poetic account of the behaviour of a greedy prelate who invites a poor curate to a truly gargantuan dinner:

As he [the bishop] sipt, and turn'd over each morsel he eat [sic]

Of the jellies, and trifles, and ices, and whips,

Which seem'd pleas'd to salute his right rev'rend lips,

Scarcely deigning to cast on the curate his eyes,

He belch'd out - 'here mister — nay friend do not rise,

I was going-Jack give me some wine-do you see,

To ask of what value your living may be?'

The curate, who sat all the time and admir'd

And eat from this feast just what nature requir'd,

Full of innocence, answer'd him pat at a word-

'Just as much as your bishopric, rev'rend my lord:

If the measure we hold of our consciences even,

Both rewards will be great-for our treasure's in heaven. ${ }^{5} 8$

One satire in particular brought many of these themes together into a far-reaching condemnation of Britain's contemporary ruling elite. The second volume of The Devil contains a serialized account of a circumnavigator's 'Trip to the Antipodes of England', the conceit of which is that Antipodean society is the inverse of that of England. In the Antipodes, all is corrupt and dissolute, whereas England, the narrator continually reminds the reader, is a paragon of moral perfection. Antipodean bishops, for instance, are portrayed as grasping after 'plurality of benefices', while their ministers of state show a total disregard for the 'public good'. 'But is it so in England?' Dibdin's narrator asks:

Oh no-the bishop there lolls in no unfeeling splendour, deaf to the petitions of miserable curates and large families... Nor is the Antipodean statesman less a foil to the English one, who-GLORIOUS CHARACTER — has the good of his country constantly at heart-who never makes a promise but he keeps, never betrays the public for his private views, never encourages the flattery of sycophants, never abuses his master's confidences, never merits the execration of the people; ... he makes no blunders, levies no unreasonable or oppressive taxes, frames no unwholesome laws, nor does any one thing either partial, rigorous, puerile, ineffectual, ungenerous or unjust. ${ }^{59}$

Crucially, these themes of gluttonous bishops, corrupt politicians, and oppressive taxes were not confined to Dibdin's journalism of the late 1780s, but remained a vibrant and much discussed theme of his solo shows throughout the crisis years of the 1790s. 'The Trip to the Antipodes' story from The Devil, for instance, was reworked as the basis of Dibdin's show for the 1794-5 season, Great News; or a Trip to the Antipodes. One reviewer in The Oracle observed that the show relayed the 'great news ... that, at the Antipodes, people practise every vice and folly; and, in England, every thing sensible and good'. 'The irony generated by this idea', the

57 By-Stander, 135, $137 . \quad 58$ Ibid., $128 . \quad 59$ Devil, 2:73-5. 
journalist remarked, 'is pleasingly new, and had a most pleasant effect,' while the songs were 'more pointed and marking than any Mr. DiBDIN had before produced'. ${ }^{60}$ This reviewer's comments may refer more to the social satire contained in these songs, since (at least in the versions subsequently published by Dibdin) their lyrics are not obviously political. Instead, it would seem that Dibdin's political satire was mostly confined to the anecdotes that threaded the songs together. A close comparison of the satire quoted above from The Devil with the (unfortunately fragmentary) manuscript documents in the British Library which appear to be Dibdin's performance notes reveals a close resemblance of theme and political resonances. ${ }^{61}$ This contrast between anodyne songs and politically biting anecdotes is no contradiction, but rather a careful strategy; the anecdote, in comparison to the printed text of a song lyric, was safely evanescent and thus the ideal medium in which to convey material that might irritate the authorities. The moment of performance therefore permitted a wider range of political stances to be adopted than published texts of those performances imply.

The political uses of the anecdote can be seen in another example from the previous season's show, Castles in the Air, in which Dibdin used an impersonation of the innocence and simplicity of a country bumpkin to offer a comic satire of authority figures in rural society. Asked what he had seen on a trip to the capital (in which he appears to have visited the exotic animals kept at the Tower of London), the rustic replies:

Why nought but what I had zeed before. I sawed the wild beasts; there were a bear that I wish I may die if I did not take for our parson; and, as to the monkies, I a zeed a whole posse of sutch as they go to dinner at the Squires. The man shewed me a Hyena, I think twas, and he twold me that he seizes upon people and so moans over em, as if he were sorry to eat them up. I said that were nothing at all; for that, about our village, we had the same sort ... but we call em lawyers and excisemen; that seizes upon people too, but, so far from making bones about the matter, they eats them up without being sorry at all. ${ }^{62}$

Such complaints about greed and corruption in high places and of the harsh burdens of heavy taxation, far from casting Dibdin as the 'real laureate of the Great Terror', instead bring him much closer in sympathy with the work of more radical songwriters such as John Freeth, a member of a Jacobin club that met at his public house in Birmingham, who likewise highlighted government corruption and the miseries of heavy taxation in his highly popular political songs. ${ }^{63}$ Dibdin and Freeth also shared a patriotic identification with ordinary soldiers and sailors, praising their heroism in service to the nation. ${ }^{64}$ Yet there were important differences too. Dibdin never strayed anywhere near the radicalism of Freeth's song 'Blood Royal':

60 Oracle (13 October 1794)

61 BL Add. MS 30960, C. Dibdin Table Entertainments, vol. 1, f. 142v.

62 Ibid., ff. 45-46.

63 John Horden, John Freeth (1731-1808): Political ballad-writer and innkeeper (Oxford: Leopard's Head Press, 1993), 8-9, 14, 24-5.

64 See, for example, ibid., 150-1 ('British Volunteers'), 161-2 ('Britain's Glory'), 200 ('The Tars of Old England'). 
The blood which some boast of, from this or that quarter,

A Knight of the Thistle, or Knight of the Garter,

Was ne'er any better, or is at time present,

Than what freely flows in the veins of a PEASANT;

'Twixt that of a MONARCH and that of a BEGGAR,

When shed to distinguish a DOCTOR 'twould stagger. ${ }^{65}$

Rather, the collective effect of Dibdin's work is to suggest that the British constitution and social order remain the best guarantors of liberty and happiness, but that those in power are too often guilty of failing to live up to the high standards required to maintain the nation's dignity and strength. Such indictments are perhaps at their most damning in his numerous sea songs that draw contrasts between hard-working, honest Jack Tars, and aristocratic officers more concerned with making a dashing fashion statement in their military regalia than with defending the nation. ${ }^{66}$

This interpretation sets Dibdin's government pension, which might otherwise reinforce the idea of Dibdin as a key part of the ministerial propaganda machine, in a new light. The details of this $£ 200$ pension, awarded in June 1803 , remain unclear, and our only substantial source is a self-justificatory pamphlet, published by Dibdin in 1807, in protest at its revocation by Lord Grenville's 'Ministry of all the Talents' ${ }^{67}$ While he makes little secret of his willingness to accept a pension, Dibdin's portrayal of his motives for doing so suggests this was hardly born out of a desire to serve the government's interests. In the first place, as he repeatedly observes, he was simply being pragmatic; now in his late fifties, and with retirement increasingly desirable, such a pension would secure a comfortable old age. ${ }^{68}$ Furthermore, he clearly implies that being known to be in the pay of the government could only harm his future commercial prospects. Even before receiving the pension, he was already suffering, he claims, from a reputation for being 'outrageously loyal'. 'People were tired with what they called being schooled by me', he wrote, 'when they ought to be considered as competent to judge for themselves.' 69 Evidently, Dibdin was well aware that to divert from the 'independent' style of loyalism through more outright support for a particular ministry was to risk public displeasure. In addition, rumours that he was a government agent had previously done severe damage to his commercial success in the more disaffected parts of the provinces and, unsurprisingly, in post-Rebellion Ireland..$^{70}$ Of course, he had a strong interest in portraying himself as having suffered in the loyalist cause, but his demand for a regular annuity was in part, as he suggested, to offset the losses he anticipated making on the British War Songs series that the government desired him to write, since he feared they would be 'scouted' by the public. ${ }^{71}$ In confirmation of

\footnotetext{
65 Ibid., 179.

66 For examples, see D. A. B. Ronald, Youth, Heroism and War Propaganda: Britain and the Young Maritime Hero, 1745-1820 (London: Bloomsbury, 2015), 126-7.

67 Charles Dibdin, The Public Undeceived, written by Mr Dibdin; and containing a statement of all the material facts relative to his pension (London, [1807]).

68 Ibid., 11-12, $25 . \quad{ }_{69}$ Ibid., 16. 70 Ibid., 12-13, $18 . \quad{ }^{71}$ Ibid., 21.
} 
this prophecy, his entertainment, Britons Strike Home, based on these 'war songs', ran at a 'very heavy loss'. ${ }^{72}$ His awareness that obviously propagandistic works did not sell well is also apparent in the songs themselves, which, as Oskar Cox Jensen notes, display a remarkable reluctance to engage in the kind of savage Francophobia and demonization of Napoleon common in the more straightforward loyalist propaganda songs of the era. ${ }^{73}$

Above all, Dibdin sought to persuade the public that he was entitled to a pension, not because of his pandering to the whims of a particular minister, but as a reward for loyal service to the nation and to the public. To make this point, he cites testimonials from members of the public, such as a group of gentlemen of Yarmouth, who had written to him stating their belief he should be rewarded in some way. ${ }^{74} \mathrm{He}$ compares his situation to that of Greenwich and Chelsea pensioners, or to literary figures such as Dr Johnson, who were rewarded with a comfortable retirement for their duty to the national interest. ${ }^{75}$ In particular, he insists he is no sinecure-hunter, comparing his deserving situation to that of the cronyism that, he implies, had surrounded Grenville's ministry. Indeed, he hints that it was the number of 'candidates for private favour' clamouring at the Treasury door during Grenville's time in office that had forced the government to cancel Dibdin's reward for his public services. ${ }^{76}$ At times, he even adopts the language of reform, declaring 'the burdens of the people call loudly and imperiously for every exercise of economy' and 'the most diligent care ought to be taken that the public money is not lavished away' on individuals who did not truly merit such reward. ${ }^{77}$

While much of this may well be a desperate attempt to save a public reputation in tatters by a performer now forced by the cancellation of his pension to return from retirement to the stage, it is nonetheless significant that he chose to do so by insisting he was the same, independent-minded loyalist in 1807 as he had been back at the height of his success in 1792-3. Far from indicating his closeness to the government, this episode reveals on the one hand an unsurprising, self-interested pragmatism with an eye towards retirement, and on the other a firm and continuing belief that writing straightforward ministerial propaganda could only lead to commercial failure.

72 Ibid., 25.

73 Cox Jensen, Napoleon, 57-9. Another possible example of Dibdin's propagandistic work from this period is a fragmentary manuscript held in the Theater Collection at the Houghton Library, University of Harvard (MS Thr 198.55), which appears to be a rough draft of a pamphlet or public address Dibdin was preparing during his years as a government pensioner. Although fairly incoherent, it exhorts British subjects to show loyalty to their king, know their place, and perform their duty, while roundly condemning all schemes for reform of the constitution. Nonetheless, it too avoids any Francophobia or demonization of Napoleon, preferring instead to focus on British 'virtue' and the blessings of British laws, which, Dibdin reminds his audience (and indeed any potentially over-mighty government ministers), were 'formed for the security of us all nor can any be above or below them' (f. 2).

74 Dibdin, Public Undeceived, 14-16. $\quad 75$ Ibid., 33-4, 50-2.

76 Ibid., 50. 


\section{INDEPENDENT LOYALISM}

Recognizing this persistent 'independent' strain to Dibdin's loyalism furthers our understanding of the complexities of political culture in the 1790s in important ways. Through his performance of personality, he was competing with radicals and reformers, who also liked to claim their cause was supported by their openness, sincerity, and independence, in the face of government duplicity and repression. Jon Mee has observed that radicals focused intensely on the issue of sincerity and openness in their conversation as a defiant response to government attempts to police private speech through the Gagging Acts. ${ }^{78}$ Yet the natural sincerity of the persona Dibdin projected in his performances suggests attempts from a loyalist perspective to claim and contest the politics of openness and genuine feeling. Equally, Matthew McCormack has portrayed radicals and reformers as the most vocal proponents of 'manly independence' in the first half of the 1790s, offering it as a sign of the integrity and virtue of their political critique. Meanwhile, he argues, loyalists were unable to do anything more compelling than reiterate the merits of dependency and hierarchy, as epitomized by Hannah More's Village Politics. ${ }^{79}$ Dibdin's brand of loyalty, however, was inseparable from his public persona of manly independence. In contrast to the passive obedience encouraged by many loyalist propagandists, Dibdin offered a means for individuals to affirm their loyalty to the constitution and social order while refusing to surrender their right to criticize those charged with the administration of it. If the popularity of his entertainments and the wide circulation of his songs is anything to go by, it was a recipe that proved highly successful with the public.

It was this that made Dibdin's defence of his personality through the libel trials all the more pressing. Accusations of plagiarism undermined Dibdin's claim that his songs were the outpourings of natural feeling and independent loyalist sympathies. Instead, they became an open deception, their ability to persuade the public of the virtue of the loyalist cause undermined by their revelation as the work of a known sodomite. Indeed, the insinuations of sodomy slung at Dibdin also contained political overtones. Dibdin was not the only actor in this period to have been accused of improper relations 'behind the curtain', the very same phrase also appearing in William Jackson's poem, Sodom and Onan, which accused Samuel Foote of committing the same offence. ${ }^{80}$ As Matthew Kinservik and others have shown, in Foote's case and in other high profile accusations in this period, sodomy was particularly associated with corruption and cover-ups in high society and government. ${ }^{81}$ Hence the charge levelled by Swan at Dibdin, that he was 'backed by some persons of fame and Notoriety', may well have had a particular resonance.

\footnotetext{
78 Jon Mee, Conversable Worlds: Literature, Contention, and Community 1762 to 1830 (Oxford: Oxford University Press, 2011), Chapter Three.

79 Matthew McCormack, The Independent Man: Citizenship and Gender Politics in Georgian England (Manchester: Manchester University Press, 2005), 2, 120-47.

80 William Jackson, Sodom and Onan, a satire (London, 1776), 7.

81 Matthew J. Kinservik, 'The Politics and Poetics of Sodomy in the Age of George III', British Journal for Eighteenth-Century Studies 29/2 (2006): 219-36; Charles Upchurch, 'Politics and the
} 
As his entanglements in the politics of personality show, interpreting Dibdin and the contemporary political culture he inhabited cannot be done through a purely textual analysis. Instead, we must appreciate the nature of his works as performances in which the person speaking, the manner of delivery, and the juxtaposition of texts as part of an evening's bill of fare mattered as much as the words spoken. This approach uncovers more fully the nature of Dibdin's 'independent loyalism' and its part in the complex interweaving and contesting of political languages of sincerity and independence, loyalism and reform. In doing so, it highlights the public's antipathy towards overt government propaganda. For Dibdin's audiences, loyalty to King and Constitution had to be carefully packaged alongside clear criticism of the government and the ruling elite if it was to be persuasive, commercially successful, and popular. His stance makes the so-called 'loyalist reaction' after 1792 seem a lot less sure-footed, dominant, and pro-ministerial than some historians have suggested. ${ }^{82}$ Instead, the appeal of Dibdin's performance of loyalism appears contingent upon fragile, and thus carefully defended, claims to speak independently, critically, and honestly to the public. With its cutting edge of social and political satire, and its sense of discontent and distrust of authority, Dibdin's loyalism was far removed from the aims of other prominent loyalist organizers and writers. ${ }^{83}$ As such, it lends further weight to the arguments of Philp and others about the profound diversity of uses for the language of loyalty in the $1790 \mathrm{~s} .{ }^{84} \mathrm{In}$ short, while Dibdin's mastery of the politics of personality and the appeal of his brand of critical 'independent loyalism' made the job of those seeking to win support for more radical measures of reform more difficult, it was far from easy listening for anxious ministers and their allies struggling to keep the public onside in a tumultuous decade of war and revolution.

reporting of sex between men in the 1820s', in Brian Lewis (ed.), British Queer History: New Approaches and Perspectives (Manchester: Manchester University Press, 2013), 17-38; A. N. Gilbert, 'Sexual Deviance and Disaster during the Napoleonic Wars', Albion 9/2 (1977): 98-113.

82 See H. T. Dickinson, British Radicalism and the French Revolution 1789-1815 (Oxford: Blackwell, 1985), Chapter Two; Frank O'Gorman, 'Pitt and the "Tory" Reaction to the French Revolution 1789-1815' in H. T. Dickinson (ed.), Britain and the French Revolution, 1789-1815 (Basingstoke: Macmillan, 1989), 21-37; Ian R. Christie, 'Conservatism and stability in British society' in Mark Philp (ed.), The French Revolution and British Popular Politics (Cambridge: Cambridge University Press, 1991), 169-87.

83 For comparison with other contemporary forms of conservative opinion, see Kevin Gilmartin, 'In the Theater of Counterrevolution: Loyalist Association and Conservative Opinion in the 1790s', Journal of British Studies 41/3 (2002): 291-328; Jennifer Mori, 'Languages of Loyalism: Patriotism, Nationhood and the State in the 1790s', English Historical Review 118 (2003): 33-58; Michael S. Smith, 'Anti-Radicalism and Popular Politics in an Age of Revolution', Parliamentary History 24 (2005): 71-92.

84 See Philp, 'Vulgar Conservatism'; Philp, Reforming Ideas in Britain, Chapter Three; David Eastwood, 'Patriotism and the English State in the 1790s' in Mark Philp (ed.), The French Revolution and British Popular Politics (Cambridge: Cambridge University Press, 1991), 146-68; Nicholas Rogers, 'Burning Tom Paine: Loyalism and Counter-Revolution in Britain, 1792-1793', Histoire Sociale/Social History 32 (1999): 139-71. 


\title{
6 \\ Dibdin and the Dilettantes
}

\author{
Judith Hawley
}

In 1791, despite revolutions in France and Haiti, the publication of revolutionary texts by Thomas Paine and Mary Wollstonecraft, and the breaking out of the 'Priestley riots' against Dissenters in Birmingham, the London newspapers were full of references to sites where care did not reign or riot. On Wednesday 22 June, the Star reported on the 'HON. MRS. HOBART'S RURUAL [sic] BREAKFAST', which was held the previous Saturday at Sans Souci. The World on 27 September noted, 'SANS SOUCI, et sans six sous, is the old French description of a man careless and happy.' On 6 October, the World reported on the movements of the Prince Stadtholder and his Consort, recording that she was expected to reach New Sans Souci shortly. Two days later, the Morning Post and Daily Advertiser advertised that on 31 October, 'an entirely new, and perfectly original Entertainment' called 'PRIVATE THEATRICALS; Or, NATURE IN NUBIBUS' would be performed at the Sans Souci. These carefree venues were quite different, but all derived from the Schloß Sanssouci, Potsdam, summer palace of Frederick the Great. The New Sans Souci is the grander palace built next to it by his successors, who felt his charming single-storey villa was not majestic enough for them. The first-mentioned Sans Souci, venue of the French pic nic, was a grand villa in Ham near Richmond, home to the Hon. Albinia Hobart, later Countess of Buckinghamshire. The last of these sites was Charles Dibdin's brand new venue: a theatre with reception rooms in the Strand opposite Beaufort Buildings, where he performed his one-man entertainments. The name was appropriate, as Dibdin might have felt that he had cast off all cares when he finally set himself up as Charles the Great: actor, manager, owner, composer, performer - in fact, factotum in his own premises. ${ }^{1}$

While the rural breakfast Mrs Hobart provided for the bon ton in her Richmond Sans Souci was rather different from the entertainment laid on for the paying public

1 Dibdin was earlier associated with the name and with Frederick the Great when he set to music for David Garrick 'Le Philosophe Sans Souci', a poem by Rev. Percy Stockdale, in 1773. See Fahrner, 207n. The shared name may be responsible for the British Museum's misidentification of the print of the interior of Dibdin's second Sans Souci theatre as 'Interior of a palace'. Oskar Cox Jensen has corrected this error (accessed 13 May 2015): http://www.britishmuseum.org/research/ collection_online/collection_object_details.aspx?objectId=3161174\&partId=1\&search Text=sanssouci\&images=true\&page $=1$. Dibdin does not seem to have been entirely confident about the project and had written up above the stage 'LET US ALL BE UNHAPPY TOGETHER' - a line from his song 'Sound Argument'. 
in Dibdin's rooms in the Strand, the two hosts were united by an interest in private theatricals. Dibdin chose this title for the first ever entertainment staged at his new theatre because, as he said, 'private theatricals were the rage'. ${ }^{2}$ By the late eighteenth century, amateurs of all classes were staging theatrical performances in a variety of venues and the trend continued well into the nineteenth century. Albinia, 'Lady Bucks.', was a stalwart of the late-eighteenth-century am-dram scene, appearing in the Duke of Richmond's theatricals in his house in Whitehall in 1787-8, in Elizabeth, Lady Craven's theatricals in Newbury Town Hall in 1780, and in 1793 and 1795 at the private theatre Craven built at Brandenburgh House, Hammersmith after she became Margravine of Ansbach. ${ }^{3}$ When she was cruelly lampooned in verse and cartoon in 1795, she broke with the Margrave and was later a prime mover in setting up the Pic Nic Society, which staged entertainments at the New Rooms in Tottenham Street in $1802-3 .{ }^{4}$ In different ways, Dibdin and the dilettantes were participating in a revolution in theatrical entertainment that would, over the course of the next half-century, overthrow the monopoly of the patent theatres. ${ }^{5}$

Plenty of other things were 'the rage' in 1791, so why did Dibdin gamble on private theatricals in particular as a way of attracting an audience to his experimental venture? And how did he represent them in his one-man show? This chapter will answer those questions and provide a context for Dibdin's show by exploring the craze for private theatricals. It will also attempt to reconstruct the show by examining a previously neglected autograph manuscript. While private theatricals were in some respects a pretext to launch Dibdin's eclectic programme of comic anecdotes, songs, and impersonations (for more on which, see Chapters Seven and Eight in this volume), the subject also provided an opportunity for him to reflect on class, gender, nation, and performance in the context of the aesthetically and socially mixed economy of the London theatre world at the turn of the nineteenth century.

2 BL Add. MSS 30961, f. 9r. This MS is unnoticed by Fahrner in his account of Dibdin's career. All quotations from this manuscript are (C) The British Library Board.

3 For the Margravine, see Judith Hawley, 'Elizabeth and Keppel Craven and The Domestic Drama of Mother-Son Relations', in Elaine McGirr and Laura Engell (eds), Stage Mothers: Women, Work and the Theatre 1660-1830 (Lewisburg: Bucknell University Press, 2014), 199-216.

4 For an overview, see Sybil Rosenfeld, Temples of Thespis: Some Private Theatricals in England and Wales, 1700-1820 (London: Society for Theatre Research, 1978); for more recent studies that challenge some of her findings, see Judith Hawley and Mary Isbell (eds), Amateur Theatre Studies, a special issue of Nineteenth Century Theatre and Film 38/2 (2011). See also Gillian Russell, 'Private Theatricals', in Moody and O'Quinn, Companion to British Theatre, 191-203. For the Pic Nic Society, see Richard L. Lorenzen, The History of the Prince of Wales Theatre, 1771-1903 (Hatfield: University of Hertfordshire Press, 2014), 13-20. James Gillray commemorates Mrs Hobart's appearance as Cowslip in Lady Craven's Brandenburgh House theatricals in 'Enter Cowslip with a Bowl of Cream' (1795). He frequently satirized her extravagant entertainments and her rotund figure. She appears in his series of caricatures of the Pic Nic Society: 'The Pic-Nic Orchestra' (1802); 'Blowing Up the PicNics;-or-Harlequin Quixotte attacking the Puppets' (1802) and 'Dilettanti Theatricals;-or-A Peep at the Green Room' (1803). She also appears in his satires on gambling ladies mentioned in Note 17 below. Her husband George Hobart also had an interest in the theatre: he managed the opera at the King's Theatre, Haymarket, and their daughter Albinia married the son of George Cumberland, playwright. See Matthew Kilburn, 'Hobart, George, third earl of Buckinghamshire (1731-1804)', ODNB (accessed 13 May 2015), http://www.oxforddnb.com/view/article/13390.

5 On this long battle, see Moody, Illegitimate Theatre. 


\section{THE CRAZE FOR PRIVATE THEATRICALS}

The most notorious eighteenth- and early-nineteenth-century private theatricals were those staged by social elites in their grand country houses and London mansions. Several aristocrats, including the Duke of Richmond, the Earl of Barrymore, Sir Francis Drake Delaval, the Duke and Duchess of Marlborough, and the Margravine of Ansbach, each put on a magnificent show. Some of them poured their money into buildings that rivalled the London theatres. Indeed, the theatre of Richard, Earl of Barrymore at Wargrave, Berkshire, was modelled on the King's Theatre, Haymarket. He, like other amateur impresarios, employed London craftsmen as well as actors, dancers, and musicians. The results were impressive: when the bankrupt Barrymore's theatre was broken up and the materials were auctioned off, professional theatres snapped them up. ${ }^{6}$ Private theatricals imitated the patent theatres in other ways: they staged full bills of entertainment and circulated printed playbills and tickets. In other respects, they went beyond the provisions of the London theatres, providing suppers and balls; they were social events as well as dramatic entertainments. The very name of the Pic Nic Society indicates how important feasting was to their entertainment (pic nic meant what we might now call a pot-luck supper to which everyone has to contribute a dish, rather than an al fresco meal). On 3 April 1793, after the grand opening of her new theatre at Brandenburgh House attended by the Prince of Wales, the Margravine of Ansbach threw a masquerade ball and even provided costumes for all one hundred and twenty guests. As well as a theatrical performance, this exercise in conspicuous consumption performed the function of managing social power. The Margravine employed her theatricals to re-establish her position after her notorious infidelity to her first husband, the Earl of Craven, had diminished her social credit. Theatricals were also a continuation of a tradition of country-house entertainments, ostentation, and sociability. When the nobility returned to their estates at the end of the season, bringing the conventions of the London stage and their enormous spending power with them, country-house theatricals also played a role in the integration of regional and metropolitan culture. In many cases, such as the theatricals at Wargrave and Wynnstay, servants and locals were drafted in as performers and audience. Thus, argues Gillian Russell, gentlemen such as Sir William Watkins Wynn dramatized the 'dynamics of power between master and servant in the Georgian household'. Such events, Russell argues, staged 'not simply a series of lavishly produced plays but theatre's capacity to mimic and realise the conditions of the eighteenth-century social order itself'?

What was the attraction of these theatricals for the participants? First of all, precisely that: participation-crossing the line between spectatorship and action. Moreover, women had opportunities to participate in a wider range of capacities on

\footnotetext{
6 Rosenfeld, Temples, 32-3. Rosenfeld reproduces the bills Edward Hartopp-Wrigley incurred over the years in constructing and improving his theatre at Little Dalby Hall, 1777-1804 (ibid., 146-53). The private theatres at Blenheim, Woburn Abbey, and Brandenburgh House were also magnificent.

7 Russell, 'Private Theatricals', 195, 196.
} 
the amateur stage. As well as acting and making costumes, they could design décor, write plays, direct rehearsals, and manage the venue. The Margravine of Ansbach is the prime example of an amateur impresaria, but others, including the Dowager Lady Townsend, Mrs Hickford, Mrs Crespigny, Mrs Hobart, the Duchess of Rutland, and Mrs Damer, also played significant managerial roles in private theatricals, building on and extending their domestic functions. Men too could extend their roles: cross-dressing in private theatricals was common, especially in the armed forces and other single-sex establishments. ${ }^{8}$ It might have expressed a predilection as well as a necessity.

It also exemplifies the boundary-crossing nature of private performance. Whereas in the professional theatre there are complex cultural, conceptual, and commercial distinctions between those on the stage and their paying audience, there is much less of a divide between performer and spectator in private theatricals. They are usually drawn from the same social—and sometimes even family — group, and their familiar roles might bleed through their theatrical ones as in a palimpsest or pentimento. ${ }^{9}$ Of course, traces of the former roles of professional actors, or details of their private lives, may affect the audience's reception of their current character, but the effect is likely to be more intense and more part of the pleasure in amateur performance when the actors are known personally to the audience. Those on both sides of the curtain might be called on to perform: the Pic Nic Society determined 'to meet once a fortnight, to enjoy the amusements of acting, music, and dancing, and to conclude with a supper, and catches and glees'; the audience, all of whom were members of the Society, were expected to participate in the singing as well as providing refreshments. ${ }^{10}$ Everyone had to bring something to the entertainment.

A further attraction was privacy. The upper classes could avoid the exposure to the masses that they had to suffer in the vast auditoria of the patent theatres. Even the private boxes that prompted the OP riots were not private enough for them. ${ }^{11}$ They wanted total control over the tickets. Written into the Rules and Regulations of the Pic Nic Society was the stipulation that admission was by ticket or invitation card only, a fixed number of which were issued to each subscribing member: 'The Ladies Patronesses to have on their List Ten Ladies and Ten Gentlemen; the rest to be recommended by the Director', and 'Members going abroad not to transfer their tickets'. ${ }^{12}$ A similar system was in place at the Richmond House Theatricals in

8 See Mary Isbell, 'The Handwritten Playbill as Cultural Artifact: A French Amateur Theatrical Aboard the British Prison Ship, Crown', Inquire: A Journal of Comparative Literature 1 (2011), (accessed 13 May 2015), http://inquire.streetmag.org/articles/40; Mary Isbell, 'When Ditchers and Jack Tars Collide: Benefit Theatricals at the Calcutta Lyric Theatre during the Indian Mutiny of 1857-9', Victorian Literature and Culture 42 (2014): 407-23; and Michael Dobson, Shakespeare and Amateur Performance: A Cultural History (Cambridge: Cambridge University Press, 2011), esp. 123-51.

9 See Marvin Carlson, The Haunted Stage: The Theatre as Memory Machine (Ann Arbor: University of Michigan Press, 2001). I am indebted to Mary Isbell for this suggestion.

10 'Proposed Rules for the Pic Nic Society', in The Pic Nic (London, 1803), 1:xxiv. Only one volume of this projected serial was produced.

11 See David Worrall, Theatric Revolution: Drama, Censorship and Romantic Period Subcultures 1773-1832 (Oxford: Oxford University Press, 2006), esp. 13, 227-32; and Marc Baer, Theatre and Disorder in Late Georgian London (Oxford: Clarendon Press, 1992).

12 The Pic Nic, 1:xxiv. 
1787. The Duke was determined to keep the party select 'by devising an elaborate system of invitations to avoid "the intrusion of improper company" and by vetting the guest list the day before the performance. ${ }^{13}$ Examples of this sort could be multiplied. Indeed, for some people the main motive for participation in private theatricals was to receive tickets for an exclusive event which could then be distributed as a form of patronage. ${ }^{14}$

Some praised private theatricals, claiming that the intimate setting fostered a more nuanced acting style than was possible in the patent theatres or attempted in the minor theatres. However, as Helen Brooks notes, it is impossible to judge the quality of amateur acting at this period, as negative reviews of private theatricals might have been motivated by the threat of competition they posed to professionals, while positive ones might have been placed by the performers themselves. ${ }^{15}$ Others argued that it was a rational entertainment, a much better pastime than gambling. ${ }^{16}$ Not that these were mutually exclusive; both Barrymore and Mrs Hobart were notorious for both gaming and playing. ${ }^{17}$ Richard Graves's thorough anatomization of the dangers of private theatricals gathers together criticisms frequently made of 'Theatrico-Mania'. ${ }^{18}$ For one thing, private theatricals were not really private: 'too many nobles give their rural retreat some resemblance of a public place; and collecting a croud [sic] of half-civilized savages from the surrounding neighbourhood, to see the raree-show and applaud their performances' (59). In regarding the lower orders in the rural fringes as racially as well as socially inferior, Graves exemplifies an attitude that Saree Makdisi identifies as characteristic of the Romantic period. ${ }^{19}$ Makdisi argues that during this period, England did not regard itself as homogenously Western and thus fully superior to the Oriental Other. Dibdin's impersonations of character types such as the Irishman and Cudjo the

13 Rosenfeld, Temples, 36-7.

14 The fencing master, Henry Angelo, claimed that 'during the time I was one of the dram. pers. at Brandenburgh-House, my sole motives were to have the means (tickets) to oblige others'. Reminiscences of Henry Angelo, 2 vols (London, 1828), 2:310.

15 Helen E. M. Brooks, "One Entire Nation of Actors and Actresses": Reconsidering the Relationship of Public and Private Theatricals', Nineteenth Century Theatre and Film 38/2 (2011): 3-6. For an assessment of the acting ability of aristocratic amateurs, see Rosenfeld, Temples, 167-9.

16 Angelo uses this term to describe the activities of the Pic Nic Society, perhaps borrowing the phrase from their own publicity (Reminiscences, 1:294-5).

17 On Barrymore, see Rosenfeld, Temples, 16-33; Angelo, Reminiscences; Anthony Pasquin [John Williams], The Life of the Late Earl of Barrymore (London, 1793); John R. Robinson, The Last Earls of Barrymore, 1769-1824 (London, 1894); Truth Opposed to Fiction, or, An Authentic and Impartial Review of the Life of the Late Earl of Barrymore by a Personal Observer (London, 1793). On Mrs Hobart's conviction and fine for running a faro table, see James Gillray, 'Modern-Hospitality, - or-A Friendly Party in High Life' (1792); 'The Loss of the Faro-Bank; or-The Rook's Pigeon'd' (1792); 'The Exaltation of Faro's Daughters' (1796); 'Discipline a la Kenyon' (1797).

18 Richard Graves, 'Theatrico-Mania: An Essay on the Rage for Private Theatrical Exhibitions', in Senilities; or, Solitary Amusements: In Prose and Verse: With a Cursory Disquisition on the Future Condition of the Sexes (London, 1801), 57-69. Fuller explorations of the risks they posed to propriety occur in three novels of 1814: Maria Edgeworth, Patronage; Frances Burney, The Wanderer; and Jane Austen, Mansfield Park.

19 Saree Makdisi, Making England Western: Occidentalism, Race, and Imperial Culture (Chicago: University of Chicago Press, 2014). 
Negro as well as his eccentric 'Oddities' and 'Wags' might constitute in Makdisi's terms part of the work of making England 'Western'.

Not only were theatricals the source of neighbourhood gossip, but columns headed 'Private Theatricals', 'Bon Ton', or 'Dilettante Theatricals' appeared in numerous London papers, and items were often picked up by the regional press. The desperation of amateurs to get a mention in the press is satirized in James Powell's Private Theatricals, a two-act farce published in 1791, but not performed. Worrall argues that Powell was a government spy, which might suggest that his play encodes a suspicion of theatricals as socially subversive. ${ }^{20}$ In the play, Lady Grubb, the theatre-mad wife of Alderman Grubb, instructs the gentleman actor Buskin to write up the following 'review' and send it to the newspapers: 'The tragedy of Romeo and Juliet, at the elegant Lady Grubbs['], last evening, was attended by the most numerous, and brilliant assemblage ever witness' $d$ at a thing of the kind; all the first nobility throng'd to see it, the confusion to procure seats, it is impossible to describe, numbers were obliged to return, her theatre being too small to contain so immence [sic] a crowd. ${ }^{21}$ It is highly likely that the dilettantes wrote or commissioned such puffs_ as did Dibdin himself when he repeatedly trailed the imminent opening of his Sans Souci in the autumn of $1791 .^{22}$

The main threat that Graves warns against is debauchery. Not only do modern plays not set a good example of morality; the theatre is itself a school for scandal:

As the green-rooms of our public theatres, were never reckoned schools of rigid virtue; so, I am afraid, the private apartments in noblemen's and gentlemen's houses, where the young people retire to change their dresses and the like, have been productive of more intrigue, and elopements, and improper marriages, to the distress of the families, and often, perhaps, the ruin of the thoughtless parties themselves. ${ }^{23}$

The fear of elopements fictionalized in Austen's Mansfield Park was instantiated in the relationship between the Rev. Edward Nares and Lady Charlotte Spencer, daughter of the fourth Duke of Marlborough, who fell in love while performing together at Blenheim Palace in 1789, though they did not marry till $1797 .{ }^{24}$ The Lord Chief Justice, Lloyd Kenyon, condemned the immoral tendency of theatricals in 1792, seizing the opportunity of a court case brought by the carpenter Reuben Cox against Barrymore for failing to pay him for work on his theatre: 'His Lordship doubted extremely whether they had ever inculcated one single virtuous sentiment.

20 Worrall, Theatric Revolution, 274-309.

21 James Powell, Private Theatricals, Act 2, Scene 2, in The Narcotic and Private Theatricals. Two Dramatic Pieces by James Powell of the Custom House (London, [1791]), 25-6.

22 The explanation of the term sans souci quoted above comes from one such puff.

23 Graves, 'Theatrico-Mania', 64-5.

${ }^{24}$ For a popular account of this affair, see Allan Ledger, A Spencer Love Affair: Eighteenth-Century Theatricals at Blenheim Palace and Beyond (Gloucester: Fonthill Media, 2014). Other elopements originating in private theatricals include that of Lady Susan Fox-Strangeways and the actor William O'Brien (1764), and Charlotte Wattell, who eloped with Thomas James Twiselton, second son of Lord Saye and Sele in 1788. They both ran away to play in the professional theatre. Mrs Twistelton became a professional actress, but her husband had a change of heart, divorced her, and became parson of Adelstrop. See Rosenfeld, Temples, 124, 128-32. 
He had known instances where they had the contrary effect; and they usually vitiated and debauched the morals of both sexes; the performers seldom retired from the entertainment, but every Romeo knew the estimate of his Juliet's virtue. ${ }^{25}$ Romeo and Juliet is the play selected for performance by the amorous young amateurs Villars and Lucy Grubb in Powell's Private Theatricals. They use it to dupe Alderman Grubb and his dilettante wife to facilitate their elopement. The Alderman is less concerned about his daughter's affair than his wife's extravagance and pretention. His middle-class values, though stereotyped, are represented as superior to the affectation of those whose heads have been turned by the glamour of performance.

Graves also complains that theatricals lead people to forget the parts allotted to them by 'the great Master of the drama of life' (67). This anxiety about role-playing is also an anxiety about class mobility. Alderman Grubb is furious to learn that his servants have become uppity and no longer know their place (Act 1, Scene 3). In fact, the craze for amateur performance extended to almost all classes, as it enabled groups usually caricatured or excluded from the professional stage for a variety of reasons to become performers. It was popular among the gentry and the middling sort, especially in family groups such as Henry Fielding's friends the Harrises in Salisbury, as well as the Burneys, the Austens, and the LeFanus and the Sheridans in Dublin, who all enjoyed putting on a show at home. Others performed in urban private theatres such as Mr Fector's in Dover, Well's Street in London, and Fishamble Street in Dublin. ${ }^{26}$ Moreover, not only did aristocrats such as Barrymore recruit their estate staff to fill the dramatis personae, but the middle and working classes also organized their own clubs and societies. These ranged from Free-and-Easies and Song-and-Supper Clubs, where members would recite poems and sing songs, to the Spouters who met in taverns and coffee shops to 'spout' or recite speeches from plays. ${ }^{27}$ In the early nineteenth century these clubs evolved into more regular private theatres whose members paid a subscription to entitle them to perform; ticket sales were supposed to go to charity. Even later, they morphed into the Victorian Music Hall. Amateur dramatics gave people a chance not merely to be represented, but to represent.

The appeal of theatricals for these classes was in many ways the same as it was for the aristocracy: conviviality and participation. Moreover, all classes in private theatres enjoyed a privilege denied the minor theatres: permission to perform spoken drama. The combination of the monopoly of the patent theatres and the censorship of new plays confined the illegitimate theatres to burlettas and other kinds of musical entertainment. However, for the lower classes, theatricals also held

25 Quoted in Rosenfeld, Temples, 31.

26 See Dobson, Shakespeare, 38-46; Paula Byrne, Jane Austen and the Theatre (London: Hambledon Continuum, 2002), 3-28; Francesca Saggini, Backstage in the Novel: Frances Burney and the Theatre Arts, trans. Laura Kopp (Charlottesville and London: University of Virginia Press, 2012), 231-2; Anna M. Fitzer, "Feeling and Sense Beyond All Seeming”: Private Lines, Public Relations and the Performances of the LeFanu Circle', Nineteenth-Century Theatre and Film 38/2 (2011): 26-37; Brooks, 'One Entire Nation'.

27 See David Worrall, The Politics of Romantic Theatricality, 1787-1832: The Road to the Stage (Basingstoke: Palgrave Macmillan, 2007), 42, 133. Worrall treats this subject extensively in this work and also in Theatric Revolution. See also Leslie Ritchie, 'The Spouters' Revenge: Apprentice Actors and the Imitation of London's Theatrical Celebrities', The Eighteenth Century 53 (2012): 41-71. 
out the promise of social advancement. Spouters' Clubs offered opportunities for apprentices to network with tradesmen who might provide employment. It gave them social skills and experience of public speaking that would also enhance their careers. Furthermore, for many, amateur theatricals were a stepping-stone to a career on the professional stage, leading to complaints that they were taking bread out of the mouths of professional actors. ${ }^{28}$

The quality of these performances was also a concern. A review of a performance of Richard III at Hoxton Town Hall in 1831 spluttered, 'Mr Green seems to know as much about Shakespeare as a monkey knows about philosophy. ${ }^{29}$ Such complaints about the rights of the lower orders to assert their aesthetic judgement sometimes masked a fear of social instability or even insubordination. During the Revolutionary years, groups meeting in taverns, coffee houses, and so on were always subject to suspicions of seditious intent. Yet, while the act of putting on a private performance might challenge authority as represented by the legitimate theatres and local magistrates, most of the plays performed were not themselves politically radical. ${ }^{30}$

\section{DIBDIN'S PRIVATE THEATRICALS}

The widespread popularity of private theatricals made them an appropriate choice, then, for the opening night of Dibdin's first Sans Souci. What, though, was the entertainment like? Did it celebrate or mock private theatricals? If the latter, did it make the same complaints as other critics? And did it share any features with elite or popular private theatricals? To answer the first question (what was it like?): Dibdin's entertainments were made up of a mixture of spoken prose, music performed on his specially adapted piano-organ, and songs whose words and music he composed himself. There is no printed text of the full entertainment, but there is evidence to piece together: the advertisement for the first performance in the Morning Post (shown in Figure 6.1); the music and lyrics of the songs which Dibdin printed and sold separately from his 'warehouse'; the recollections of those who witnessed his performances; Dibdin's detailed account of one of his earliest entertainments; and fragments of an autograph manuscript of the entertainment, which seem to be scraps of the text he used in performance and then prepared with a view to publication as a collection. ${ }^{31}$

28 See Worrall, Politics, 2, 42, 78, $133 . \quad 29$ Quoted ibid., 133.

30 The Morning Post (17 April 1802) professed to find aristocratic amateurs a threat to the natural order, objecting when Lord Cholmondeley played the flute at a Pic Nic performance that a peer should 'waste the breath that should be used in discussing our laws, to produce sounds from a piece of wood to tickle the ears of the tabbies!'

31 Morning Post (8 October 1791); Hogarth; O’Keeffe; Musical Tour; BL Add. MSS 30961, ff. 1-13, 40-6, 147. The MS volume is entitled FRAGMENTS of songs, entertainments, etc., with three leaves of his novel, 'Hannah Hewitt; or, The Female Crusoe.'It looks as if Dibdin gathered together MSS that he had actually used in his entertainments and hoped to publish them under the title The Feast of Reason. He supplied a preface for the collection, but did not succeed in editing them coherently as, although some fragments are cut and pasted (using sealing wax) onto sheets and then edited, there are many fugitive scraps. 


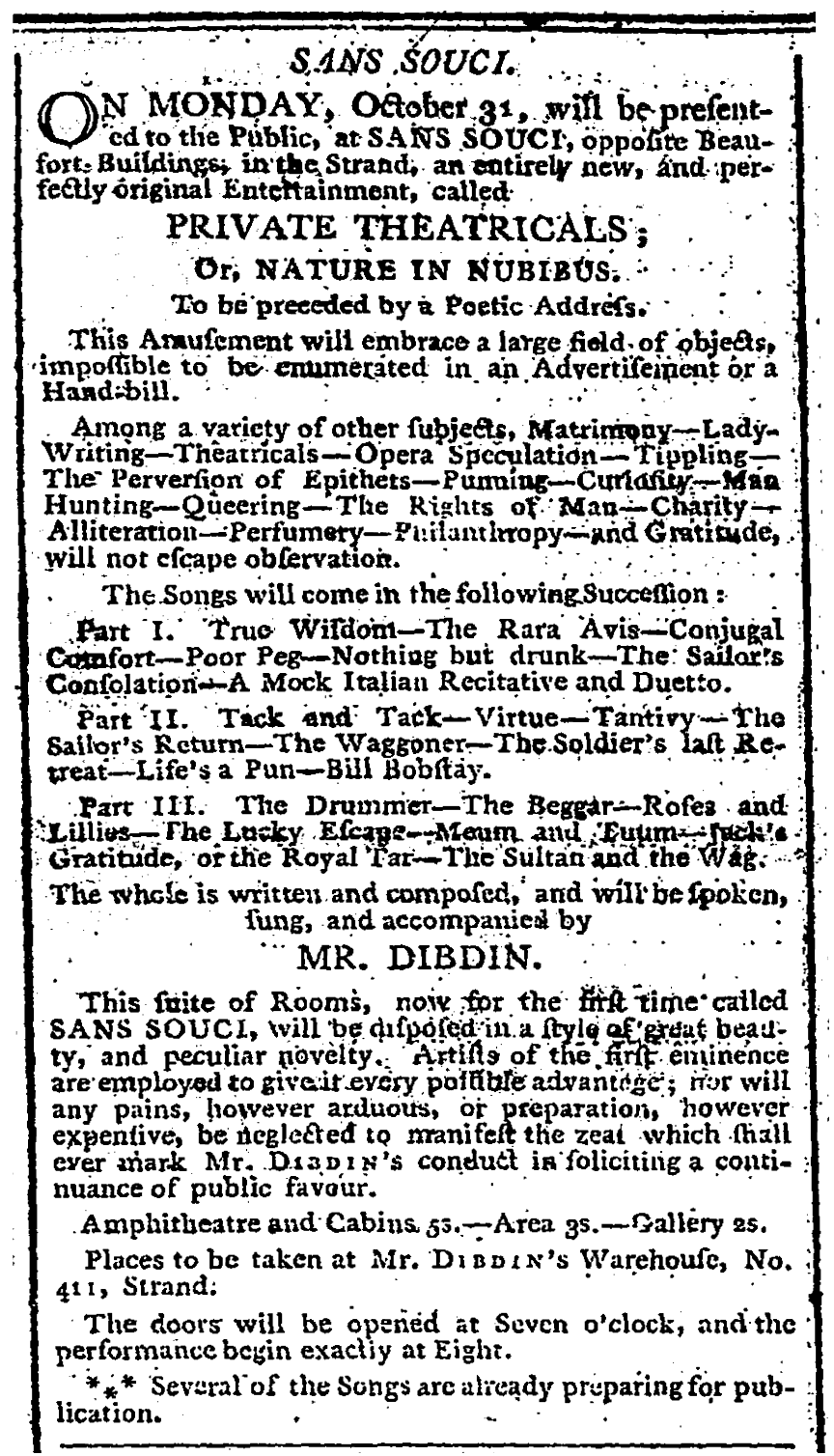

Figure 6.1. 'Sans Souci', Morning Post (8 October 1791). Advertisement. (C) The British Library Board.

Dibdin's manner of addressing his audience was distinctive, as was the production itself: as David Kennerley discusses in Chapter Five of this volume, he cultivated a particularly intimate performative persona. Being a one-man show, it was unlike most private theatrical performances, which usually imitated the bill of the legitimate theatres with a main piece and an afterpiece. The mixture of speech 
and song does, however, resemble the entertainments held in Song-and-Supper clubs as well as the 'Table Entertainments' pioneered by George Alexander Stevens. Yet the subject matter is so thoroughly miscellaneous, it is hard to see what direct bearing it has on the phenomenon of private theatricals. None of the songs refer to theatricals, whether private or otherwise. Many of them celebrate the big-hearted British sailor-the loyalist strain for which he became famous. ${ }^{32}$ One, 'Bill Bobstay', responds to a phrase that Tom Paine had just made notorious: 'The Rights of Man'. Other songs are less obviously topical or political, but most are sentimental about human variety and convey the message that we should be content with our lot in a way that is implicitly conservative. ${ }^{33}$ The second and third parts of Dibdin's entertainments had nothing to do with the title. Describing The Whims of a Moment, which he took on tour in 1788, Dibdin writes that after the interval, he would 'diversify my entertainment by running still further into eccentricity; adhering to no settled plan, but merely taking up detached subjects, ushered in only by a few explanatory words'. ${ }^{34}$ In other entertainments, Dibdin introduces his 'Wags', 'Oddities', and 'Quizzes': clubs of comical fellows including such eccentrics as Admiral Hawser, the Wild Irishman, a projector, a speculator, the Commodore, a dramatic pack, a levee hunter, and Sir Oliver Oddfish. ${ }^{35}$

Dibdin does, nonetheless, begin by directly addressing the subject of private theatricals. The set-up of the first part of the entertainment is a story about how Phoebus Apollo 'would often doze out his evenings in spight [sic] of the solicitations of the muses' (9r). The Muses have to find a way of keeping him amused, so they call in Momus, the god of satire, to assist them. He advises them to visit the earth to learn human manners, so that they can devise a private theatrical to wake Apollo from his torpor. He boasts, 'With a little of my assistance I have no doubt but you will get at men and manners very well; and really I don't see why Private Theatricals, in Nubibus, should not succeed as well as Private Theatricals upon earth, where between ourselves they are a little in the clouds too' $(9 \mathrm{v})$. When they return, the Muses each give an account of what they have witnessed. Each anecdote makes a witty or moral point about human manners. Momus congratulates them and promises that 'when I shall have touched up in quality of manager those hints you have already given and other which you will yet suggest, we shall be able to manage an entertainment worthy the attention of Appollo [sic]' (13r). While they were away, Momus recruited performers: 'The gods have consented to palm themselves upon Appollo as mortals and become the actors in your farce... What signify lord \& Lady players?-this is the place for

\footnotetext{
32 e.g. 'Tack and Tack', 'The Sailor's Return', and 'Jack's Gratitude, or The Royal Tar'.

33 On the subtlety of conservative culture in this period, see Kevin Gilmartin, Writing Against Revolution: Literary Conservatism in Britain, 1790-1832 (Cambridge: Cambridge University Press, 2007). 34 Musical Tour, Letter LXXXVII.

35 Charles Mathews developed a similar cast of characters for his monopolylogues. See Edward Ziter, 'Charles Mathews, Low Comedian, and the Intersections of Romantic ideology', in Tracy C. Davis and Peter Holland (eds), The Performing Century: Nineteenth-Century Theatre's History (Basingstoke: Palgrave Macmillan, 2007), 198-214.
} 
private theatricals, where the Muses ${ }^{\wedge}$ witty $^{\wedge}$ Momus manages and the Gods are all strollers' $(13 \mathrm{r}-\mathrm{v}) .{ }^{36}$

Does Dibdin employ this device in order to meditate deeply on the nature of private theatricals? Or even perhaps to satirize them in the terms we have already encountered? This metatheatrical framework has the potential for producing some interesting reflections on the phenomenon: Dibdin impersonates gods and muses imitating aristocrats imitating actors performing theatrical roles. We might dwell on the levels of unreality and elevation involved in elite private theatricals and consider them, in William Empson's terms, as a version of pastoral in which members of the court imagine themselves as their social inferiors (shepherds/actors) in order to attain a complex state of simplicity and refinement (Arcadian retirement/private play). ${ }^{37}$ Of course, one of the essential differences between private theatricals and the public theatre-as between Arcadian and actual shepherds-is that for the participants in one, it is mere play; for those in the other, it is work. This is not quite the point Dibdin makes when he has Momus opine that 'never were the words of their immortal poet that all the men and women are merely players more truly verified than at this moment' (9r). Indeed, he stops short of mounting a direct critique of private theatricals, preferring rather to jab at what he perceives to be derelictions of traditional gender roles.

The device does allow him to satirize humanity from the lofty perspective of the clouds. His chief concern here is gender. He maintains a constant battery against the Muses for their supposed feminine weaknesses: their pride (9r), their inability to manage without a male (9r, 13r), and their chattering (11r). Equally, however, he attacks transgressions of gender norms. His strongest criticism is reserved for women playwrights:

Formerly they spread their bewitching snares to captivate a husband Now they spread their witchery to captivate a thought, Gall, vitriol, copperas and gum mastick make up their the ingredients of their inky cauldron ... But it is not at all wonderful, for, as a lady writer the other day abused me, who is remarkable for the chastity of her epithets, this is the age of revolution, and england [sic] like every other part of the world is turning round on its own axle tree. (10r)

Women, he claims, have redirected their sorcery from courtship to histrionics because the Revolution is turning the world upside down. ${ }^{38}$ If he was thinking specifically about private theatricals, the Margravine of Ansbach would be the main target. She had written around eight pieces by 1791 and went on to write or adapt at least a dozen more. But Dibdin makes a similar complaint in Letter 36 of his Musical Tour about 'soi disant FEMALE SHAKESPEARES' (possibly he has Hannah Cowley or Elizabeth Inchbald in mind), so it is unlikely that he is thinking specifically about individual female amateurs. Meanwhile, men who

\footnotetext{
36 In a further draft of this entertainment, the gods descend to earth. Although this version is even more fragmentary, it is easier to tell how the anecdotes function as excuses for the introduction of the songs. (BL Add. MSS 30960, 40r-46v.)

37 William Empson, Some Versions of Pastoral (London: Chatto \& Windus, 1935).

38 He returns to the theme in the Private Theatricals scrap ff. $42 \mathrm{r}-43 \mathrm{r}$.
} 
engage in private theatricals are censured for failing to perform their proper roles: 'Athletic englishmen $[s i c]$ that nature intended for soldiers and sailors are now men milliners' (10r). This failure is more critical in these dangerous times as it leaves the country unprepared for war: 'the whitechappel manufactory has been at a stand some time' (10r).

Social status too is inverted by theatromania. Like Graves and Powell, Dibdin objects that the lower orders-women especially—have ideas above their station: 'Formerly they were all Nancies and Pollies and Sukeys and Dollys-Now they are all Cosmelias and Cornelias and Delias and Celias' (10r). While humans were taking on airs, the gods were descending to earth: Jupiter 'came on as an Irish man' (13v). English society is no longer stable; it has been turned on its axle tree by the revolution of private theatricals. The physical transformations wrought by transforming a home into a theatre are just as disruptive. In an anecdote that resembles the plot of Powell's farce Private Theatricals, Dibdin tells of a merchant who returns from a long voyage to find his warehouse transformed into a theatre: 'his bales of canvas were all cut into scenes his muslins and silks $\wedge^{\wedge}$ turned $^{\wedge}{ }^{\wedge}$ into Turkish habits and Harlequin Jackets' (147r). The merchant 'was distracted and yet I believe he would have borne it pretty well if his wife had not insisted on his playing Romeo' $(147 \mathrm{v})$. His only way to stop the theatricals and rescue his business is to behave as if he were in a public theatre, so he recruits some friends, '^ made $^{\wedge}$ a riot in the house $\wedge$ damned the play^ tore up the benches' $(147 \mathrm{v}$ ). Like Powell ('of the Custom House'), Dibdin's sympathies are with the down-to-earth merchant dealing in solid commodities, rather than with the performers who transform everything into the exotic and marvellous.

\section{A PRIVATE REVOLUTION}

To some extent, Dibdin did not satirize private theatricals more thoroughly or engage with them more deeply because the nature of his practice was mild satire on miscellaneous human oddities. As Kevin Gilmartin reminds us, loyalism does not preclude social criticism. ${ }^{39}$ Moreover, Private Theatricals was largely a vehicle for him to package up some of his old anecdotes and introduce new songs that he then sold individually. Yet there might be a specific reason and some larger motives for his soft-pedalling. The specific reason is that he might himself have been involved in theatricals. According to one source, he was 'one of the principal hands in the Wargrave Theatricals of 1790-91'. ${ }^{40}$ How Do You Do?, a short-lived periodical that Dibdin co-wrote with the actor and writer Francis Godolphin Waldron, carried sympathetic reviews of a private theatrical company which performed regularly in

39 See Gilmartin, Writing Against Revolution.

40 Highfill et al., A Biographical Dictionary, vol. 4. I have not found support for this claim in the standard sources on Barrymore, but 'Pasquin' (Williams) notes that Dibdin composed the overture for a new pantomime of Robinson Crusoe (attributed to Sheridan), which was performed at Wargrave in September 1790 (Earl of Barrymore, 19). 
Tottenham Court Road. ${ }^{41}$ The reviewer was evidently familiar with the amateur actors. More generally, there are affinities between his entertainments and the nature and culture of private theatricals. His one-man shows were billed as 'table entertainments'. The format implied a kind of domestic intimacy between performer and audience. Primarily, these billings were a ruse designed to evade the licensing laws. In 1747, Samuel Foote found a way of evading the Theatrical Licensing Act by inviting his 'friends' to drink a dish of tea or chocolate with him and then incidentally offering a theatrical performance. Henry Fielding followed suit. ${ }^{42}$ Yet they also attest to a blurring of boundaries between public and private and are part of a larger cultural experiment that opened up entertainment to a wider group of participants than professional actors at the patent theatres. The way Dibdin presented himself and his venue mingled the professional and the domestic in several respects.

His new theatre had some of the amenities of a genteel home: 'there will be two very elegant drawing-rooms', he purred in the press. ${ }^{43} \mathrm{His}$ stage resembled " "a vast and superb vestibule", with a perspective view of "a large and beautiful garden" behind it'. ${ }^{44}$ Admission to private theatricals was usually by invitation only; Dibdin treated his audience like invited guests, writing personal letters 'to the residences of those persons of distinction, whose warm and attentive solicitations have done Mr. DIBDIN so much honour'. However, he also had letters sent 'to every Lady and Gentleman of title or respectability with whose address he can possibly furnish himself' ${ }^{45}$ This is not a personal invitation but a mail-shot; he had to make a living. Nonetheless, as observed in Chapters Five and Seven of this volume, his manner was intimate. During the intervals, Dibdin would mingle with the audience and chat with his patrons. ${ }^{46}$

While satirizing private theatricals, Dibdin might also have learnt from them. Although they might not have conceived of their activities in this way, monopolyloguists, dilettanti, spouters, and miscellaneous entertainers in minor theatres were all pressing up against the legitimate theatre, challenging its cultural and financial dominance. Both the scant press coverage Dibdin's one-man shows received and the media storm that destroyed the dilettante theatricals organized

41 Dibdin and Waldron's How Do You Do? appeared fortnightly from July to November in 1796. Detailed reviews headed 'PRIVATE THEATRICALS, TOTTENHAM-COURT-ROAD' appeared in all but the first issue. The group, not to be confused with the Pic Nic Society, was headed by 'several gentlemen' who had raised a subscription to produce plays twice monthly on Thursday evenings. I am grateful to David Kennerley for drawing this to my attention.

42 Similarly, Mathews dubbed his shows 'At Homes'. See Ian Kelly, Mr Foote's Other Leg (London: Picador, 2012); Martin C. Battestin with Ruth R. Battestin, Henry Fielding: A Life (London: Routledge, 1989), 435; Richard L. Klepac, Mr Mathews at Home (London: Society for Theatre Research, 1979).

43 The World (27 September 1791).

44 General Magazine and Impartial Review (October 1791), quoted in Fahrner, 135. This publication shows an image of Dibdin on the stage.

45 The World (1 October 1791). 46 Fahrner, 122. 
in Tottenham Street by the Pic Nic Society were shaped by the opposition of the patent theatres to what they perceived as encroachments on their territory and challenges to both their cultural status and their box-office receipts. ${ }^{47}$ Though not politically radical, both Dibdin and the dilettanti set themselves against the theatrical establishment and participated in the revolution that eventually led to the overthrow of the monopoly of the patent theatres. ${ }^{48}$

47 The press campaign against the Pic Nic Society, probably orchestrated by Richard Brinsley Sheridan, harped on the threat that amateurs supposedly posed to the patent theatres. See, for example, The Morning Chronicle (26 February 1802); The Theatrical Repertory, or Weekly Rosciad, 26 (16 March 1802); The Times (17 March 1802). David Francis Taylor sees the source of Sheridan's opposition to the Pic Nics as partly professional and partly class-based. See his Theatres of Opposition: Empire, Revolution, and Richard Brinsley Sheridan (Oxford: Oxford University Press, 2012), 239-41.

48 See Moody, Illegitimate Theatre. Worrall describes 'the Government's role in enforcing regulation, monopoly and censorship' in Theatric Revolution, 18. Thomas Dibdin railed against the proliferation of London's minor theatres in his Reminiscences, 2 vols (London, 1837), 2:394-7. 


\title{
Interlude 2
}

\section{Dibdin and Jane Austen Musical Cultures of Gentry Women}

\author{
Nicola Pritchard-Pink
}

Singing was a vital accomplishment for young genteel women at the turn of the nineteenth century, and girls were expected to soothe wearied fathers and entertain family and friends through their musical performances. This injunction lies behind many of the collections of sheet music amassed by young gentry women from this period. Yet a closer inspection of these collections-and the musical library of Jane Austen in particular-reveals that this was far from the only reason why these young women collected and performed music. Austen 'was fond of music', practising every day, and 'in the evening she would sometimes sing, to her own accompaniment, some simple old songs'. ${ }^{1}$ Three of her personal songbooks survive, containing 151 pieces. $^{2}$ Of all the known composers of Austen's individually collected songs, Charles Dibdin is the most prominent. Austen owned at least eight Dibdin songs, including 'Bachelor's Hall', 'Poor Orra Tink of Yanko Dear', 'Sound Argument', 'The Joys of the Country', 'The Lamplighter', 'The Lucky Escape', 'The Soldier's Adieu', and 'The Woodman'. While, as we shall see, Dibdin's expectations for female domestic singing centred on the traditional values of femininity and moral instruction, Austen's song choices reveal a different approach. By examining these songs it is possible to glimpse Austen's use of her song collection as a means of interrogating and playfully reconfiguring contemporary ideologies surrounding feminine musical culture.

As well as being a prolific composer, Dibdin wrote several manuals on the subject of music. In The Musical Mentor, aimed at boarding-school girls, Dibdin combined musical theory with moral guidance in order to demonstrate how far a sweet

1 J. E. Austen-Leigh, A Memoir of Jane Austen, ed. Kathryn Sutherland (Oxford: Oxford University Press, 2002), 70.

2 Hampshire Record Office (HRO), 28A11/A3, A7-A8. In addition, over twenty songs are listed in Elisabeth M. Lockwood, 'Jane Austen and some Drawing-Room Music of her Time', Music \& Letters 15/2 (1934): 112-19. Together these represent only a proportion of Austen's total compilation of music, as 'a large collection of music by the most celebrated composers' was sold by auction when the family moved to Bath, as noted in the Reading Mercury and Oxford Gazette (4 May 1801). Moreover, female relations and friends would have shared their music collections with her, further extending her repertoire. 
accomplishment may strengthen us in our moral duties'. ${ }^{3}$ Both the educational text and the lyrics of the practice songs are heavily didactic, instructing girls 'to cherish the moral, ... to store the mind with ... instruction and amusement, ... and to be wiser, better, and more enlightened' when singing. ${ }^{4}$ Dibdin's highly gendered songs include 'A Portrait of Innocence', 'Constancy', and 'Vanity Reproved', demonstrating how he utilized song to dictate specific gender attributes. Perhaps partly in response to these cultural expectations, the majority of Austen's songs are on the appropriately feminine subjects of love and sentimentality. Religious music was also recommended as being particularly appropriate for young women, and Dibdin comments that 'the best music the world has produced is that which has been composed in honour of the Deity'. 5 This resonates with other conduct-book authors, such as James Fordyce, who recommended that women limit their song choices to those with 'elevated or virtuous' lyrics. ${ }^{6}$

Displays of feminine attributes such as modesty could also be exhibited through performance technique. Dibdin compares singing to reading aloud, encouraging girls to sing with tender expression, minimal artificiality, and 'truth and nature'. Through empathetic characterization, sweet simplicity, and an absence of affectation, young women could harness the power of song to command, and hence morally instruct, an audience, as Dibdin advises in his educational poem The Harmonic Preceptor:

Let them sing all that's natural, easy, and plain;

By expression, and feeling, the mind let them gain;

...

So shall singing the senses pervade and control;

And the influence of sound be received by the soul. ${ }^{8}$

On one level, Austen appears to have heeded such advice. When comparing her own voice to that of the famous soprano Miss Stephens, Austen noted that 'her merit in singing is I daresay very great; that she gave me no pleasure is no reflection upon her, nor I hope upon myself, being what Nature made me on that article'. An abhorrence of showy professionalism in preference to demure modesty in performance style added to the image of the feminine ideal.

And yet, simultaneous to these more conventional displays of femininity, additional identities were also being explored. We see this in Austen's personal collection, particularly in her choice of Dibdin songs, through which she could participate in and comment on wider narratives, far beyond what Dibdin and other conduct writers prescribed as suitable material for female performance. Indeed, although performed in a domestic setting, singing for the entertainment of family and friends should not be seen as a purely private activity and needs to be contextualized alongside other forms of domestic performance. As noted by Judith

3 Mentor, $51 . \quad 4$ Ibid., $31 . \quad 5$ Ibid., 48.

6 James Fordyce, Sermons to Young Women (Dublin, 1767), 189. $\quad 7$ Mentor, 47.

8 Charles Dibdin, The Harmonic Preceptor (London, 1804), 137.

9 Deirdre Le Faye, Jane Austen's Letters (4th edn, Oxford: Oxford University Press, 2011), 272. 
Hawley in Chapter Six of this volume, amateur theatricals were popular in Austen's family, and she inhabited her characters 'with great spirit'. ${ }^{10}$ By performing as different characters, young women could take part in a discursive form of role-play, experimenting with different identities. In this way, women could utilize singing to express individuality as well as engage with sexual, national, imperial, social, or political tropes.

Dibdin claimed that modern music was being saturated with the 'vilest trash', professing by contrast that 'in everything I have written, even in my comic songs, I have warmly inculcated morality'. ${ }^{11}$ Yet, as may be seen in the texts of Dibdin's comic songs held by Austen, he was far from prudish, often using bawdy humour to highlight social and sexual hypocrisy. In 'Lamplighter Dick' the singer takes on the role of the cheeky lamplighter who witnesses sordid sexual encounters:

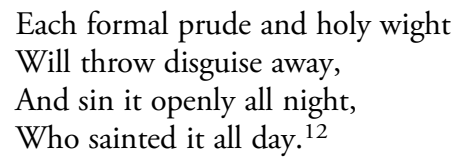

In a similar vein, 'Sound Argument' mocks the sexual inconstancy of women by first advising men to 'chuse a wife to whom truth and honour are given' but then conceding:

But honour and truth are so rare,

And horns, when they are cutting so tingle,

That, with all my respect to the fair,

I'd advise him to sigh and live single. ${ }^{13}$

While such comic sexual references were an integral part of Dibdin's aim to entertain as well as instruct his Sans Souci audiences, Austen's ownership of them demonstrates that women were certainly not excluded from this culture, despite Dibdin and others' recommendations that they should confine themselves to more chaste material.

The majority of Austen's songs, including those by Dibdin, are from a male perspective in first-person narrative, giving her freedom to express masculine characters. In 'Bachelor's Hall' Austen could sing of the boisterous adrenaline-fuelled male-only activity of hunting. As several of Austen's brothers hunted, being able imaginatively to participate in a completely different cultural narrative could have empowered her to share in, and comment on, a world ostensibly limited to men. By deliberately selecting songs that subvert gender expectations for her collection, Austen created opportunities to question contemporary notions of femininity, express a personal sense of humour, and actively inhabit alternative identities. ${ }^{14}$

10 Deirdre Le Faye, Jane Austen: A Family Record (2nd edn, Cambridge: Cambridge University Press, 2004), 164

11 Life, 3:42. 12 HRO, 28A11/A7. 13 Ibid.

14 Although it is possible that Austen collected such songs in order to accompany male relatives or friends, a nephew recalled that 'at Chawton she practiced daily, chiefly before breakfast. I believe 
Austen held many songs relating to the arduous yet noble life of sailors, including Dibdin's 'The Lucky Escape', which could reflect a similar attempt to engage in the lives of her brothers, two of whom were sailors. Austen rarely personalized lyrics, yet made an exception for Dibdin's 'The Soldier's Adieu', in which she struck through the word 'soldier' and replaced it with 'sailor'. ${ }^{15}$ By choosing to sing about brave sailors, Austen could actively participate in Dibdin's patriotism; as he noted: 'I have brought prominently forward those men whose valour has insured, and will perpetuate, the glory of their country'. ${ }^{16}$ Indeed, songs such as 'The Soldier's Adieu' revel in the duty, honour, and bravery of fighting men, celebrating a heroic life amid 'thundering cannons' and 'murdering carnage'. ${ }^{17}$ By singing in the character of such men, Austen could explore masculine and martial identities quite different to the stereotypical portraits of feminine subjectivity in songs recommended by conduct writers.

Alongside patriotism, vocal music could be used to facilitate women's participation in imperial narratives. 'Poor Orra Tink of Yanko Dear' requires the amateur singer to employ a strong dialect and impersonate a simple island native. Like Dibdin, Austen was talented in characterization, and by imitating poor Orra, Austen could have explored her place in Britain's expanding empire and participated in concepts of cultural hegemony. Such identities may have enabled her to feel renewed connections with family abroad and far away at sea.

Several of Austen's songs contain a strong element of political and social commentary, similar to the incisive, mocking humour of her novels. These include 'The Joys of the Country' and 'The Woodman' by Dibdin. Their lyrics offer a critique of modern society, a far cry from the limitations of 'virtuous' lyrics recommended by conduct-book writers. 'The Joys of the Country' provided Austen with a witty satire on the practicalities of country life, a subject she may have related to, living most of her life in the Hampshire countryside. Here the singer gently ridicules the picturesque ideal by noting for example:

How sweet in the dogdays

To take the fresh air,

When to save you expense

The dust powders your hair. ${ }^{18}$

Similarly, 'The Woodman' compares the simple purity of the trees felled by the woodcutter to their transformation into objects of vice and corruption:

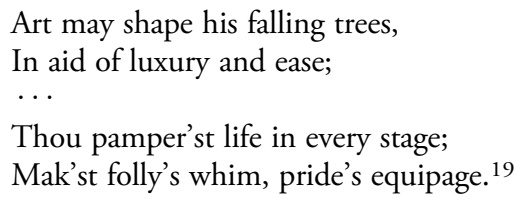

she did so partly that she might not disturb the rest of the party who were less fond of music.' Austen-Leigh, A Memoir of Jane Austen, 70.

15 HRO, 28A11/A3. $\quad 16$ Life, 3:42. 17 HRO, 28A11/A3. 18 Ibid.

19 The Vocal Encyclopedia (London, 1808), 130-1. 'The Woodman' is listed by Lockwood. 
By selecting such songs for her personal collection, Austen could have used music to articulate social and political commentary, providing an empowerment very different from Dibdin's expectations of female music-making.

Through exploring Austen's collection of Dibdin's songs we can see the clear discrepancies that existed between the contemporary cultural ideologies for women and the reality. By personalizing their music collections, women such as Austen could not only reflect an acceptable femininity but also broaden and interrogate it. In contrast to the advice of conduct books, Austen enjoyed many raucous, satirical, and political songs, while only one sacred song was present in her entire collection. ${ }^{20}$ Through song-collecting and singing, Austen utilized composers such as Dibdin to explore social and political matters while also expressing issues relevant to her sense of personal and familial identity. While detailed accounts of Austen's own musical performances are rare, the contents of her song collection nevertheless suggest both a keen participant in amateur music-making and an approach to song that strayed far beyond the rather narrow diet for young middle-class and gentry women recommended by conduct writers, and by Dibdin. Austen's choice of the Dibdin songs examined here could therefore be viewed as an expression of her humour, national pride, family relationships, and country lifestyle, as well as her place in the expanding empire and her role as a woman in society at large. Her song choices were no doubt influenced by factors such as age, geography, practical access to music, and the current musical tropes of her friends, family, community, and country. Yet, although Austen started singing in girlhood as a rite of passage, she chose to continue expanding her song collection throughout her lifetime, clearly demonstrating her sense of the positive value of personal expression through singing. 


\section{PART II}

\section{SONGS IN FOCUS}


Comp. by: Sivaperumal Stage : Revises1 ChapterID: 0003304483 Date:9/10/17 Ime:14:50:29 Filepath:d:/womat-filecopy/0003304483.3D

OUP UNCORRECTED PROOF - REVISES, 9/10/2017, SPi 


\title{
7 \\ 'True Courage' \\ A Song in History
}

\author{
Oskar Cox Jensen
}

Given the march of specialization across the nineteenth century, it is unsurprising that such a miscellaneous man as Dibdin was remembered for a statistically negligible portion of his output: the sea songs. For above a generation, Dibdin was a giant, thanks solely to these songs. Thus the European Magazine in June 1811, when he had finally retired: 'In the inferior branches of literature, the public are indebted to no living individual more than to Mr. Dibdin ... every one who sings his songs, or who hears them, gives and receives a lesson even in their mirth.' ${ }^{1}$ Eight years later, five after Dibdin's death, the reformer Francis Place wrote of the cultural changes since the 1790s, when the French Revolution prompted a deluge of reactionary propaganda: 'These loyal songs were succeeded by Dibdin[']s Sea Songs, and the old blackguard songs were in a few years unknown to the youths of the rising generation.'2 And in 1838 the composer William Gardiner reviewed the same period: 'A new order appeared of naval songs ... Dibdin, it is said, wrote more than a thousand. No other music was heard in public or private. They increased with our victories, but ... are now nearly forgotten.' 3 This volume moves beyond Dibdin's naval association— but it cannot be neglected entirely. These quotations provide a starting point, tying Dibdin's sea songs to a temporal context: England during the wars of 1793-1815.4 They focus attention on the songs' utilityinstructive, loyal, patriotic — whilst stressing their ubiquity. This cannot be explained by politics alone, as the question remains: why Dibdin? There were hundreds of loyalist songwriters, from anonymous artisans to William Cobbett and Hannah More. None had a fraction of Dibdin's success. If we understand his songs' place in English society, both during and after his lifetime, then we learn much about both the songs and the society.

1 Cited in Fahrner, 165.

2 Francis Place, Manners and Morals. BL, Add. MSS 27825, f. 144-5.

3 William Gardiner, Music and Friends: or, Pleasant Recollections of a Dilettante, 2 vols (London, 1838), $1: 227$.

4 Dibdin's impact in Wales and Scotland was negligible, and he was a pariah in Ireland: Fahrner, 154. 
I do not pretend, in a single chapter, to take a total view of these songs. Whilst the sea songs represent a minor fraction of Dibdin's work, they still numbered 'about ninety'; a comprehensive survey would sacrifice both depth and nuance. ${ }^{5}$ By following one song, I emulate this volume's broader approach: a single thread may guide us through a labyrinth of issues. In choosing 'True Courage' I have been led by two considerations. Firstly, its remarkable wealth of contextualizing material. Secondly, it is not 'Tom Bowling'. In order to do justice to this rare degree of presence-for a single song-in the broader historical narrative, I will structure sections of analysis around sequential stages in the song's history: its composition; its initial performances by Dibdin; its commercial dissemination; its appropriation as propaganda; its reception in that context; and its place in Dibdin's legacy. This is an approach designed to span intellectual disciplines as well as a century of history. Its chronology begins, not in the song itself, but in the ideological contexts of its conception $c .1798$.

\section{COMPOSITION}

'He was a melodist—not a musician.' 6 So wrote Edward Taylor, Gresham Professor of Music, in 1837. The comment sums up the judgement of the musical establishment during and after Dibdin's lifetime. As early as 1768, the Theatrical Register accused him of ruining his 'sometimes pleasing' melodies 'by setting instrumental accompaniments, that... are generally contrary to all the rules of harmonic composition'. ${ }^{7}$ Posterity too praised the tunes but belittled the arrangements, seizing upon Dibdin's scant training and his autodidact's approach to musical theory. ${ }^{8}$ In consequence, we approach his compositions expecting strong, simple melodies and crude accompaniments.

To subscribe to this verdict is to bypass the central ideological struggle of English music in the later eighteenth century. It was a debate heightened by the counterRevolutionary conflict—one in which national character, morality, and order were as much at stake as principles of composition. Rev. Dr John Aikin's famous essay on songwriting attacked 'the luxury of artificial harmony, taking place of the simple graces of melody'. ${ }^{9}$ For the composer William Jackson, discussing both vocal and instrumental music, 'Melody was in a barbarous state until the last hundred years. It long continued improving, but now seems, in this country at least, to be in a fair way of shortly losing it's $[$ sic $]$ existence.' ${ }^{10}$ Innovations were mere 'paltry shifts to conceal the want of Air'. ${ }^{11}$ The soul of music — melody—was under threat.

5 Life, 1:6. $\quad 6$ Taylor, f. $24 . \quad 7$ Fahrner, $28 . \quad{ }^{8}$ Life, 1:21-3.

9 John Aikin, Essays on Song-Writing. With a collection of such English songs as are most eminent for poetical merit (London, 1810), 9-10.

10 William Jackson, Observations on the Present State of Music in London (London, 1791), 10-11.

11 Ibid., 17. 
Loaded terms - 'luxury', 'barbarous'-suggest this was more than the eternal complaint levelled at innovation: that there are no decent tunes in jazz/punk/rap/ techno. These concerns were eloquently expressed in the writer Alexander Molleson's 1806 essay, 'Melody the Soul of Music'. ${ }^{12}$ Beginning with the verse 'Harmonic grandeurs choral joys impart, / But melody can move the feeling heart', Molleson views melody as analogous to conversation, a key tenet of British Enlightenment thinking. ${ }^{13} \mathrm{He}$ finds 'refined harmonic music' problematic, a 'mere chaos', both 'popish' and 'scientific'. ${ }^{14}$ The cardinal sin of modern harmony lies in making 'almost an entire separation between music and poetry. ${ }^{15}$ 'Simple and pathetic melody', by contrast, is closer to both speech and the 'voice of nature', and thus 'penetrates to the heart, and excites the corresponding affections'. ${ }^{16}$ In short, 'good music is favourable to virtue'. ${ }^{17}$

This was a potent argument in the context of ideological conflict with Revolutionary France, both in terms of melody's utility in uniting the people, and in its Burkean rejection of the metaphysics espoused by dangerous philosophes. A plain, unadorned melody was 'British', and a composition modulating through keys and experimenting with discords was 'foreign' (if not necessarily French). But 'simplicity' was intelligently theorized, and its pursuit could involve sensitivity and philosophical conviction.

It is clear from Dibdin's pedagogical writings that he shared a belief in simplicity, a sense that it was threatened by German innovation, and that he privileged the relationship between song and conversation. ${ }^{18}$ This was not xenophobia, as he took for his model the Italian school. ${ }^{19}$ Nor was it anti-intellectual. Rather, Dibdin associated complexity with a mechanical want of understanding: 'Superficial delight, afforded by flighty and extraneous pleasure, is to be dreaded... Begin not, therefore, with the finger, but the mind [or risk] a total ignorance of expression and sentiment. ${ }^{20}$ This was the rhetoric of taste as much as of the national idiom; Dibdin's reasoning appears as indebted to aesthetic theory as to a sense of the national. ${ }^{21}$ His conception of conversation and music as plain, sincere, and in some sense egalitarian was largely derived from Addison and Steele earlier in the century-yet the heightened political agitation of the 1790s redoubled the need to practise and protect these virtues. ${ }^{22}$ The same caution guided his empiricism: 'It is nonsense to talk of theory without practice... Theory is a chaos of science. It is the harmony in music ... to which habit, the child of certainty, must add melody

12 Alexander Molleson, Miscellanies in Prose and Verse (Glasgow, 1806), 47-137.

13 Ibid., esp. 54, 59. For conversation, see esp. Mee, Conversable Worlds.

14 Molleson, Miscellanies, 48, 63, 77. ${ }^{15}$ Ibid., 82. 16 Ibid., 47-8, 54.

17 Ibid., 66.

18 Mentor, 2-3, Charles Dibdin, A Letter on Musical Education (London, 1791), 23-4; Ibid., 16; Life, 1:xxiii-xxiv, 42.

19 Dibdin, A Letter, 23, 27-8. 20 Mentor, 32, 31.

21 An extension of this argument might pursue a parallel course to that in Denise Gigante, Taste: A Literary History (New Haven: Yale University Press, 2005). My thanks to Ian Newman for this suggestion.

22 Mee, Conversable Worlds, 6, 38, 40-3. Mee's reading of the poet William Cowper offers striking parallels to Dibdin. See ibid., 168-77. 
and lend beauty. It is a universal remedy that applies to nothing. ${ }^{23}$ Here is that Burkean scepticism in which the chaos of the scientific was given greater resonance by the chaos incarnate in the Parisian Terror. ${ }^{24}$

In discussing 'True Courage', then, we should appreciate the ideology beneath Dibdin's simplicity. The particular circumstances of its composition reinforce the link between song, sociability, and conversation. Taylor gives us Mary Ann Davenport's eye- and ear-witness account: 'I went to Ealing, where Mr. Dibdin then lived, to dine with him... Dibdin went into the garden, round which he continued to walk till dinner was announced. On entering the room he said "I have written a song since I left you," and after dinner he repeated it. The Song was "True Courage"'. ${ }^{25}$ The story seems implausible, yet it squares with Dibdin's general practice. He was exceptional, not only in the speed of his writing, but in being both composer and lyricist. 'The same impulse that inspired the words, has generally given birth to the music, and those that are the most celebrated, have been produced with the least trouble... I could mention, perhaps, thirty very prominent songs, that did not take in the writing and composing more than three quarters of an hour each. ${ }^{26}$ This set Dibdin apart: elite songs were written by setting an established poem to new music, and vernacular songs by the opposite process. What now seems obvious was then an exceptional position, at least within the context of loyalist songwriting: 'The music must be sorted to the mode of expression as well as the sentiment itself; and thus, there must be a kind of give and take accordance between the music and the words, which is indispensibly [sic] necessary to heighten the effect of both.' ${ }^{27}$ If 'True Courage' was written in the course of an evening's dining, then it speaks to Dibdin's rare talent for composing the complete song, and accords with his belief in song's simple, conversational affect. Its composition-by a walker in a garden, not a scholar on a stave-also explains its success when performed by unaccompanied street ballad-singers, and consequently it was bought to be sung at home by purchasers who had never seen, let alone played, a pianoforte.

Dibdin did, however, write a piano accompaniment—probably just for publication, as his common practice was to perform, as a street singer would, with only the lyrics before him. ${ }^{28}$ Assuming this accompaniment roughly corresponds to Dibdin's own playing - there is no reason to doubt it - then this gives us a blueprint for the song, self-published in 1798, with the first verse set and the subsequent three written beneath. To contrast with and complement the score, given in Example 7.1, a recording of the vocal is available to stream or download at http://soundcloud.com/napoleonandbritishsong/31-true-courage-342.

\footnotetext{
23 Observations, 1:223.

${ }^{24}$ For a synopsis of the Burkean position, see David Simpson, Romanticism, Nationalism, and the Revolt Against Theory (Chicago: Chicago University Press, 1993), 2-12, 19.

25 Taylor, ff.17-18. 26 Life, 3:6. 27 Ibid., 1:xxiv. 28 Observations, 1:138-9.
} 
Example 7.1. Charles Dibdin, 'True Courage, written \& composed by Mr. Dibdin, and Sung by him in his New Entertainment, called $A$ Tour to the Land's End. Pri.1s. London, Printed \& Sold by the Author, at his Music Warehouse, Leicester Place, Leicester Square.' London, 1798. The $\mathrm{C}$ in the bass for bar 10 is corrected to a $\mathrm{Bb}$ in later editions.
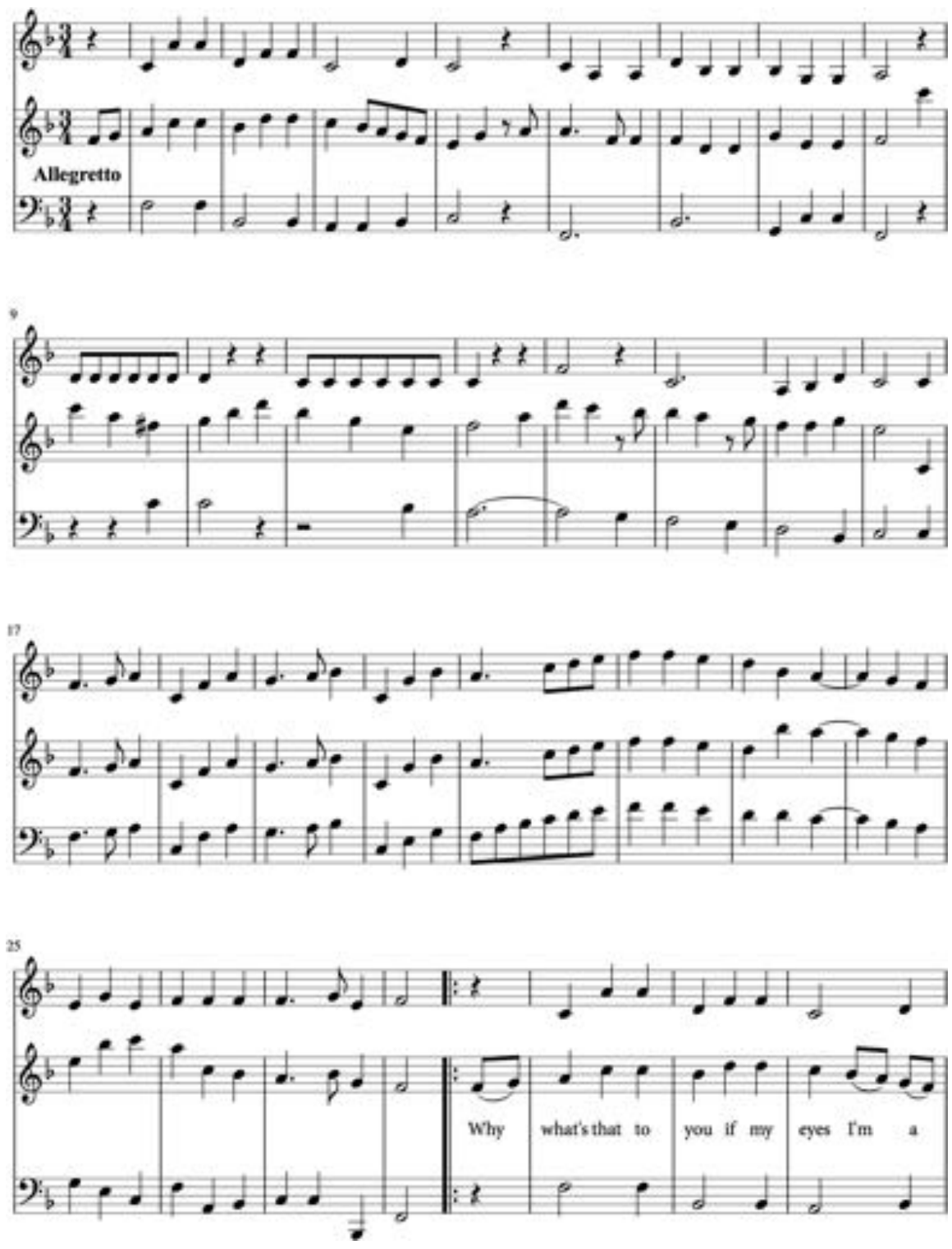
Example 7.1. Continued
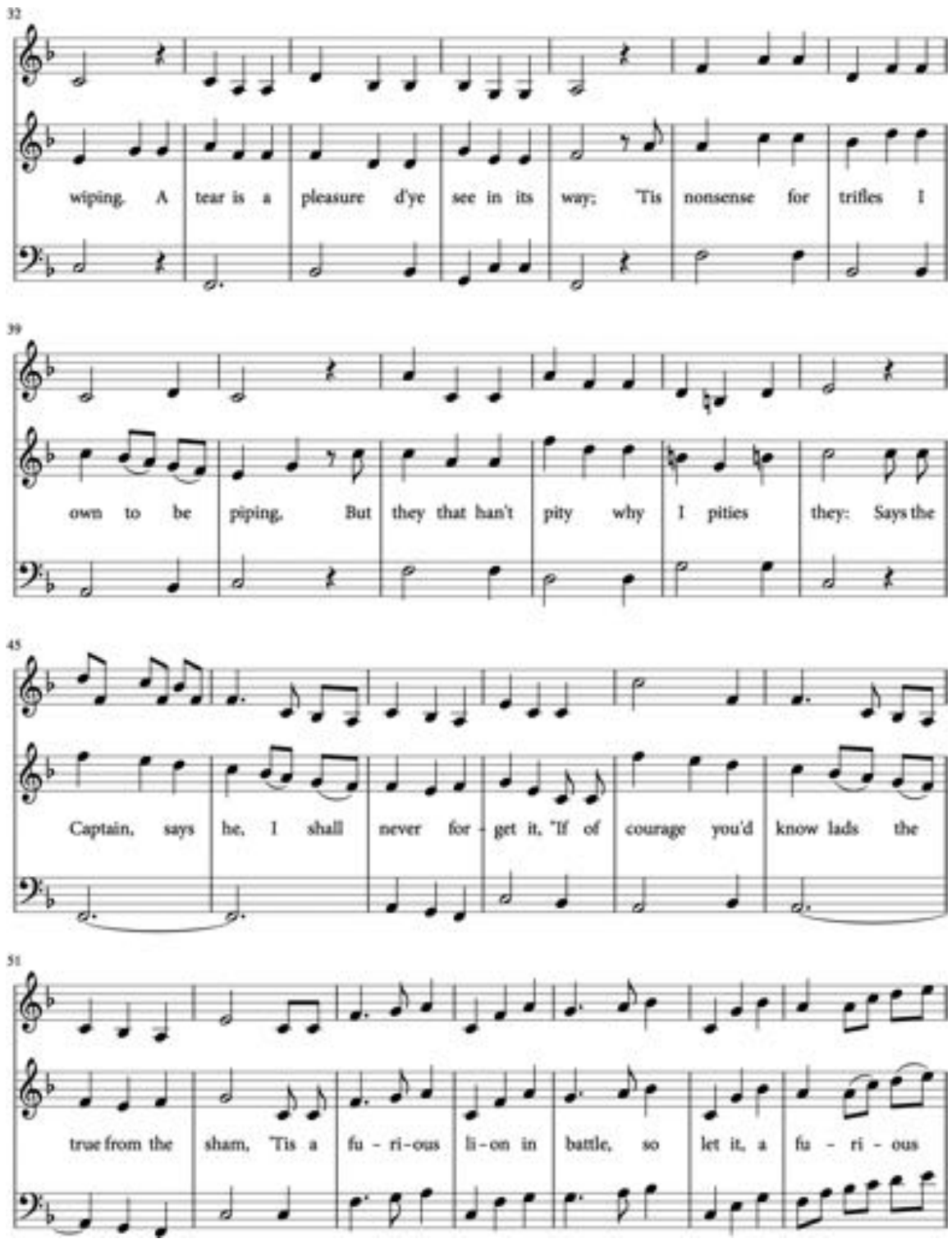
Example 7.1. Continued
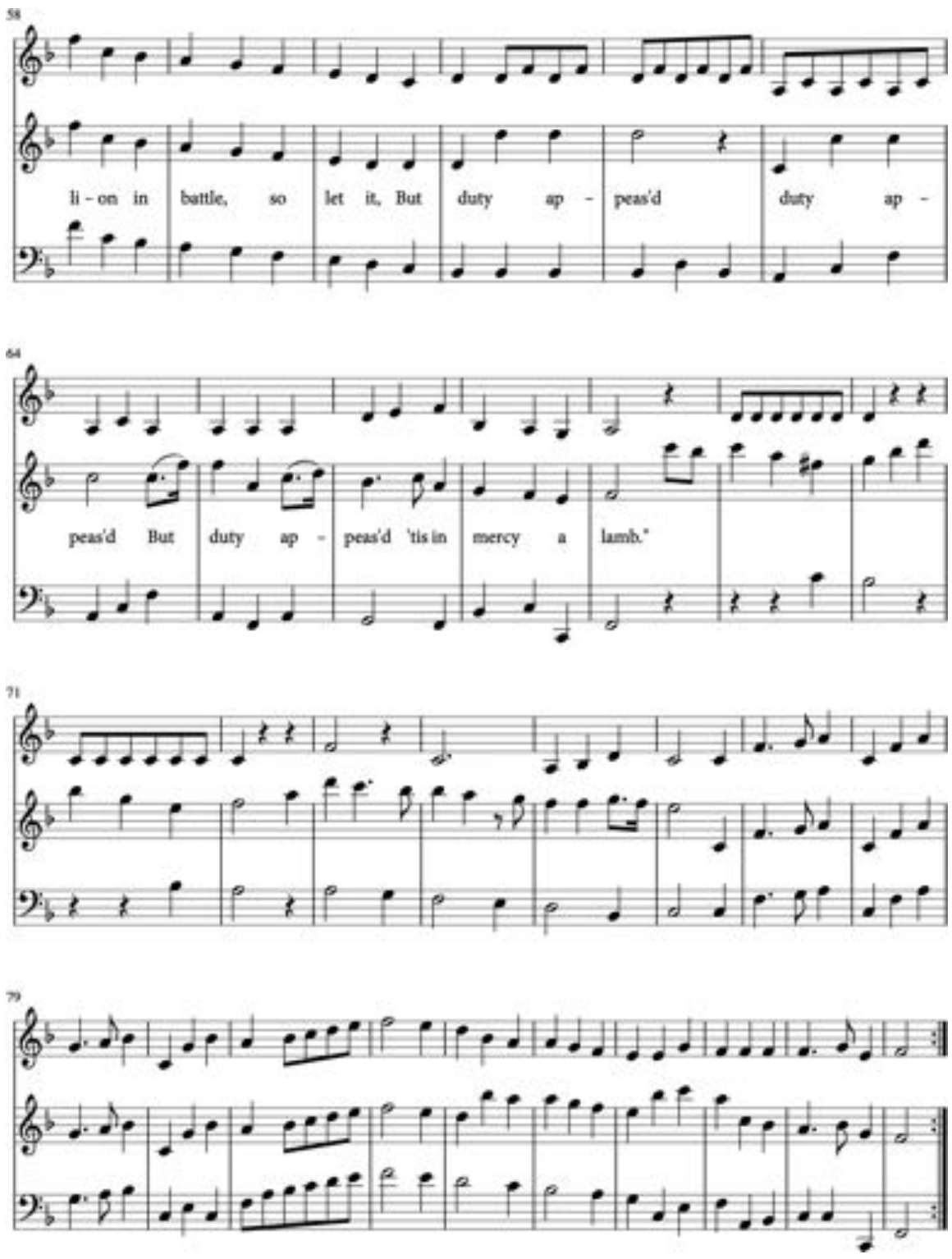


\section{Oskar Cox Jensen}

There was bustling Bob Bounce, for the old one not caring,

Helter skelter, to work, pelt away, cut and drive;

Swearing he, for his part, had no notion of sparing,

And as for a foe! - why he'd eat him alive.

But when that he found an old pris'ner he'd wounded,

That once sav'd his life, as near drowning he swam;

The lion was tam'd, and with pity confounded,

He cried over him just all as one as a lamb.

That my friend, Jack or Tom, I should rescue from danger,

Or lay my life down for each lad in the mess,

Is nothing at all;- - 'tis the poor wounded stranger;

And the poorer, the more I shall succour distress:

For however their duty bold tars may delight in,

And peril defy, as a bugbear, a flam;

Though the lion may feel surly pleasure in fighting,

He'll feel more by compassion, when turn'd to a lamb.

The heart and the eyes, you see, feel the same motion,

And if both shed their drops, 'tis all to the same end:

And thus 'tis that ev'ry tight lad of the ocean

Sheds his blood for his country, his tears for his friend.

If my maxim's disease, 'tis disease I shall die on,-

You may snigger and titter, I don't care a damn!

In me let the foe feel the paw of a lion,

But the battle once ended, the heart of a lamb.

In sum: four eight-line verses, set in a traditional strophic form, with line seven repeated once and the first phrase of line eight repeated twice prior to the final phrase. To some degree, this is a generic song. Yet there is some merit to positioning the song within Dibdin's conception of musical meaning. The exercise will be instructive in appreciating a song's musical implications in the contemporary imagination-even if some of its hearers, illiterate and unversed in tonality, would have been oblivious to Dibdin's intent.

Dibdin's fullest elaboration of musical meaning is in his Musical Mentor. Though written for young women, its strictures accord with his other works, whether addressed to fathers or written as dialogues for self-improving apprentices. ${ }^{29} \mathrm{He}$ invested meaning in the song's key (F major), time signature (3/4), and tempo (allegretto). F is the simplest 'flat' key-'a hearty character, and his music is solid and gratifying. ${ }^{30}$ For simplicity's sake, he allowed only two time signatures: 'Common time, which ... is an unruffled ocean', and that of 'True Courage': 'Triple time, which moves in threes, is the same ocean a little more agitated, with a ripple on the surface...I shall, therefore, call common time reason, and triple time pleasure.' Whilst pleasure was 'delightful', the risk of 3/4 was that in extremis, 'the heart is robbed of every thing rational, and pleasure is turned into frenzy'. ${ }^{31}$

\footnotetext{
29 Dibdin, A Letter, and Music Epitomized: A School Book (4th edn, London, 1811).

30 Mentor, 40.
} 
Though he avoided excess, Dibdin cautioned against the opposite danger regarding tempo: 'Allegretto is ... music played moderately quick. The great fault is playing and singing too slow; by which means singers particularly lose their spirit, and drawl out the words.' 32

'True Courage' stood at the bolder end of his spectrum: hearty, agitated, spirited, pleasurable. Its accompaniment is typical Dibdin, eschewing 'fashionable' arpeggios, preferring simply to mirror the vocal part in the right hand, generally a third below the melody, his favourite interval, with the bass completing the chord. ${ }^{33}$ 'One grand rule... is never to overload your accompanyment'; by simply following the melody, 'you relish the sense of the music with additional pleasure, and give your playing a ful[l]ness and grace which... I call playing with feeling and sentiment'. ${ }^{34}$ This was also pragmatic: Dibdin sold to as wide a market as possible, and a complex piano part could deter amateur purchasers.

Twice, however, Dibdin bends his rules by including 'improper' accidentals. ${ }^{35}$ The B naturals in bar forty-three heighten the dramatic effect at a critical lyrical juncture. This accidental, a sharpened fourth, is one of only two he excuses on grounds of 'beauty'. ${ }^{36}$ But in bar nine of the unusually extended introduction, the keynote itself is sharpened-common enough in contemporary instrumental music, but almost unknown in popular song. Here Dibdin breaks his own injunction against the 'exquisite pleasure' of such effects as 'extraneous and suppositious', considering it the composer's 'duty ... to keep them properly in check' ${ }^{37}$

This vocabulary-impropriety, duty-resonates with the song's lyric, a sentimental exhortation to compassion in warfare. Dibdin appreciated the sociopolitical importance of his songs; by stretching his own rules in 'True Courage' he risks purity for the sake of affect, needing to 'delight' if his message is to convince - and his song to sell. Much of this message inheres in the biblically allusive lion/lamb theme with which each verse ends. Dibdin recycles himself here: 'Jack Ratlin', from his 1784 comic opera Liberty Hall, featured the couplet 'In fight a lion:- - the battle ended / Meek as the bleating lamb he'd prove'. From 1798, however, the image became associated with 'True Courage', due largely to the complementarity of words and music. The seventh, 'lion' line is doubled, before attention focuses on the resolution on the tonic: 'lamb'. Organized in a conventional AABC form, the ' $\mathrm{C}$ ' section of bars 53-68, to which these lion/lamb lines are set, is striking. Its stop-start rhythms are insistently martial. Its vocal range is wider than the rest of the verse. The melody is remarkably, repeatedly angular, from the ascending steps of 'furious lion' to the octave intervals of 'duty appeas'd'. To contemporaries, this was unmistakably military music, a stirring rhetorical 'anchor' that gave way to the sweetness of the closing 'lamb', and the section of the song likeliest to lodge in the mind.

Elsewhere, the lyric displays Dibdin's lightness of touch in combining sentimentality with a sailor's vernacularisms ('You may snigger and titter, I don't care a damn!') and jargon ('pelt away, cut and drive'). Though no sailor, he endured gales

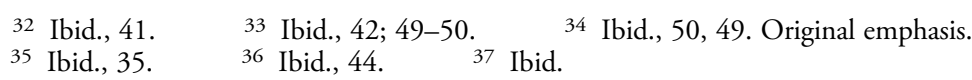


in the Bay of Biscay and two days' storm in the Channel, waters notorious for their hostility. ${ }^{38}$ Born in Southampton, he had early exposure to sailors' vocabulary which he took pains to refresh, befriending a smuggler in 1785 with the goal of 'mending my nautical knowledge'. 39 'True Courage', in all aspects, was the considered production of a consummate professional.

\section{PERFORMANCE}

For Dibdin, this professionalism was not synonymous with specialization; he was always the first performer of his solo songs. 'True Courage' was introduced on 6 October 1798, and premiered in London on Saturday 1 November in Dibdin's solo entertainment, $A$ Tour to the Land's End. ${ }^{40}$ To publicize his homecoming after an extensive tour, Dibdin advertised in the Morning Post, a popular daily sold for sixpence, on 31 October. The ticket prices - two to five shillingsindicate an affluent but not aristocratic audience. The venue was Dibdin's own theatre-though he was known to give supplementary daytime performances at the Paul's Head Assembly, a fashionable City watering-hole, at four shillings a ticket: Dibdin cultivated the aspirational middling sort. ${ }^{41}$ The aim was to be 'light, chatty, informal, and intimate', in a space where a nautical railing, raised platform, symmetrical candelabra, and exotic canopy focused attention upon the performer. ${ }^{42}$ A sketch of this space, included in the Pocket Magazine's guide to numerous venues, may be seen in Figure 7.1.

From this position, as Judith Hawley has noted in Chapter Six of this volume, Dibdin would engage in extemporary conversation with waggish auditors in the pit. This format drew the repeat custom of, for example, the bookseller Richard Ryan, as well as the antiquarian John Britton, who recalled, 'At this rational, amusing, and instructive school of song and music, I spent many pleasant evenings between $1796 \ldots$ and $1810 .{ }^{\prime 43}$

'True Courage' came third in the final 'part'. Top billing went to 'Nelson and Warren', a topical adaptation of his own 'Nelson and the Navy'. Like the other nineteen songs, 'True Courage' was preceded by a 'recitation', in this case on 'Compassion'. The song and recitation on either side were sequenced to provide a continual contrast: 'My business has been as much as possible to give an opposite effect to the songs, as they succeed each other ... I, therefore, leave the subject of a song gradually, get into extraneous matter, and then bring the audience into that state of temper which best inclines them to relish the song which is to follow. ${ }^{24}$ Here we see the miscellaneous Dibdin, child of the eighteenth century, fulfilling expectations of variety within the potentially monotonous one-man show, manipulating his audience in prose and leading them through the succession of moods so

\footnotetext{
38 Life, 2:272-4. 39 Observations, 1:170.

41 Hogarth, 1:84. 42 Fahrner, 123, 146.

40 Fahrner, 225, 149.

43 Ibid., 147.
} 


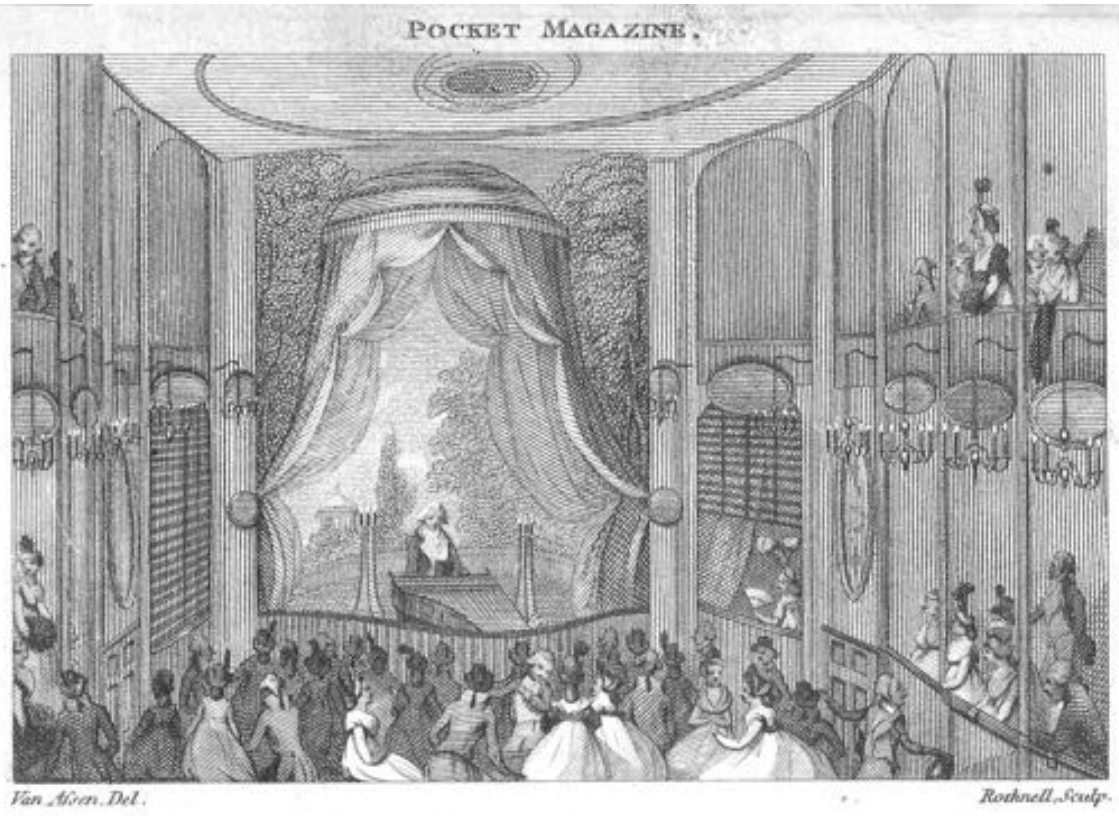

SANS - SOUCI.

Figure 7.1. Thomas Rothwell after Benedictus Antonio van Assen, 'Sans-Souci'. From Pocket Magazine (London, c.1796). Engraving. Courtesy of the Trustees of the British Museum.

integral to late-Georgian taste. ${ }^{45}$ This fragment from Dibdin's papers may resemble the recitation preceding 'True Courage':

These are the sentiments inspired by real valour... They know the awful ordeal they have to pass; and, though as soldiers they despise it, as men they feel it-nay fear itfear it for the dear peace of those connections on whose joy hangs their best delight[;] fear it lest premature fatality should stop the carreer $[$ sic $]$ of their glory by which they seek to deserve the name of soldier and subject. Fear it lest fortune should deprive them of the greatest and truest enjoyment a hero can experience to stay unnecessary carnage to preserve the life of a friend or to administer the balm of comfort to the misiries [sic] of a conquered foe... For this exalted enjoyment the brave well risk their lives[.] For where is there perfect goodness and transcendant magnamitity [sic] so gloriously blended as in his heart who with the sword of courage bears the shield of benevolence and extends the laurel to secure the olive[?] ${ }^{46}$

To a modern ear, this might sound pompous. Yet the actor John O'Keeffe, who saw a solo show in 1792, wrote only of 'a few lines of speaking' - a plain, intimate effect also attested by George Hogarth, who attended in his 'early youth', and Taylor,

45 Weber, The Great Transformation, esp. 13-18.

46 BL Add. MS 30967 Charles Dibdin: Fragments, f. 161. 
who saw $A$ Tour to the Land's End at Norwich in $1799 .{ }^{47}$ Britton's view-'rational, amusing, and instructive' - concurs. We should conceive of the experience as an enlightened exercise in improving, diverting conversation, closer to salon culture than the Victorian music hall.

In performing 'True Courage', this rational objective was advanced by Dibdin's 'peculiar mode of singing'. ${ }^{48}$ According to Hogarth, he would 'deliver his song without further reference to book or music. His voice was a barytone $[s i c]$... of no great power or compass, but of sweet and mellow quality. He sang with simplicity, without any attempt at ambitious ornament, but with a great deal of taste and expression; and, being a poet as well as a musician, he was particularly attentive to a clear and emphatic utterance of the words. ${ }^{\prime 9}$ William Kitchiner, a friend of Dibdin and more sycophantic than Hogarth, agreed: 'He had a remarkably distinct articulation; so that ... every word he uttered was easily intelligible; for he had that sensible idea about Vocal Music, that the true intention of it is, to render the Words more impressive.'50 Taylor states that, during A Tour, 'there was no attempt at what we call singing, Dibdin's first object being to make every word of his songs distinctly heard', adding that 'although I have heard his songs much better sung... I have never heard the same kind of effect produced by them as when he sung them himself' ${ }^{51}$ All, moreover, praised his piano playing.

We should not mistake this distinctive delivery for incompetence: Dibdin wrote eloquently on this topic, combining classical analogy, first principles, and scholarly precedent, stressing the importance of 'distinct articulation'. ${ }^{52}$ The crux, again, was the comparison to speech: 'I compare singing to reading aloud, in the exercise of which merely uttering of words will not do; their sense must be impressed on the mind of every hearer. The reader must possess ease, eloquence, and grace. ${ }^{.53}$ Performances of 'True Courage' typified Dibdin's ideal: to instruct by affect, and to affect by employing the natural arts of the good speaker. Coming at the end of the most talkative decade of a conversational century, it is small wonder that 'True Courage' struck home.

\section{DISSEMINATION}

In pursuing the means by which that 'striking home' extended beyond the audience of the Sans Souci, we must consider issues of both exploitation and innovationfor it is tempting to depict Dibdin, in some ways a traditionalist, in others suited to the 1790s, as also ahead of his time. As an autodidact singer-songwriter of vernacular lyrics simply delivered, he anticipates 1960s America. As a selfpublishing, self-financing entrepreneur breaking free of the corporate music industry, touring to promote new material, he prefigures artists of the digital era: '[As] I knew it was the business of the music-sellers to recommend their wares, in the

\footnotetext{
47 O'Keeffe, Recollections, 2:322. $\quad 48$ Ibid. $\quad 49$ Hogarth, 1:xx.

50 Kitchiner, $24 . \quad 51$ Taylor, f. 12. Original emphasis.

52 Mentor, 42, 45-8. $\quad 53$ Ibid., 47.
} 
country in preference to mine, so I should defeat in some measure their intentions, and greatly extend the circulation of those articles my catalogue contained, were I to perform my different entertainments, occasionally, and so let my songs speak their own recommendation. 54

By 1798, Dibdin was selling his songs individually, each comprising four pages of music and lyrics with a variation for two flutes thrown in, priced at a shillingsixpence cheaper than the London average. ${ }^{55}$ These were available directly from Dibdin on tour, or at his Music Warehouse in Leicester Place. In the case of 'True Courage', he subsequently sold the same impression via Bland and Weller at 23 Oxford Street; identical scores are extant from 1800 and $1814 .{ }^{56} \mathrm{He}$ was too experienced to sell its copyright, however; these editions were 'printed for the Author'. By these means, his profits vastly outstripped the paltry sums once paid him by publishers. ${ }^{57}$

To judge by its legacy, 'True Courage' sold well. Its wider dissemination, however, was by pirated editions sold as single halfpenny slips and in cheap chapbooks, accessible to the poorest labourer, chimney sweep, or scullery maid, sold by ballad-singers themselves scarcely distinguishable from beggars. Dibdin, who had played a female ballad-singer in an afterpiece of 1769, The Jubilee, acknowledged this trade. ${ }^{58}$ Discussing the value of the lyrics in The Professional Life, he took to 'reckoning the songs at a halfpenny a piece': 'With all these the streets have echoed, and barrel-organs and other mediums have proclaimed their popularity, totally without my participation. 59

By definition these publications were ephemeral, yet many extant copies of 'True Courage' survive. Table 7.1 lists twenty-three separate editions from different printers, approximately nine of which were published in Dibdin's lifetime in London, York, northern England, and Edinburgh. These were surprisingly accurate, although one Newcastle garland from 1805 censored 'damn', and only one of the very first, by London's John Davenport, credited Dibdin. ${ }^{60}$ These productions gave the lyrics only, usually without indicating lines to be repeated. This was standard practice; broadsides of traditional ballads with repeats, such as 'The White Cockade', also omitted these. ${ }^{61}$ The tune could only be learned by ear. In the mixed print/oral culture of the street ballad, the seller would sing until the purchaser had it by heart. With 'True Courage', the interest lies in how balladsingers, poor and musically illiterate, learned the tune. They may have employed an alternative air, but its distinctive rhythms make that unlikely. It is more likely that singers learned the tune from either Dibdin's performances or a private function. Street singers could save for a cheap gallery seat, or linger outside with an ear to the door. ${ }^{62}$ It is no coincidence that the cities where 'True Courage' appeared during Dibdin's lifetime were fixtures of his regional tours. And though ballad-singers did

\footnotetext{
54 Life, 4:117-18. 55 See esp. the British Library volume of scores G.381.

56 BL G.383 (12), R.M.13.e.8. (1). 57 Life, 3:40-1. 58 Fahrner, 31.

59 Life, 4:327 and 1:6. 60 BL 11606.aa.24 (48) is the censored copy.

61 e.g. Bod. Harding B.15(372b).

62 e.g. The Surprising History of a Ballad Singer (Falkirk, 1818), 14; John Thomas Smith, A Book for a Rainy Day (London, 1845), 137.
} 
OUP UNCORRECTED PROOF - REVISES, 9/10/2017, SPi

Table 7.1 Unauthorized extant editions of 'True Courage' in cheap print.

\begin{tabular}{llll}
\hline Date (range) & Printer, Location & Format & Source \\
\hline $1798-1822$ & J. Morren, Edinburgh & Chapbook & Harvard, Lane Catalogue 59:22 \\
1800 & Anon., London & Songster & Sky Lark \\
$1800-2$ & J. Davenport, London & Single slip & V\&A, S.1244-1986 \\
$1801-5$ & J. Evans, London & Chapbook & Bod. Curzon b.24 (99) \\
1802 & Ann Bell, Penrith & Chapbook & BL, 11606.aa.23 (13) \\
1802 & J. Jennings, London & Single slip & Google books \\
$1803-48$ & J. Kendrew, York & Broadside & Bod. Harding B.11 (3895) \\
1805 & Anon., Newcastle & Garland & BL, 11606.aa.24 (48) \\
$1810-31$ & J. Marshall, Newcastle & Garland & A Garland of New Songs \\
$1813-27$ & G. Angus, Newcastle & Chapbook & Newcastle UL, Robert White Collection 36:7 \\
1815 & J. Paxton, South Shields & Garland & BL, 11621.a.3 (15) \\
$1819-44$ & J. Pitts, London & Broadside & Bod. Harding B.11 (626) \\
$c .1820$ & W. F. Collard, Bristol & Broadside & Cambridge, Madden 1837 \\
$1820-24$ & R. Hook, Brighton & Single slip & R. Hook Catalogue of Songs \\
$1820-29$ & C. Pigott, London & Single slip & Bod. Harding B.16 (38b) \\
1835 & J. Ferraby, Hull & Single slip & BL, 74/1870.c.2 (165) \\
$c .1835$ & W. Tegg, London & Songster & Cyclopaedia of Popular Songs \\
$1838-59$ & Ryle \& Paul, London & Broadside & Cambridge, Madden/London \\
& & & Printers 5, no.596 \\
$c .1848$ & T. Goode, London & Songster & Model Song Book, vol. ii \\
$c .1850$ & T. Birt, London & Broadside & Birt Catalogues II, no.289 \\
$1863-85$ & H. P. Such, London & Broadside & H. P. Such's Catalogue of Songs, no.694 \\
1865 & S. O. Beeton, London & Songster & Beeton's Book of Songs \\
1868 & R. De Witt, New York & Songster & Paddle Your Own Canoe Songster \\
\hline & & &
\end{tabular}

not frequent drawing rooms, ephemeral printers of 'True Courage' such as John Marshall and John Pitts did, and may have taught the tune to their sellers. Indeed, the lead song in one garland containing 'True Courage' was 'A New Song, Sung in Character, at the Masquerade, at Brayton House, Cumberland'. ${ }^{63}$ The path from private performance to piracy could be short.

'True Courage', composed whilst walking in a garden with only the barest accompaniment, was - like most of Dibdin's songs - perfectly suited to appropriation by ballad-singers. Its phrases are regular; it coheres strongly and keeps to a single key. Its tempo, plain yet colourful language, and memorable melodic contours make it ideal for a lusty rendition on a busy street. Its evident popularity, attested by the number and continuity of editions across England, reminds us that social barriers were permeable: a cultural product of one milieu-here, the polite London stage - could be appropriated and enjoyed in a place as remote as Penrith, by persons as removed from polite society as beggars and farmhands. By hearing and singing 'True Courage', a celebration of the common sailor, these individuals were participating in constructing the nation by propagating a patriotic song-a nation thus more widely and indeed democratically defined than many loyalists 
would like. Whilst Dibdin did not profit directly, he viewed this wider impact as a moral imperative. ${ }^{64}$ However, the moral health of the nation and the financial health of Mr Dibdin were not always in perfect harmony.

\section{‘TRUE COURAGE’ AND JAMES PLUMPTRE}

The primary association of Dibdin's sea songs is with the loyalist movement, which aimed to persuade the British to unite against the French invaders. Closely allied to this was the moral reform movement. Dibdin's songs were seen as crucial to both. He encouraged this, writing that 'duty might assist inclination, and therefore as a prominent feature in my labours, I sung those heroes who are the natural bulwark of their country... I thought therefore the subject honourable, and commendable, and in some degree novel; especially as it would give an opportunity through public duty of expressing private affection.' 65 Though this secured Dibdin his reputation and an annual state pension of $£ 200$, it alienated much of his public, who were either averse to mixing politics and pleasure or not themselves loyalists, and his overtly patriotic performances cost him both money and audience. ${ }^{66}$ This despite the mildness of Dibdin's own politics. ${ }^{67} \mathrm{His}$ was an ambivalent relationship with France. He spent nearly two years there, absorbing its culture and philosophy. ${ }^{68} \mathrm{He}$ read Voltaire and Molière, loved the language, and called it the home of theatre and literature-but professed a 'rooted dislike' for the majority of the French. ${ }^{69}$ Yet of his thousand songs, very few feature the French as enemies. Just ten from 1793-1814 make pejorative remarks—they are 'fearful' or 'poor fools' ${ }^{70} \mathrm{His}$ patriotism was sentimental, introverted, and inclusive, focusing on the heroism of the ordinary British sailor.

'True Courage' is the epitome of this: Dibdin at his most demotic. In 1797, Britain was rocked by naval mutinies at Spithead and the Nore. Mutineers' petitions employed Dibdin's rhetoric in defence of their conduct, making particular use of the lion/lamb image from 1784's 'Jack Ratlin'. ${ }^{71}$ Dibdin's wilful revival of the metaphor the very next year must have been in part an effort to rehabilitate the reputation of the sailor, a controversial move that underlines the nuanced and individualistic nature of his patriotic writing. For though 'True Courage' was well received by other loyalists, it was not beyond reproach.

James Plumptre, Fellow of Clare Hall, Cambridge, and vicar of Hinxton, was a leading activist in the moral and loyalist movements. In 1803 he tried his hand at songwriting, employing Cambridge's Professor of Music Charles Hague to set his

\footnotetext{
64 Life, 1:xxi-xxiii and 3:42. $\quad 65$ Ibid., 1:xxii.

66 Ibid., 4:6-9; Charles Dibdin, Songs of the Late Charles Dibdin; with a Memoir (3rd edn, London, 1852), xxviii.

67 Life, 4:9. 68 Ibid., 1:154-210. 69 Ibid., 2:84-5, 1:207.

70 Cox Jensen, Napoleon, 57-8. 71 Land, War, Nationalism, and the British Sailor, 99.
} 
lyrics to music. ${ }^{72}$ When that failed, he turned to Dibdin, soliciting permission to use the latter's songs: 'I wrote to him, requesting to know which of his Songs were already become public property, and of those which were still his own, whether he had any objection to some being inserted in my collection; expressing a wish in some instances, to correct them. ${ }^{73}$ Unsurprisingly, Dibdin refused to give Plumptre free use of either the songs, or the words alone, 'saying, that wherever his songs were so introduced, they were piracies'. ${ }^{74}$ He merely sent Plumptre The Professional Life, whereupon the latter found there were 'an hundred and ten, out of the six hundred songs [therein], which, upon the whole, I highly approve'-though, from the 'fastidious' Plumptre, this was praise indeed. ${ }^{75}$ 'True Courage' was one of those 110, though even here Plumptre had objections: 'The Devil is called by the familiar term of ... the old one; which is making light of that which we should only think of with horror and detestation. In "True Courage," v.4. the Sailor says, "I don't care a $\mathrm{d}-\mathrm{m}$ !" which I would alter to ... "I don't mind your bam!" or banter. ${ }^{16} \mathrm{He}$ also remarks, 'The first verse of "True Courage" is so beautiful, I must quote it entire'and in so doing, errs in the very first line, omitting 'that' from 'Why what's that to you', ruining the rhythm. ${ }^{77}$

Ultimately, Plumptre succeeded in securing leave to use the songs. It appears that Dibdin, financially distressed, sensed the way the wind was blowing, and took advantage of any opportunity to refashion himself as a moral public servant, availing himself of the patronage and free publicity of reformers. ${ }^{78}$ Yet Dibdin was a very different writer to the likes of Plumptre, an over-scrupulous scholar with no sense of rhythm. In employing colloquialisms ('the old one') and profanities ('damn'), Dibdin displays the common touch that was central to his popularityand absent from the sermonizing productions of Plumptre and his peers, from Hannah More to Thomas Spence. As Dibdin remarked: 'A sermon and a song, even a comic song, may have the same drift, and produce the same effect. The song, written to please, may be so managed as to instruct; and the sermon, written professedly to instruct, will attract more attention if it be so managed as to please. ${ }^{179}$ Dibdin's songs were always 'written to please'. Unlike his amateur activist contemporaries, he never mistook the singer's stage or pitch for a pulpit.

\section{A SONG IN WARTIME}

Subsequent years proved Plumptre's initial instinct to be right: Dibdin's songs were indeed a powerful force in constructing a particular vision of the martial, moral nation. In 1808, a Rowlandson caricature of British sailors below decks featured

\footnotetext{
72 James Plumptre, A Collection of Songs, Moral, Sentimental, Instructive, and Amusing, 3 vols (New edn, London, 1824), 1:v.

73 Ibid., 1:lvii-lviii. $\quad 74$ Ibid., 1:lix. $\quad 75$ Ibid. $\quad 76$ Ibid., 1:lxiii-lxiv.

77 Ibid., 1:lxx.

78 Ibid., 3:v-vi, and idem, Letters to John Aikin, M.D. on his volume of Vocal Poetry (Cambridge and London, 1811), xxix-xxx, 7.

79 Life, 1:xxiii.
} 
one of Dibdin's creations: one of the three tars is called Jack Junk. ${ }^{80}$ By Jack's feet lies a well-worn broadside, its title just legible. It is 'True Courage', serving as shorthand for the patriotic tar fully ten years after its first publication. Memoirs, particularly of 1803 when fear of invasion peaked, reinforce this connection. For a songwriter who took pains to engineer a receptive audience, the pitch of anxiety, patriotism, and farce experienced in parts of the country was a perfect backdrop. The publisher Charles Knight recalls his schooldays with a Dibdinesque blend of the heroic and the comic: 'In the same bedroom with me slept a son of Charles Incledon. He had inherited the glorious voice of his father, and nightly he kept us awake with some of Dibdin's most stirring songs. One day the rumour came to us that the French had landed... Surely it was not time for lessons when all England was going forth to fight; so we boldly petitioned for a half-holiday.' 81 The memory of Dibdin's songs is thus incorporated in a playful patriotic narrative. This is echoed in the memoir of Mary Lisle, in 1803 the precocious eight-year-old daughter of a Gloucestershire rector.

The songs of the period added... to the enthusiasm of the people; they were thundered out over the dinner-table amidst the rattling of glasses and thumping of fists, they were whistled beside the hay-cart and harvest-wagon, and Dibdin made our vessels echo to the same patriotic and heroic sentiments. Who shall say that that was not true poetry which stirred the hearts of all classes so deeply? There was one song of Dibdin's called 'True Courage', which was for ever in our ears that summer. ${ }^{82}$

Lisle's account has social and spatial implications. 'True Courage' worked in a variety of communal and solitary situations: convivial, domestic, and rural; adult and juvenile; polite and popular. 'Cousin Charles hummed it over his books, and sang it in his rambles and idle moments, till our hearts throbbed beneath its influence. Will Wild whistled it in the stable, and Edward was perpetually shouting it out at the top of his voice.' Primarily the song is bold and stirring as Dibdin intended, an inspirational aid to work and recreation. Yet Lisle's own renditions are lullabies: 'Eleanor and Agnes sang it together in their own room, and I murmured it to my doll as I rocked her to sleep in my arms, or tried its narcotic qualities upon a mischievous restless kitten that I called my own.' Given the normative associations of her age and gender, this repurposing is understandable, utilizing the melody's sweet, relatively understated qualities_-yet it remains significant that young girls accessed and enjoyed such a martial song, even in a nursery context. ${ }^{83}$ Nor is it necessarily voiced, but hummed, whistled, murmured, and sung to an uncomprehending kitten: the lyrical sentiment may be implicit, but it is not essential to performance. Nor, significantly, is the song ever accompanied. This not only aided its dissemination by ballad-singers; it multiplied almost infinitely the possible spaces and occasions for domestic enjoyment.

80 Thomas Rowlandson, 'Nautical Politeness or British Sailors perusing the Dispatches from Cadiz' (etching and stipple, hand-coloured. London, 1808). British Museum 1948,0214.697.

81 Charles Knight, Passages of a Working Life During Half a Century, 3 vols (London, 1864), 1:58.

82 Mary Lisle, 'Long, Long Ago:' An Autobiography (London, 1856), 67-8.

83 See Nicola Pritchard-Pink, 'Dibdin and Jane Austen', Interlude Two of this volume. 
Lisle ends: 'The air and the words are now ringing in my brain, and I must quote them' - and she does so, admitting, 'I quote from memory, and I may therefore have transposed the verses, or altered a word or two.' ${ }^{84}$ She gives four 'verses'. These are actually verses one and two, each split in half: three and four are omitted. She is, however, near perfect in her transcription, merely substituting 'danger' for 'the old one'. It is unsurprising that, after fifty-three years, Lisle fails to recall the entirety of a long, strophic song. The length of ballads decreased across the period, partly due to the shortening of attention spans in the establishments that ultimately evolved into music halls, and partly due to a shift from strophic narratives to throughcomposed settings of a single subject. ${ }^{85}$ 'True Courage' was perfectly suited to the start of the century. It would not survive the next hundred years unaltered.

\section{AFTERLIVES}

In 1857, the antiquarian Charles Manby Smith included Dibdin among such luminaries as Shakespeare, Burns, and Byron in a list of literary greats still found among the ballad stock of London's Seven Dials. ${ }^{86}$ In 1894, the folk collector Sabine Baring-Gould, also discussing current broadsides, was surprised to discover that 'the Poet Laureate is unrepresented; even Dibdin finds but grudging admission' ${ }^{87}$ These observations, though they chart a decline towards 1900, indicate the enduring popular appeal and robust elite reputation of Dibdin's songs. Indeed, most ephemeral editions of 'True Courage' postdate Dibdin's death in 1814 (see Table 7.1). They demonstrate that the song not only endured into the 1860s; it spread. Though many stem from London (from whence they circulated widely), the song also went west, to Brighton, Bristol, even New York.

Aside from minor typographical errors and the occasional censoring of 'damn', these left 'True Courage' untouched. The same cannot be said of four posthumous scores. The first, produced by Kitchiner in 1823, is the most dutiful. ${ }^{88}$ The second, from Hogarth's 1842 compilation, was arranged by the composer Francis Lancelott. ${ }^{89}$ He follows Kitchiner's minor melodic amendments, also rewriting the final cadence in a manner that, whilst formally correct, is affectively irresolute in the resolution: see Example 7.2.

Lancelott's (re)arrangement begins with 'oompah-pah' chords reinforcing the song's nautical associations before moving to decorous arpeggios that would have proved too much for Dibdin. This 'True Courage' is a safe parlour song, seeking to

${ }^{84}$ Lisle, 'Long, Long Ago', 68.

85 Bertrand H. Bronson, The Ballad as Song (Berkeley and Los Angeles: University of California Press, 1969), 204; Anthony Bennett, 'Music in the Halls', in Jacky Bratton (ed.), Music Hall: Performance and Style (Milton Keynes: Open University Press, 1986), 1-22.

86 Charles Manby Smith, The Little World of London; or, Pictures in Little of London Life (London, 1857), 253.

87 Sabine Baring-Gould, Strange Survivals: Some Chapters in the History of Man (2nd edn, London, 1894), 218

88 Kitchiner, score no.93 (unpaginated). $\quad 89$ Hogarth, 2:202-4. 
Example 7.2. Charles Dibdin arr. Francis Lancelott, 'True Courage', bars 44-50, in Hogarth, vol. 2, 204.

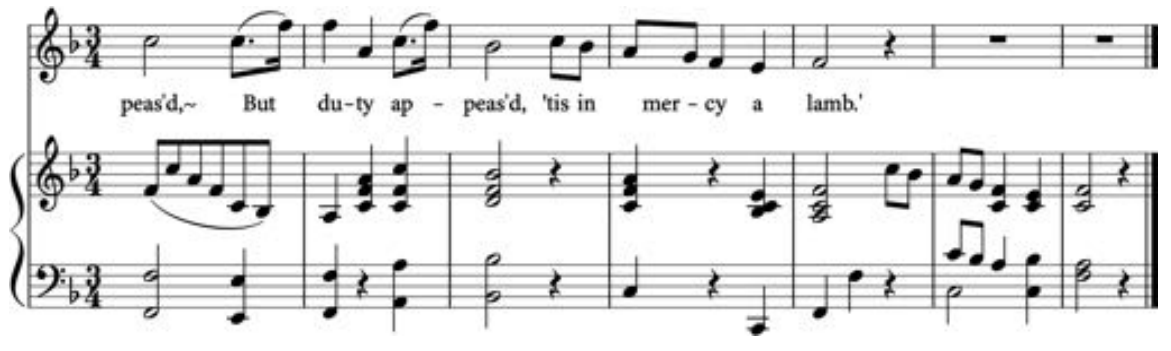

dress the plain ballad in civilized clothing. The next, from London in 1854, was 'Sung by Mr. Travers in his entertainment, entitled Nelson, the Life of a Sailor' ${ }^{90}$ Travers omits verses two and three in line with the trend for abridgement in the music-hall era. But in giving the tempo as Moderato, he commits what was for Dibdin a cardinal sin: playing too slowly. Travers alters 'I don't care a damn!' to 'I care not to sham!', a typically Victorian revision mirrored in the music. He follows Lancelott's changes, varies his harmonic intervals, and includes what Dibdin called 'improper' accidentals in the instrumental passages. The final edition comes from a collection priced for a mass market, published in London and New York in 1890. ${ }^{91}$ The arranger, Dr William Alexander Barrett (the ballad-collecting editor of the Musical Times) admits his editing: he had to update the style whilst selling the antiquity (Dibdin's dates are in the title). He works from Travers, moving from offbeat chords to arpeggios and giving the tempo as Moderato. Yet the complex arrangement, full of accidentals and elaborate chords, belongs to a new era. The pauses and leaps of Dibdin's melody are tamed by the accompaniment, incorporated into a sophisticated whole.

These scores highlight two points. Firstly, their cumulative nature places 'True Courage' in an active repertoire, rather than as a historical curiosity. Secondly, the ability of 'True Courage' to assimilate change demonstrates its inherent versatility, longevity, and attraction. The legacy of 'True Courage' mirrors Dibdin's own-its harmonic attributes the subject of condescension, its tune and lyric venerated. ${ }^{92}$ Accounts discuss it as performed, not as an abstract work. The anonymous J. R. wrote in 1828 of 'those heroes ... who have gone to battle, singing "True Courage"'. ${ }^{33}$ Henry Lee, a Somerset stage manager, spoke in 1830 of its influence, indicating by allusion that the lyrics had become common usage: 'I think the

90 BL H.2520 (11).

91 William Alexander Barrett (ed.), Twenty-One Songs Composed by Charles Dibdin. 1745-1814. (London and New York, [1890]), 36.

92 Kitchiner, 9-10, 26-9, Taylor, ff. 13-16, 20-24, Hogarth, 1:v-vi, xii-xxvi, and Henry G. Thorn, Charles Dibdin, one of Southampton's Sons (Southampton and London, 1888).

93 'J. R.', 'Monument to the late Charles Dibdin, Esq.', in The Crypt, or, Receptacle for Things Past 2 (1828): 286. 
character of an English sailor has been... greatly fashioned by the influence of Dibdin's songs. The sailor has been taught to think and to be ... "A Lion in battle, and afterwards a lamb!"'94 Also in 1830, a series of lithographs, Illustrations of Dibdin, were published by a firm specializing in devotional imagery. Only 'True Courage' survives, acquired by the British Museum in 1842 and reproduced here as Figure 7.2.

The lines paraphrased by Lee are printed below the image. The artists jettison Dibdin's vernacular overtones, producing a solemn composition so potently masculine that it now appears homoerotic. The massive bulk of the sailor owes a debt to the actor T. P. Cooke, equally celebrated for playing Jack Tars and Frankenstein's monster, whose representations heavily influenced polite perceptions of sailors. ${ }^{95} \mathrm{In}$ this image, later nautical melodrama demonstrates both its debt to Dibdin and its role in ensuring that 'True Courage' remained relevant.

Plainly, the song was not merely memorialized. The young Henry Russell-later famed for writing 'A Life on the Ocean Wave'-had an 1834 residency at the Sans Souci, where he was 'giving his audience all Dibdin's songs in succession. Russell is the most genuine and hearty singer of them-perhaps the best—since Incledon; and as we listened to the good old song of "True Courage" the other night, the little cabin of a theatre rung again with the manly tones of the singer, and the applauses of the audience. ${ }^{96}$ As this implies, Russell was not the only singer of Dibdin in the 1830s. Dibdin's illegitimate son Thomas asserts that the benefit concert of 1824, a public festival sponsored by 'Sailor Bill' himself, the Duke of Clarence (later William IV), featuring 'the most eminent vocalists of the day', conducted by Parry and accompanied by the same T. P. Cooke, was key to reviving his repertoire. ${ }^{97}$

Thomas's account is supplemented by an advertisement for Dibdin's scores, available from two leading firms, Novello and Purday. This commercial consideration accords with William Weber's Great Transformation of Musical Taste, in which musical nationalism in the 1830s, the success of indigenous vocal concerts from the 1830 s to the 1850 s, and the ballad concerts of the $1850-70$ s all provided a commercial platform for Dibdin, whose songs generally featured prominently towards the end of each programme. ${ }^{98}$ Yet his works flourished at a cost. Dibdin's self-fashioning in his later years in sympathy with the moral-loyalist campaigns meant that, in the context of increasing specificity and thematization of concert programming and musical thinking, his legacy was reduced purely to the sea songs, at the expense of the vast majority of his output. In concerts of the 1850-60s, 'True Courage' found a place primarily in programmes themed around the Navy. ${ }^{99}$

\footnotetext{
94 Henry Lee, Memoirs of a Manager; or, Life's Stage with New Scenery, 2 vols (Taunton, 1830), 2:12.

95 Louis James, 'Taking Melodrama Seriously: Theatre, and Nineteenth-Century Studies', History Workshop 3 (1977): 151-8.

96 Spectator 292 (1 Feb 1834): 9.

97 Thomas Dibdin, Songs of the Late Charles Dibdin: With a Memoir (2nd edn, London, 1841), xxxxxxii.

98 Weber, The Great Transformation, 72, 157-9, 276, 285-6.

99 'A Visit to the Victory', Morning Post 25195 (3 October 1854); 'Advertisement', Cheshire Observer and General Advertiser 48 (7 April 1855); 'Polytechnic Institution', Standard 11557 (26 August 1861)
} 


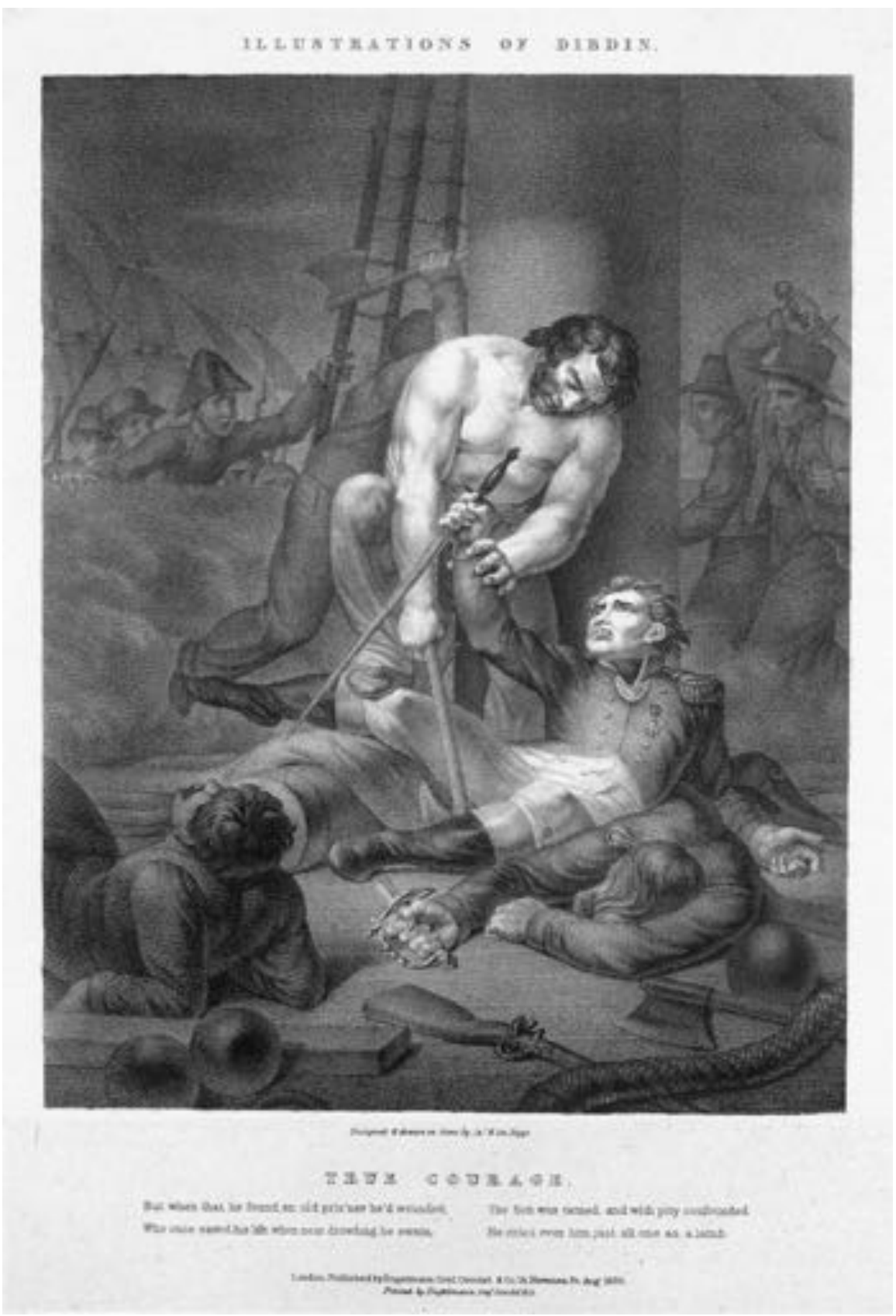

Figure 7.2. George and James Foggo, 'True Courage'. From Illustrations of Dibdin. London, 1830. Lithograph on chine collé. Courtesy of the Trustees of the British Museum. 
So dominant did this reductive association become that the author William Harvey, writing in 1862, mistakenly attributed to Dibdin the famous anthem 'Heart of Oak', written by William Boyce and David Garrick in 1760. ${ }^{100}$ The error is understandable, given that Thomas Dibdin included 'Heart of Oak' and other 'naval and national' songs in an addendum to an 1841 collection of his father's songs. ${ }^{101}$ So powerful was this naval theme that as late as 1900 , the noted musicologist and antiquary William Cummings lectured on the subject, stressing the songs' role in 'the re-manning of our navy at a critical period of our history'. So powerful was our song that Cummings ended his discourse by commenting, 'Some of [Dibdin's] songs, notably that entitled "True Courage", might well be revived.' ${ }^{102}$

100 'Aleph' [William Harvey], London Scenes and London People (London, 1863), 349.

101 Thomas Dibdin, Songs, Naval and National, of the late Charles Dibdin, with a Memoir and Addenda (London, 1841), 301.

102 The Musical Times 41/693 (1 November 1900): 748. 


\title{
8
}

\section{A Motley Assembly 'The Margate Hoy'}

\author{
Harriet Guest
}

Charles Dibdin's ballad 'A Voyage to Margate'—or 'The Margate Hoy', as it came to be known-formed part of his afterpiece, Christmas Gambols, first performed in December 1795 at his theatre the Sans Souci at 411 Strand, opposite Beaufort Buildings, and subsequently repeated after the theatre moved to Leicester Square in the summer of 1796. The song is of the kind categorized in the Oracle newspaper's review or puff-for despite the contempt Dibdin expressed for puffs, ${ }^{1}$ this has the look of one-as 'strong humour', contributing to the general object of the entertainment, which was 'broad farce; to which perversion of words, quaint misconceptions, and other modes of provoking a laugh, are surely fair'. ${ }^{2}$ It involves a cast of characters aboard a Margate hoy, one of the broad-bottomed barge-type sailing vessels that ferried goods and passengers between the City of London and the Thanet resort. The song's framing narrative takes the voice of Commodore Kelson (whose name exploits the convention of identifying sailors with parts of ships). He is introduced to the other passengers on the deck, and then comments with knowing amusement on their responses to the voyage, the humour of the watermen, and the seasickness and fear of drowning that seemed an almost inevitable part of the journey.

The stanzas of the ballad are interspersed with passages of spoken dialogue, a style Dibdin may have used during his musical tour of 1786 , when he performed what a hostile commentator identified as a 'whimsical farrago of recitation and music', ${ }^{3}$ but which he increasingly favoured in his later years as his voice deteriorated and he found that the arrangement played to the strengths of his performance style. As Judith Hawley and Oskar Cox Jensen discuss in Chapters Six and Seven of this volume, Dibdin used the confined spaces of the Sans Souci theatres to address his audiences with an animation and informality that must have added to the sense of participating in something like a parlour-room entertainment, and that style would have been enhanced by fluent and rapid movement between different modes of articulation.

1 See David Kennerley's discussion in Chapter Five of this volume.

2 Oracle (28 December 1795).

3 Benjamin Crosby, Crosby's Pocket Companion to the Playhouses. Being the Lives of All the Principal London Performers (London, 1796), 5. Dibdin also recited his own poetry during performances. 


\title{
THE WORLD AS A SOCIAL SYSTEM
}

In 'The Margate Hoy', the first stanza lends substance to the nautical character of the commodore:

\author{
Standing one Summer's day on Tower slip, \\ Careless how I my time should em-ploy, \\ It popp'd in my head that I'd take a trip \\ A-board of a Margate Hoy; \\ I took a few slops, such as shirts and a coat, \\ For of prog I knew well they'd be stor'd, \\ Then I hail'd a pair of oars shov'd off my boat \\ And a-way I dash'd a-board ... ${ }^{4}$
}

Talk of 'slops' and 'prog'-mariners' terms for clothes and provisions-is not opaque, but is colourful enough to flesh out his professional identity. A spoken interlude follows, in which the commodore and his acquaintance, Mrs Garbage the alderman's wife, hail one another by name, and she then introduces him to the other passengers on the deck.

'What, Mrs. Garbage! How is the Alderman?' 'There is my husband, Sir,' 'Pon my word and dicky I declare.' 'Give me leave, Commodore, to introduce you to my friends: Mr. Shadrack, Commodore Kelson, Commodore Kelson, Mr Shadrack.' 'Very much at your sharvice, Sir.' (Interlude 1)

As Kelson rather laboriously exchanges names with each character in turn, I imagine that Dibdin would have displayed his skills as a character actor, perhaps adjusting his costume and modulating his voice and accent to suit the different parts. He might have added some improvised dialogue to embellish satirical portraits of their distinctive gestures and tones in the style that is more explicitly indicated in his later song on 'The Masquerade', where directions call for 'Conversation among the characters', and later 'Confused conversation among the characters'. ${ }^{5}$ He would probably do the parts in different voices, like an early music-hall turn sharing a well-worn joke with an audience for whom familiarity - in several senses_-provided a comfortable sense of inclusion and intimacy. The interlude marks a distinct departure from the 'recitation' used to introduce the song, in which a bucolic character identified as 'an old blunt squire' repeatedly exchanges the 'compliments of the season', and comically laments that 'for Christmas cheer they make you eat nine meals and drench you with liquor enough to scald a pig'. We can readily imagine that the transition to the modern mix of city types aboard the hoy would have played to Dibdin's strengths as a character actor. ${ }^{6}$

4 Kitchiner, no.59, 'The Margate Hoy', verse 1 (all further refs in text).

5 'The Masquerade,' in [Charles Dibdin] Songs, \&oc. In New Years Gifts. A New Entertainment of Sans Souci. Written, Composed, Spoken, Sung, and Accompanied By Mr Dibdin (London: printed for the Author, 1802?), Part 3, 59-61.

6 BL Add. MS 30960: Table Entertainments vol. 1, In 'Christmas Gambol' section, reverse of f. 76. 
The Margate hoy provided rich possibilities for Dibdin to nurture the fascination with human diversity of which he writes in the preface to his 1803 account of The Professional Life. Representing himself as a prototypical subject, he claims, 'The world, as social system, I never could comprehend. It always exhibited to my view a monstrous and unfathomable gulph $[s i c]$, filled with contradictory and heterogeneous materials, in which the various passions and desires are hurled about at random; restless, errant, and disjointed.' In words incongruously reminiscent of Wollstonecraft's Vindication (1792) or Hays's Emma Courtney (1796), he portrays mankind as trapped by the futile excess of its own desires in a system where 'every thing is pursued, nothing attained', and 'All have their particular pursuits, yet all are lost in the multitude; everything appears the same, yet every thing varies. ${ }^{7}$ Margate might be said to afford a microcosm of this view. The town had developed since mid-century into the favoured resort for Londoners in search of health or a pleasurable break from city life. Available to those further down the social scale than the courtiers and professional elites who frequented Brighton or Weymouth, it offered the less-wealthy polite, the would-be fashionable, and the fashionable but disreputable the chance to restore their finances while enjoying the social life of the resort over the summer, and provided City dignitaries with a stage for the conspicuous display of their wealth. Most distinctively, it gave tradespeople the opportunity to taste with their families the leisure and high style they more habitually supported in the lives of their customers. It was not expensive to travel to Margate from London on the hoy, and concerned philanthropists sent some of London's sick poor to recuperate there, using the facilities of the Sea Bathing Hospital after it opened in 1791.

The perception of modernity as blurring social distinctions, differences becoming lost in the multitude where everything appears the same, which is so frequently commented on as a source of anxiety in the second half of the eighteenth century, found a focus in Margate, where commentators repeatedly noted, often with some amusement, that tradesmen could not be distinguished from the aristocrats they were supposed to serve, and fine ladies might be mistaken for fishwives. John Wolcot, writing under his pseudonym Peter Pindar, observed mockingly that, were the hoy to fail in its voyage to Margate:

Great were the loss of gentlefolks from Wapping,

Who, fond of travel, unto Margate roam,

To gain that consequence they want at home.

At Margate, how like Quality they strut!

Nothing is good enough to greet their jaws;

Yet, when at Home, are often forced, god wot,

To suck, like Bears, a dinner from their paws:- 8

7 Life, 1:x. For further discussion of the passages from Hays and Wollstonecraft that I mention, see Harriet Guest, Small Change: Women, Learning, Patriotism, 1750-1810 (Chicago: Chicago University Press, 2000), Chapter Twelve and especially 296-301.

8 John Wolcot [Peter Pindar], 'Ode to a Margate Hoy' [1792], in The Works of Peter Pindar, Esq., 5 vols (New edn, London, 1812), 3:64. 
Dibdin, in his two volume Tour through almost the whole of England (1800-2), narrates a version of the tale so frequently attached to the resort, observing that the 'most curious' characteristic of the place is the 'motley assembly' it attracts, and commenting on the resulting confusion of social differences which means that the shopkeeper who uses obsequious and 'insinuating manners' to cheat the aristocrat in Town here dashes past him whispering that 'it is a shame for such fellows to look honest tradesmen in the face, when they are so deep in their books'. ${ }^{9}$ Dibdin asserts that the Margate hoy is the site for the 'most curious instance of this equalizing system', for though the trip at its best was no more than an eight-hour 'jaunt in a pleasant yacht', it could in bad weather involve three days of confinement, in which 'high, low, rich, poor, sick and sound are all huddled together without discrimination', all encountering 'the great variety of peculiarly revolting circumstances which must inevitably attend the dispositions, the tempers, and the necessities of such a motley crew, so jumbled into all those chances of distress and inconvenience which from that situation alone could possibly arise'. ${ }^{10}$

In the Tour, the narrator focuses his sympathy and concern on the threat to polite sensibilities that the experience of Margate sociability on land and communal sickness on the hoy must pose, which is an indication of the readership he intends for his 'two large and handsome quarto volumes, embellished with forty views and twenty vignettes. ${ }^{11}$ But in his song the shared ordeal of the hoy is a source of humour, as the sickness and terrors of the passengers, pleading for the ship to be stopped or for someone to throw them overboard, are ridiculed across four stanzas of song and two spoken interludes. As the hoy rounds the Nore, where the waters of the Thames roughly collide with the currents of the North Sea, the singer callously observes:

And now 't would have made a philosopher grin

To have seen such a concourse of muns;

Sick as death, wet as muck, from the heel to the chin,

For it came on to blow great guns:

Spoilt cloaths, and provisions, now clogged up the way,

In a dreary and boisterous night;

While apparently dead every passenger lay

With the sickness, but more with the fright.

'Oh, Oh, I wish I was at home in my bed!' 'Oh, that I was a hundred miles off!' Marshey upon my shins!' 'Oh, Oh, will no-body throw me overboard!' 'Avast there.' 'Ah my poor dear pattern cap's blown into the pond!' 'Oh my soul, what a devil of a sickness!' 'Arrah, stop the Ship-Sir, would you be so kind as to be after handing me the caudle cup?' (Stanza and Interlude Four)

The interlude here again provides the singer with the opportunity to display the facility with which he mimics accents and adopts different personas. But admiration for his talents perhaps also made it possible for his audiences to relish the diversity of the hoy's passengers, as they are united and mocked in their physical

9 Observations, 1:34. 10 Ibid., 1:34-5. 11 Ibid., 1:Advertisement. 
vulnerability. For it seems likely to have been the capacity of the song to represent the characteristic heterogeneity of the modern metropolis that led to its inclusion in the collection Dibdin's son Thomas assembled under the patriotic title of Songs Naval and National (1841).

\section{CHARACTERS OF MARGATE}

When Dibdin first advertised the 'original and novel Amusement, called, CHRISTMAS GAMBOLS', he had represented it, in a departure from his usual custom, as possessing some narrative coherence-as an 'Entertainment, through the medium of a Domestic Story ... replete with all that variety of which its subject is capable'. ${ }^{12}$ But it is difficult to reconstruct whatever domestic story it might have told, beyond observing that each of the main characters seems to have given Dibdin an opportunity to sing a song in their voice. The two songs that the Oracle reviewer rightly predicted would be 'uncommonly popular', 'The Voyage to Margate' and 'Jacky and the Cow', were both marked by 'strong humour' and apparently designed to display Dibdin's skills in imitating dialects and accents. ${ }^{13}$ The characters involved in the Margate song are familiar individually, rather than as a group, from the eighteenthcentury stage. A print representing the scene on the hoy, published by John Fairburn in 1804, shows them in characteristic attitudes (Figure 8.1).

Central to the scene are the plump figures of Alderman and Mrs Garbage, with their son Dicky. Their stoutness here is part of the convention that takes physical girth to signify vulgar materialism. Her white dress indicates her inappropriately girlish vanity, while his cravat of vomit is a mark of the physical discomfort that results from excessive consumption-the stout alderman at the seaside is typically represented as consuming turbot while his wife gambles and drinks. To their left are Captain Squash and Sir Phelim O'Drogheda, both probably hard-up fortunehunters of the kind so often represented as a threat to the daughters of rich city men. In the foreground the quack doctor Quibus doses the aging Dolly Drylips from what looks like a brandy bottle, while behind him Shadrach clutches the money box of the Jewish merchant (that he is a merchant and money-lender rather than a peddler may be confirmed by the jocular waterman's question, 'Are you a bull or a bear?' in the second spoken interlude of the song). In a pink skirt is the typically flirtatious and petite Miss Minikin, a character most familiar from Samuel Foote's A Trip to Calais, where her mother announces that she will never take a boat trip again, 'unless a-pleasuring, perhaps, during the summer, in a hoy to Margate'. ${ }^{14}$ In the left foreground, holding the picnic basket, is a black servant who may figure Dibdin's presence in the scene, in allusion to his most successful stage

12 Oracle (25 December 1795). 13 Oracle (28 December 1795).

14 Samuel Foote, A Trip to Calais: A Comedy in Three Acts ... to which is annexed, [with R. Colman] 'The Capuchin'(London, 1778), 18. Minikins also appear in Garrick's Bon Ton; or, High life above stairs (London, 1775) and John Hill's The Rout. A Farce (London, 1758?), as well as Kane O'Hara's Midas. A Burletta (London, [1790]). 


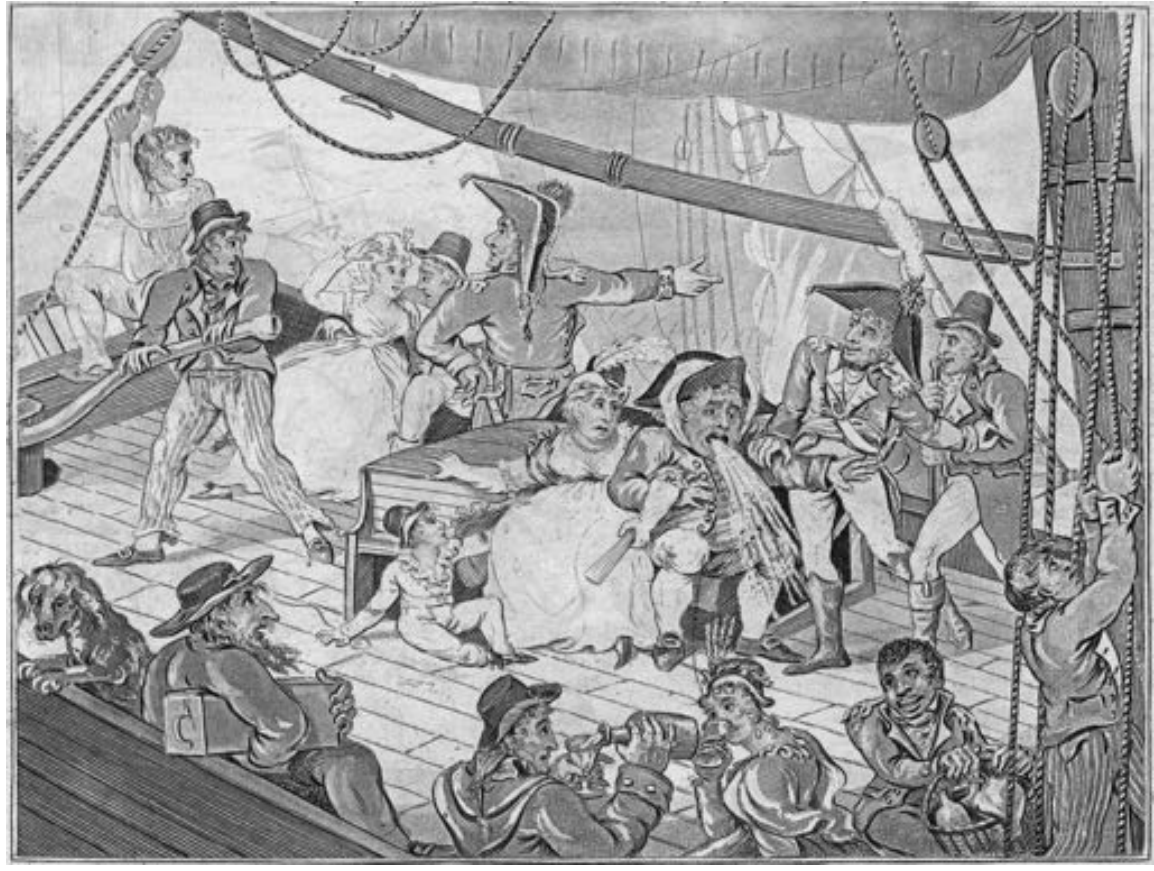

Figure 8.1. A Scene on Board a Margate Hoy, as described by Dibdin. London, 7 January 1804. Hand-coloured etching. Courtesy of The Lewis Walpole Library, Yale University.

role as Mungo in The Padlock (discussed by Felicity Nussbaum in Chapter Two of this volume). Dibdin remained closely identified with this part, and took pride in the number of people who claimed to remember his performance, even though he expressed doubts about the accuracy of their memories. ${ }^{15}$

The familiarity of the characters in Dibdin's work was clearly important to its success. Hostile critics suggested that Dibdin was guilty of recycling both the work of other writers and musicians and his own earlier compositions. To give only a small sample, the Theatrical Review in 1771 accused him of 'repeated plagiarisms', ${ }^{16}$ and the European Magazine, in a largely sympathetic account of his life and career published in 1784, conceded that he does not possess an infinite fund of variety'. ${ }^{17}$ John Williams, writing as Anthony Pasquin, wrote, 'Like some Misers who laughably subdivide pelf, / He reviews his own bank and cribs notes from himself.' 18 Most acidic were perhaps the comments of Benjamin Crosby, who concluded in his Pocket Companion for 1796 that Dibdin's writing was 'deficient in

15 See Life, 1:199-200.

16 'Theatrical Review for December 1771', in The Theatrical Review; or, New Companion to the Play-house, 2 vols (London, 1772), 1:303.

17 'Impartial and Critical Review of Musical Publications', European Magazine 6 (1784): 360.

18 Anthony Pasquin [John Williams], The Children of Thespis (13th edn, London, 1792), 29. 
wit, genius, fancy and invention', and asserted that in his published songs 'there is not a new phrase, nor any expression which has the appearance of originality, which may not be found in Roderic Random'. ${ }^{19}$ Crosby's comment (presumably prompted by the name Tom Bowling which Dibdin had borrowed from Smollett's novel) would have stung, as a close kinship and sympathy with sailors, and the privileged expertise in nautical vocabulary this produced, were central to Dibdin's professional identity and reputation. For an account of the accusation that Dibdin had plagiarized Bickerstaff, see David Kennerley's discussion in Chapter Five of this volume.

It is, however, certainly the case that in songs such as those which make up the Christmas Gambols of 1795, characters do not stray from the track beaten by their theatrical predecessors and types. But this was of course a critical feature in Dibdin's success. The Edinburgh Magazine observed in 1782, relatively early in Dibdin's career, that his critics often judged him 'without knowing or remembering' the range of works for which he was responsible, and which tended almost to float free of his authorship. ${ }^{20}$ He worked with clearly recognizable characters who were part of the familiar representational currency of everyday life; characters whose clearly demarcated differences and distinctions lent stability and clarity of definition to the 'monstrous and unfathomable gulph, filled with contradictory and heterogeneous materials' which so alarmed and upset Dibdin's rather cautious and conservative view of the world, but were also essential to his capacity to extract humour and sentiment from it. He incorporated these characters in melodies the simplicity of which he regarded as a matter of pride and indeed as a national characteristic (as Cox Jensen discusses in Chapter Seven of this volume). Those who admired his talents praised the clarity of his delivery, which was such that 'every word he uttered was easily intelligible', for, as William Kitchiner noted with approval in his memoir of Dibdin, 'he had that sensible idea about Vocal Music, that the true intention of it is, to render the Words more impressive'. ${ }^{21}$ His 'remarkably distinct articulation' and knowledge of 'when to Speak a Word, and when to Sing it ${ }^{22}$ combined with clear melodies and familiar characters to create ballads which were perhaps intended to sound as though they had been heard before, and to conjure nostalgia for a united nation ruled by the ideal (and conspicuously fictitious) family Dibdin celebrated in his 'Ode on the Nuptials of the Prince and Princess of Wales' (1795).

\section{DIBDIN AND GRAPHIC PRINT}

Dibdin's 'The Voyage to Margate', like the comments on Margate in his Tour, builds on the reputation of the resort and the hoy that was already well established across the genres of newspaper reports and gossip, travelogues and sentimental journeys, novels, dramatic comedies, and satirical or sentimental verse. But the

19 Crosby, Pocket Companion, 104.

20 Edinburgh Magazine 55 (4 April 1782).

21 Kitchiner, $24 . \quad 22$ Ibid., 24, 25. 


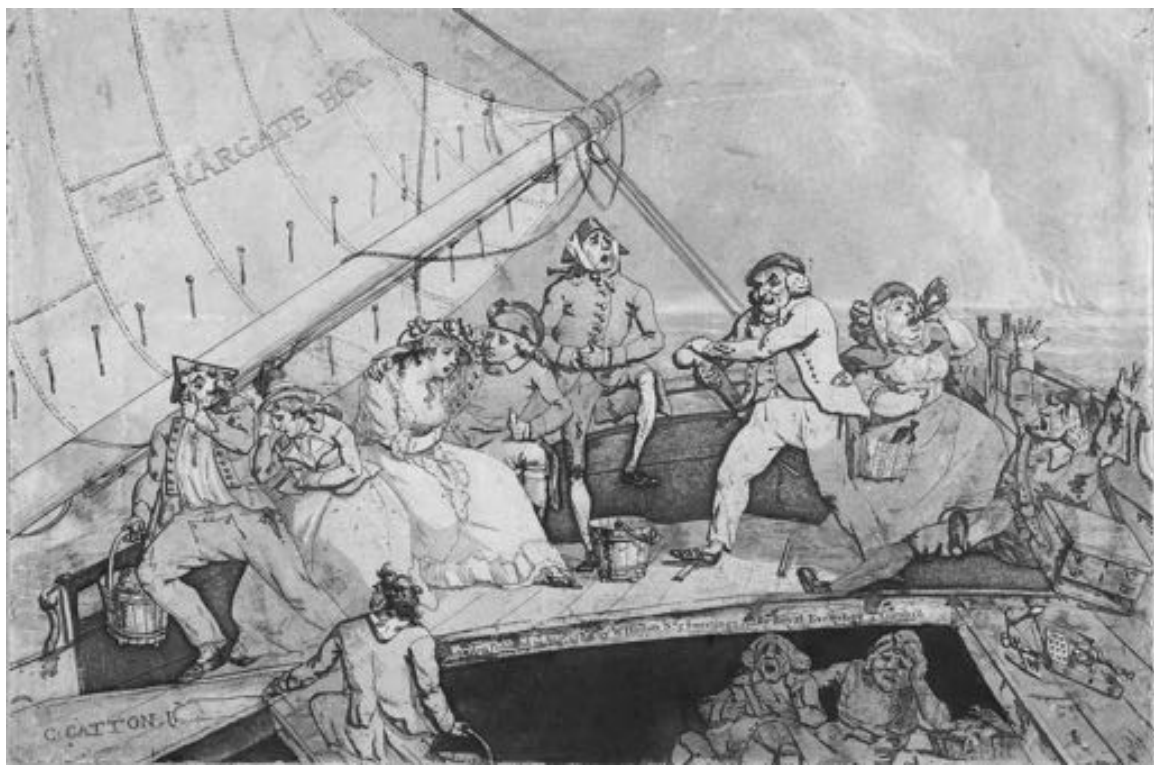

Figure 8.2. Charles Catton the Elder, Margate Hoy. London, 19 August 1785. Hand-coloured etching. Auchincloss Rowlandson Collection, Beinecke Rare Book and Manuscript Library, Yale University.

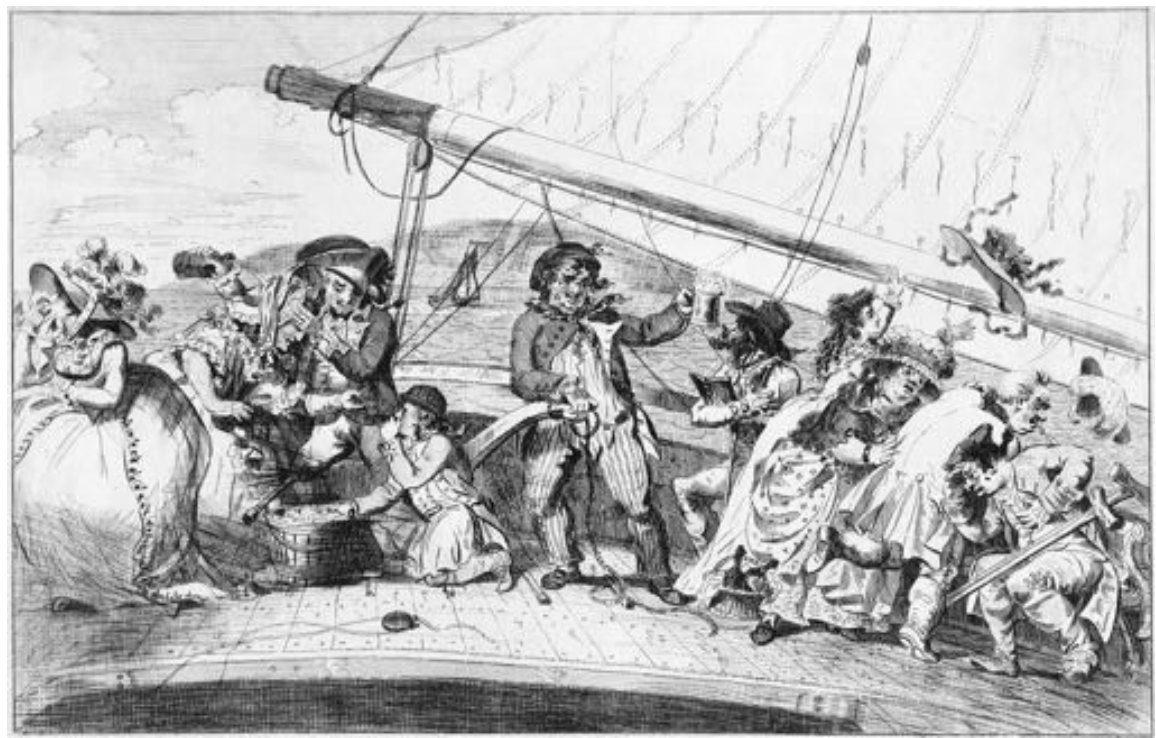

Figure 8.3. Isaac Cruikshank, Voyage to Margate. London, 1 January 1786. Hand-coloured etching. Courtesy of The Lewis Walpole Library, Yale University. 
success of Dibdin's work is not only about performance; in addition to its theatrical and textual aspects, it also draws on graphic satire, and there is an intriguingly close relation between the song he performed in 1795 and two prints published ten years earlier by William Hinton. The earlier of the two is a print of the deck of 'The Margate Hoy' by Charles Catton the Elder, published on 19 August 1785 (though obscured text in the darkened space below the credit line gives the earlier date of 10 May 1785 (Figure 8.2)).

It clearly portrays several characters similar to those who later appear in Dibdin's song, including the Jewish merchant and the Garbages, as well as figures who might be recognizable as versions of Dolly Drylips, Miss Minikin, and the fortunehunters. In January 1786, Hinton published a second print showing the deck of the hoy by Isaac Cruikshank, titled $A$ Voyage to Margate, which again portrays some of the principal characters from Dibdin's song (Figure 8.3).

We can readily identify in the print, reading from the right to the left, the Alderman and his wife, the young and attractive girl Dibdin names Miss Minikin, the Jewish merchant, and a middle-aged women (Dolly Drylips?) apparently being ministered to by an older man (Dr Quibus?) who wields a bottle while she throws up into a bucket. It is of course not at all surprising that there should be a close relation between the characters depicted in caricatures and on the stage. A print of Dibdin playing Mungo in blackface had appeared in 1769, for example, and there were at least six different portraits of him in circulation as prints or paintings by the time of his death. But for prints to have appeared ten years before the representation of a very similar event in a popular song is more striking. And it may be a sign of the close attention Dibdin paid to graphic material as a source for his songs.

In his prose works, Dibdin frequently returns to the theme of the success of his songs, on which, understandably enough, he liked to congratulate himself. $\mathrm{He}$ records the sums he had received for many of his entertainments and songs, usually railing against those who had made more money out of them than he had, and he also notes the number of nights performed and copies sold. The posthumous 1823 edition of his sea songs, assembled by Kitchiner, provides a convenient compilation of these notes, which demonstrate the keen interest Dibdin took in the marketing of his work. Dibdin notes that he published 10,750 copies of his popular song 'The Greenwich Pensioner', from which he made more than $£ 400$, and that 'Poor Jack', which he found difficult to shift, had 'spread itself all over the kingdom' once he sold it on. ${ }^{23}$ The European Magazine argued that Dibdin's extraordinary success derived from his 'wish to amuse and instruct his countrymen in a manner at once patriotic and moral', and to be 'in every thing national'. ${ }^{24}$ And Dibdin represented the keen interest he took in the circulation of his work and his own increasing fame as supplementary to the patriotism that characterized all of his songs and stemmed 'from inclination ... and from duty, as a good subject'. ${ }^{25}$ But what was so distinctive about Dibdin's professional career was the success attributed to him in appealing to mass audiences. Reverend James Plumptre noted that Dibdin's 'works 
circulate through all ranks, from the elegant drawing-room to the humble cottage, and the vessel upon the ocean'. ${ }^{26}$ Dibdin himself observes of the six hundred songs included in his Life, 'With all these the streets have echoed, and barrel-organs and other mediums have proclaimed their popularity,' and claims to have proof that his songs had been the 'solace of sailors on long voyages' (see Isaac Land's discussion of the popularity of Dibdin's songs among sailors in Chapter Eleven of this volume). ${ }^{27}$ Pasquin observed, without admiration, that Dibdin used 'Vulgarity's wiles' to transform his material, which he repaired and reused like a darned old sock, in order to 'illustrate low trash and inveigle base throngs' ${ }^{28}$ The mid-nineteenthcentury collection of his Songs, Naval and National produced by his son Thomas, however, boasted the patronage of royalty, as well as of the Lords of the Admiralty, and includes an extensive subscription list of the wealthy and titled elite.

The size and diversity of the audiences for Dibdin's songs was obviously important to his moral and patriotic ambitions as well as to his commercial success. But audience numbers at the Sans Souci were constrained by the size of the theatres-Dibdin remarked that the measurements of the two spaces the theatre occupied in succession were the same-and by the price of tickets, which ranged from $2 \mathrm{~s}$. in the gallery to $5 \mathrm{~s}$. per box (or 'colonnade and bowers' in the first Sans Souci). ${ }^{29}$ When he performed in Harrogate for one night in July 1800, tickets were 3 s. apiece. ${ }^{30}$ These prices do not support his ambition to sing for and to a general and inclusive audience. Volumes containing collections of his songs made them available to 'elegant drawing-rooms' beyond the theatre, but the most effective means of achieving a wider distribution was through sales of slip-songs and song sheets. While Dibdin did not always have any direct control over these, as he sold many of his songs outright, or wrote them for a fixed payment, and, in addition, as piracy was rife in the industry, they would nevertheless have contributed to public perceptions of him as a songwriter, and would also have encouraged him to keep a watchful eye on the song sheets and prints in circulation. These cheaper forms varied from slip-songs, sometimes accompanied with a woodcut vignette or design, often costing a halfpenny apiece (e.g. Figure 8.4), to single sheets containing detailed images in the body of the song (e.g. Figure 8.5), or pages where half the space might be taken up with a more elaborate printed scene, and which were usually sold for 6d. plain or 1s. coloured (e.g. Figure 8.6).

Particularly in Dibdin's later years, from the late 1780s till his death in 1814, these prints could take the form of quite finely produced drolls, often-though by no means exclusively_produced by the publishing houses of Samuel Fores

26 Postscript to James Plumptre, A Collection of Songs moral, sentimental, instructive, and amusing (London, 1805), 32, cited in Kitchiner, 9n.

27 Life, 1:6.

28 Anthony Pasquin [John Williams], The Pin-Basket to the Children of Thespis (London, 1797), 70, and Children (1792), 29.

29 See, for example, True Briton (19 March 1795); for ticket prices at the Sans Souci, see advertisements available at Eighteenth-Century Collections Online.

30 Playbill, For One Night Only. Sans Souci. The Inhabitants of Harrogate and its Vicinity are Respectfully Informed, that on Wednesday, July 23, 1800, at the Theatre, Harrogate, will be performed, A New and Popular Entertainment, called Tom Wilkins (Knaresborough, 1800). 


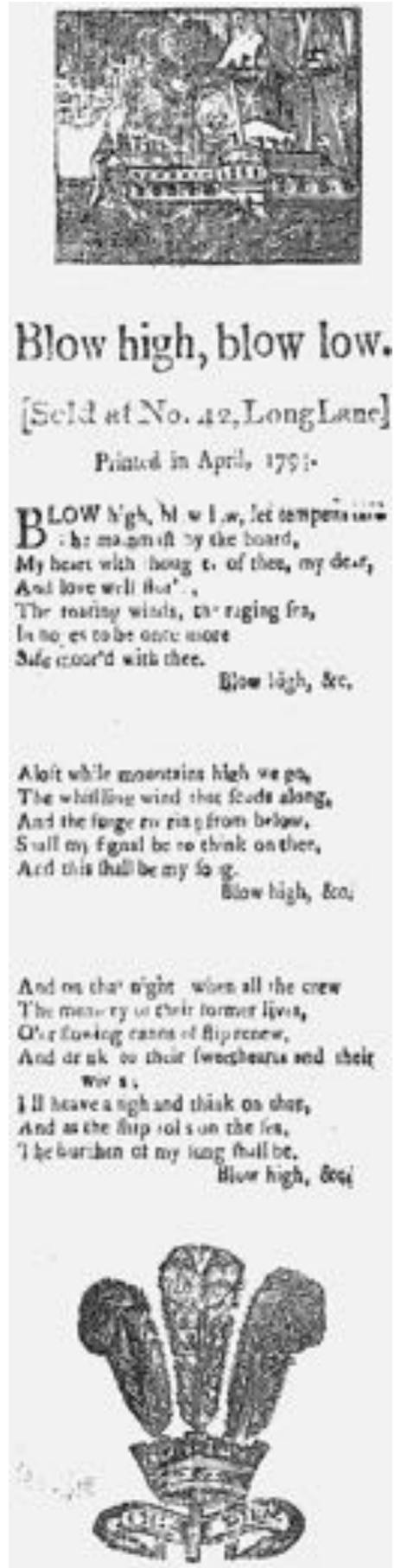

Figure 8.4. Charles Dibdin, 'Blow high, blow low'. London, 1794. Song slip, the Bodleian Libraries, the University of Oxford, Harding B 11 (334). 


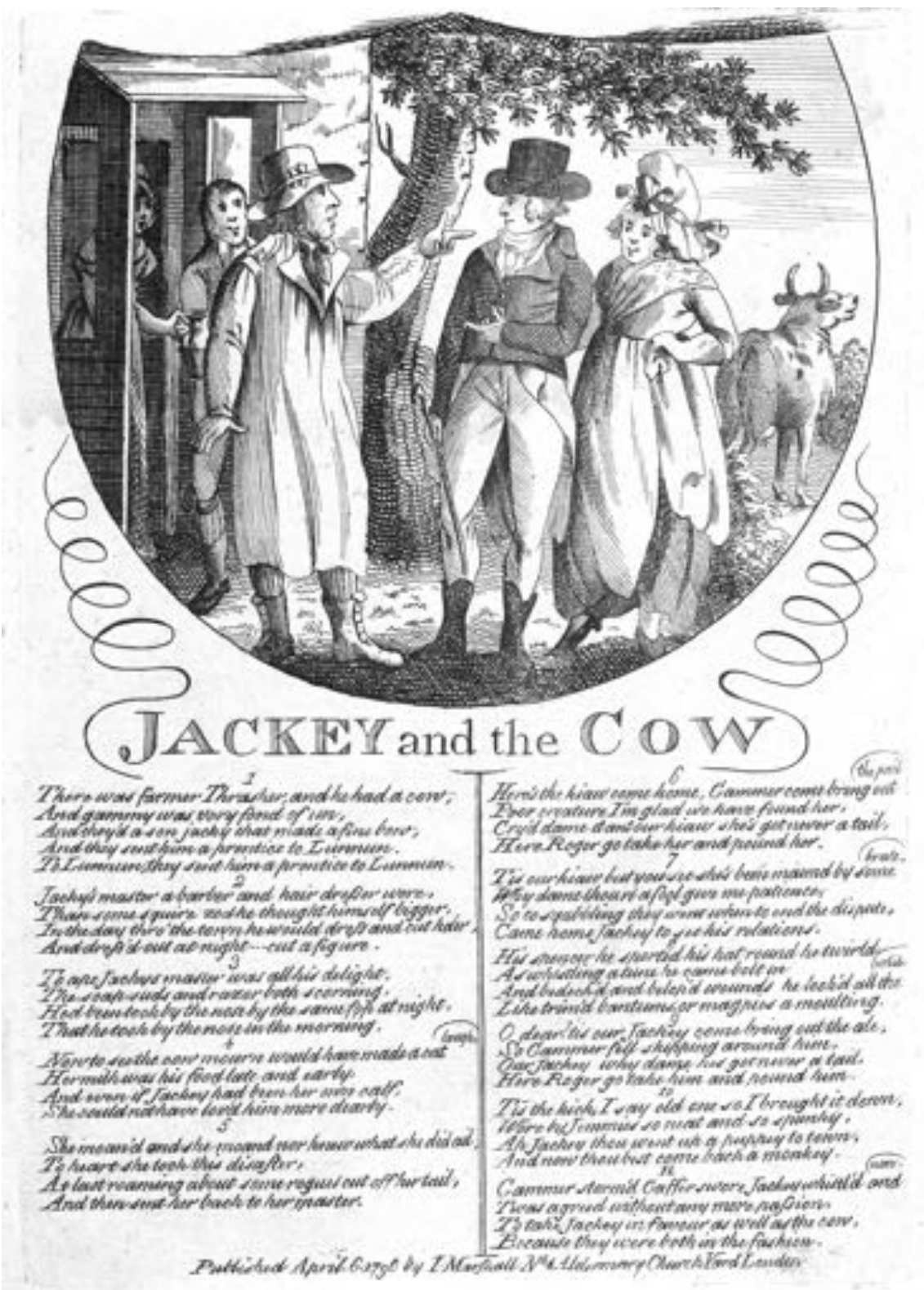

Figure 8.5. Charles Dibdin, 'Jackey and the Cow'. London, 1796. Engraving. (C) Museum of London. 


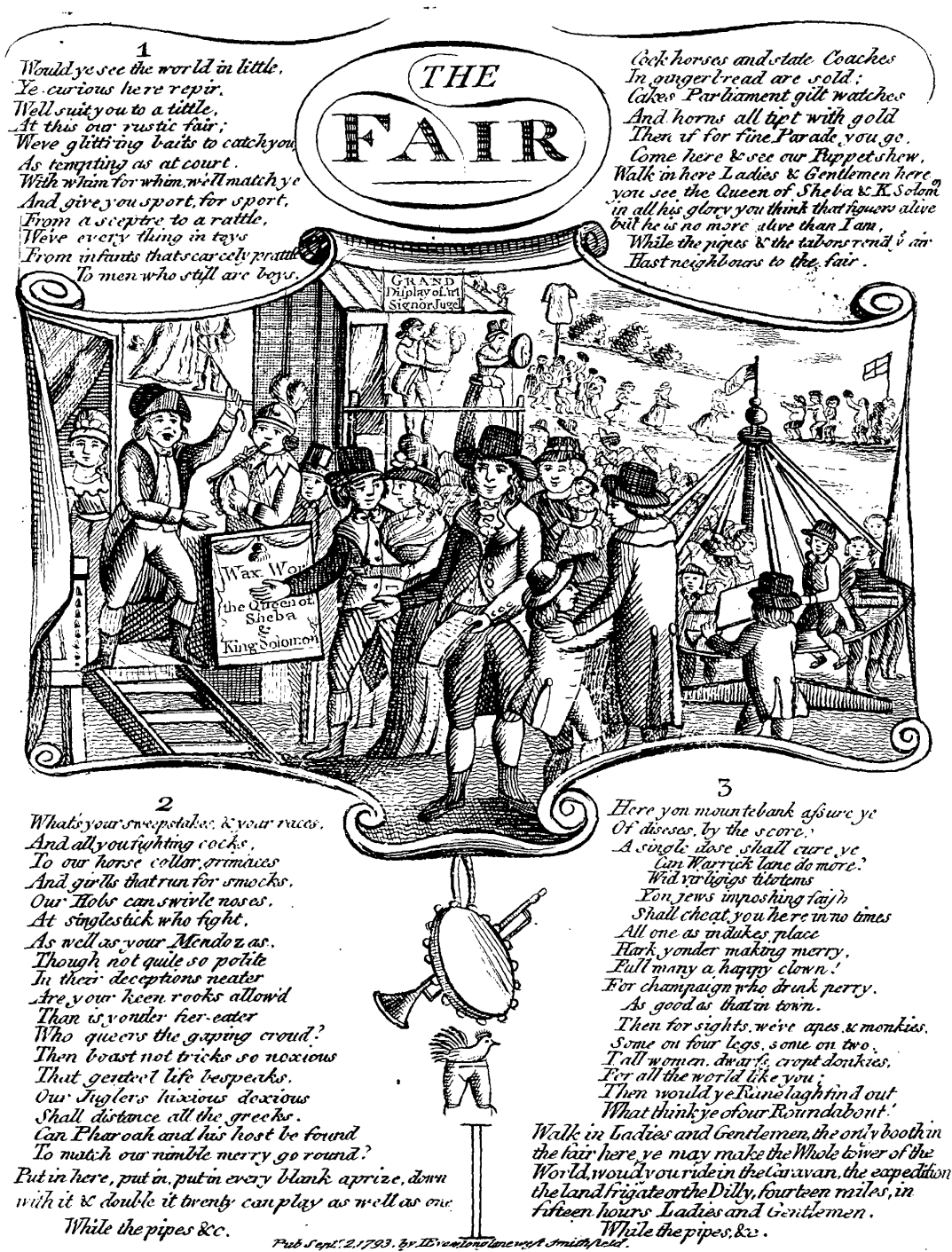

Figure 8.6. Charles Dibdin, 'The Fair'. London, 1793. Engraving, The Bodleian Libraries, The University of Oxford, John Johnson Collection: Ballads, fol. 357a.

(e.g. Figure 8.7) or of Laurie and Whittle (e.g. Figure 8.8, which possibly uses plates produced under the imprint of Robert Sayer before they took over the business).

The prints from Laurie and Whittle can often be found detached from the song beneath, which might be the result of folding the paper, but might also be a sign of the frame-worthy quality of the images. ${ }^{31}$ In some of the prints published by Fores

31 See, for example, the prominent fold in one Fores edition of 'The Greenwich Pensioner': British Museum 1985,0119.125. 
OUP UNCORRECTED PROOF - REVISES, 20/10/2017, SPi

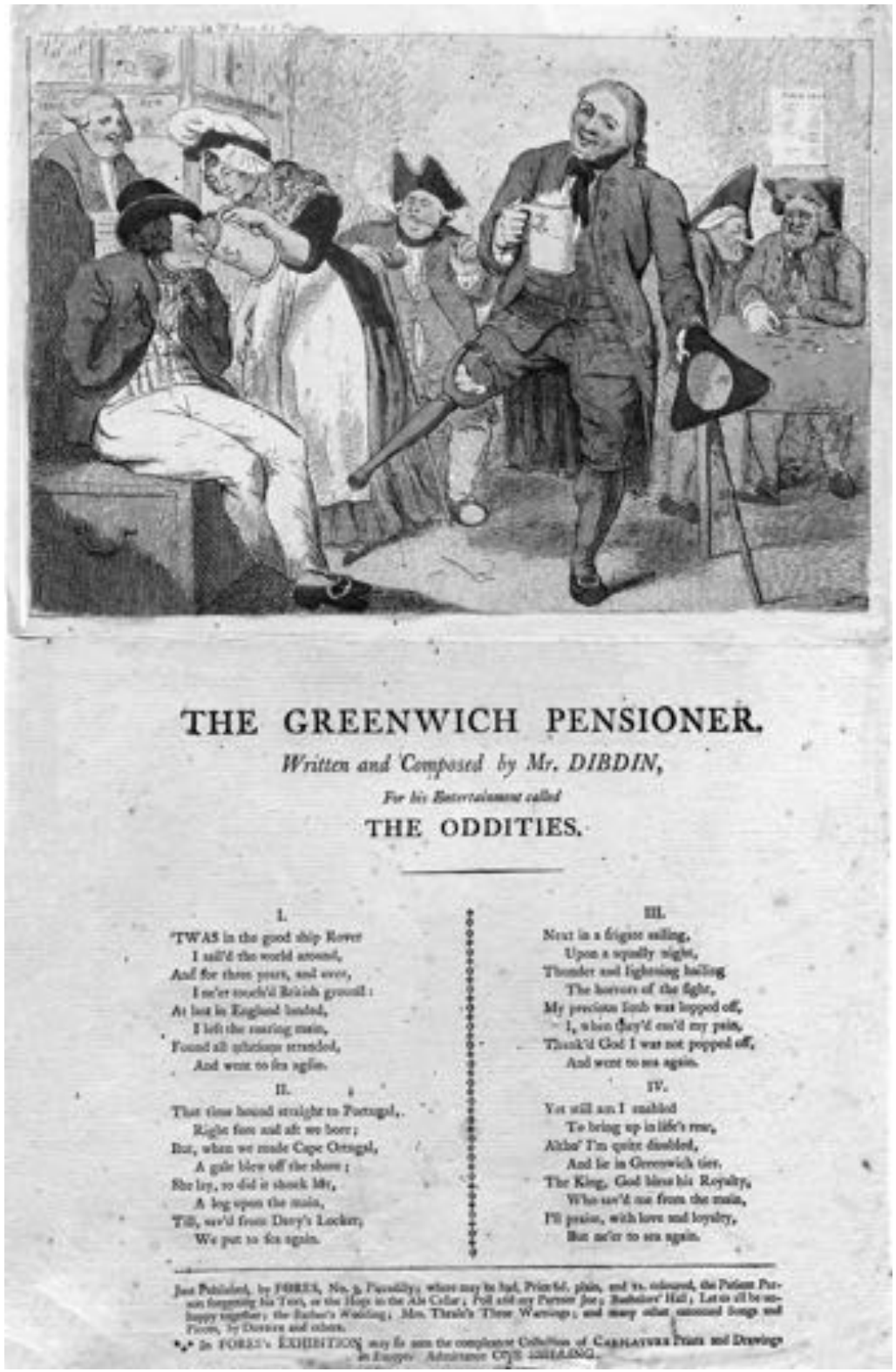

Figure 8.7. Charles Dibdin, 'The Greenwich Pensioner'. London, 1791. Hand-coloured etching. Courtesy of The Lewis Walpole Library, Yale University.

the line identifying the date and place of publication seems to have been moved to an awkward position immediately beneath the image, as if to ensure that it will not be lost when the text beneath is removed. But the preservation of the top half of the sheet where the image appears does seem to indicate the familiarity of the context for the image, as though the allusion of title and perhaps the style of the drawing, 

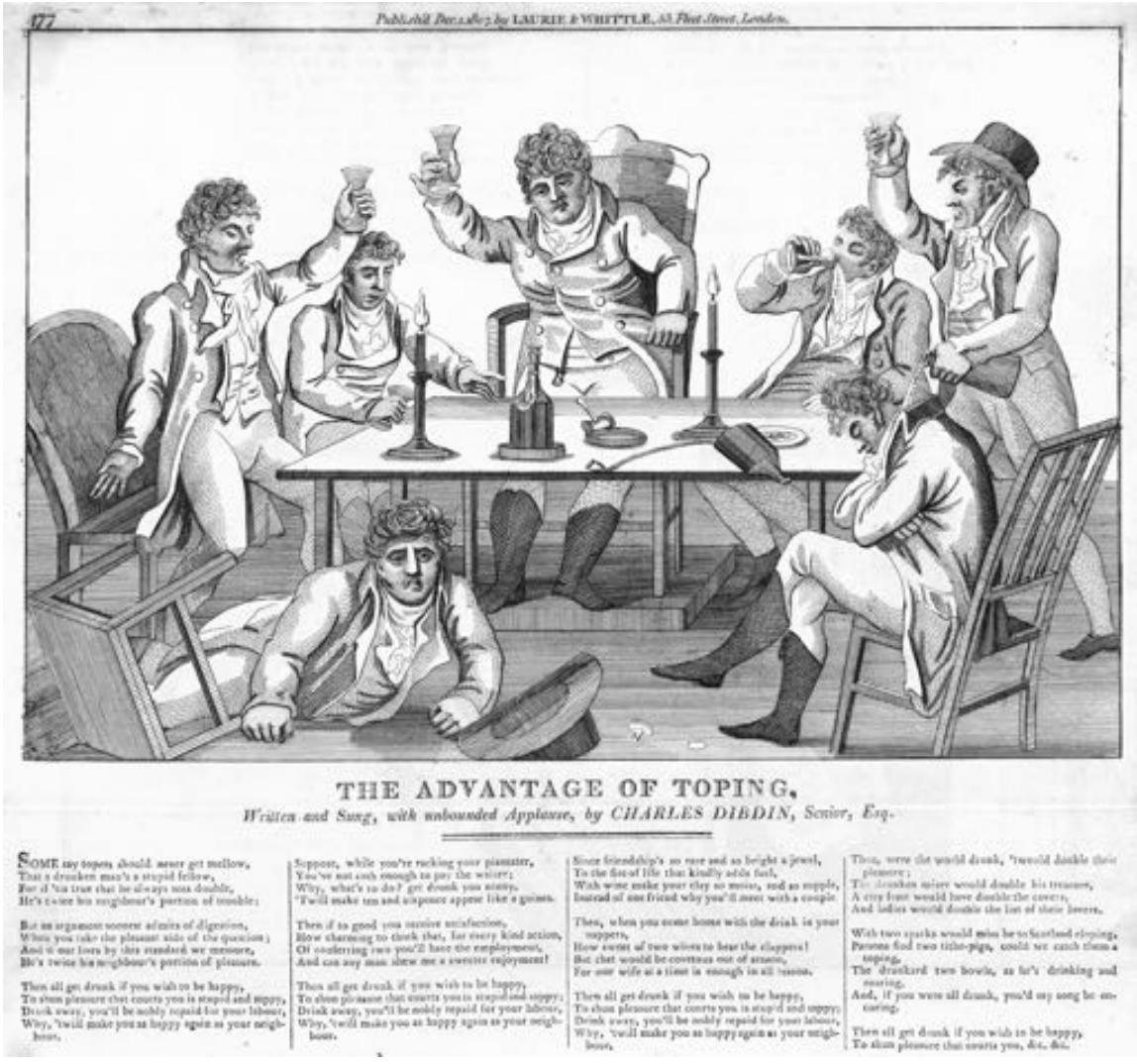

Figure 8.8. Charles Dibdin, 'The Advantage of Toping'. London, 1807. Etching. Courtesy of the Trustees of the British Museum.

appropriate to sentiment or humour, is all that is needed to call the song to mind. In prints such as Fairburn's of 'The Margate Hoy', or some of those showing 'The Greenwich Pensioner', only a verse or two of the song is reproduced. The text beneath the two prints by Robert Clamp (after George Morland) published in 1797- 'The Contented Waterman' (Figure 8.9), and 'Jack in the Bilboes' (Figure 8.10)—does not even name the song ('My Poll and My Partner Joe'), but merely identifies with a line the scene the image depicts.

William Ward's superior mezzotint engravings after the same two Morland paintings, published in 1790 and 1806 (Figures 8.11a and b), give merely a brief line in much smaller print (often trimmed from the image as it has been in the British Museum copy), as though the customers for these larger and more expensive prints could readily have identified their musical source. Morland's illustrations of Dibdin's songs are discussed in greater depth by Nicholas Grindle in Interlude Three of this volume. 


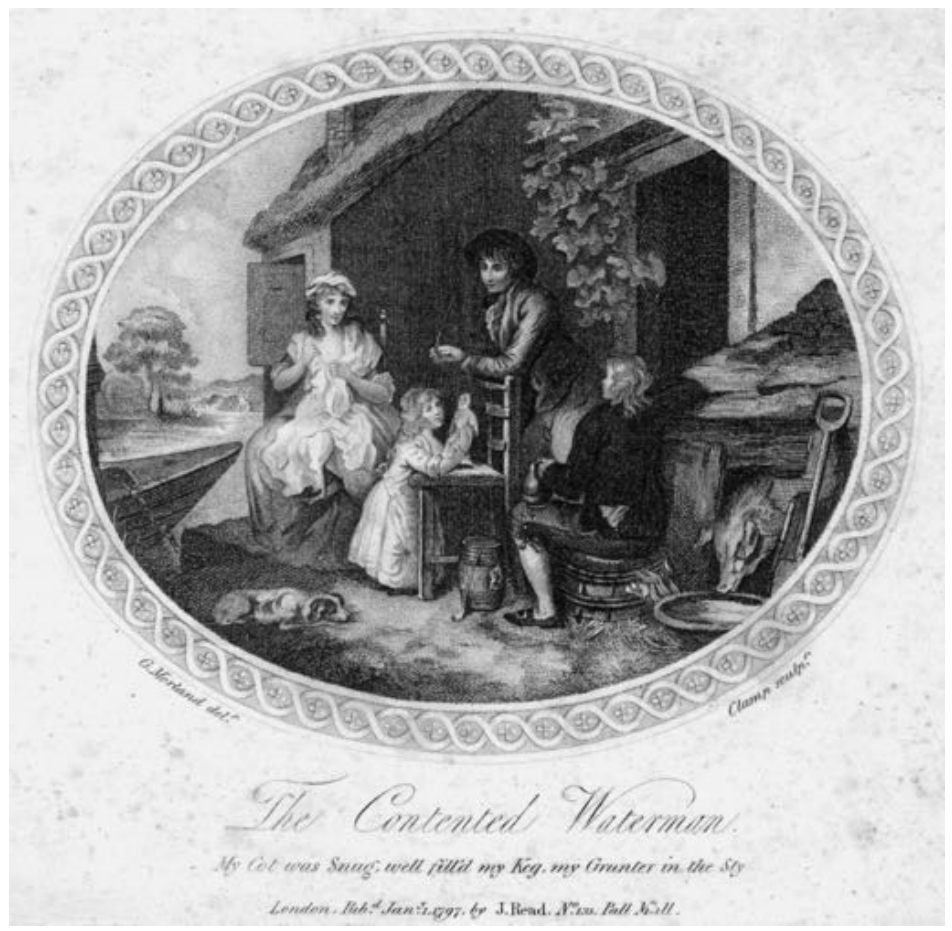

Figure 8.9. Robert Clamp after George Morland, The Contented Waterman. London, 1797. Stipple etching. Courtesy of the Trustees of the British Museum.

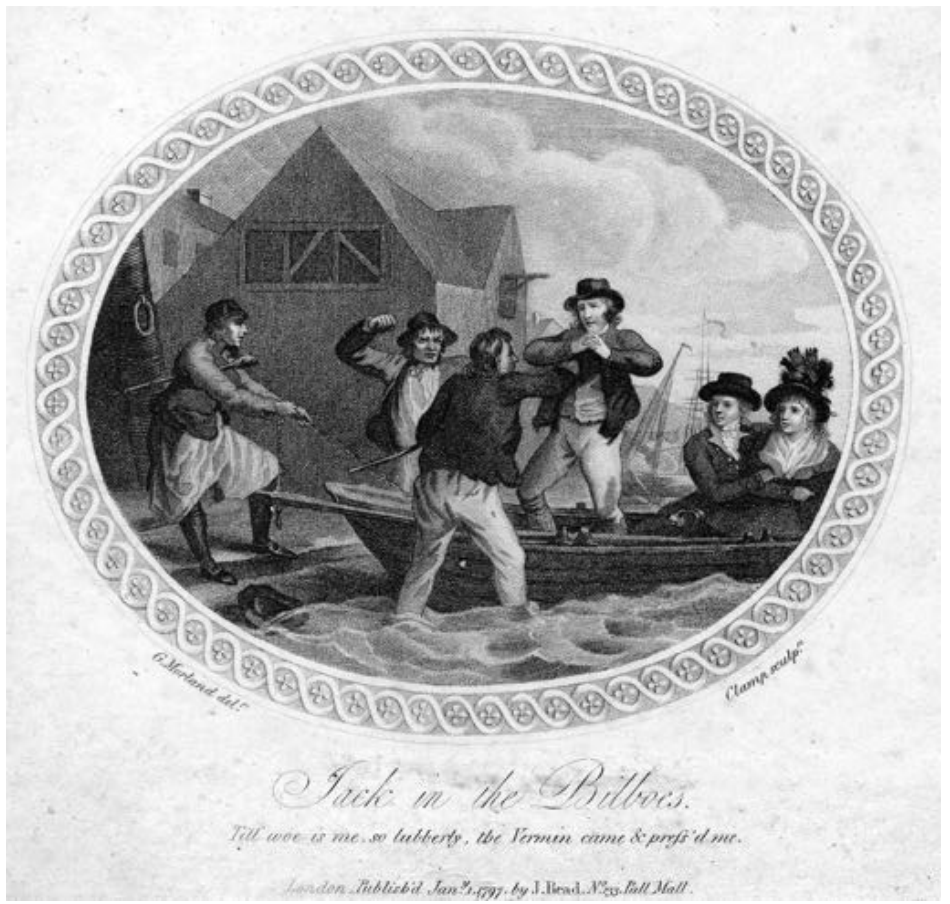

Figure 8.10. Robert Clamp after George Morland, Jack in the Bilboes. London, 1797. Stipple etching. Courtesy of the Trustees of the British Museum. 
(a)

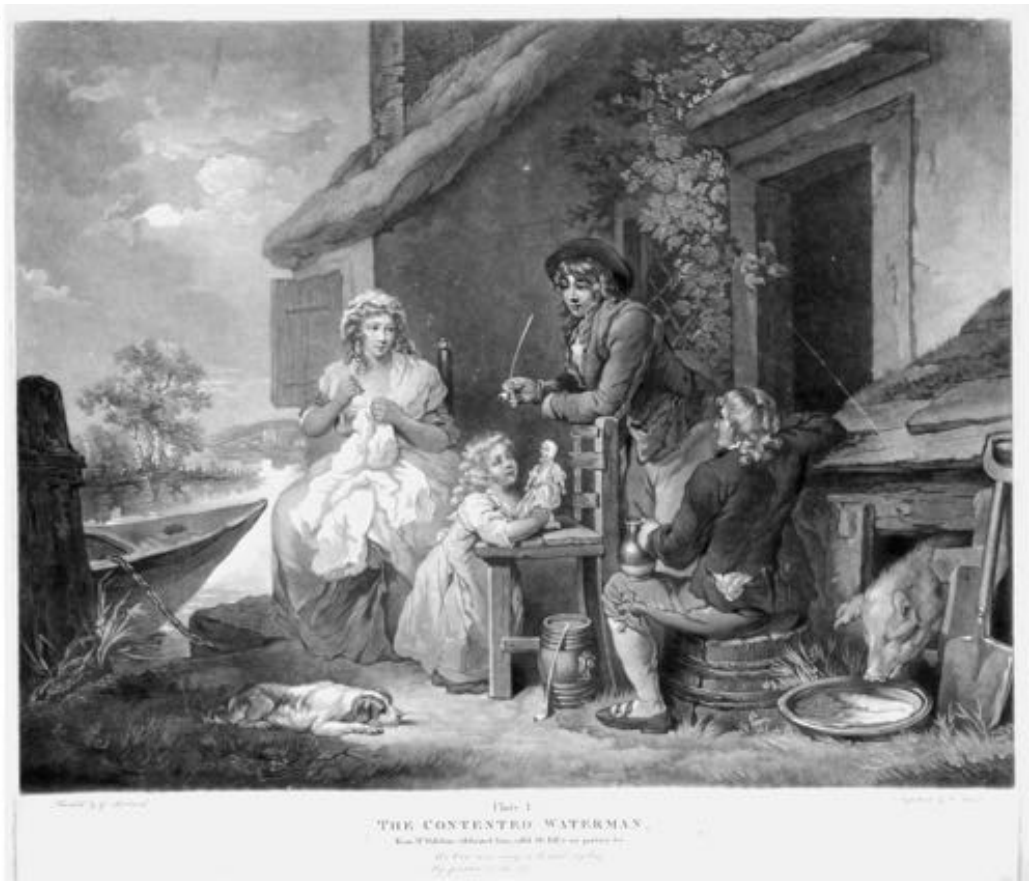

(b)

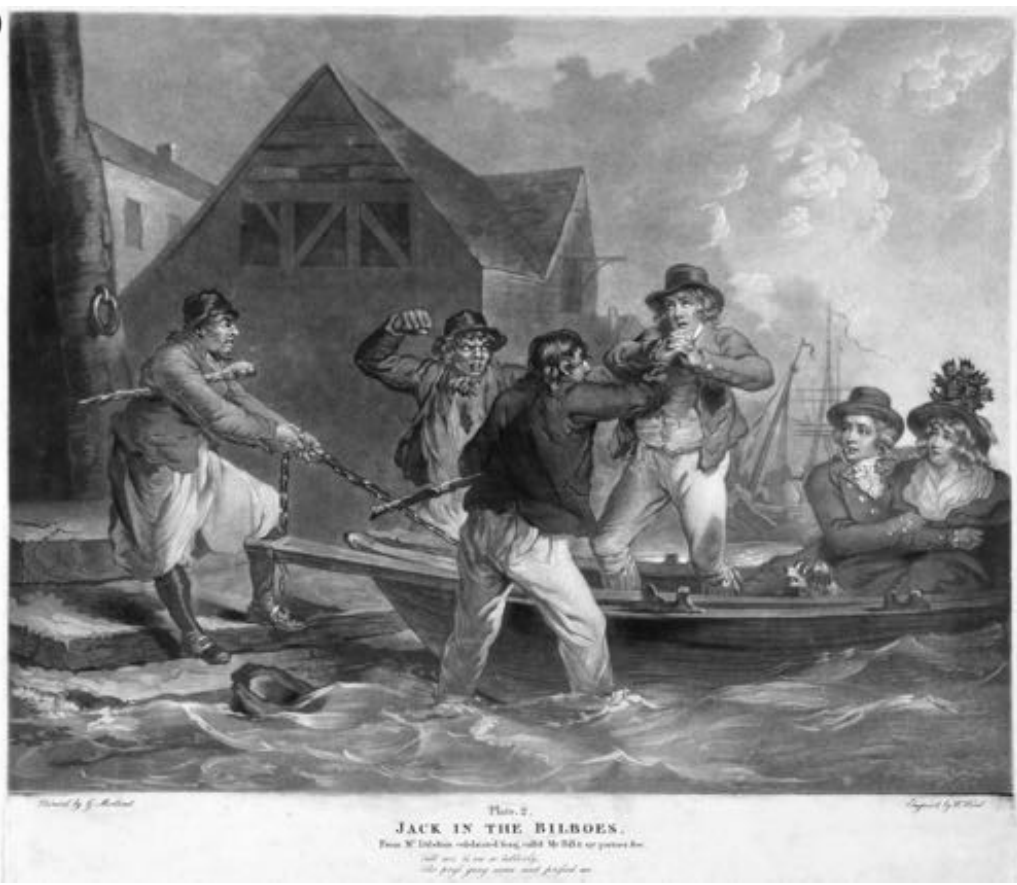

Figure 8.11. (a) William Ward after George Morland, The Contented Waterman. London, 1806. Mezzotint. Courtesy of the Trustees of the British Museum. (b) William Ward after George Morland, Jack in the Bilboes. London, 1790. Mezzotint. Courtesy of The Lewis Walpole Library, Yale University. 
OUP UNCORRECTED PROOF - REVISES, 20/10/2017, SPi

Dibdin clearly attached considerable importance to advertising and popularizing his work. He used broadsides to announce his performances, apparently posting new sheets for every appearance at the Sans Souci in the Strand in the autumn of 1793, and he also advertised extensively in selected newspapers, placing notices regularly, and with great frequency, in papers such as the True Briton, the Oracle, the Morning Post, and the Public Advertiser. The diversity of forms in which individual songs were published indicates that he and the booksellers who marketed his songs (with or without his consent) grasped the significance of graphic material in making the song sheets attractive and memorable. But the 'Voyage to Margate' indicates that Dibdin did not regard images as supplementary to his songs, or as attractive decoration distinct from the processes of composition and performance. Dibdin's song might have drawn on William Hinton's prints of 1785 and 1786, but that relationship is given added depth by the publication, again by Samuel Fores, of a print of the 'Margate Hoy' by Thomas Rowlandson which is based closely on Charles Catton's image of the same title, and which first appeared on 12 January 1795, less than a year before the first performance of Dibdin's Christmas Gambols (Figure 8.12).

Charles Catton Senior (1728-98) was a founding member of the Royal Academy, best known for his work as a coach painter. He introduced a more naturalistic representation of supporting animals to the heraldic devices that ornamented the vehicles of the landed elite. But he also produced a number of sketches in a style strikingly similar to that of Rowlandson, to whom some of his work has been

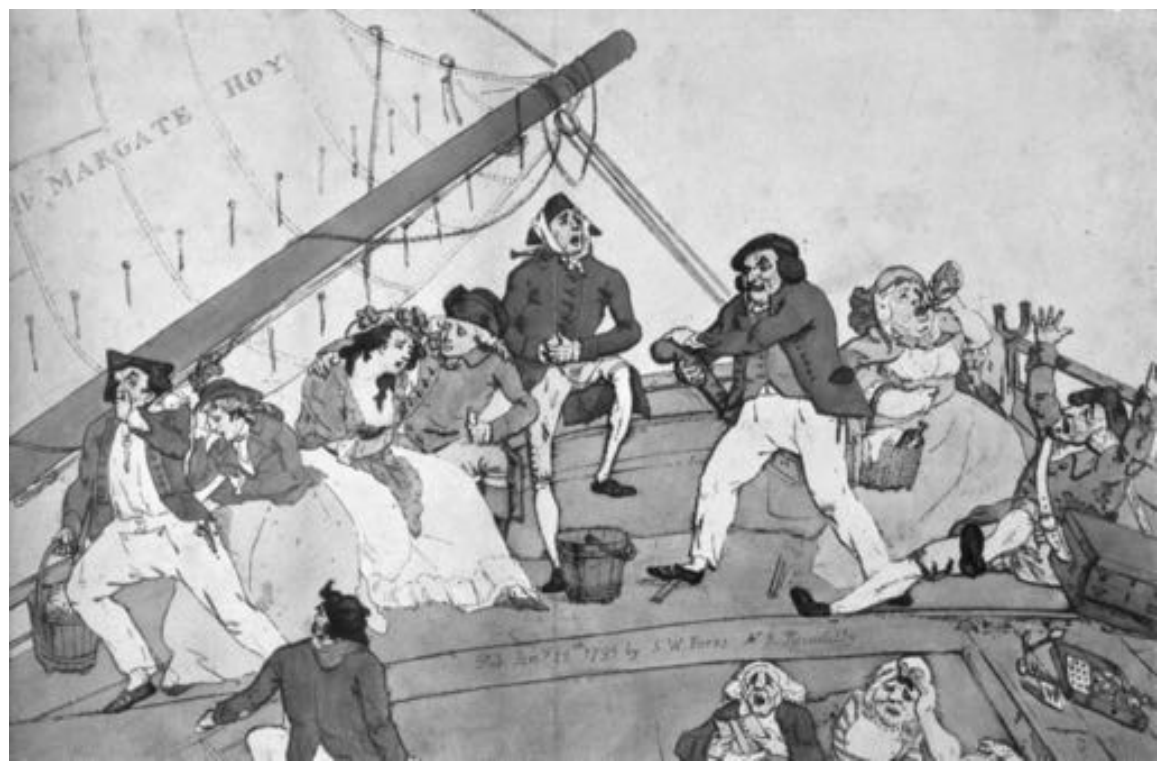

Figure 8.12. Thomas Rowlandson, Margate Hoy. London, 12 January 1795 . Hand-coloured etching. Private collection. 
misattributed, and it seems likely that these influenced the developing style of the younger caricaturist, possibly during his attendance at the Royal Academy schools. Rowlandson's 'Margate Hoy' suggests a still closer relation, as it resembles Catton's earlier print so precisely that it looks like a reworking of the same plate. Rowlandson and Fores had made use of Catton's image before, in a print of 4 August 1789 titled 'A Fresh Breeze', which was a satirical reworking of the scene on board the hoy (Figure 8.13).

Here Catton's queasy passengers are replaced by the king and members of his family and entourage as they voyage out to HMS Southampton, a thirty-two-gun frigate loaned to them during their summer tour of the southwestern counties. The print alludes to newspaper stories that suggested that the royal family sometimes found their sea trips 'very unpleasant'. ${ }^{32}$ Presumably the cream of the jestcomparing the royal group with a crowd of East-Enders out on a spree-could have been relished only by an esoteric band of cognoscenti who had in their portfolio of prints (or simply recollected) the image Rowlandson had adapted. But the sickness of the party would probably have indicated a vulgarity incongruous with royal dignity even to those spectators who did not catch the Margate reference.

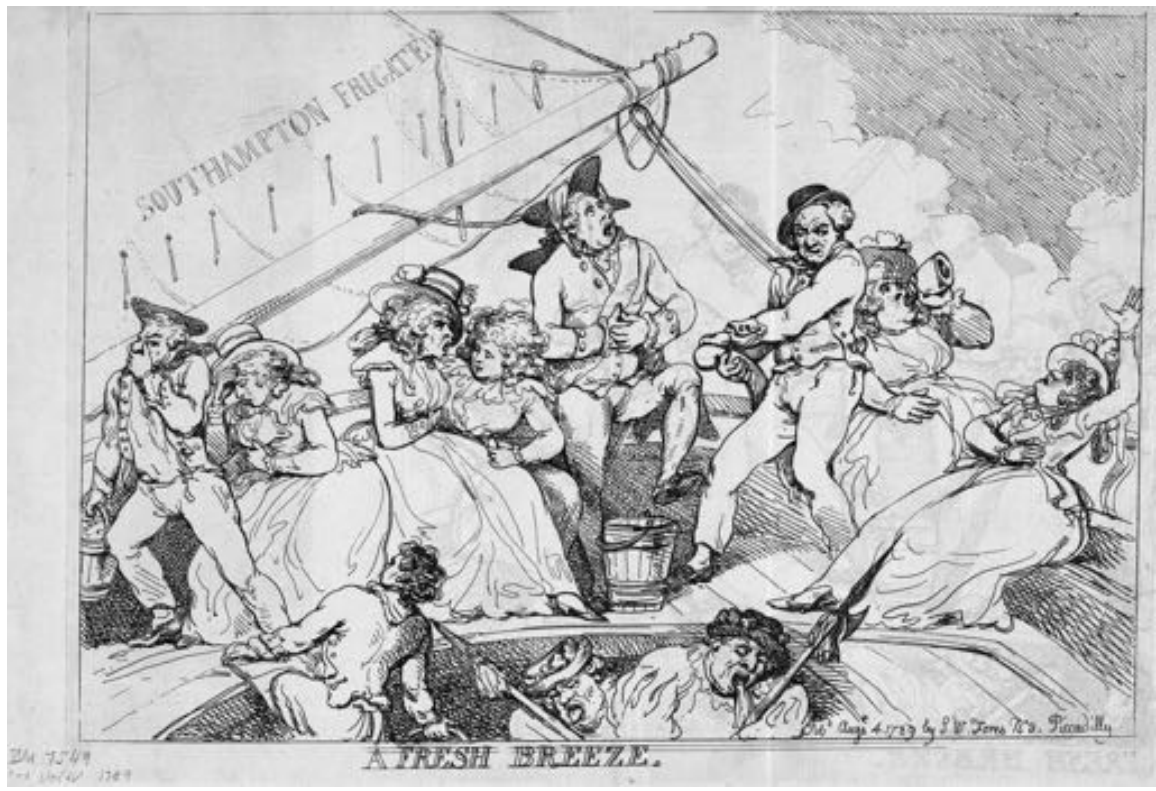

Figure 8.13. Thomas Rowlandson, A Fresh Breeze. London, 4 August 1789. Etching. Courtesy of The Lewis Walpole Library, Yale University. 
OUP UNCORRECTED PROOF - REVISES, 20/10/2017, SPi

When Joseph Palmer published his tour of the Lake District in 1792, he prefaced it with a chapter titled 'A slight touch of a Margate Hoy'. This turned out to be a euphemistic allusion to the nauseous sufferings of the passengers, which Palmer thought it witty to represent at some length. The English Review rebuked the 'coarse, vulgar daubing' with which he depicted the scene, and he brought out a second edition omitting the physical details the reviewer had found so offensive. ${ }^{33}$ Seasickness in texts and perhaps also in images emphasized vulgar physicality, and needed to be handled with care if it was to be a matter for humour rather than disgust. Dibdin's song draws on visual types that were well established in images such as those of Cruikshank, Catton, and Rowlandson. But he is careful to avoid the kinds of references to the physical symptoms of sickness that Palmer had to excise from his humorous venture, and that might have found a visual parallel in the unpleasantly scatological 'Sketch on Board a Margate Hoy' which was produced and published by Piercy Roberts probably after 1795 (Figure 8.14). Roberts's sketch shows a similar cast of characters to those depicted in the prints of Catton, Rowlandson, and Cruikshank, and given voices in Dibdin's song, but it lacks

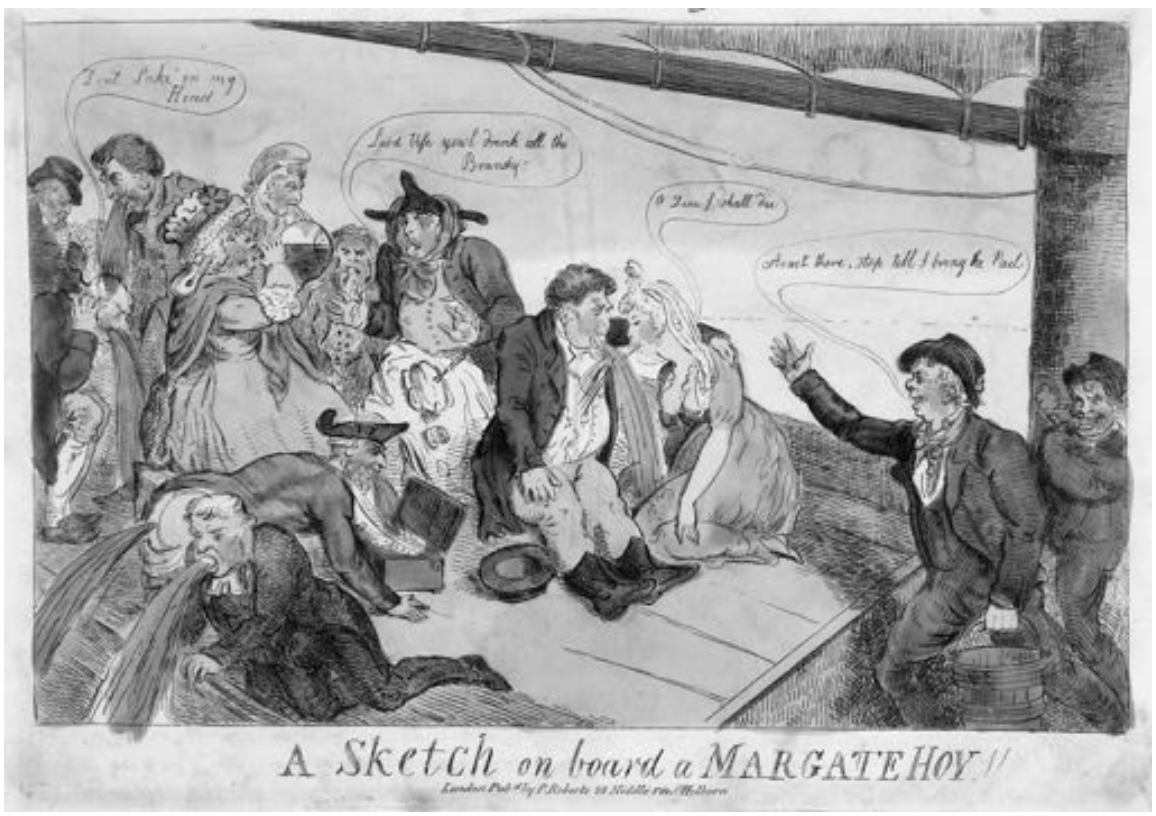

Figure 8.14. Piercy Roberts, A Sketch on board a Margate Hoy!! London, c.1795-1805. Hand-coloured etching. Courtesy of The Lewis Walpole Library, Yale University. (London, 1792), 1; see also the second edition of 1795; English Review (January 1793): 52. 
any suggestion of the good nature or sympathy that made those representations humorous.

When Dibdin's son Thomas included a song for a Margate Hoy-Man in his pantomime Harlequin's Tour, or The Dominion of Fancy, which was performed at Covent Garden in 1800, he chose to emphasize the holiday gaiety of the voyage, 'Crowding together all stations and quality', and listed some of those aboard:

Bucks who hunt fashion like quick scented mousers,

Leave town, it exhibits no sport for you now, sirs,

So pull off your boots and then put on your trowsers,

To join the gay throng, where the sea breezes blow.

Pretty men-milliners, fresh water sailors,

Smart prentices, alderman, actors and taylors,

Let me and old ocean awhile be your jailors. ${ }^{34}$

Some narrowing of the social bandwidth to focus on city tradesmen is apparent here, but the song omits any allusion to the seasickness that usually characterized representations of the hoy, perhaps because of the potential for vulgar humour that it could arouse.

Charles Dibdin's song on the 'Margate Hoy' draws on well-established visual types, and develops out of and draws on the tradition of caricature prints, as much as theatrical and textual sources. Caricatures in print-shop windows and on song sheets such as those produced by Fores and Laurie and Whittle spoke to the kind of wide audience Dibdin was keen to address in print if not in person. Like Dibdin's work, this print tradition displayed its characters in comic situations often involving some degree of caricature. It was a humorous tradition that was, in Anthony Pasquin's terms, vulgar and low, but it was not degrading or savagely satirical. It was a humour adapted to the articulation or representation of aspects of the lives and perhaps sentiments of people who might otherwise not have been seen or heard.

34 [Thomas Dibdin], 'Song (Margate Hoy-Man.)', verse 2, in Songs, Chorusses, \& c c. in the New Pantomime of Harlequin's Tour; or, The Dominion of Fancy. As Performed at the Theatre-Royal, Covent Garden (London, 1800), 9. 


\title{
Interlude 3
}

\section{Dibdin and John Raphael Smith Print Culture and Fine Art}

\author{
Nicholas Grindle
}

The 1790s witnessed a minor boom in 'posture' prints of subjects taken from Charles Dibdin's songs. Posture prints were mezzotints measuring roughly $14 \times 10$ inches and advertised for sale in print-shop windows for 1 s. uncoloured or 2 s. coloured. ${ }^{1}$ In the early 1790s, printmakers in the City of London issued cheerfully coloured pictures of subjects drawn from songs performed by Dibdin in his entertainments in the Lyceum theatre: 'The Greenwich Pensioner', 'The Lamplighter', 'My Poll and my Partner Joe' (Figure I3.1), 'The Elopement' (Figure I3.2), and 'Poor Jack'. ${ }^{2}$ Such songs would constitute a major but feasible luxury for a skilled labourer such as a coachman with an income of 15 to 20 s. per week. ${ }^{3}$

The images were accompanied by a few lines from the key verses and aimed to reproduce the broad humour and vivid characterizations that made the songs so popular. The prints remained popular, being reissued (as was common practice) and also appearing in other forms such as on earthenware. ${ }^{4}$ Dibdin had extensive connections to this world of print publishing, especially through his relationship with the publisher Samuel William Fores, as discussed by David O'Shaughnessy in Chapter Four of this volume. Meanwhile, Harriet Guest's essay in Chapter Eight of this volume shows that graphic humour such as that sold by Fores was both a source of material for Dibdin as well as a means of embellishing his own song sheets.

1 For 'posture' prints, see Sheila O'Connell, 'Humorous, Historical and Miscellaneous: Mezzotints, One Shilling Plain, Two Shillings Coloured', Publishing History 70/1 (2011): 83-100.

2 'Poor Jack' was the subject of two posture prints in 1790, the first issued by Robert Sayer (BM 2010,7081.3129), the second by Carington Bowles II and Samuel Carver (BM 1935,0522.1.34). The other prints include: 'My Poll and my Partner Joe', Robert Sayer, 1790 (BM 1877,0113.162) and reissued by James Whittle and Richard Holmes Laurie, 1794 (National Maritime Museum PAF4034); 'The Greenwich Pensioner', Carington Bowles after Robert Dighton, 1790-1 (BM 1935,0522.1.35); 'The Elopement' (from The Watchman), J. Coard, 1795 (BM 2010,7081.993); and 'The Lamplighter', Carington Bowles after Robert Dighton, 1790 (BM 1935,0522.1.36).

3 For prices and wages, see O'Connell, 'Humorous', 88-9; Marcia Pointon, 'Portrait Painting as a Business Enterprise in London in the 1780s', Art History 7 (1984): 187-205.

4 Stella Beddoe, 'Charles Dibdin and the Apotheosis of Jack Tar', in Amanda Dunsmore (ed.), This Blessed Pot, This Earth: English Pottery Studies in Honour of Jonathan Horne (London: Paul Holberton Publishing, 2011), 108-12. 

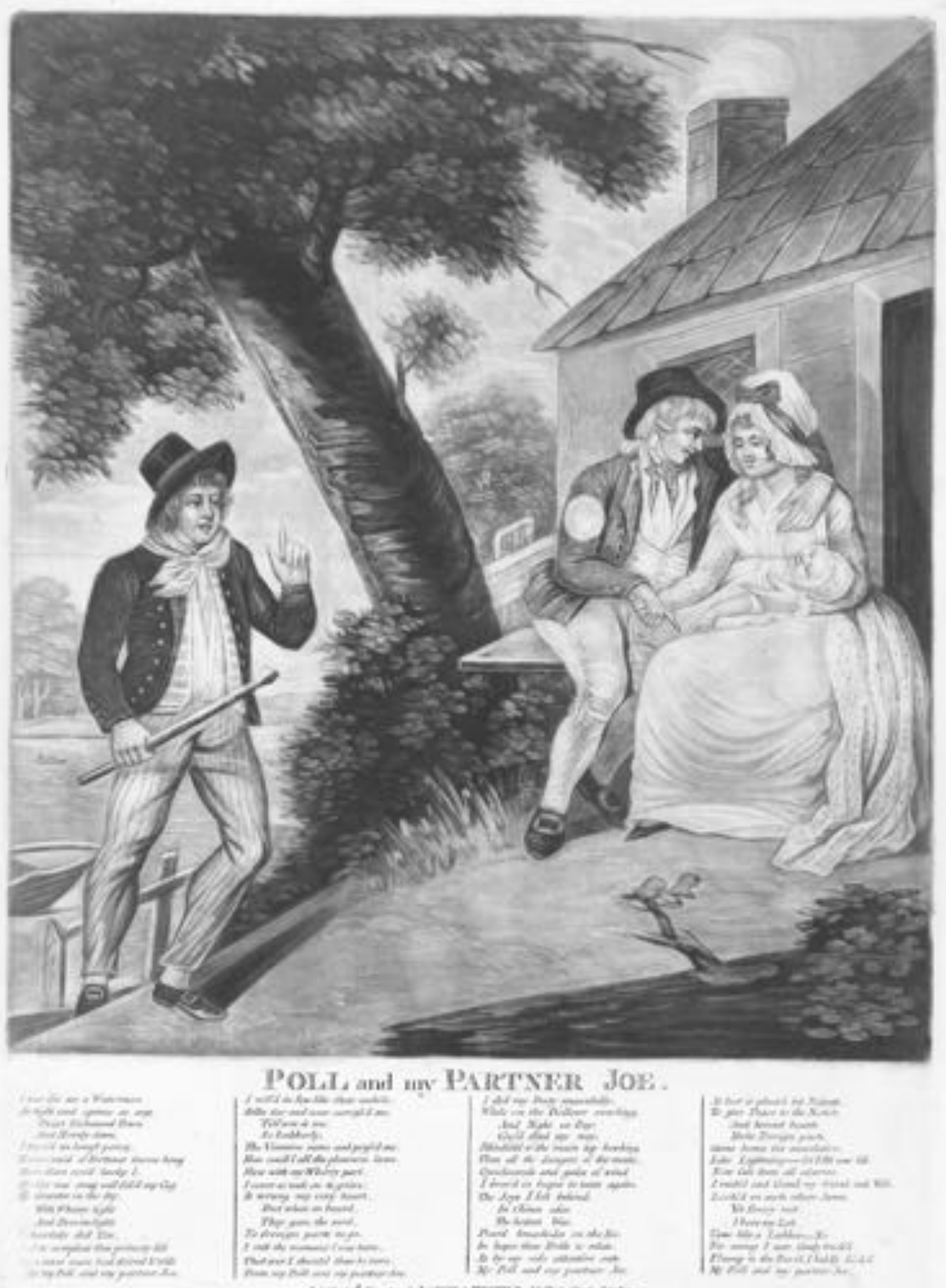

Figure I3.1. 'Poll and my Partner Joe'. London, 1794. Mezzotint, $36.7 \times 27 \mathrm{~cm}$. Courtesy of the National Maritime Museum.

Posture prints were produced in large numbers and for a relatively short time and so help to define the period, but this interlude will suggest that the more sophisticated and expensive prints after Dibdin's songs are just as important in helping us gain a rounded understanding of his world. Attention to high-art representations of 


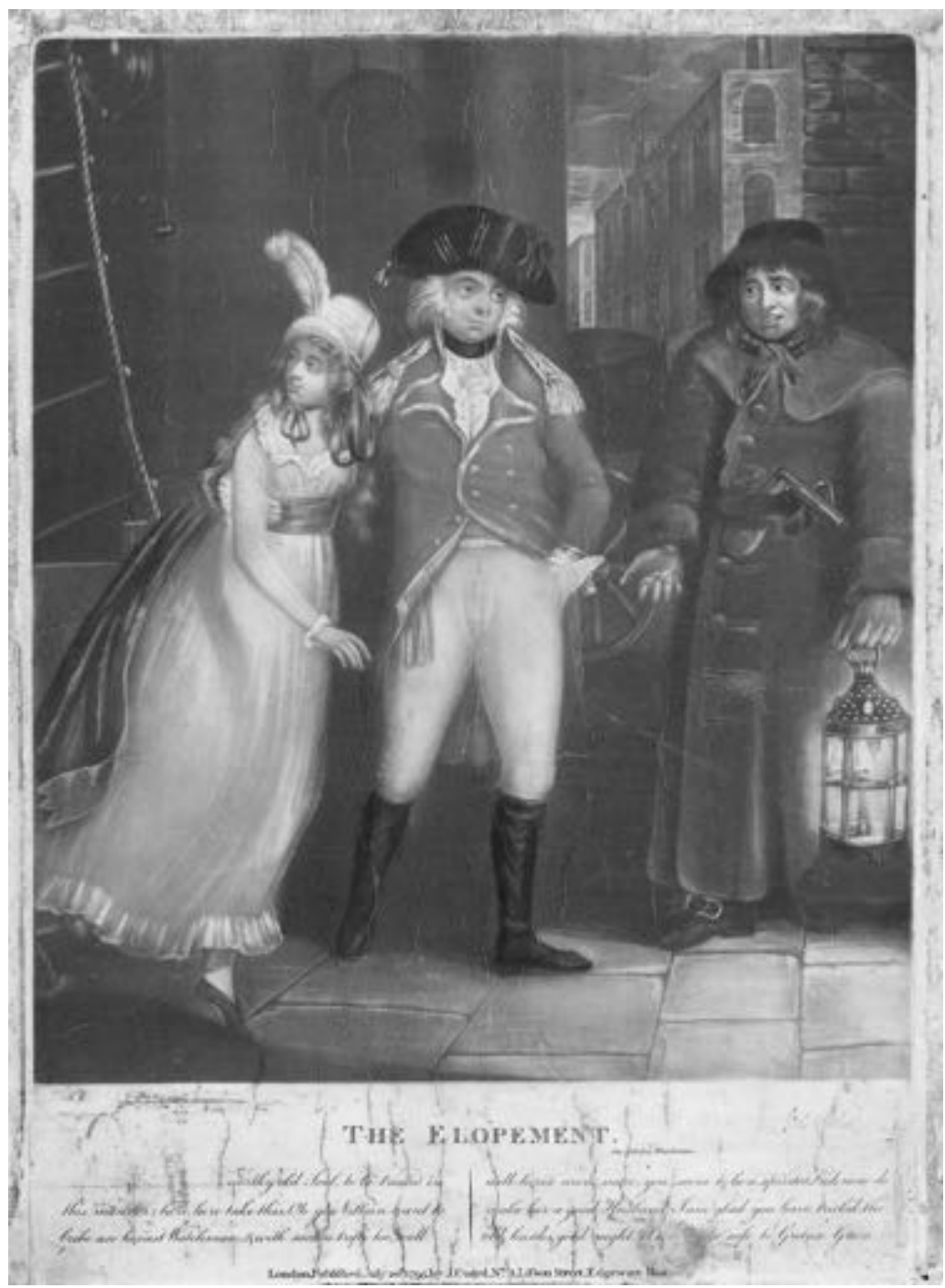

Figure I3.2. Anon., The Elopement, London, 1795. Hand-coloured mezzotint, $35 \times 24.5$ $\mathrm{cm}$. Courtesy of the Trustees of the British Museum.

Dibdin's songs is important for a number of reasons. It reminds us that subjects from Dibdin's work were popular with the higher echelons of late Georgian society as well as with those in the City, and at the same time too. By looking at how Dibdin's subjects were adapted we can also see that his songs, as well as being the subject of high art, were also transformed and parodied by the artists and the people who bought the prints. Into this conversation piece we can insert Dibdin himself and get a better sense of the people with whom he mixed and the context in which 
professional aspirations were sketched out and executed. In particular, I shall focus on three sets of prints after paintings by George Morland, published between 1789 and 1791, to explore the workings of sociable behaviours and networks of professional gentlemen. One set was a pair titled 'The Contented Waterman' and 'Jack in the Bilboes', showing scenes taken from Dibdin's song 'My Poll and My Partner Joe' (see Figures 8.11 and 8.12 for illustrations). These engravings were preceded by a set of six prints called Laetitia, which form a narrative to 'represent the progress of a young female, from a state of innocence in the country, through successive scenes of depravity and distress, till she is at last received penitent by her parents' (see Figure I3.3). ${ }^{5}$

Both sets were followed by The Deserter, a quartet of plates that appeared in 1791. Unlike the posture prints sold by City print-sellers, the mezzotint and stipple engravings done after Morland's work were published from fashionable addresses in the West End and 'bought by distinguished connoisseurs' at home and abroad. ${ }^{6}$ They were also expensive: Laetitia cost $£ 25 \mathrm{~s}$. for the set of six, uncoloured and unframed, and the Deserter $£ 2$ 2s. for the set of four. In other words each set was more than twice the weekly income of the coachman who transported Laetitia and her officer away from her parents' home in the dead of night. ${ }^{7}$

Laetitia was based on designs painted by Morland for John Raphael Smith, a wellconnected printmaker who published a wide range of portraits and subject pictures after leading artists, as well as many of his own compositions. The six prints are similar in format to a posture print but in stipple engraving rather than mezzotint, which has the same tonal range but a finer appearance, as can be seen by comparing Coard's mezzotint and Smith's stipple engraving treatment of elopements (Figures I3.2 and I3.3, respectively), and are slightly larger. The story is a sentimentalized version of a glee-club song, 'Beautiful Sally', first published in 1787 by the art dealer William Collins, who adapted it from Dibdin's song 'The High-Mettled Racer', which appeared in his entertainment Liberty Hall. ${ }^{8}$ The connections between Dibdin's song and Morland's adaptation can be traced through the circulation of Collins's 'Beautiful Sally', which was performed at the Anacreontic Society (who also printed it in 1790), where professional musicians such as Charles Bannister rubbed shoulders with amateur musicians such as John Raphael Smith. Bannister was a frequent performer of Dibdin's theatrical works in various venues, and gave the first performance of 'The High-Mettled Racer' at Drury Lane in February 1785. ' Bannister and

5 George Dawe, The Life of George Morland, with Remarks on His Works (London, 1807), 63.

6 Tim Clayton, The English Print, 1688-1802 (New Haven: Paul Mellon Centre for British Art, 1997), 274; see also O'Connell, 'Humorous', 92. Laetitia and The Deserter were published by John Raphael Smith in King Street, the main thoroughfare from Covent Garden to Leicester Fields. 'The Contented Waterman' and 'Jack in the Bilboes' were published by Philip Cornman just a stone's throw to the west in Great Newport Street.

7 For prices, see Smith's 1798 stock catalogue, reproduced in Ellen D'Oench, 'Copper into Gold': Prints by John Raphael Smith (1751-1812) (New Haven: Yale University Press, 1999), 259-64.

8 The ballad appeared in William Collins, The New Vocal Miscellany, or, a Fountain of Pure Harmony (London, 1787), but compare D'Oench, who states that Collins's claim to authorship is 'highly dubious', 'doubtful', and 'wholly false': D'Oench, 'Copper into Gold', 125, 145.

9 Public Advertiser (4 February 1785); Fahrner, 111. 


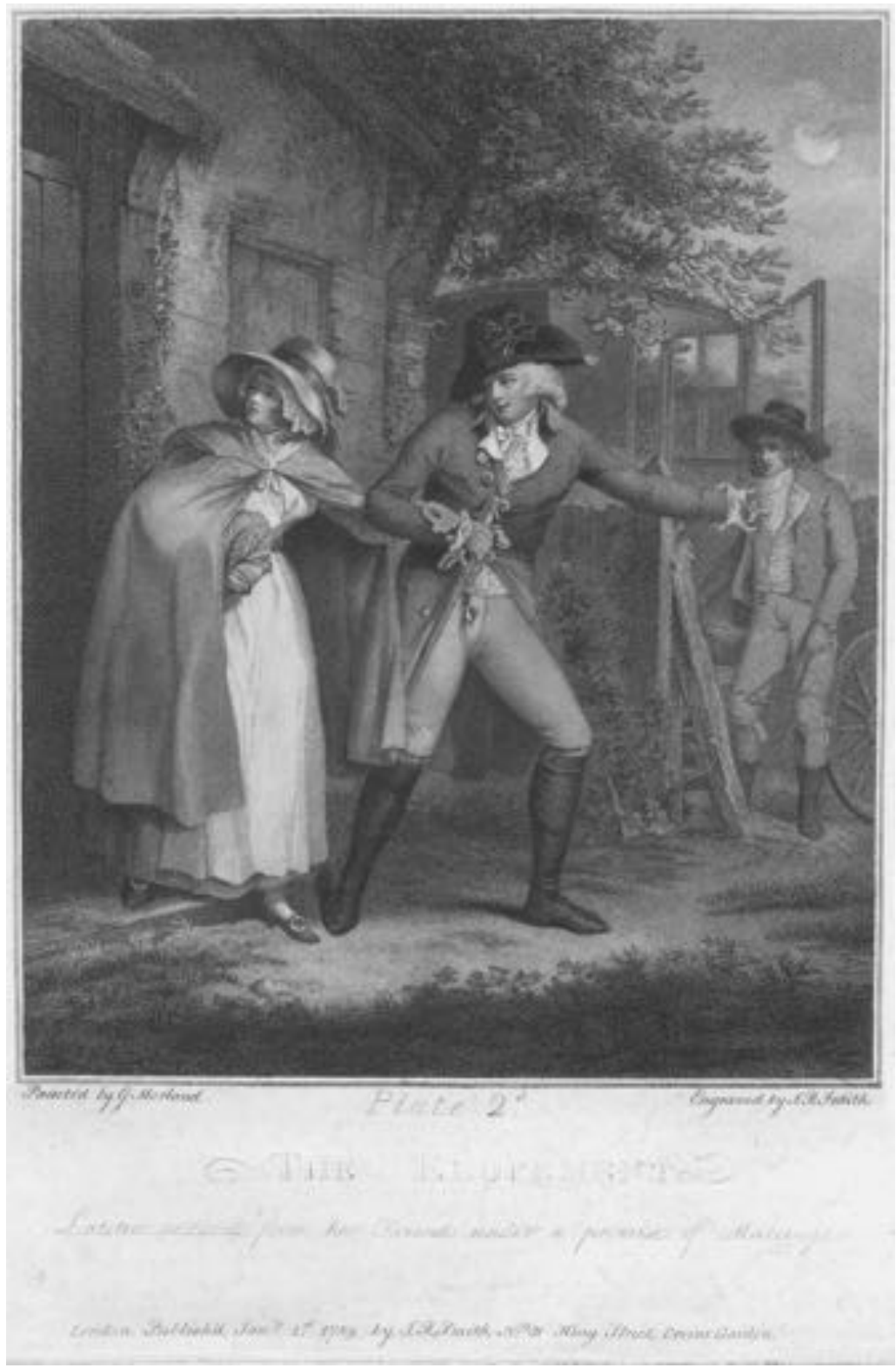

Figure I3.3. John Raphael Smith after George Morland, The Elopement, London, 1789. Stipple engraving, $47 \times 35.3 \mathrm{~cm}$. Courtesy of the Trustees of the British Museum. 
Smith frequently attended Anacreontic Society meetings, and would have known both Dibdin's song and Collins's parody. ${ }^{10}$ Smith was at this time Morland's de facto employer, and most likely suggested adapting 'Beautiful Sally', which Collins had shown him in manuscript, to Morland, who may also have known it from Collins himself, as the two had been acquaintances since the mid-1780s. ${ }^{11}$

'The Contented Waterman' and 'Jack in the Bilboes' are paintings made by Morland after Dibdin's song 'My Poll and My Partner Joe', which he probably first performed on his 'farewell tour' in $1788 .{ }^{12}$ They were engraved as a pair of extremely fine mezzotints by his brother-in-law (and Smith's former pupil) William Ward. Given that a posture print by Robert Sayers of the same subject was published at the same time as Ward's prints (1790), it is possible that the song also featured as part of Dibdin's contemporaneous entertainment The Oddities at the Lyceum. Morland's designs are much more sophisticated than Sayers's mezzotint. Like Laetitia they have ambitions to be regarded as what Collins termed 'the more exalted style of composition ... called historical painting', an aspiration signified by the representation of narrative through gesture and expression and also through references to high art, especially Dutch painting and Thomas Gainsborough's cottage-door scenes. ${ }^{13}$ Moreover, 'My Poll and My Partner Joe' is a four-verse song. Sayers's posture print, as well as Anne Dibdin's own aquatint of the song reproduced in Volume Two of The Professional Life, represents the climax in which the waterman returns from the wars to find that Joe and Poll have taken up together. But the prints after Morland's paintings only depict scenes from verses one and two. The genre of 'contrast' was popular for pictures featuring moral subjects, and Morland had already worked on a number of well-received pairs in which industry is contrasted with idleness, or cruelty with sympathy. A 'contrast' format may have been his way of instilling a measure of moral elevation into comic verse, and it also allowed him to demonstrate his mastery of contrasting passions of contentment and terror. At the same time the venture lacks Smith's business acumen, since in refusing the sentimental appeal of Smith's pictures and the cheerfulness with which Dibdin's characters tend to bear their misfortunes, the pictures become less marketable. Dibdin himself may have recognized this when he revisited the press-gang theme later in the 1790 s to give it a happier ending. ${ }^{14}$ When 'The Contented Waterman' was reissued in 1806 following Morland's early death, the publisher did not reissue its violent companion, 'Jack in the Bilboes'. ${ }^{15}$

The evidence points to Dibdin's work being interpreted, and offered to a market for sophisticated and expensive images, by a network of artists including Morland, Smith, Collins, and Ward. Dibdin and Smith were personally acquainted. Smith's

\footnotetext{
10 Julia Frankau, An Eighteenth Century Artist and Engraver. John Raphael Smith: His Life and Works (London: Macmillan \& Co., 1902), 14.

11 William Collins, Memoirs of a Picture: Containing the Adventures of Many Conspicuous Characters, 3 vols (London, 1805), 2:2, 19, 179; see also Angelo, Reminiscences, 1:243-8.

12 Life, 2:250. For the prints, see Julia Frankau, William Ward ARA and James Ward RA: Their Lives and Works (London: Macmillan, 1904), 172-3 and 217-18.

13 Collins, Memoirs, 2:43. $\quad{ }^{14}$ Life, 3:57-9.

15 See Frankau, William Ward, 172-3 and 217-18.
} 
father was a successful painter, but Smith was apprenticed to a linen draper and moved to London in 1767, having a shop in Exeter Change off the Strand. In the 1820s Henry Angelo recalled, 'It was during [Smith's] residence there, that he became acquainted with Charles Dibdin, and having then some practical knowledge of the arts, Dibdin [then at Drury Lane] advised him to sink the shop, and become a "professor and a gentleman"'. ${ }^{16}$ (By 'professor' he is most likely to have meant one who professed an art both as a living and as a gentleman.) Dibdin and Smith's acquaintance may still have been warm in 1789 when Dibdin gave his first solo entertainments in an auction-room in King Street, Covent Garden, the same street in which Smith had his shop, and where he showed paintings by Morland and his prints after them. ${ }^{17}$ It is possible that Smith was one of the 'friends' who encouraged Dibdin to persevere with solo performance and to begin publishing his own work, a move Smith himself had taken in 1781, and which he followed with a solo exhibition in Norwich in $1784 .^{18}$

We can see from the case of Laetitia that the activities of clubs played a vital role in mediating between song and print, as well as serving as a means by which singers and artists met one another. Smith was a member of the Anacreontic Society, a club for noblemen and professional singers that hosted semi-private concerts and met in the Crown and Anchor tavern, just east of Smith's shops in Exeter Change and Exeter Court, which 'contained one splendid room measuring no less than $84 \mathrm{ft}$ by $35 \mathrm{ft}$ ' where a large company could meet. ${ }^{19}$ Dibdin himself composed many songs, and, as we have already seen, these were adapted and given new words by amateurs such as Collins. While there is no evidence that Dibdin attended meetings of the Anacreontic Society, he circulated in the same milieu; his songs were well known there, and he performed at the same venue in 1807 at a Royal Academy birthday dinner, where he 'much pleased [the Academicians] with humorous songs' ${ }^{20}$

For his part Dibdin was an accomplished draughtsman, as testified by his accomplished pen-and-wash landscape drawings in the contemporary picturesque style, such as his Church at Lyme Regis (see Figure I3.4). ${ }^{21}$ Henry Angelo's comment that Dibdin had 'some practical knowledge of the arts' is borne out by these drawings; he may have been a member of a sketching club such as the Jack Harris tavern club, hosted by the West End frame-maker John Harris, which Smith also attended. ${ }^{22}$ Shortly before The Professional Life appeared, Dibdin published his Observations on a Tour, 'two large and handsome quarto volumes, embellished with forty views and twenty vignettes'. In the 'Advertisement' which prefaced the volumes Dibdin exclaims, 'Painting, which had been only my private

16 Angelo, Reminiscences, 2:241.

18 D'Oench, 'Copper into Gold', 150.

17 Life, 3:2.

19 E. Beresford Chancellor, Annals of the Strand (London: Chapman and Hall, 1912), 333; see also Ian Newman's blog on alehouses and political space (accessed 6 July 2015): http://www. 1790salehouse.com. For Smith's membership, see Frankau, John Raphael Smith, 17.

${ }^{20}$ Joseph Farington, The Diary of Joseph Farington, ed. Kathryn Cave, 16 vols (New Haven: Yale University Press, 1982), 8:3059, 5 June 1807.

21 e.g. BM 1876,0708.2372; BM 1876,0708.2373.

22 Frankau, John Raphael Smith, 17, and Walter Thornbury, The Life of J. M. W. Turner, 2 vols (1862, repr. Cambridge: Cambridge University Press, 2013), 1:108. 


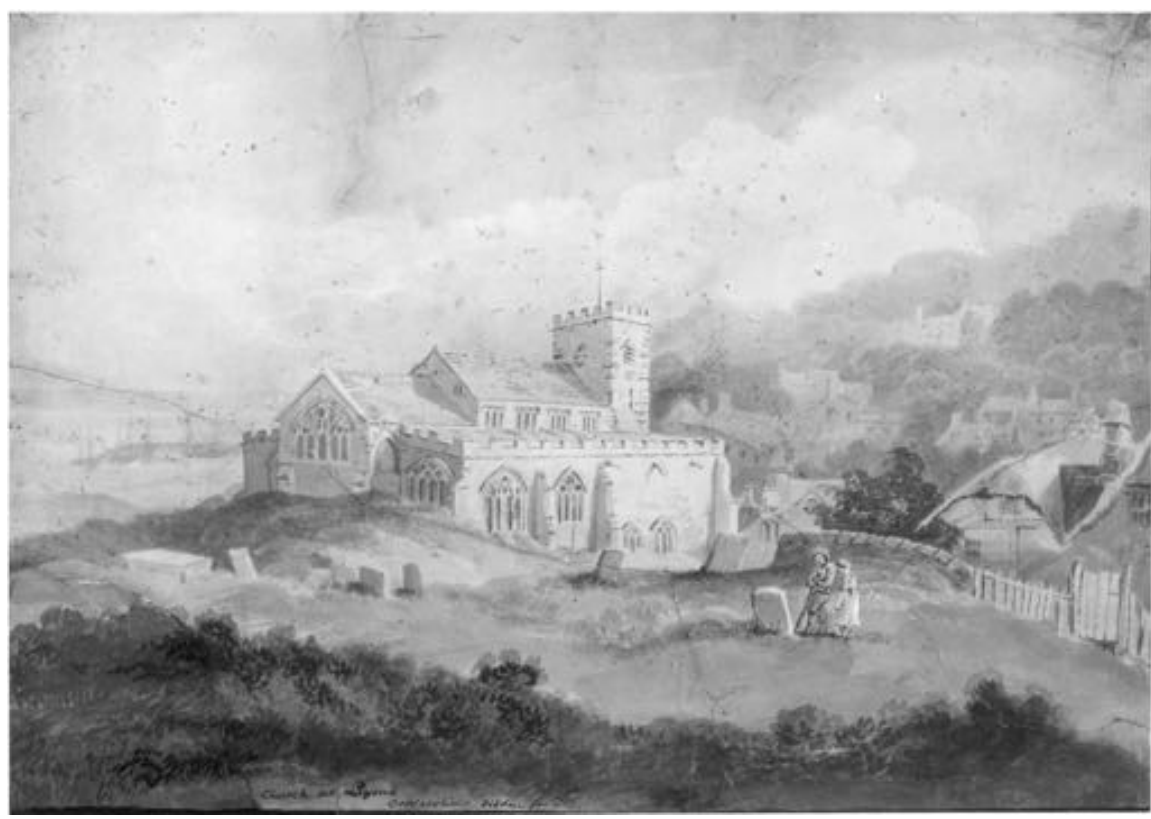

Figure I3.4. Charles Dibdin, Church at Lyme Regis, n.d. Brush drawing in grey wash on paper, $27.1 \times 40.4 \mathrm{~cm}$. Courtesy of the Trustees of the British Museum.

amusement, out of devotion to the public, I have in this instance made one of my professions. ${ }^{23}$ In other words his profession of painting was a public extension of his private character. Amateur drawing, as contemporary guides pointed out, was the exemplary private medium, and it was in the context of sketching clubs and the taking of a picturesque tour that the profession of an art agreed with the private status of a gentleman, something that Dibdin was no doubt eager to advertise. But the associations may reach further than that. Dibdin's views and vignettes conform in every way to the prescriptions laid down in manuals such as Rudolph Ackermann's Lessons for Beginners in the Fine Arts (1796). Ackermann was proprietor of a large shop called 'The Repository of Arts' at 101 Strand, opposite the Lyceum and a few yards west of the Royal Academy's home in Somerset House. ${ }^{24}$ Like Dibdin's own shop and theatre in Leicester Place, and Smith's shop and gallery in King Street, the Repository disguised its commercial functions in the garb of private leisure through the addition of a drawing school, a library, and (by 1801) a small gallery. ${ }^{25}$ Aquatint, the method used by Anne Dibdin to turn her father's tinted

23 Observations.

${ }^{24}$ For more on Ackermann's 'Repository', see Ann Bermingham, Learning to Draw: Studies in the Cultural History of a Polite and Useful Art (New Haven and London: Yale University Press, 2000), 127-43.

25 These parallels may have resonated in 1811 when Ackermann reissued Smith's Laetitia in a new series. 


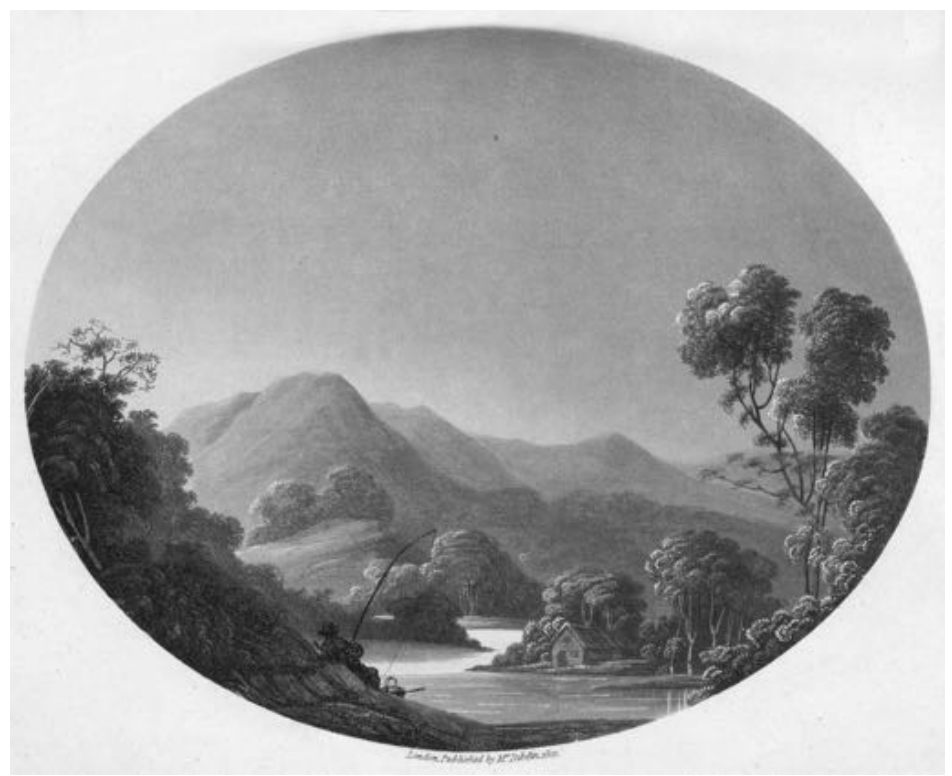

Figure I3.5. Anne Dibdin after Charles Dibdin, 'Approach to Langholm', London, 1801. Aquatint. From Observations. (C) The British Library Board, 190.c.4-5 vol. 1, facing page 326

drawings into print (see Figure I3.5), was the same method used by Ackermann and other publishers of 'progressive' drawing manuals to demonstrate the process of composing a landscape drawing. ${ }^{26}$ Publishing the aquatints in Observations on a Tour helped align the character of Dibdin's shop and theatre with the kind of venture promoted so successfully by Ackermann. It also formed part of Dibdin's broader and more long-standing claim to be a professional but leisured man of letters modelled by figures such as Charles Burney, as discussed in Chapter One of this volume.

For Dibdin and Smith clubs were an important medium for professional and social affiliation. For models of professional success they had David Garrick and Sir Joshua Reynolds, first President of the Royal Academy, with whom they had, respectively, close working relationships. While it is difficult to know how clubbable Dibdin really was-The Professional Life says little about informal friendships, and he is quick to distinguish his own conduct from the masculine world of drinking, rural sports, and glees that inform his songs-we should note that male conviviality took a wide range of forms, and Burney, Garrick, and Reynolds's 'Club', and indeed the Royal Academy itself, had as good a claim as any to embody the ideal of sober male companionship adumbrated by Joseph Addison in the Spectator. ${ }^{27}$ Dibdin's self-fashioning as a gentleman-professor of picturesque

26 Bermingham, Learning, 165-7.

27 Life, 1:8. For a more detailed discussion of Dibdin's alignment with the Spectator, see Chapter Four of this volume. 
scenery speaks to the explicitly clubbable male world of the Georgian theatre revealed in The Professional Life, but also to the more conspicuously female character of the leisured classes at the turn of the century. If, as Ann Bermingham has suggested, these two spheres competed for cultural authority around 1800, ${ }^{28}$ we should also note that neither would question the broad truth of Dibdin's assumption that the summit of professional achievement was to be known as a 'professor and a gentleman'.

In this context, it is unsurprising that art had high ambitions. Different attempts were made in the eighteenth century to show how art could make people virtuous, and sociability was a key feature in most theories. ${ }^{29}$ Clubs and commerce served as a means to transcend local associations and personal interest through cultivation of private character, which is precisely what art in its highest eighteenth-century form, the painting of exemplary virtue, also claimed to do. Given this association of private character and professional ambition, we should not be surprised if a glimpse of private life sheds new light on the structure and ambitions of professional activity, as suggested by Dibdin's advice to Smith to become 'a professor and a gentleman'. Dibdin's shop in Leicester Place had the same refined character as Smith's shop in King Street. In fact the situation of their shops, performances, exhibitions, and clubs along the principal thoroughfares of the West End-the Strand, King Street, Leicester Square-helps us see that claims to gentlemanly and professional status were facilitated by local contacts, but at the same time had to divest themselves of any local character. In this context, Dibdin's exasperated 'I grew most intolerably sick of a traffic with music-shops' may be more than simply a metaphor, since it reveals a concern that the very topography of London and the sinews of its commerce was antithetical to the private character of a professor and gentleman, a combination whose best spatial analogy is the picturesque tour. ${ }^{30}$

28 Bermingham, Learning, $127 \mathrm{ff}$.

29 See especially Andrew Hemingway, 'The "Sociology" of Taste in the Scottish Enlightenment', Oxford Art Journal 12/2 (1989): 3-35, and David H. Solkin, Painting for Money: The Visual Arts and the Public Sphere in Eighteenth-Century England (New Haven and London: Yale University Press, 1992).

30 Life, 3:8. 


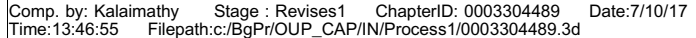

OUP UNCORRECTED PROOF - REVISES, 7/10/2017, SPi 


\section{PART III}

\section{NINETEENTH-CENTURY TRANSITIONS}



\begin{tabular}{|l} 
Comp. by: Kalaimathy Stage : Revises1 ChapterID: 0003304485 \\
Time:13:57:05 Filepath:c:/BgPr/OUP_CAP/IN/Process1/0003304485.3d
\end{tabular} Date:7/10/17

OUP UNCORRECTED PROOF - REVISES, 7/10/2017, SPi 
9

\title{
The Changing Theatrical Economy Charles Dibdin the Younger at Sadler's Wells, 1814-19
}

\author{
Susan Valladares
}

Charles Isaac Mungo Dibdin (Charles the Younger) managed and wrote for Sadler's Wells Theatre between 1800 and 1819. He was the eldest son of Charles Dibdin and Harriet Pitt, an actress. His brother, Thomas Dibdin, would also make a name for himself as an actor, playwright, and manager, as discussed by Jim Davis in Chapter Ten of this volume. In the early nineteenth century, frequent comparisons were made between the careers of Charles Dibdin the Elder and his two sons, who, despite enjoying professional successes in their own right, were generally compared to their father at a disadvantage (their illegitimacy — as children born out of wedlock-being seemingly reflected in their perceived failure to match his achievements).

This chapter focuses on Charles the Younger's final years as manager of Sadler's Wells-a remote venue known as 'the country theatre', whose location in Islington meant that there was 'scarcely a House' nearby until the late 1810s. ${ }^{1}$ But Sadler's Wells was also one of London's oldest and most successful minor theatres. Charles the Younger was its manager for nineteen years and six months but left reluctantly thereafter, bitterly reflecting that although the theatre had been his 'pet child', 'pet children do not always turn out the most filially affectionate' (Memoirs, 125). By examining the possible reasons for his withdrawal, this chapter begins to identify the pressures attendant upon the theatrical economy during the early decades of the nineteenth century. It focuses on the range of topical entertainments presented at Sadler's Wells between the proclamation of peace on 20 June 1814 (the date Charles the Younger singles out in his Memoirs as marking the beginning of his theatre's decline) and 12 April 1819 (the start of his final season as manager). From this opening consideration of the generically heterogeneous performances at Sadler's Wells, the chapter then turns to Charles the Younger's Young Arthur; or, The Child of Mystery: A Metrical Romance (1819), which it reads as another index

1 Charles Isaac Mungo Dibdin, Memoirs of Charles Dibdin the Younger, ed. George Speaight (London: Society for Theatre Research, 1956), 41. The Memoirs were composed in 1830 but first published (in this abridged form) in 1956. Further references are given after quotations in the text. 
of the changes to the cultural economy of the early nineteenth century. This chapter thus aims to add its own inflections to the political, aesthetic, and commercial questions raised by other contributors to this volume, and implicitly to provide a longer chronological perspective from which to view the career of Charles Dibdin the Elder.

\section{SADLER'S WELLS POSTWAR}

Charles the Younger took up management of Sadler's Wells Theatre in 1800. Two years later he and Thomas Dibdin became shareholders (his brother investing $£ 1,400$ in the purchase of a quarter-share). ${ }^{2}$ In 1804 a water tank sourced from the nearby New River was installed on stage, and another smaller tank placed within the roof, to enable waterfall effects. The Siege of Gibraltar (1804) was the first production to benefit from these innovations. This nationalist entertainment, complete with ships built to scale by shipwrights from the Woolwich dockyard and the engagement of young boy actors to sustain the illusion of distance, represented such a departure from usual staging practices that Charles the Younger confidently described his 'coup d'oeil as a spectacular 'coup de theatre' (Memoirs, 62). Charles the Younger was here building upon the 'innovative, varied, entertaining' programme that Michael Burden, in tracing Charles the Elder's fortunes at the Royal Circus, has defined as foundational to the success of the minor theatres. ${ }^{3}$ But whereas Charles the Elder would be most readily remembered for his sea songs, Charles the Younger would win renown for his staging of sea battles: thanks to its water tanks, Sadler's Wells became adept at reproducing, in the words of Jane Moody, 'an aquatic theatre of war' that enticed audiences from all parts of the city. ${ }^{4}$

In the years after the Napoleonic Wars, Sadler's Wells was, however, a theatre in decline. Postwar economic and social distress reduced the demand for theatregoing more generally, while the establishment of new London theatres, such as the Coburg, which opened on 11 May 1818, made the situation even worse. The fierce competition between the old and new minor theatres put direct pressure, for instance, on Thomas Dibdin's management of the Surrey. ${ }^{5}$ At Sadler's Wells, the situation was further complicated by a series of internal problems. By the late 1810 s, audiences had become over-familiar with the effects of the main water tank; contractual disputes resulted in the absence of the hitherto regular performer Joseph Grimaldi-the celebrated Clown of English pantomime-for the entire 1817-18 season; while changes to the theatre's managerial hierarchy fostered feelings of resentment and alienation. It is interesting, therefore, that in his Memoirs, Charles the Younger should have allowed so much to rest upon his belief that 'theatres (in London, at least) prosper most during War'. 'It is a fact', he

\footnotetext{
2 John Russell Stephens, 'Dibdin, Thomas John (1771-1841)', ODNB (accessed 4 April 2015), http://www.oxforddnb.com/view/article/7589?docPos=2.

3 Chapter Three of this volume. $\quad{ }^{4}$ Moody, Illegitimate Theatre, 28.

5 Stephens, 'Dibdin, Thomas John'.
} 
laments, 'that immediately previous to the short Peace of Amiens, Sadler's Wells was crowded every night; but as soon as the Peace was announced, our receipts suddenly fell off to a very serious degree, and continued in that reduced state, till the war recommenced, and then they recovered their former amount' (Memoirs, 119). Although he goes on to concede that 'many reasons have been given for such occurrences', his analysis ends here, lest it fail to appear 'thoroughly intelligible to others', and because he remains uncertain as to 'whether or no it is worth enquiring into at all' (119). While Charles the Younger identifies a sharp decline in profits during the fourteen months that marked the Peace of Amiens, he describes, significantly, only a gradual decline in theatrical fortunes following Napoleon's abdication (119).

Indeed, the years 1814 to 1817 were far from complete failures: Sadler's Wells still made a profit and several new entertainments attracted public notice. These included Charles the Younger's aquatic dramas The Two Caliphs; or, The Genii of the Waters (11 April 1814) and The Corsair (18 July 1814). The latter boasted especially impressive scenic effects; its finale re-enacting 'a conflagration' of the Castle of Seyd that, being reflected upon the water, 'made the whole Stage appear as if it were on fire' (Memoirs, 109). ${ }^{6}$ Based on Byron's bestselling poem, Charles the Younger's The Corsair partook of what would become an especially voguish trend in the late 1810s and 1820s - the adaptation of popular poems and novels for the stage. Byron's oriental poem had been an immediate bestseller and would, in fact, prove to be one of the most successful individual long poems of the Romantic period (enjoying sales of an estimated 25,000 copies; whereas, by comparison, Childe Harold's Pilgrimage, A Romaunt (1812) sold approximately 13,750 copies). ${ }^{7}$ Adaptations would also characterize the repertoire at the Adelphi (formerly Sans Pareil) Theatre, which responded to popular demand for 'The Great Unknown' with Ivanhoe; or, The Saxon Chief (27 January 1820) and Kenilworth (8 February 1821 ), and at the Royal Circus, where Thomas Dibdin produced stage versions of Walter Scott's Montrose and The Bride of Lammermoor less than a fortnight after their publication. ${ }^{8}$

These stage adaptations tended to be only loosely based upon the original literary texts; The Corsair was no exception, with Charles the Younger's desire to play to the strengths of his company and provide a more arresting finale resulting in significant deviations from his source narrative. His 1817 production of The Gheber; or, The Fire Worshippers took similar liberties with Thomas Moore's Lallah Rookh, another bestseller. Orientalism was by then a recognizable feature of the dramatic repertoire, both patent and minor. As Daniel O'Quinn has convincingly argued, eighteenth-century representations of Islamic society on

6 Charles Isaac Mungo Dibdin, Songs, or with a Description of the Scenery in the New Aqua-Drama called 'The Corsair' (London, 1814), 24.

7 These figures, as cited by William St Clair, exclude 'collected editions, imports and piracies'. William St Clair, The Reading Nation in the Romantic Period (Cambridge: Cambridge University Press, 2004), 218.

8 William Knight, A Major London Minor: The Surrey Theatre 1805-1865 (London: Society for Theatre Research, 1997), 24. 
the London stages tended to be strongly politicized-a means, especially, of testing 'the limits of monarchical power'. ' Within this context, O'Quinn describes Charles Dibdin the Elder's and Edward Thompson's The Seraglio (Covent Garden, 1776) as a play 'obsessed with the space of the harem first as a site of sexual fantasy and second as a symptom of political lassitude'. ${ }^{10}$ Claire Mabilat's distinction between exoticism as 'an artistic tool' and orientalism as a concept charged with defined 'cultural and/or political agendas' is thus particularly useful. ${ }^{11}$ At Sadler's Wells, exoticism and orientalism tended to be equally present in entertainments that had clearly been written to capitalize upon the theatre's capacity for impressive stage effects, but that also sought to go beyond the spectacular by tapping into the public's wider curiosity for Eastern customs and politics.

\section{THE EXOTICIZED CITY}

At Sadler's Wells, so pronounced was the demand for spectacular effect that the theatre's main scene painters, Luke Clint and Robert Andrews, struggled to keep up. In 1814 they were joined by John Henderson Grieve, who also worked as a scene painter for Covent Garden. ${ }^{12}$ Both pantomimes of the $1815-16$ seasonMermaid; or, Harlequin Pearl Diver (27 March 1815) and Harlequin Brilliant; or, The Clown's Capers (3 July 1815) — and the revived aqua-drama of Kaloc; or, The Slave Pirate (first staged in 1813) called for impressive backdrops. Indeed, so complex were the scene changes for Harlequin Brilliant that Charles the Younger inserted two songs between scenes thirteen and fourteen in order to buy time for the technicians to realize the elaborate transformation of the 'Pavilion at Brighton' to a scene set 'on real water' depicting the launch of HMS Britannia from a British dockyard. ${ }^{13}$ The fact that this was not even the pantomime's concluding scene is all the more significant in light of David Mayer's salient reminder that at Sadler's Wells special effects tended to be reserved for the grand finale. ${ }^{14}$ While other theatres, such as Drury Lane, necessarily compensated for the absence of a strong Clown by investing heavily in scenic effect, Grimaldi's regular engagement at Sadler's Wells meant that its pantomimes could privilege the harlequinade's characteristic chase and pursuit. But by 1815 spectacle was such an integral part of the theatrical experience that not even the pantomimes at Sadler's Wells dared to minimize it. Not all audience members of the minor theatres were fully literate,

\footnotetext{
9 Daniel O'Quinn, 'Theatre, Islam, and the Question of Monarchy', in Swindells and Taylor, Handbook of the Georgian Theatre, 638-54, 639.

10 O'Quinn, 'Theatre', 646.

11 Claire Mabilat, Orientalism and Representations of Music in the Nineteenth-Century British Popular Arts (Farnham: Ashgate, 2008), 7.

12 Sybil Rosenfeld, 'A Sadler's Wells Scene Book', Theatre Notebook 15/2 (1960-1): 57-62, 59.

13 Charles Isaac Mungo Dibdin, Songs, \& $c$ in the Pantomime called Harlequin Brilliant; or, The Clown's Capers' (London, 1815), 8-9.

${ }_{14}$ David Mayer, Harlequin in His Element: The English Pantomime, 1806-1836 (Cambridge, MA: Harvard University Press, 1969), 35.
} 
but the entertainments on offer catered to degrees of visual and musical literacy that offered important compensation for this.

A surviving scene book, detailing the various set designs that Andrews, Grieve, and Clint produced for Sadler's Wells, testifies to a commitment to scenic novelty across the genres. ${ }^{15}$ The book includes seven scenes from the melodrama Iwanowna; or, The Maid of Moscow (13 May 1815), which required the collaboration of the three principal artists for the recreation of extravagant indoor and outdoor spaces. In preparation for the finale Andrews constructed 'A Setting Scene. Transparent Back'd Working Roller Behind Burning Moscow' (no.34) whose effects Charles the Younger would recall as nothing short of 'electrical' (Memoirs, 116). The play then concluded in a 'superb hall' (no.41), also prominently advertised in the playbills. The scene book's inclusion of only a partial sketch of the hall suggests that this final scene alone consisted of various intricately linked parts.

The Sadler's Wells scene book captures what Shearer West describes as 'a changing professional art world ... that saw the evolution of painting from trade to a liberal art, while scientific advances provided opportunities for new experimentation with scenic effect'. ${ }^{16}$ It also helps us identify specific geographies of production and reception since, intriguingly, some of the designs for the theatre's most elaborate pantomimes imply an interest in redirecting the gaze from scenes of foreign splendour to the capital's more familiar topography. The pantomime Mermaid, for instance, included a panoramic view of the New River Reservoir and Sadler's Wells itself as a main scene. ${ }^{17}$ The following season's Easter pantomime London and Paris; or, Harlequin Traveller (15 April 1816) took this even further by contrasting in 'alternation, the most attractive and popular scenes, and views, in each of these cities, and in their respective environs', as Charles the Younger proudly outlines in his Memoirs (116).

As the Continent reopened for travel, verisimilitude rose high on the artistic agenda. Stuart Semmel details how, in the aftermath of Waterloo, 'thousands of Britons found themselves confronted with material vestiges of Napoleon's fallen empire. They encountered portable momentos [sic]: teeth, bullets, the carriage of Bonaparte himself' 18 _ in short, miscellaneous relics of war that were sourced in Belgium and subsequently showcased in English private homes and public spaces, such as the Egyptian Hall (where Napoleon's carriage went on display in the first week of January 1816), the Waterloo Museum in Pall Mall, and the nearby Waterloo Exhibition and Waterloo Rooms. ${ }^{19}$ The entertainments at Sadler's Wells at once registered and reacted against these different kinds of postwar spectacle. After 1815,

\footnotetext{
15 See 'Sadler's Wells Scene Book', The Garrick Club, London. The book was bought at the sale of Louis Haghes's Library and Engravings on 7 August 1885 (Lot 48).

16 Shearer West, 'Manufacturing Spectacle', in Swindells and Taylor, Handbook of the Georgian Theatre, 286-303, 288.

17 Charles Isaac Mungo Dibdin, Songs, and other Vocal Compositions in the Pantomime called 'Mermaid; or, Harlequin Pearl Diver!' (London, 1815), 'Scenery'.

18 Stuart Semmel, 'Reading the Tangible Past: British Tourism, Collecting, and Memory after Waterloo', Representations 69 (2000): 9-37, 9.

19 Richard Altick, The Shows of London (Cambridge, MA: Belknap Press, 1978), 239-40.
} 


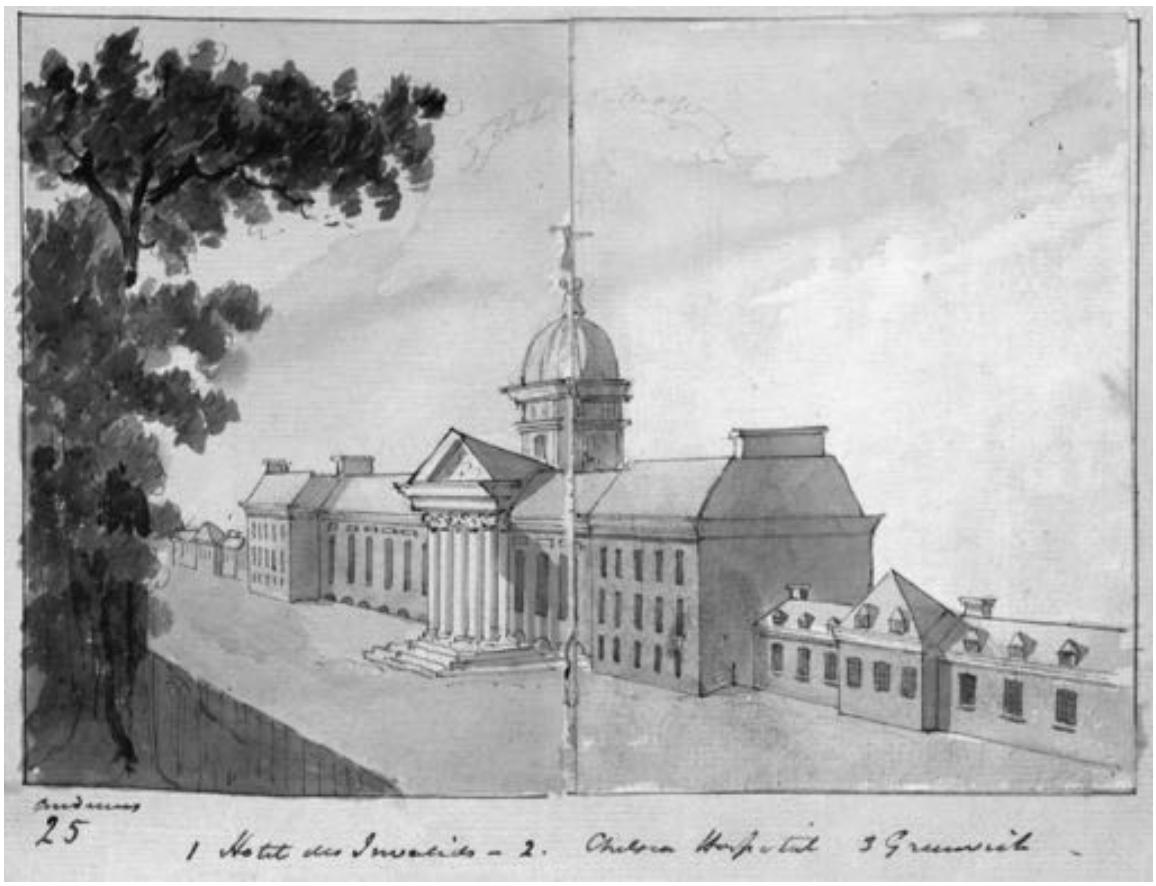

Figure 9.1. Robert C. Andrews, trick scene on flaps for the Sadler's Wells pantomime London and Paris (London, 1816), depicting Hôtel des Invalides. Pen and watercolour. From 'Sadler's Wells Scene Book'. Courtesy of The Garrick Club, London.

Charles the Younger and his team of artists would have been fully aware that audiences not only sought pleasure from, but actively scrutinized, the scenic transformations enacted by Harlequin's magic sword or bat. In the Sadler's Wells scene book, the use of paper flaps (as illustrated in Figures 9.1, 9.2, and 9.3) permitted individual scenes from London and Paris to be superimposed by as many as two or three others. It provides a compelling record of the harlequinade's movement between parallel sites in Paris and London, such as the Hôtel des Invalides, Chelsea Hospital, and Greenwich (no.25; Figures 9.1, 9.2, and 9.3), or the Hôtel des Monnaies and Bank of England (no.26).

By the 1820s, pantomimes would rely ever more heavily on the threedimensional scenic model provided by the diorama. As Mayer explains, this aimed in large part to compensate for the decline of the harlequinade following Grimaldi's reduced appearances on stage, as a result of his deteriorating health, and official retirement in $1823 .^{20}$ What is interesting about a pantomime such as London and Paris is that it suggests that in the 1810s tentative moves were already being made towards the kind of scenic narrative embodied by the diorama—even at Sadler's Wells, during a period when it was still known as Grimaldi's 'home'. 


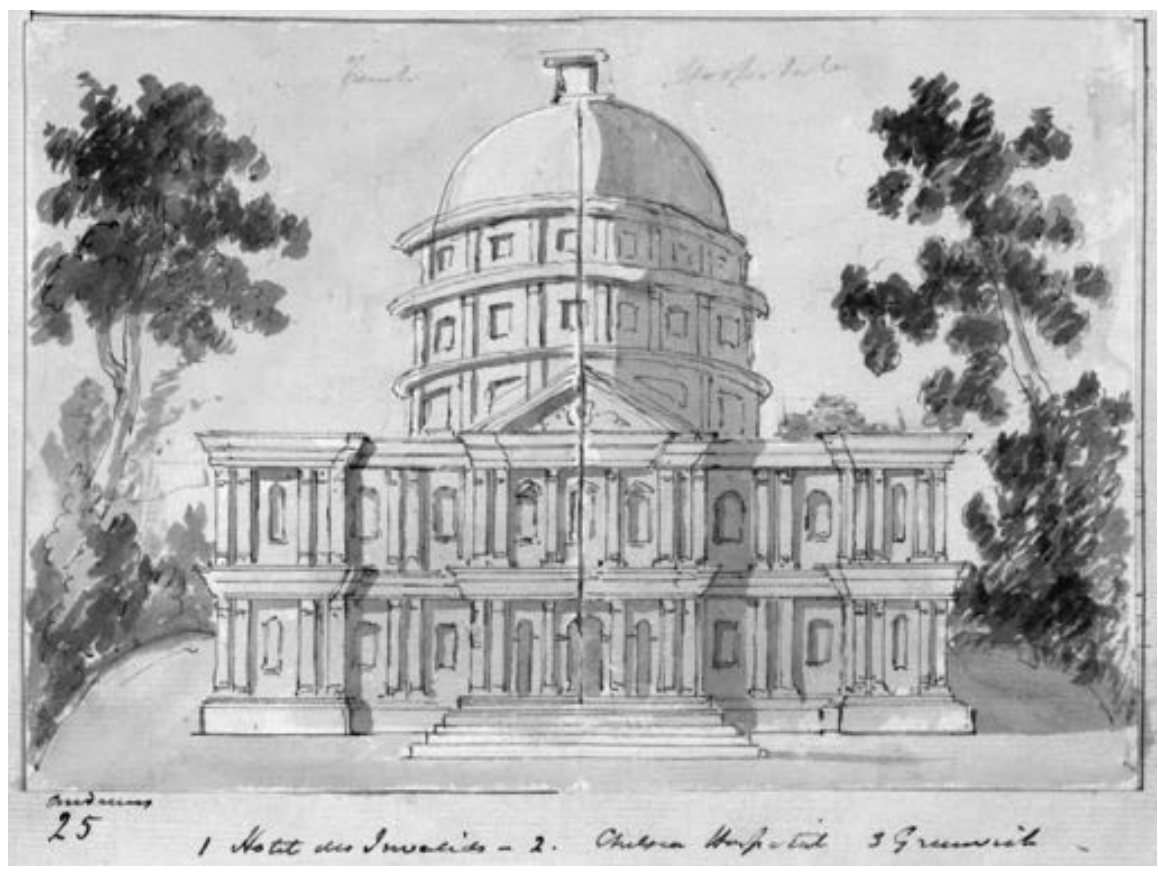

Figure 9.2. Robert C. Andrews, trick scene on flaps for the Sadler's Wells pantomime London and Paris (London, 1816), depicting Chelsea Hospital. Pen and watercolour. From 'Sadler's Wells Scene Book'. Courtesy of The Garrick Club, London.

London and Paris suggests, furthermore, that while representations of Paris clearly constituted a principal attraction for postwar audiences, the English capital was recognized as an 'exotic' site in its own right. The pantomime depended, after all, upon scenes presented in alternation, rather than consecutive sequences focused on any one locale. This structuring lends weight to what James Chandler and Kevin Gilmartin have called the phenomenon of the 'eidometropolis', borrowing the title of Thomas Girton's 1802 pictorial representation of London to describe how the Romantic city became a form of panoramic spectacle. ${ }^{21}$

The exoticization of London included, significantly, an interest in the minor theatres' specific localization within it. This was neatly exemplified by the competing responses to the first London performances of Mozart's opera Don Giovanni. As Moyra Haslett notes, in early 1818 'the [Don Juan] legend's monopoly of the theatres was complete' with 'six different productions playing simultaneously in the capital'. ${ }^{22}$ These included the Royal Circus's burlesque, Don Giovanni; or,

21 James Chandler and Kevin Gilmartin, 'Introduction', in James Chandler and Kevin Gilmartin (eds), The Romantic Metropolis, The Urban Scene of British Culture, 1780-1840 (Cambridge: Cambridge University Press, 2005), 1-41, 8.

22 Moyra Haslett, Byron's 'Don Juan' and the Don Juan Legend (Oxford: Oxford University Press, 1997), 142. 


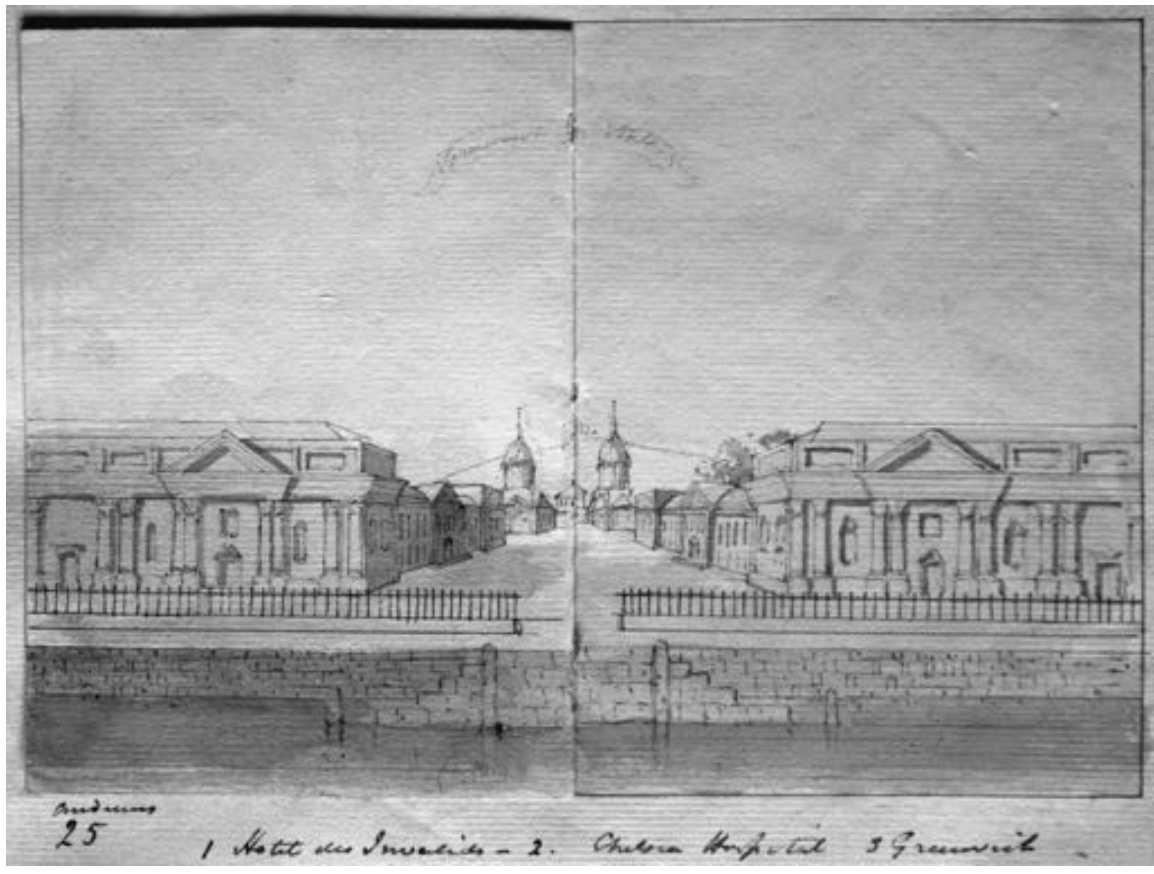

Figure 9.3. Robert C. Andrews, trick scene on flaps for the Sadler's Wells pantomime London and Paris (London, 1816), depicting Greenwich. Pen and watercolour. From 'Sadler's Wells Scene Book'. Courtesy of The Garrick Club, London.

A Spectacle on Horseback! (26 May 1817), which enjoyed more than one hundred performances, ${ }^{23}$ and the Olympic Theatre's Don Giovanni in London, which had premiered on 26 December 1817. The latter exploited advances in lighting techniques that promised not only visually impressive but also satirically incisive representations of an assemblage of places within the capital. These were listed on the playbills as 'St Giles's (by gas light)', 'Westminster Hall (in a new light)', 'Interior of the King's Bench (in its true light)', 'Exterior of the Insolvent Court (by sky light)', 'Charing Cross (by a blue light)', and Drury Lane's 'Grand Saloon (by a fan light)'. ${ }^{24}$ Meanwhile, the Royal Circus's playbills stated that Thomas Dibdin's production of Don Giovanni would include scenes in or near Seville but also '(by way of a Pictorial Episode) a fine scene of Blackfriars Bridge taken in the Circus'. ${ }^{25}$ In the earlier pantomime of The Dog and Duck; or, Harlequin in the Obelisk (1816) the Circus had already presented a variety of new London scenes, including a 'View from the Obelisk, looking towards the Surrey Theatre' and the 'Interior of the Royal Circus'. ${ }^{26}$ This fascination for the sites of London attests to a modern understanding of the metropolis as 'at once capital to the provinces and

23 Knight, A Major London Minor, 24.

25 Royal Circus Playbill (14 May 1817).
24 Olympic Theatre Playbill (26 January 1818).

26 Royal Circus Playbill (9 September 1816). 
point of contact with the wider world' that was enhanced by the minor theatres' self-reflexive strategy of specifically locating themselves within the cityscape. ${ }^{27}$

In December 1821 the Coburg would take such autoethnography to its extreme by installing a much-advertised 'looking glass': a 'mirror curtain', consisting of sixtythree glass panels, by which audiences could see their own reflections on stage. ${ }^{28}$ This innovation, although dismissed by some reviewers as nothing more than 'a gewgaw', proved decisive in drawing in the crowds. ${ }^{29}$ In her analysis of the ways in which the minor theatres worked to 'construe a new cultural metropolis', Moody argues that the mirror curtain's resemblance to the plate-glass windows found in contemporary shopping arcades marked 'a significant step in the transformation of the dramatic spectator into the self-conscious purchaser of cultural goods and visual pleasures'. ${ }^{30}$ I would like to underline Moody's stress on 'transformation', not least because the spectacle offered at the Coburg was, in fact, curiously discontinuous.

According to contemporary commentators, not only were the curtain's individual plates quite dull, but 'owing to the numerous divisions in the glass, the whole contour of the scene [was] broken and disjointed'. ${ }^{31}$ In the 1835 series 'London Letters to Country Cousins' (published in The Court Magazine and Belle Assemblée) the curtain thus serves as a metaphor for the creative memory:

[T] he whole formed, not a mirror, but a multiplication table ... putting the head of one person upon the shoulders of another-transferring the plumed bonnet of a third to the bald pate of her next male neighbour-lifting the dirty apprentice out of the back row of the pit into the dress circle - and, in fact, confounding objects, looks, and localities, in a manner amusing enough to the beholder, much more so perhaps, than if it had presented a perfect picture of the scene before it. ${ }^{32}$

In keeping with the letter's light-hearted tone, these incongruous images are initially characterized by nothing more than slapstick comedy; but they soon acquire patently political implications, as highlighted by the imaginative transposal of the 'dirty apprentice' across the socially-tiered auditorium. It is significant that by the time of the letter's publication, the Coburg's mirror curtain had been pulled down (in recognition of the safety issues associated with its sheer weight). The letter's nostalgic tone nevertheless provides a valuable reminder that while the mirror curtain did indeed attract bad press, audiences at large seem to have been much more generous in their responses. As memorialized by the letter's fictive author 'Terence Templeton', the mirror curtain provided an effective act drop precisely because of its

27 Chandler and Gilmartin, 'Introduction', 1.

28 N. M. Bligh, 'Mirror Curtains', Theatre Notebook 15/2 (1960-1): 56. Although Bligh dates the curtain to 1822, it was already on display (albeit not fully complete) by December 1821 . On theatrical autoethnography, see Daniel O'Quinn, Staging Governance: Theatrical Imperialism in London 1770-1800 (Baltimore: Johns Hopkins University Press, 2005), 11 and Entertaining Crisis in the Atlantic Imperium 1770-1790 (Baltimore: Johns Hopkins University Press, 2011).

29 Drama; Or, Theatrical Pocket Magazine 2/3 (1822): 154; and The Times 11439 (27 December 1821): 2 .

30 Moody, Illegitimate Theatre, 148; $154 . \quad 31$ The Times (27 December 1821).

32 'London Letters to Country Cousins. - No. 1', Court Magazine and Belle Assemblée 7 (July 1835): 4 . 
flaws. Failing to deliver 'a perfect picture', the curtain's discordant reflections prompted theatregoers to engage in exercises of self-identification and reinvention that ranged from the playful to the ambitious, and which, by extension, may ultimately have encouraged the Coburg's patrons to recognize and assume their own agency in an ever more aggressive capitalist economy.

\section{POLITICS}

The symbolic advantages of placing the minor theatres at the heart of the metropolitan experience were, therefore, not only aesthetic and commercial, but also pointedly political. As E. P. Thompson notes, radicalism in the capital 'assumed more conscious, organized, and sophisticated forms' after 1815.33 The district of Islington, moreover, was well known for its strong radical sympathies - a fact Charles the Younger had to negotiate with care when devising new entertainments for Sadler's Wells. ${ }^{34}$ In her discussion of Jane Scott's postwar productions at the Sans Pareil, Jacky Bratton concedes that 'there can be, of course, no possibility that the authorities would have overlooked any overtly political play staged in London at this time'; nevertheless, as she concludes, that is not to say that political meanings could not be 'adduced'. 35

The pantomimes for which Sadler's Wells enjoyed such high renown may have offered only passing references to the political issues of the day, but the ever more impressive stage effects that made the city at once familiar and strange encouraged audiences to align their seasonal favourites with the orientalist entertainments that already enjoyed a long association with critiques of governance. By enhancing the harlequinade through visual effects, the artistic team at Sadler's Wells helped realize the potential for what Mayer refers to as the 'retributive comedy' inherent in that part of the pantomime's action. ${ }^{36}$ The harlequinade, which sees the lovers attempt to escape from authority, constitutes the all-important second half of the pantomime. This follows the 'transformation scene', in which a benevolent agent transforms the principal characters of the opening fable into the comic types of Harlequin, Columbine, Pantaloon, and Clown. ${ }^{37}$ The subsequent action is fastpaced and spectacular, Harlequin's magic bat giving him the power to confuse his adversaries by realizing a metamorphosis of the scenes and objects they encounter during their journey. In the pantomime Harlequin's Vision; or, The Feast of the Statue (Drury Lane, 26 December 1817) this included 'the transformation of a chest into a sofa, on which the Clown seats himself, and which is immediately afterwards converted into a kitchen-grate, with a fire briskly burning in it, and

33 E. P. Thompson, The Making of the English Working Class (London: Penguin, 1963; 1970), 662.

34 Ibid., 669.

35 Jacky Bratton, 'Jane Scott the writer-manager', in Tracy C. Davis and Ellen Donkin (eds), Women and Playwriting in Nineteenth-Century Britain (Cambridge: Cambridge University Press, 1999), 77-98, 89.

36 Mayer, Harlequin, 52.

37 For a good description of the basic structure of pantomimes, see ibid., 23-31. 
which gives the Clown an unpleasing hint, a posteriori. ${ }^{38}$ 'Lissom as a cane, and furnishing all that little supply of conscious power which a nervous mind requires, and which is the secret of all button-pulling, switch-carrying, seal-twirling and glove-twirling', Leigh Hunt insisted that Harlequin's magic sword was perfect for the delivery of 'satirical strokes'. 'We always think, when we see it,' he continued, 'what precious thumps we should like to give some persons, - that is to say, provided we could forget our own infirmities for the occasion. ${ }^{39}$ Although Charles the Younger's greatest successes in the years 1800 to 1815 could broadly be described as 'patriotic' entertainments that celebrated the heroism of British soldiers and sailors, Harlequin's silent but energetic stage presence was, by Hunt's colourful description, exceptionally enabling, allowing audiences to imagine 'what supplement they please to the mute caricature before them'. ${ }^{40}$ While I do not want to claim that the pantomimes staged at Sadler's Wells were, in themselves, of an oppositional, much less a 'radical' nature, I do want to suggest that Charles the Younger might, like his father, be best understood as an 'independent loyalist', to borrow the term defined by David Kennerley in Chapter Five of this volume.

The desire at once to mobilize but also to nuance loyalist opinion (as described in more detail below, with reference to Young Arthur) was fraught with challenges. Spikes in unemployment, crime, and vagrancy rates, combined with industrial depression and poor harvests, meant that in the autumn of 1816 conditions in London were ripe for the Spa Field Riots. Although the riots concluded in something of an anticlimax that demonstrated the lack of coherence within the radical movement and ultimately helped middle-class reformers cement a distinction between radical and moderate sympathies, ${ }^{41}$ even this was not enough to forestall a government clampdown. In line with the repressive measures enforced in the 1790s, Habeas Corpus was suspended on 1 July 1817 and the Seditious Meetings Act reinstated. The minor theatres had survived the surveillance culture of the late eighteenth century and would do so again; but managers would need to exercise stringent assessments of the kinds of performance on offer.

During the Napoleonic Wars topicality had been at the top of Charles the Younger's agenda. In 1813, for example, he produced 'two military and musical mélanges' (Memoirs, 107) in celebration of the success enjoyed by British arms in the Iberian Peninsula: Vittoria; or, Wellington's Laurels and The Battle of Salamanca. This preference for military entertainments continued in the postwar years, as exemplified by the already mentioned Russian-themed melodrama Iwanowna and the musical piece Forget-me-not; or, The Flower of Waterloo (1817). Interestingly, although both these entertainments were already relatively dated by the time of their premiere, their very 'belatedness' seems to have carried emotive charge; the 'extremely pleasing' qualities of Forget-me-not, for instance, were explicitly linked to

\footnotetext{
38 Theatrical Inquisitor (January 1818): 51, as quoted in Steven E. Jones, Satire and Romanticism (Basingstoke: Macmillan, 2000), 176.

39 Leigh Hunt, Examiner (26 January 1817). $\quad 40$ Ibid.

41 Thompson, English Working Class, 696.
} 
its 'various popular old airs'. ${ }^{42}$ By 1817 the recourse to familiar tunes was a tried and tested practice for Charles the Younger, who frequently set new songs to existing music or mixed well-known lyrics with his own. As Mark Philp suggests, this could help encourage identification with new causes, framing musical performances as 'multi-layered processes of ideological contestation and confrontation'. ${ }^{43}$ Charles the Younger's decision to extend his wartime repertoire past 1815 may therefore also be indicative of a belief that the war's heroes had yet to be satisfactorily rewarded.

\section{INTERNAL STRIFE}

The start of the 1817-18 season at Sadler's Wells also entailed practical challenges related to theatrical personnel and machinery. Although the British Stage eagerly awaited the theatre's reopening, confident that Sadler's Wells' advantageous vicinity to the New River and Grimaldi's popularity as the 'prince of Clowns' were virtual guarantors of success, 1817 would be remembered as one of the theatre's worst years on record. ${ }^{44}$ Charles the Younger painfully observed that 'we wound up our accounts minus' for the first time since 1800 (Memoirs, 121) - in no small part because this was 'the only Season the Theatre opened without [Grimaldi]' (119). ${ }^{45}$ It took time for Grimaldi's replacement, 'Signor Paulo' (the stage name of Paulo Redigé the Younger), to win over the crowds. ${ }^{46}$ Many of the pantomime songs were suited to Grimaldi alone: Charles the Younger explains that 'when writing them, I had in view much more his peculiarities of what I may call, expression, than any literary fame' (113). As Jim Davis shows in Chapter Ten of this volume, this collaborative method of authorship and dramatic production was an approach also pursued by Charles the Younger's brother, Thomas, and numerous other dramatists in this period. As a result, therefore, of the absence of Grimaldi from the Sadler's Wells company, the pantomimes in which Paulo featured were even more reliant on special effects. Evidence of this takes tangible form in the playbills advertising Sadler's Wells' 1817 pantomime, April Fools! Or, Months and Mummery, which included a scene-by-scene full 'Prospectus of the Pantomime' overleaf.

Yet by 1817 Sadler's Wells' spectacular repertoire was beginning to feel decidedly tired. Even the water tanks had lost their novelty. As Charles the Younger explained:

42 British Stage and Literary Cabinet (August 1817): 183

43 Philp, Reforming Ideas, 256.

44 British Stage and Literary Cabinet (April 1817): 83.

45 In 1815 William Hazlitt responded to false rumours of Grimaldi's death by comparing this possibility to Napoleon's second exile: 'As without the gentleman at St. Helena, there is an end of politics in Europe; so, without the clown at Sadler's Wells, there must be an end of pantomimes in this country!' Examiner (31 December 1815). This was an audacious if humorous claim which, as James Mulvihill underlines, acknowledges 'the extent to which theatre and public life were co-opting each other'. James Mulvihill, 'William Hazlitt on Dramatic Text and Performance', Studies in English Literature, 1500-1900 41/4 (2001: 'The Nineteenth Century'): 695-709, 707.

46 Highfill et al., Biographical Dictionary of Actors, 2:237-9. 
The body of water had become not only familiar, but caviare, from the familiarity; in addition to which, the public had become in a great degree, conversant with the modes and mediums in and through which we effected our aquatic surprises, and hence they excited neither astonishment, nor delight; again, I had exhausted all my inventive fancy, as regarded producing novelties, in the water Scene; and every artist in the Theatre had exhausted his[.] (Memoirs, 120-21)

Not even promises of 'ample remuneration' proved sufficient to excite new ideas for the water tanks' use, while John Astley's investment in a reservoir for his Amphitheatre meant that their very uniqueness was under threat, as Charles the Younger confided in a letter to Lloyd Baker dated 22 December 1817. ${ }^{47}$ Water spectacles would continue to define the theatre's repertoire in the $1820 \mathrm{~s}$, but the final years of Charles the Younger's management were marked, as he notes, by a temporary suspension of their operation as 'a Water Company' (121). By the end of the 1817-18 season, Sadler's Wells must have seemed in desperate need of rebranding.

Grimaldi's reinstatement in 1818 helped relieve some of Charles the Younger's anxieties - but it also produced others. The terms of Grimaldi's return included his purchase of new shares in the theatre, which its manager clearly resented. 'A Theatre', Charles the Younger remarked, 'should be like an absolute Monarchy-as a limited Monarchy it will dwindle-as a Republic (of Proprietors and Committees) the administration will get into confusion, and confusion is the forerunner of defeat' (Memoirs, 122). This distaste for management by committee as opposed to individual direction taps into what David Francis Taylor has identified as 'the constitutive ideological tensions that lie behind the polarized constructions of manager-as-despot and manager-as-trustee'. ${ }^{48}$ Sadler's Wells had been run by a committee since the 1816-17 season, following the deaths of Richard Hughes and William Reeves (in 1815), and Thomas Dibdin's sale of his shares to Hughes's widow. David Arundell observes that during the first committee season profits fell by $\mathfrak{E 5 7 0 . 4 9}$ Internal division among the partners had resulted in a 'complete paralysis' of the Haymarket in $1813 .{ }^{50}$ It is significant, therefore, that Charles the Younger should cite 'a dispute between my Partners and myself' (124) as the main reason for his departure from Sadler's Wells at the end of the 1819-20 season; and, moreover, that he should have stated such open preference for an autocratic model of management, notwithstanding its obviously negative associations (which other managers, as Taylor shows, worked so hard to revise, at least publicly). ${ }^{51}$

\footnotetext{
47 The letter is quoted in David Arundell, The Story of Sadler's Wells 1683-1964 (London: Hamish Hamilton, 1965), 92-3.

48 David Francis Taylor, 'Theatre Managers and the Managing of Theatre History', in Swindells and Taylor, Handbook of the Georgian Theatre, 70-88, 70.

49 Arundell, Sadler's Wells, 91.

50 William Burling, Summer Theatre in London 1661-1820, and the Rise of the Haymarket Theatre (London: Associated University Presses, 2000), 195.

51 Taylor, 'Theatre Managers', 86-8.
} 
Charles the Younger began writing Young Arthur in the winter of 1818, putatively to 'divert [his] mind' from the theatre's troubles and 'for the purpose of combatting some greatly prevailing polemical and political opinions' (Memoirs, 124). His turn to romance is a suggestive one. The genre was in fashion in the 1810s: Byron had used the label 'romaunt' for Childe Harold's Pilgrimage, while Thomas Moore's 'Oriental Romance' of Lallah Rookh, as already mentioned, had been adapted by Charles the Younger for the stage in 1817 . The success enjoyed by these poems further suggests that commercial considerations were likely to have been just as prevalent in Charles the Younger's decision to describe Young Arthur as 'a metrical romance'. Young Arthur was published by the Longman, Hurst, and Rees consortium of booksellers and was relatively expensive at $14 \mathrm{~s}$. for an octavo of 322 pages. It promised income that its author desperately needed by 1819 (then in debtor's jail, pleading 'a wee bit bread', as his verse dramatically explains). ${ }^{52}$ But in much the same way that Byron's Childe Harold's Pilgrimage exceeds its designation as a 'romaunt', so too does Young Arthur's generic classification prove something of a misnomer.

Charles the Younger's long poem is divided into eleven 'Subjects' (rather than books), each featuring a 'Variation' in the manner of Henry Fielding's prefatory chapters to The History of Tom Jones, A Foundling (1749). The third Variation, for example, is entitled 'A Short Stop for breathing, with Hints in Hudibrastic'. There are also several shorter inset poems, ballads, songs, and footnotes throughout. This diversity garnered mixed criticism. The Literary Gazette suggested that 'Songs, laments, episodes, ballads, hymns \&c are introduced so abundantly, as to give the whole the air of a medley, rather than a uniform composition', while the Literary Chronicle suggested that such variety was bound to suit 'all palates'. ${ }^{53}$ 'Medley' is the keyword here. As David Duff explains, British Romantic texts tend to fall into one of two camps: 'Typically, they overstate, overperform, or protest too much about their generic affiliations, often by fusing genres and multiplying their generic identity... Or, alternatively, they subvert, ironize, or conceal their generic provenance, aspiring to transcend their chosen genre or delivering only a partial or marginal performance of it.' 54 'In theory as well as in critical practice', Robyn Warhol-Down argues, 'genre is not a neat classification system for settling questions about what texts mean or how they work. Instead, the concept of genre opens up vistas on the ways a text can function in literary history, in a reader's hands and mind, or in material developments within the extratextual world. ${ }^{55}$ In Young Arthur Charles the Younger takes clear satisfaction in pushing at the limits of his readers' expectations.

\footnotetext{
52 Charles Isaac Mungo Dibdin, Young Arthur; or, The Child of Mystery: A Metrical Romance (London, 1819), 95. Further references are given after quotations in the text.

53 Literary Gazette (July 1819): 484; Literary Chronicle and Weekly Review (August 1819): 212.

54 David Duff, Romanticism and the Uses of Genre (Oxford: Oxford University Press, 2009), 19.

55 Robyn Warhol-Down, 'Introduction: Genre Regenerated', in Robyn Warhol-Down (ed.), The Work of Genre: Selected Essays from the English Institute (Cambridge, MA: English Institute in collaboration with the American Council of Learned Societies, 2011), unpaginated (20).
} 
The poem represents an ambitious performance in terms of its geographic as much as its generic span. Between them, the poem's male protagonists, Ernest (the eponymous 'Young Arthur') and Allan experience adventures in Peru, Tunis, and the Arabian deserts. But England, significantly, provides the point of return for all of the poem's characters. Frequently apostrophized as a land of liberty and beneficence, the poem repeatedly invites its readers to make parallels between England in the sixteenth and early nineteenth centuries. To this end, the Variations are recognizably modern, often addressing the reader directly and making several references to contemporary culture. Their relation to the main narrative is sometimes rendered explicit, as in Subject VII, wherein Allan's description of 'the sultry Simoom's poisonous gale' is glossed by a footnote defining the Simoom as 'a baleful wind that blows perpetually over the desarts [sic] of Arabia; to which Europeans generally fall a sacrifice' (Young Arthur, 188). This image is then reused in the accompanying Variation ('The Groans of Britain, and a Legend ad libitum'), where the narrator offers a penetrative diagnosis of the moral state of the nation:

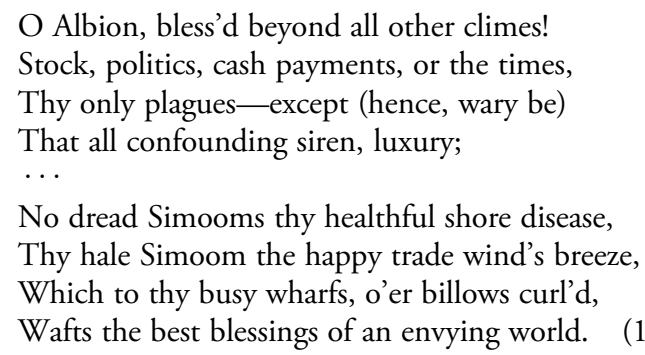

The passage testifies to the acute concern over moral values that characterized the postwar years. 'There is scarcely a page in which some moral truth is not expressed, or some vice held up to detestation, or some folly satirized,' affirmed the Literary Chronicle. ${ }^{56}$ The warning against luxury, for instance, is inflected, not only by the main narrative's description of the Spanish conquest of Peru ('The Stranger's Tale', Subject III) but by repeated attacks on the dandy as 'a new insect of the 19 th century ... a non-descript' (231).

Charles the Younger's other chief satirical target in the poem is religious fanaticism, justifying a curious reference to 'the imposter' Joanna Southcott (Young Arthur, 127), and two extended passages on differences between religious creeds that define Variation V and Subject VII. In each instance, the author adds a footnote in which he insists that his attack is not directed at religious sects but 'the "troublers of religion"' (126) or 'the sanctimonious' (169), as he later calls them. Charles the Younger here conforms to what Eric Hobsbawm has illuminatingly described as a 'marked parallelism between the movements of religious, social and political consciousness'. 57

\footnotetext{
56 Literary Chronicle and Weekly Review (August 1819): 212.

57 As quoted in Thompson, English Working Class, 427.
} 
At this point it is worth noting that the proprietors of Sadler's Wells took deliberate care to remove prostitutes from the theatre and to promote middleclass moral values. Islington became 'an area noted for its evangelical churches, schools, hospitals and reformatories', its urbanization taking off between 1800 and 1821 when new streets such as Exmouth Street, Myddleton Street, Spencer Street, and Ashby Street were built to accommodate the middle classes. ${ }^{58}$ This middleclass reformation of Islington was as much behind Charles the Younger's attempts to reinvent Sadler's Wells' postwar repertoire as it was influential to the shaping of Young Arthur's moralistic vein.

The points of contact between Charles the Younger's poetic and theatrical enterprises can be seen in the various performance-related allusions that recur throughout Young Arthur. These take a range of forms, from the song 'Fancy dipp'd her pen in dew', used as the opening for Subject VII and glossed in a footnote as having been 'sung by Miss Stephens, composed by Mr Whitaker' (Young Arthur, 164), to 'Sir Brandon's History' (Subject IX), which is prefaced by a curious roll-call of the contemporary actors who most distinguished themselves in the role of Richard III (Garrick, Kemble, Cooke, Young, and Kean). Such observations obviously detract from the romance narrative, but rarely without purpose. (The latter, in particular, is likely to have been intended as a sly dig at Astley's Amphitheatre, where an equestrian version of Richard III had recently been performed.) ${ }^{59}$

It is not entirely surprising, then, that notwithstanding its label as a 'metrical romance', several magazines and journals catalogued Young Arthur as a 'drama'. ${ }^{60}$ This generic confusion can be regarded as a fruitful extension of the 'medley-like' qualities attributed to Young Arthur specifically, and which, in light of Duff's argument, we can also see as representative of Romantic literature more generally. Although his earliest publication had been a volume of poems called Poetical Attempts: by a Young Man (1792), Charles the Younger was clearly anxious about the state of modern poetry and the likely reception that would be accorded to Young Arthur. In the poem's preface he takes care to define himself against the greater celebrity of both his father and brother Thomas ('author of several Dramas, and a Metrical History of England' (Young Arthur, vi)), while his introduction satirizes modern poetry as a degenerate form. The 'monitory' function that Gérard Genette associates with the preface is certainly active here, as Charles the Younger advises readers both 'why' and 'how' his romance should be read. ${ }^{61}$ What he fails to explain, of course, is that Young Arthur is not, as argued above, much of a romance at all. Consequently, as the poem develops,

\footnotetext{
58 Jim Davis and Victor Emeljanow, Reflecting the Audience: London Theatregoing, 1840-1880 (Iowa City: University of Iowa Press, 2001), 109.

59 Unmarked clipping, Victoria and Albert Museum Theatre Collection, 'Astley's Amphitheatre' box.

60 The 'New Publications' issued by the Quarterly Review (April 1819: 559) thus labelled the poem a 'drama'. The Edinburgh Annual Register, on the other hand, listed Young Arthur under 'Novels, Tales and Romances' (January 1819: 510).

${ }^{61}$ Gérard Genette, Paratexts, trans. Jane E. Lewin (Cambridge: Cambridge University Press, 1997), 197.
} 
what passes as the preface's customary modesty topos becomes an invitation for criticism, rather than a forestalling of it: 'Sir, I hope you're a much better Christian than poet,' the narrator later states (299).

The Literary Chronicle, which published the most enthusiastic of Young Arthur's reviews, insisted that authorial apologies were unnecessary. The reviewer not only affirms that Charles the Younger already enjoyed 'a pretty firm hold of the public', but goes so far as to suggest that the short Hymn in Subject III ('There is an eye that all surveys') is a composition worthy of Isaac Watts and Joseph Addison. ${ }^{62}$ The Literary Gazette concurred-to an extent. Charles the Younger's reputation, its reviewer explained, was as 'a writer generally engaged in less laboured compositions; and accustomed to snatch a temporary achievement of the day, rather than to address himself to more grave and elevated efforts'. But 'the practice of writing for a minor theatre is most likely to improve, than deteriorate literary talent', the reviewer added, reminding readers of the Dibdin family's celebrity. ${ }^{63}$ On this point the Monthly Review; or, Literary Journal disagreed entirely, however. Charles the Younger was but a pale imitation of his father: 'Where is the vigour,- -where is the neatness,-where is the good-humoured flow of soul of that lamented parent?' ${ }^{64}$ Although the review concludes by asserting that a 'frivolous, vain, and vapid race of modern poets' meant that poetry itself was in a bad state, the Monthly Review had little time to spare for Charles the Younger's attempts to show off his talents for different rhyme schemes and forms.

Young Arthur was simply not enough of 'a romance' and too much of a mixed performance. Refusing fully to honour his promise of 'a metrical romance', Charles the Younger produced, instead, a 'medley', characterized by similar strategies to those he pursued as an arranger of pantomimes. The pantomime was a form that always aimed at more than one subject: as Mayer explains, 'Its structure enabled fleeting comedy or satire to be directed at many topics without requiring that they be shown in a logical or plausible sequence.' 65 Young Arthur's generic indeterminacy thus gained considerably greater purchase from Charles the Younger's understanding that with pantomimes, especially, it was often preferable to be 'random' rather than 'precise'. ${ }^{66}$ This theatrical context permits Young Arthur to be read productively as a poetic translation of the 'whole programme' offered by a minor theatre such as Sadler's Wells, where the nightly entertainments ranged from pantomimes to melodramas, with dancing, singing, and gymnastic feats in between.

\section{THE 'MEDLEY’ AS METAPHOR}

Shortly after completing Young Arthur, Charles the Younger opened his final season at Sadler's Wells. The year 1819 would prove a difficult one for most of London's

\footnotetext{
62 Literary Chronicle and Weekly Review (August 1819): 211.

63 Literary Gazette (July 1819): 484.

64 Monthly Review; or, Literary Journal (February 1820): 211.

65 Mayer, Harlequin, $6 . \quad 66$ Ibid.
} 
minor theatres, including the Sans Pareil, Olympic, and indeed even the Haymarket, London's summer patent theatre. The study of Sadler's Wells' history between 1814 and 1819 allows us to make various inferences as to the reasons for Charles the Younger's unexpected departure, and to put pressure on the too tidy narrative that he provides in his Memoirs. Generalized postwar depression and discontent certainly impinged upon the manager's success, but other, more immediately practical considerations were also at stake, as this chapter has outlined. By the late 1810s, Sadler's Wells faced increased competition in the form of rival spectacular entertainments, the difficulties of operating in a period of acute political unrest, and localized friction within its own managerial committee.

Charles the Younger was not, finally, able to weather the storm and, in his own words, found himself 'a Captain out of Commission' (Memoirs, 126). Whereas Jane Scott at the Sans Pareil was able to keep her theatre successful by engaging in a 'daily weaving of variations upon successful patterns', ${ }^{67}$ after 1817 this was less of an option for Charles the Younger, whose audiences had tired of the 'novelty' of aquatic exhibitions after more than a decade of such entertainments. But the extended staging of a wartime repertoire at Sadler's Wells, for example, points not only to Charles the Younger's attempts to deliver continuity, but to take advantage of his reputation in order to engage with postwar politics at a time of significant repression.

Although the government's clampdown on radical opinion makes it difficult to recover Charles the Younger's political allegiances with any confidence, the entertainments at Sadler's Wells and Young Arthur mutually suggest that he was committed to advancing limited reform. Acutely aware of his own and his audiences' social standing, Charles the Younger responded to and actively encouraged the development of Islington's middle-class communities by investing ever more heavily in a moralistic repertoire, both on stage and off, as exemplified by Young Arthur. The metaphor of the 'medley' offers a neat embodiment of this, not least because during the course of the nineteenth century the musical medley would become increasingly associated with a popular audience, while music for the elite concentrated more exclusively on one genre or perspective. Literary, musical, and dramatic medleys were not, of course, one and the same: but the notion of a blending together that allows for influences to remain distinct provides, perhaps, the most useful model by which to examine the imbrication of theatrical and political economies that characterized Charles the Younger's final years at Sadler's Wells. 


\title{
10 \\ Writing for Actors \\ The Dramas of Thomas Dibdin
}

\author{
Jim Davis
}

Thomas Dibdin was 'a prolific dramatist and an incredibly hard-working theatrical jack-of-all-trades: songwriter, scene-painter, actor, prompter, stage manager, theatre manager, and author of some 250 plays'. ${ }^{1}$ As well as early employment in the provinces he worked at various times at Sadler's Wells, Covent Garden, Drury Lane, the Surrey, and the Haymarket theatres. His Reminiscences attest to the collaborative nature of his engagement in contemporary theatre-making and to the fact that individual agency was often subsumed by the collective needs of theatres and their companies. As such he was very much part of a series of theatrical networks that, as discussed elsewhere in this volume, his own father, among others, had helped to foster. In this chapter I want to look specifically at Thomas Dibdin the dramatist and collaborator, both in terms of Leigh Hunt's hostile critical reaction to his work and in terms of Thomas Dibdin's creation of roles for actors.

Hunt opens his Critical Essays on the Performers of the London Theatres by remarking, "The first time I ever saw a play was in March 1800 ... After that I was present at the comedies of Mr Reynolds and of Mr Dibdin, and I laughed very heartily at the grimaces of the actors; but somehow or another I never recollected a word of the dialogue. [To] any schoolboy, who had been accustomed to nothing but natural objects, all the Irishmen, and all the gabbling humourists are alike, the author becomes a mere dependent on the player.'2 Hunt considered that comedy on the printed page was rendered unreadable, since the contemporary dramatist's principal design in forming a character was to 'adapt it to that peculiar style of the actor, which the huge farces have rendered necessary to their existence'. ${ }^{3}$ Thus rustic characters were always adapted to John Emery, while 'the loss of Munden who gives [Modern Comedy] such a variety of grin would affect [the author] little less than a lock-jaw'. ${ }^{4}$ Criticizing, in particular, the comedies of Frederick Reynolds and Thomas Dibdin, Hunt complains that both dramatists created unnatural

1 Michael R. Booth (ed.), English Plays of the Nineteenth Century V. Pantomimes, Extravaganzas and Burlesques (Oxford: Oxford University Press, 1976), 69.

2 Leigh Hunt, Critical Essays on the Performers of the London Theatres including General Observations on the practise and genius of the stage (London, 1807), vii-viii.

3 Ibid., viii. ${ }^{4}$ Ibid., vii. 
characters that the comic actors were forced 'to grimace and grin ... into applause', creating bad habits from which they were unable thereafter to wean themselves: 'The extravagance therefore of look and gesture, so necessary to the caricatures of our farci-comic writers, they cannot help carrying into the characters of our best dramatists, to which it is every way injurious. ${ }^{5}$ Although Hunt later backtracked to some degree in his criticism of both dramatists and actors, he inadvertently draws attention to just how dependent dramatists were on the creative skills of the comic actors for whom they wrote. Yet he regularly attacks Thomas Dibdin, as in his scathing review of Bonifacio and Bridgetina, or in his passing comments on Dibdin and other dramatists as 'a standing jest'' in a review of The Conscious Lovers.

Bonifacio and Bridgetina; or the Knight of the Hermitage; or the Windmill Turrett; or the Spectre of the North-East Gallery (Covent Garden, 1808) was, for Hunt, 'the most stupid piece of impertinence that has disgraced the English stage for some years past'. Indeed, he continues, 'when such a writer as $\mathrm{Mr} \mathrm{T}$. Dibdin commences dramatic satirist, the critics must naturally be surprised enough to enquire into his pretensions to so unexpected an office'. 7 In Hunt's view Thomas Dibdin's incapacity to write effective melodramas rendered him equally incapable of burlesquing the form: 'Mr Dibdin, who has no sort of taste for real heroic, has of course been totally ignorant how to ridicule the violation of it in others. '8 For Hunt, Dibdin's failure was an inability to understand burlesque and the mock heroic and how to use them effectively. Whatever the shortcomings of Dibdin's burlesque, the play itself certainly belies Hunt's dismissive rejection, for it provides an effective and early example of theatrical satire on melodramatic excess, which both critiques and shows affection for the form. The prelude to the play is set in a corridor behind the boxes just before the play begins. The author lists the many melodramatic features included in his play, to which another character, Medley, responds:

MEDLEY: Then, what else can be wanting?

AUTHOR: Nothing but a conflagration in the last scene; the combustibles for which are in preparation at this very moment.

MEDLEY: Such things should finish with a conflagration; but how d'ye put it out?

AUTHOR: Can't you guess?

MEDLEY: No.

AUTHOR: No! then you shall own this to be the most surprising thing of all, and only reserved for this age to accomplish. We absolutely mean to extinguish it with real water

MEDLEY: Extinguish fire with real water! My dear boy, let me embrace you!?

Later in the actual play, after being confined to a haunted windmill tower, the heroine declares, 'Upon my honour, if the balcony was a little lower, I'd throw myself down, and be dashed to pieces, before I'd put up with this usage.' ${ }^{10}$ These

5 Ibid., 81.

6 Examiner (21 January 1810), cited in L. H. and C. W. Houtchens (eds), Leigh Hunt's Dramatic Criticism 1808-1831 (London: Geoffrey Cumberlege, 1950), 35.

7 Ibid., 10 (Examiner, 10 April 1808). $\quad 8$ Ibid., 11 (Examiner, 10 April 1808).

9 Thomas Dibdin, Bonifacio and Bridgetina; or, The Knight of the Hermitage; or, The Windmill Turrett; or, The Spectre of the North-East Gallery (London, 1808), 11-12.

10 Ibid., 43. 
examples seem no better or worse than other examples of melodrama burlesques; indeed, subsequent commentators have been to Thomas Dibdin than Hunt when discussing Bonifacio and Bridgetina. ${ }^{11}$

In his Autobiography Hunt indicates that his chastisement of contemporary dramatists was not altogether fair: 'I forgot that it was I who was the mere boy, and that they knew twenty times more of the world than I did.' 12 However, he seems less than contrite about his treatment of Thomas Dibdin, who had dared to write a letter (which Hunt published) complaining of a review Hunt had written. On 10 April 1807 Hunt published a review of the pantomime Ogre and Little Thumb, lambasting the author, whom he assumed must be Thomas Dibdin on account of the 'very bad' English introduced into the 'very short' songs written for the piece. He continued:

It requires some degree of condescension in a critic to enter into a disquisition on the comedies of Mr. Dibdin, but to notice his pantomimes would have been an intolerable task, had we not thought it necessary to caution parents how they introduce their children to spectacles in which both the human mind and the human body are rendered disgustingly monstrous, and which may excite a prematurity of imagination without exalting, refining, or moralising it. ${ }^{13}$

Dibdin's restrained response remonstrated with Hunt for what he felt was his "unfair critical hostility' ${ }^{14}$ towards him, while also pointing out he was not the author of the pantomime in question. Hunt, however, returned to the attack, claiming that Dibdin 'with the usual importance of endured scribblers, talks of the frequent indulgence shown him by the public; that is, he has assisted to deprave the taste of the town and then he is tolerated by it... After all, where is this fancied indulgence shown to Mr. Dibdin, or Mr. Reynolds, or Mr. Cherry, or Mr. Cobb, or to any other disgrace of the stage?'15

Hunt had continually excoriated contemporary dramatists for their low standards. In 1807 he attacked the Haymarket Theatre, which provided Londoners with a diet of comedy and farce during the summer season, in a polemical piece written for the News. He complained that its endless revival of old 'hits', such as The Heir at Law, Catch Him Who Can, and Five Miles Off, 'may be compared to that merry machine in a fair, the round-about. It appears, season after season, of the same ancient wooden composition, a little newly painted, with the same unchangeable powers of attraction, and the same monotony of entertainment.' ${ }^{16}$ Hunt regretted that the manager, George Colman the Younger, was providing the theatre with plays by 'those miserable writers he now endures' instead of his own dramas. Yet Hunt's mistake was to apply his literary notions of what the Drama should be, without taking into account the commercial considerations of running a theatre,

\footnotetext{
11 See V. C. Clinton-Baddeley, The Burlesque Tradition in the English Theatre after 1660 (London: Methuen \& Co., 1952, repr. 1973), 88-90; Booth, English Plays, 30-1.

12 J. E. Morpurgo (ed.), The Autobiography of Leigh Hunt (London: The Cresset Press, 1959), 15.

13 William Archer and Robert W. Lowe (eds), Dramatic Essays by Leigh Hunt (London, 1894), xxviii.

${ }^{14}$ Ibid., xxviii. $\quad 15$ Ibid., xxix. $\quad 16$ News (21 June 1807).
} 
the demands of the audience, and the requirements of the actors. Comic actors such as John Liston, Joseph Munden, and John Fawcett relied heavily on technique and established comic personas; the literary quality of their material was largely irrelevant. Nevertheless, Hunt wrote a series of articles devoted to an analysis of the decline in comic drama, which were printed in the News during the summer of 1807 .

Hunt felt that the bad side of early-nineteenth-century comedy was epitomized in the writings of Theodore Hook, Reynolds, and Thomas Dibdin. He accused them of using too many puns and of deforming (or exaggerating) comic characters in order to obtain easy laughs. He found their language either too flowery or too familiar and disapproved of their frequent attempts to win the audience's sympathy through an affectation of loyalty or through obsequious prologues and epilogues. Consequently, the qualities of the best eighteenth-century comedies had now degenerated into 'mere noise and grimace'. ${ }^{17}$ Lack of critical opinion was to blame for this, due to the political involvement and/or partisanship of newspaper editors. Deprived of these external constraints, comedy had sloughed off its moral responsibilities, representing characters who were often too far-fetched to offer any resemblance to the criticism of real life.

Simultaneously, many authors acknowledged that the plays and roles they created for actors were mere sketches that the actors then filled out. This was certainly the case with Charles Mathews the Elder, whose adeptness at filling out the parts which others wrote for him as mere sketches implies a mixture of observation and imagination that enabled him to achieve a range of original creations. The part of Dick Cypher in Hit or Miss (1810), for example, was written for Mathews by Isaac Pocock 'with a mere outline (as it often happened) for Mr. Mathews to fill up'. ${ }^{18}$ Flexible, in James Kenney's Love, Law and Physic (1812), was initially a part that dissatisfied Mathews, as it was 'one of those productions which [he] so frequently had presented to him "to fill up for himself"'. ${ }^{19}$ Indeed Hook pays tribute, in his prefaces to Music Mad (1807) and Killing No Murder (1809), to Mathews' ability to bring to life and fill out the mere sketches that Hook had written. ${ }^{20}$ Hook, whom Hunt considered 'would not do better if he were to write badly on purpose', ${ }^{21}$ conceded that he was providing 'sketches' or 'outlines', although his novel Gilbert Gurney reveals just how chastening it was for the dramatist to be present at the first reading of their play in the green room. Gurney, like Hook, is a young playwright, lucky enough to have a play accepted by the Haymarket management. He soon learns that professional jealousies have to be assuaged-'If Mr Mathews had a song, Mr Liston would expect to have one also'and is chastened by the actors' lack of enthusiasm on the first reading of the play.

\footnotetext{
17 News (30 August 1807).

18 Isaac Pocock, Hit or Miss! A Musical Farce in Two Acts (London, 1811), 3, and Ann Mathews, Memoirs of Charles Mathews, Comedian 4 vols (London, 1839), 1:421.

19 Mathews, Memoirs, 2:223.

20 Theodore Hook, Music Mad. A Dramatic Sketch (London, 1808), iii-iv.

21 News (20 September 1807).
} 
He makes it clear that the power lies with the actors rather than with the authors in determining what will be performed, particularly regarding the question of whether the actors will be willing to undertake the roles assigned them. ${ }^{22}$

If we were to analyse Thomas Dibdin's career as a dramatist on the basis of Hunt's strictures, we might well find him wanting. However, if we consider how Dibdin enables the creativity of actors and engages with the requirements of theatres and managements, we may arrive at different conclusions. In his preface to Thomas Dibdin's The Cabinet George Daniel draws attention to the dramatist's assumed role in casting the opera, first performed at Covent Garden in 1802: '[T] he author appears to have had his own way in choosing his performers; hence, there have been few pieces better acted, or more favourably received.' 23 The opera, says Daniel, was composed for the 'exclusive display' of the popular singer, John Braham: 'There is no character with which Braham is so completely identified as Prince Orlando. The songs are his individual and exclusive property; and anyone attempting to sing them is like an invasion of his right. Among the most favourite are-My Beautiful Maid, Fair Ellen, and the celebrated Palocca. ${ }^{24}$ Although Dibdin wrote many songs, not many were as successful as some of those he wrote for The Cabinet. Yet even the process of providing songs for this and other dramas was a complicated process:

In the course of rehearsing 'The Cabinet,' I met with innumerable difficulties respecting the songs, \&c. Incledon and Braham were to be kept equally in the foreground: if one had a ballad, the other was also to have one; each a martial or hunting-song; each a bravura; and they were to have a duett, in which each was to lead alternately. I, however, managed so as not to affect the general construction of the opera, although I wrote nearly twenty different subjects for music before I satisfied every one: several of these were to suit the difficult taste of Madame Storace... Yet 'The Cabinet' gave me infinitely less trouble than any opera I subsequently produced. 'Zuma,' in particular, had so many additional and unnecessary scenes written for the introduction of bravuras, concerted pieces, \&c. and became so altered in the essential parts of its story, ... that, when produced, it no more resembled its former self, than 'She Stoops to Conquer' would be like the 'Battle of Hexham'. 25

Dibdin acknowledges that, as an author, he is required to meet the demands of actors and managers, sometimes with dire consequences to the cohesion of the drama as originally written. Yet he is also generous towards actors, many of whom materially contributed to the success of his plays. Dibdin certainly recognized his indebtedness to actors for bringing his plays to life. Not only did he dedicate his two-act farce What Next? to the comic actor William Dowton, whose contribution to the success of one of his earliest plays The Jew and the Doctor he acknowledges in his Reminiscences, but he wrote in his preface that, while Shakespeare and Terence

22 Theodore Hook, Gilbert Gurney, 3 vols (London, 1836), 1:80-1.

23 George Daniel, 'Remarks', in Thomas Dibdin, The Cabinet (New edn, London, 1829), 4.

24 Ibid., 4.

25 Thomas Dibdin, Reminiscences, 1:323-4. Zuma was first performed at Covent Garden in 1818. Harris was the manager of Covent Garden. 
had also availed themselves of the Plautine origins of the piece, he doubted whether 'either of those great authors were ever seconded by such actors as those who have supported this farce. Mr. Dowton and Mr. Knight must be seen, to estimate the author's obligations to them; Mr. Oxberry has made much out of nothing. ${ }^{26}$

The importance of collaboration is certainly true of Thomas Dibdin's relationship with Joseph Grimaldi, whom he knew through his association with Sadler's Wells Theatre. He claims that he advised Harris, the Covent Garden manager, to engage Grimaldi, which he did in 1806, and that he persuaded Grimaldi to ask Harris for a higher salary than he had originally intended. ${ }^{27}$ During Grimaldi's first season Thomas Dibdin revived a pantomime that had been rejected by the management five years earlier, Harlequin and Mother Goose, or The Golden Egg, the unexpected success of which consolidated Grimaldi's reputation as the outstanding Clown of Regency pantomime and accentuated the process of placing the Clown as the central character in the genre. Dibdin's Harlequin in his Element; or Fire, Water, Air and Earth (1807) was performed the following year; Grimaldi subsequently looked back on this pantomime as one of his favourites. ${ }^{28}$ Without the combination of Grimaldi's talent as a performer, Dibdin's facility at creating pantomimes, and Charles Farley's skill at staging them, the history of English pantomime might have turned out very differently.

\section{MUNDEN AND DIBDIN}

In order to argue further for Thomas Dibdin's value as a dramatist to actors, I want to consider roles that he wrote specifically for two comic actors, Joseph Munden (1758-1832) and John Liston (1776-1846). Thomas Dibdin wrote several parts for Munden, who specialized in low comedy roles. In 1790 Munden joined the Covent Garden company in London, scoring a particular success in 1792 as Old Dornton in Thomas Holcroft's The Road to Ruin, one of many old gentlemen roles in which he came to specialize. In 1811 he moved to Drury Lane, where he created few new roles, retiring in May 1824. Charles Lamb considered him the outstanding low comedian of his generation: 'There is one face of Farley, one of Knight, one (but what a one it is!) of Liston; but Munden has none that you can properly pin down and call his. When you think he has exhausted his battery of looks, in unaccountable warfare with your gravity, suddenly he sprouts out an entirely new set of features, like Hydra. He is not one, but legion. Not so much a comedian as a company ... He, and he alone, literally makes faces. ${ }^{29}$ For Lamb, Munden was no mere caricaturist, but a comic actor capable of deep and subtle characterization.

26 Thomas Dibdin, What Next?, in Thomas Dibdin (ed.), The London Theatre, 6 vols (London, 1815), 2:3. Oxberry and Knight were also popular comic actors.

27 Dibdin, Reminiscences, 1:399-400.

28 Richard Findlater, Joe Grimaldi, His Life and Theatre (Cambridge: Cambridge University Press, 1978), 125.

29 Charles Lamb, 'On the Acting of Munden', in R. H. Shepherd (ed.), The Complete Works in Prose and Verse of Charles Lamb (London, 1878), 375. 
In 1799 Covent Garden produced, says Thomas Dibdin, 'a musical piece in commemoration of our numerous naval triumphs ... the principal character in it was a Quaker, which was inimitably well acted by Mr Munden'. ${ }^{30}$ This was The Naval Pillar, and it led to pressure on Dibdin to drop the Quaker character by Elizabeth Inchbald, who was shortly to bring out a comedy containing a full family of Quakers. Dibdin refused and was supported by the Covent Garden management in so doing. In the same year he was responsible for The Birthday, adapted from Kotzebue's Die Versöhnung, in which two feuding brothers are reconciled. One of the brothers, Captain Bertram, was played by Munden. According to Munden's son, his father 'always considered that Captain Bertram was his chef d'oeuvre in sentimental comedy; so unique was his performance, that few have attempted the part since'. ${ }^{31}$

Although some coolness subsequently arose between Munden and Thomas Dibdin after the former withdrew from one of Dibdin's plays he had been rehearsing, ${ }^{32}$ they were soon reconciled. In 1815, by which time Munden had moved to Drury Lane, Dibdin was to provide the actor with his last original part, that of Dozey in Past Ten O'Clock and a Rainy Night. This, says Dibdin, 'was given with the same excellence which characterised his Captain Bertram, Mainmast, and several other parts I had the good fortune to write for him'. ${ }^{33}$ Munden played a Greenwich pensioner, in the service of a master called Old Snaps. The play was simple and Munden's son implies that 'there was little in the part itself, which, in the hands of an ordinary actor, would have been insignificant' and that his father had 'slender materials to work upon'. ${ }^{34}$ However he 'took as much pains with his part, as if he were a young actor struggling for fame. He dressed and painted the old Greenwich pensioner to the life (he painted his neck which was bare) and laboured to produce a perfect personification. His chief point in the dialogue was the description of a naval engagement, in which he was wonderfully energetic, and was cheered by loud bursts of applause from the audience. ${ }^{35}$ The role was selected by Munden for his farewell performance at Drury Lane on 31 May 1824, and it is thanks to this occasion that we possess several accounts of his performance as Dozey. Particularly valuable are those by T. N. Talfourd and by Lamb. Talfourd refers to the 'sublime stupidity' of drunken Dozey and considers it the most extraordinary of all Munden's personifications, for ' $[t]$ his old tar-stupefied with age and grog-seemed absolutely grand in the robustness of his frame and the rolling self-satisfaction of his gait, as one who had out-braved 'a thousand storms, a thousand thunders'. For Talfourd 'it was indeed a triumph of art... a more characteristic picture was never exhibited in the drollest farce; nor was ever a truer or nobler burst of feeling called forth in the stateliest tragedy. ${ }^{36}$

30 Dibdin, Reminiscences, 1:261.

31 T. S. Munden, Memoir of Joseph Shepherd Munden, Comedian (London, 1846), 80.

32 Dibdin, Reminiscences, 1:290. 33 Ibid., 2:44.

34 Munden, Memoir, $242 . \quad 35$ Ibid., 243.

36 New Monthly Magazine (May, 1824), quoted in Munden, Memoir, 299. 
Lamb's comments are equally eulogistic. He refers to the audience's familiarity with 'old tobacco-complexioned Dozey', for they had all previously seen 'the weather-beaten old pensioner, dear old Dozey, tacking about the stage in that intense blue sea-livery_-drunk as heart could wish, and right valorous in memory'. ${ }^{37}$ After seeing Munden play the other role selected for his farewell benefit, Sir Robert Bramble in Colman's The Poor Gentleman, Lamb reports:

[I]n the farce he became richer and richer. Old Dozey is a plant from Greenwich. The bronzed face — and neck to match - the long curtain of a coat - the straggling white hair,- - the propensity, the determined attachment to grog-are all from Greenwich. Munden, as Dozey, seems never to have been out of action, sun, and drink ... His face and throat were dried like a raisin — and his legs walked under the rum-and-water with all the indecision which that inestimable beverage usually inspires. It is truly tacking, not walking. He steers at a table, and the tide of grog now and then bears him off the point... In the scene where Dozey describes a sea fight, the actor was never greater, and he seemed the personification of an old seventy-four! ${ }^{38}$

Even if, as Munden's son suggests, the role might not have fared so well in the hands of an ordinary actor, Thomas Dibdin clearly provided Munden with the freedom and scope to create one of his most memorable and successful roles.

\section{LISTON AND DIBDIN}

John Liston made his first London appearance as a comic actor at the Haymarket summer season of 1805 , subsequently joining the Covent Garden company that autumn. He made little impact initially, but his pairing with Charles Mathews at the Haymarket for a consecutive series of summer seasons helped to establish his reputation. He excelled in a line of arrogant, conceited, cowardly, and parochial provincial and cockney characters, often written especially for him, but also played comic roles in melodrama, Shakespeare, and Scott adaptations. In 1823 he joined the Drury Lane company, but created the outstanding success of his career, the title role in Paul Pry, at the Haymarket in 1825. From 1831 until his retirement in 1837, he played comic roles at the Olympic Theatre under the management of Eliza Vestris. Liston's celebrity as a low comedian was to some extent involuntary. His face and body were grotesque and ludicrous — one reason why his likeness was so often depicted by contemporary caricaturists - and his mere presence on stage was sometimes sufficient cause for laughter. He also excelled at suggesting vacuity: 'In his portraits of some of the heroes of cockney-land, he manages to exclude the slightest glimmering of intelligence from his countenance, and at the same time contrives to throw into it an air of conceit and self-satisfaction, which conveys to you he is not only without an idea, but that any attempt to innoculate [sic]

37 London Magazine (May, 1824), quoted in Munden, Memoir, 300.

38 Ibid., 301-2. 
him with one would be altogether hopeless. ${ }^{39}$ Despite the seeming effortlessness of his performances, many critics attested to his technical skill and careful study as an actor.

This popular comic actor played in several pieces by Thomas Dibdin, including Five Miles Off or, The Finger Post (1806), Harlequin Hoax (1814), and Morning, Noon and Night (1822). Colman the Younger, then manager of the Haymarket, had commissioned Five Miles Off from Dibdin for the sum of $£ 200 .{ }^{40}$ The plot hinged upon the confusion caused by a finger (sign) post pointing in the wrong direction. Liston played Flourish, a painter and Quaker, whose job was to put the signpost to rights. He informed the audience of this in the Quaker vernacular, 'It appertaineth not unto my business to set it right; he hath left it pointing to the paths of error; - and I will bear witness against him, when the travellers he may lead astray shall seek redress from the men of wigs and long coats who are termed lawyers, and perplex us like the labyrinths of the little person called Cupid, into whose clutches I was once betrayed.' He then sang a song that opened with the words 'Yea I fell into the pit of love / With a ti tum ti', designed to produce a comic effect, since Quakers were forbidden to sing by their sect. ${ }^{41}$ The song, in fact, proved very popular and was frequently encored in performance. Liston was praised by Hunt for the dry humour with which he played the part. ${ }^{42}$ Hunt was particularly impressed by the way in which Liston had divested the character of stage exaggeration, especially as Dibdin had left room for 'the caricaturing fancy of the actor'. He merely let the Quaker's absurdity speak for itself; unlike the stage Quaker: 'He neither walked in one undeviating straight line, nor glued his clasped hands to his bosom, nor conversed in the recitative of a parish clerk, nor rose at every emphasis upon his toe, nor ended all his speeches with a nasal groan. ${ }^{43}$ Hunt consistently praised the actors for bringing to life roles by authors whom he despised. Yet, whatever the shortcomings in the writing, the actor's performance would be impossible without the stimulus of the playwright, however sketchy or broad the outline.

Colman acknowledges the importance of the playwright in his prologue to the play, which was spoken by another popular comic actor, John Fawcett. Colman begins with an attack on contemporary critics, regretting that:

SOME Hypercritic cries, in ev'ry age,

'How rich the past, how poor the present Stage!'

Nevertheless, despite the critic's obsession with past glories and tendency to denigrate the theatre of the present, the judgement of audiences can always be trusted:

Still thrives our Stage, still seems there vigour in't;

For you smile here, while cynics scowl in print,

Plain proof, you think, whate'er our Stage may be,

Such critics infinitely worse than we!

\footnotetext{
39 New York Mirror (5 March 1831). $\quad 40$ Dibdin, Reminiscences, 1:395-6.

41 Thomas Dibdin, Five Miles Off; or, The Finger Post (London, 1806), 15-16.

42 Hunt, Critical Essays, $100 . \quad 43$ Ibid.
} 
Colman also comments on state censorship, although his comments here are more pragmatic:

When Liberal Censure fills the judgment seat,

We thank the hand that points, with gentle art,

The wholesome lancet to some morbid part...

It is the critic, with his 'hatchet', together with his insistence on following classical precedents, whom Colman most deplores. Surely audiences wouldn't flock to the theatres every night if they were purveying the sort of 'trash' of which the critics complain. In conclusion, Colman is clearly on the side of the actors and authors:

And, while a laugh or cry is to be had,

Authors and actors can't be very bad.

Oh! may this doctrine be allow'd tonight,

And be a laugh — broad laugh—your chief delight.

Look not with eyes of critical disdain,

But favour me who strives to entertain! 44

Colman's prologue is partly a mild attack on the censorship exercised by the Lord Chamberlain's Office-somewhat ironically, insofar as he was later to become Examiner of Plays for that very office-but it could also be seen as a much stronger rebuke to more outspoken critics such as Hunt. ${ }^{45}$

Eight years later, during the summer season of 1814, Liston and his wife were performing at the Lyceum Theatre-also known as the English Opera House-in the Strand. Harlequin Hoax was especially written for the company by Thomas Dibdin and proved an enormous hit. It concerns the reading of a new, and not very good, harlequinade, written by a persistent and pushy author, on whom Liston, Fanny Kelly, and their colleagues play a practical joke to teach him a lesson. Abundant in puns, the play is a satire on contemporary pantomime, while also providing an opportunity for a peep behind the scenes, spectacle on a small scale, and a magnificent fireworks display. Much of the satire is directed at the harlequinade, a form with which Dibdin had achieved many successes.

When the play opens, Patch the author (played by Edward Knight) announces he has written a pantomime for Mr Raymond, the manager. Raymond is not interested, but Patch has already distributed the parts, inevitably to unsuitable performers. When asked who is to play Harlequin, he is about to reply, when Liston is heard shouting off stage, 'Oh, but if I do, I'll be d-d.' As soon as he enters, Liston's first words are 'Mr Raymond - I have the highest veneration for my employers, a sincere regard for the welfare of their property, and no man could be more gratefully devoted to the public; but I beg leave to say, with the highest respect to you, Mr Manager, that if I play the part I'll be d—d.' He adds that he has

44 Dibdin, Five Miles Off, 3.

45 This may well be the Prologue to which Leigh Hunt refers when he writes 'Mr Colman attacked me in a prologue, which, by a curious chance, Fawcett spoke right in my teeth, the box I sat in happening to be directly opposite him. I laughed at the prologue, and only looked upon Mr Colman as a great monkey pelting me with nuts, which I ate.' Quoted in Archer \& Lowe, Dramatic Essays, p. xxvi. 
been too long on the stage 'not to know that Harlequin is the worst part in a pantomime - a thing of shreds and patches, without a single point to get applause except when he jumps and that is always done by somebody else'. ${ }^{46}$

Liston's professional pique is, however, a pose. In a side-whisper he adds that the actors are playing a hoax on the pretensions of $\mathrm{Mr}$ Patch. When the reading begins, Raymond undertakes Pantaloon and Patch the Clown. Thomas Dibdin builds into the dialogue an acknowledgement of Liston's popularity as a comic actor. Liston and Raymond pursue a piece of stage business that should end up with them striking the Clown, but instead they strike each other. This amuses the prompter, who says he is laughing at Liston. Liston replies, 'Very much obliged to you', and then addresses Raymond: '[B]ut, my dear sir, I beg ten thousand pardons; I fear I struck you rather forcibly.' Raymond tells him not to worry-it is a liberty he takes with his audience every night, to which Chatterly (the prompter) adds, 'And then who can help laughing?' 47

As Harlequin, Liston is told he ought to black his face or wear a mask. He is chagrined at this suggestion as the ladies will not be able to see his beautiful profile, another in-joke drawing on the grotesqueness of Liston's features. Among his other tasks will be to get his head stuck in the lamp case of a street lamp. The lamplighter is to pour a gallon of oil down his throat and stick a lighted wick in his mouth. (This is very close to one of the stunts carried out by Grimaldi in a harlequinade authored by Thomas Dibdin.) Then a crowd of drunken bucks arrive and knock his head to pieces, thinking they are breaking lamps. Liston's indignation continues to grow until he and Fanny Kelly finally put paid to Patch's ambitions.

Harlequin Hoax proved very successful. A light, good-humoured, satirical piece, it was perfect summer theatre fare and drew audiences right up until the end of the season. It presented popular actors, such as Liston and Fanny Kelly, in their everyday personas, enabling these performers to play theatricalized versions of themselves. It is unsurprising, perhaps, that Liston was praised for being 'the main beam of the piece'. ${ }^{48}$ And, once again, Thomas Dibdin proved that he could effectively parody a genre to which he had also contributed so many successful scripts.

That authors were indebted to actors rather than vice-versa is made abundantly clear in another piece by Thomas Dibdin, the comic opera Morning Noon and Night, performed at the Haymarket in 1822. Morris, the Haymarket manager, had just rejected Love Letters, a play by Thomas Dibdin, who began the new opera that same evening. It was submitted to Morris and Liston for approval. ${ }^{49}$ Dibdin refers in his Reminiscences to another occasion when he had to seek Liston's approval of one of his plays prior to Morris agreeing to perform it. 'I read to Mr Liston, while breakfasting at his own house, all that related to his part,' says Dibdin, 'and regretting (I was going to say reprobating) the practice of always sending authors for him to sit in judgment on,- Mr Liston said he would play the part. ${ }^{50}$ The plot is rather complicated and disconnected, although Dibdin had provided some good

\footnotetext{
46 Huntington Library, California, John Larpent Plays, 1814 MS.LA1824, Manuscript of Thomas Dibdin, Harlequin Hoax; or, A Pantomime Proposed, ff. 6-7.

47 Ibid., f. 8. 48 News (21 August 1814). $\quad 49$ Dibdin, Reminiscences, 2:236.

50 Ibid., 2:277. In fact Liston did not play the part in question, as Morris turned down the play.
} 
parts, such as Shark, a man with a guilty secret, played by Daniel Terry, and Liston's role, Lord Scribbleton, a man so foolish and self-important that he even insists his own father address him by his title rather than by his Christian name. $\mathrm{He}$ not only reads bad verses and cheap romances, but also writes them, thus providing Dibdin with an opportunity to satirize prevalent literary fashions and conventions. Lord Scribbleton bemoans the fact he lives in an unromantic country 'uncursed with caverns, barren of banditti, and where a man may travel from one end to the other of it, in the middle of the night, without seeing a single spectre'. ${ }^{51}$ His books, however, make up for this lack. They include The Deluded Wife, The Deserted Child, The Horrors of the Catacomb, The Murderous Muleteer, and The Petrified Pilgrim, the proceeds of which he gives to charity. He also writes verse, a sample of which is:

Peggy Webster was fairest of all that was fair, In the capital city of York,

Her brother cut capers, her father cut hair,

And her mother made hay with a fork. ${ }^{52}$

The summit of the satire is reached when Lord Scribbleton sings a comic song: 'Tis the fashion romances to read, / 'Tis the fashion romances to write'. ${ }^{53}$ The song satirizes all the machinery of Gothic horror: ladies dressed in white, bandits, vampires, robbers, ruins, wicked nuns, and prisoners. It became very popular and was frequently encored.

In the course of the play Lord Scribbleton sets out for an inn with his French servant, Baptiste, to view incognito the woman to whom he has been promised in marriage. Unfortunately, he stops at the wrong inn, from which arise a number of comic situations and misunderstandings. One traveller overhears him boasting of his 'Exploits in the Forest' and 'Murder of an Infant Heiress' and assumes he is a brigand, not an author. At the inn he is mistaken for a highwayman, wrongly apprehended on a charge of debt, and also mistaken for someone else's husband. The comedy relies on the old theme of the would-be adventurer getting entangled in a whole series of adventures, without ever really grasping what is happening. Liston was much praised for his performance: 'his sentimental coxcomb is an exquisite treat; there is a solemnity and deep feeling about his countenance which is truly laughable', ${ }^{54}$ wrote one commentator, while the Theatrical Observer, which thought little of the play, conceded that Liston 'contrives to throw in such looks and such attitudes, that the sketch is heightened to a very ludicrous pitch. His directions to his servant Baptiste at the Bush Inn, to inspect his apartments, to ascertain whether there are any trap-doors — any dead men in closets—or any pillows or bolsters stained with blood, and Liston's mysterious air in entering the room, after his romantic brain had supposed an adventure to be at hand, were truly amusing.' 55 It seems that, once again, the author has provided a sketch for the actor

\footnotetext{
51 Thomas Dibdin, Morning, Noon and Night; or, The Romance of a Day (London, 1822), 9.

52 Ibid., $10 . \quad 53$ Ibid., 26.

54 Unidentified clipping, attached to Haymarket Playbill (9 September 1822).

55 Theatrical Observer (11 September 1822).
} 
to develop, embody, and bring to life. While not providing Liston with any of his greatest roles, Thomas Dibdin still created parts tailored to his particular talents.

\section{CONCLUSION}

Thomas Dibdin's career did not always progress smoothly. He was clearly a competent stage manager and a prolific author, but he faced hostility inside as well as outside the theatrical profession. He encountered particular difficulties in the early 1820s when working for Robert William Elliston at Drury Lane and David Morris at the Haymarket: Elliston eventually sacked him as Drury Lane stage manager; Morris regularly commissioned plays from Dibdin and then rejected them. Dibdin ascribes his difficulties to the influence of James Winston at both theatres. ${ }^{56}$ Winston is certainly unsympathetic to Thomas Dibdin in his Diaries, criticizing the text of Dibdin's The Chinese Sorcerer (1823), while praising its effective staging. ${ }^{57}$ Henry Crabb Robinson, who saw this production on 16 April 1823 , seems to concur: '[T] he scenery was so beautiful that I actually cared nothing for the execrable stuff of words by which it was accompanied. ${ }^{58}$ On 29 April Winston recorded that:

T. J. Dibdin put up a notice in the Green [Room] requiring the performers in The Chinese Sorcerer not to speak more than was writ down for them. This they did literally, and the piece [went] off very dully — their jokes being the only ones in the piece. They sent an answer to Dibdin nearly as follows- $\mathrm{Mr}$ Elliston gave the performers a carte blanche to say what they please as they could say nothing worse than what [he] had given them. They would do that [which] would prevent the author sending them such another piece, it being beneath their talents, etc., etc. ${ }^{59}$

A few weeks later, on 17 May, Winston wrote that Dibdin 'talked much about himself in the Green [Room]. Said he was next to Mr Colman and he should soon find his proper place-not been treated well here... Twenty years ago Dibdin was a great man at Covent Garden, etc., etc.' ${ }^{60}$ Even if Thomas Dibdin's self-estimation as second only to Colman the Younger is questionable, it seems likely that he was correct in his assumption that Winston was hostile to his presence at both Drury Lane and the Haymarket. As Michael Burden indicates in Chapter Three in this volume concerning the elder Charles Dibdin's experiences at the Royal Circus, personality clashes and rivalry remained a continual thorn in the side of the theatrical collaborator.

Throughout his career Thomas Dibdin wrote a large number of serviceable melodramas, comedies, operas, and pantomimes, providing roles that actors could develop creatively and, through Harlequin and Mother Goose, fostering the career of

\footnotetext{
56 Dibdin, Reminiscences, 2:281.

57 Alfred L. Nelson and Gilbert B. Cross (eds), Selections from James Winston's Diaries 1819-1827 (London: Society for Theatre Research, 1974), 65.

58 Eluned Brown (ed.), The London Theatre, 1811-1866: Selections from the diary of Henry Crabb Robinson (London: Society for Theatre Research, 1966), 101.

59 Nelson and Cross, Diaries, 66.
} 
Joseph Grimaldi and seminal developments in English pantomime. As an author he endeavoured to supply theatres with the sort of plays they required and actors with parts that fitted them. In any non-literary history of the nineteenth-century theatre he is and remains a significant figure, a far cry from Hunt's 'scribbler' whose major achievement had been to debase the taste of the town. A review of his Reminiscences in the New Monthly Magazine provides a fairer assessment of his qualities:

Whatever estimate may be formed of his merits as a dramatic writer, the success of many of his pieces which still keep possession of the stage, entitle the life of the writer of two hundred plays to very respectful attention-especially when we consider the very great effect which even the farce of a season has upon manners-the colouring which it gives to conversation and habits of expression-and the way in which the stage modifies the ordinary language and ordinary ideas of the numerous class of persons who frequent the theatres. ${ }^{61}$

The London Magazine takes the discussion further, responding in its review of Dibdin's Reminiscences to the pressures he was under, often for reasons of profit rather than artistry, to rework his plays:

Not only is the character of the piece affected by the interested speculations of the playwright, but in the process of manufacturing is greatly modified by those of the proprietor and performers. Mr. Dibdin's pieces, in the course of reading and rehearsing, appear to have suffered innumerable alterations and additions, rendered necessary by the views of the proprietor, or the jealousy of actors. The dramatist seems as often to have worked upon their suggestions, as to have been guided by any original conceptions of his own. His business was to fit them with parts, and if the parts did not $f i t$, the pieces were sent home to be altered. ${ }^{62}$

Like those of other contemporary playwrights, such as John Poole and William Thomas Moncrieff, Thomas Dibdin's final years were poverty-stricken. In 1833 he dedicated a publication entitled Last Lays of the Last of the Three Dibdins, containing 150 new songs and poems and 150 selections from published and unpublished productions, to Edward Bulwer Lytton, praising his bill in favour of the rights of dramatic authors. Had such a bill been passed thirty years earlier, claimed Dibdin, 'the writer of this would, in his decline, have possessed a very considerable income', while he lambasted all 'those gentlemen managers, prompters, and copyists, whose assumed prerogatives, perquisites, and pilferings, by private sale and resale of his manuscripts, have, for years, monopolized all such profits exclusively for themselves'. ${ }^{63}$

Thomas Dibdin represents the problems faced by playwrights in a period when the dramatic text was not sacrosanct but merely one aspect of a collaborative approach to creating performance. The text is the blueprint, not the finished article, and Dibdin would have been keenly aware of this. Popular genres such as pantomime needed some form of text, but this was merely a template for a much more complex activity requiring an input of skills and original ideas by a range of theatre workers. Melodrama was often formulaic and dependent on spectacular effects. Theatre was a commercial

\footnotetext{
61 New Monthly Magazine 19/1 (1827): 580.

62 London Magazine 8 (June, 1827): 230

63 Thomas Dibdin, Last Lays of the Last of the Three Dibdins (London, 1833), iii.
} 
enterprise driven by economic imperatives. While a dramatist might occasionally receive a large sum for a specific play, the rewards were often paltry compared with the sums pocketed by management and leading actors. As John Russell Stephens indicates, 'Dramatic authorship was never an easy profession and for much of the century provided neither security nor status. ${ }^{64}$ Many dramatists learned their trade from direct involvement in the theatre as actors or stage managers, some were also theatre managers, and the majority were concerned to generate income rather than literary fame. The ultimate text was the performance, the success of which depended on a favourable response from spectators. Thus the recognition for which Dibdin and his fellow dramatists struggled was not related to the value of their texts in literary terms, but to their value as a part of the collective endeavour to enable effective and commercially successful theatrical productions.

64 John Russell Stephens, The Profession of the Playwright: British Theatre 1800-1900 (Cambridge: Cambridge University Press, 1992), 2. 


\title{
11
}

\section{'Each Song Was Just Like a Little Sermon' Dibdin's Victorian Afterlives}

\author{
Isaac Land
}

The memory of Charles Dibdin flourished in the Victorian era. This went well beyond the occasional revival of his songs, and the entry of a few selected works into the standard repertoire of national favourites. Sailors who wrote memoirs recorded how their shipmates would ask for 'a Dibdin'. ${ }^{1}$ The indefinite article suggested that Dibdin's sea songs had been received as a whole genre unto themselves. As late as 1853, the Illustrated London News did not know how to refer to their contemporaries who penned sea songs and nautically themed plays except as 'our Dibdins'. Two decades later, a song appeared in Punch attributed to 'the ghost of Charles Dibdin'. ${ }^{3}$ In the 1890s, Gerard Cobb was called 'the Dibdin of the Army' when he set Rudyard Kipling's Barrack-Room Ballads to music. ${ }^{4}$ There is at least one instance of an adjective: 'Dibdinish'. 5

In another measure of the enduring affection for Dibdin, festivals were held to raise funds for a statue of the composer at Greenwich. This marked an important transition point in the process of repackaging Dibdin as primarily a loyalist songwriter on naval themes, although as Cox Jensen points out in Chapter Seven of this volume, these were hardly representative of his overall output, and even in this narrow arena, he had many competitors in his lifetime. Some enthusiasts signed the subscription lists with appropriate pseudonyms such as 'Black Ey'd Susan' and 'A Lass who loved a Sailor'. 'A Jack Tar, all his Rhino but me at an end' gave $\mathfrak{E} 11$ s. to the monument fund ('rhino' being a term for money that would have been familiar to admirers of Dibdin lyrics). ${ }^{6}$ Beginning in 1841, the Handel enthusiast and professional opera singer Henry Phillips (1801-76) sent out a series of calls for reminiscences and appreciations of Dibdin. ${ }^{7}$ Dozens of responses survive

1 Land, War, 112-15.

2 'Sketches of Stage Favourites: Mr. T. P. Cooke', Illustrated London News (15 October 1853): 319.

3 Punch (11 December 1875): $240 . \quad{ }^{4}$ Scott, The Singing Bourgeois, 172.

5 Punch (24 September 1892).

6 Subscription list, 'National Monument to the Memory of the Late Charles Dibdin', Harvard Theater Collection MS Thr 198, box 3 (hereafter HTC).

7 Henry Phillips, Musical and Personal Recollections during Half a Century, 2 vols (London, 1864) (hereafter Phillips) is valuable; his project to collect the testimonials is discussed in 2:12-20. Phillips's materials and correspondence from the 1840 s revival wound up in the HTC. 
in the Harvard Theatre Collection. Several correspondents remark on Phillips's own role as a keeper of the flame, both as a skilled performer of Dibdin's works and as an advocate for seeing a complete, official version of the Dibdin corpus into print. The Songs of Charles Dibdin, a two-volume compilation that first appeared in 1842, contains an expression of gratitude for Phillips's help. Some of the reminiscences - in handwriting shaky with age or infirmity—are from ordinary people who had heard Dibdin perform when they were children. One was even taken backstage to meet the great man. Others, in a more analytical spirit, discuss how his songs helped win the war, a theme that has been revived by modern scholars of patriotic music and theatre. ${ }^{8}$ Charles Taylor wrote, 'Certainly no writer of that day contributed so much to the good of his country-Each song, was a Sermon, for the simple beauty of his language was such, that it could not fail to excite all minds to admiration, and accompanied by his touching composition had more affect $[s i c]$ upon the Navy, than any arguments set forth from the Pulpit.'

In this chapter, I consider Dibdin's Victorian afterlives under three different headings, each prompted by a question. First, how did the Victorians square Dibdin's questionable personal life and somewhat rough-hewn language with their expectations of moral uplift? Second, what did it mean to present Dibdin as an object of reverence and serious study? If he was an English 'bard', a 'genius', and one of the defining landmarks in the culture of the Napoleonic era, how would this shape the publication and performance of his works in the Victorian period? And third, how did nostalgia for the era of wooden warships trigger a fresh wave of Dibdin appreciation in the closing decades of the nineteenth century? All of these enquiries shed light on Cox Jensen's contention that the capacity of Dibdin's songs 'to assimilate change demonstrates [their] inherent versatility'. ${ }^{10}$

\section{MUSIC AND MORALS}

Asked, in the final year of his life, to contribute something for a concert in honour of his father, Thomas Dibdin penned a somewhat strained rewrite of 'Poor Jack':

To him, who ne'er yet breathed a line which You

Might not approve; and this fact was his pride!

His Harp's speaking melody ne'er owned the strain

Which could poison convey to the ear,

Make semblance of pleasure a passport to pain,

Or caused ruin'd beauty a tear;

8 Jim Davis, 'British Bravery, or Tars Triumphant: Images of the British Navy in Nautical Melodrama', New Theatre Quarterly 4 (1988): 122-43; Jacky Bratton, Acts of Supremacy: The British Empire and the Stage, 1790-1930 (Manchester: Manchester University Press, 1991). I have discussed this from a somewhat different angle in Land, War, 77-104.

9 HTC: Charles Taylor, 12 August 1842. On the issue of sermonizing and proper tone, see also Cox Jensen, Chapter Seven of this volume.

10 Chapter Seven of this volume, 133. 
If mirth and sound moral commingled may claim

Recollection, his Muse ne'er will Lack

The wreath of True Genius, which justly-earn'd Fame

Shall entwine for the Bard of 'Poor Jack'. ${ }^{11}$

Thomas Dibdin's tone seems slightly defensive-who was suggesting that his father's lyrics might convey poison to the ear? As early as the 1840 s, what might be called the Music and Morals question-after the influential 1871 volume by Rev. H. R. Haweis-hampered supporters' efforts to elevate Dibdin to a canonical position. Haweis sums up an attitude that was already widespread in some Victorian circles when he denies that the ideal composer was necessarily an unbridled spirit: 'His profession, rightly exercised, does not lead to the unbalanced excitement of sensuous emotions... but to the orderly education and discipline of emotion, which is a very different thing.' 12 In this vein, Haweis instructs his readers that 'Beethoven was not only severely moral and deeply religious, but... his ideal of art was the highest', and even Mozart 'was a man of the most singularly well-balanced character'. 13

This was not a standard that Dibdin could live up to, unless (as, perhaps, in the case of Mozart) one were willing to take liberties with the biographical evidence. In a sketch that bears on David Kennerley's argument in Chapter Five of this volume, George Hogarth conceded that 'Dibdin may be added to the numerous illustrations of the maxim, that the character of an author is not to be gathered from his works. In the nearest and dearest relations of life, his conduct was at total variance with the sentiments to which he was in the daily habit of giving expression. ${ }^{14}$ However, he denied that there was anything insincere about Dibdin's songs, which formed the strongest evidence of the composer's noble core beneath the tarnished exterior. 'That the principles of religion and morality existed in his mind, and that he was of a kindly and benevolent nature, cannot be doubted. These features are stamped upon his works in characters not to be mistaken. Language so full of truth and nature, and so evidently the outpouring of the heart, could never have been dictated by hypocrisy, or the mere conventionality of authorship. ${ }^{15}$ In a letter to Henry Phillips, Edward Taylor, who taught music at Gresham College, also defended Dibdin against the charge of hypocrisy:

I remember Dibdin; and I never shall forget the extraordinary effect that he produced with a very scanty and not very attractive voice, nor how completely he identified himself with any sentiment to which he gave utterance, so that it seemed like the spontaneous overflow of a kind and generous heart aided by a vivid imagination, than a prepared and got up performance... if some of our modern so-called song writers would endeavour to take a leaf out of his book, and remember that the first and chief ingredient in a song is its melody, their compositions would be a little more palatable than they are. [Here he addresses Phillips directly:] You know, for you have often proved, the effect of Dibdin's melodies, when, unsupported by accompaniment of any

\footnotetext{
11 HTC. 12 Hugh Reginald Haweis, Music and Morals (4th edn, London, 1873), 87.

13 Ibid., 91, $92 . \quad 14$ Hogarth, 1:xxviii. ${ }^{15}$ Ibid., 1:xvii.
} 
sort, they have made their appeal to the sympathy of an audience, and you know that the appeal is seldom if ever made in vain. ${ }^{16}$

Like Hogarth, Taylor (echoing Wordsworth's famous description of poetry as the 'spontaneous overflow of powerful feelings') represents Dibdin's songs as an outpouring or effusion of the composer's authentic inner spirit, rather than a manipulative tugging at the listener's heartstrings. Similarly (in another echo of Kennerley's chapter), a rumour circulated that Dibdin had lost his pension because he had criticized the government's treatment of veterans. Hogarth was aware of this story, but dismissed it as apocryphal. ${ }^{17}$ Yet it resurfaced in the 1880 s, suggesting that the story fulfilled a need: if Dibdin could not represent virtue in one sense, perhaps he could in another, showing courage on behalf of the very sailors lionized in his songs. ${ }^{18}$

Setting aside the question of the composer's personal and indeed public life, the tone and vocabulary of his lyrics also worried some Victorians. The Hampshire Advertiser acknowledged that, while forceful, these often verged on the unacceptable: 'His most successful painting is done by very broad handling, a thick brush, and a coarse touch.' ${ }^{19}$ Hogarth, introducing the compilation of 1842, figured this positively, writing that Dibdin's sea songs were 'bold and masculine, without the slightest rudeness or vulgarity; and they hence afford delight to the simplest as well as to the most cultivated taste'. ${ }^{20}$ An undated newspaper clipping preserved in Phillips's papers entitled 'The Songs of Charles Dibdin' addressed the charge that Dibdin's lyrics were too 'low' for polite consumption:

Never concealing, and sometimes half-justifying or extenuating the irregularities of the classes whom he chiefly addressed, the whole tendency of his songs is to strengthen in the homeliest and the least obtrusive manner, the peculiar virtues of their station-honour, valour, mercy, friendship, and virtuous love; while incidentally, and without the remotest attempt at teaching, the ill consequences of an opposite conduct are shown.

The author goes on to quote a writer in the Harmonicon from 1824, who stated, 'Had Dibdin written merely to amuse, his reputation would have been great, but it stands the higher because it is always on the side of virtue.' Interestingly, thinking especially perhaps of songs such as 'True Courage', the later essayist takes this a step further by remarking on Dibdin as a nobly restrained war poet: '[T] hough Dibdin was a man of his age ...yet it was a great merit, that in a period of unusual excitement, he cheered its followers on as brave, but humane men; as performing a duty to their country, not as gratifying any vindictive passion of their own.'

In a letter to Phillips, one H. Bellamy wrote that 'his [Dibdin's] works taken altogether form such a compendium of morality and good feeling as can scarcely be equalled by any other contributor to the lyric art'. ${ }^{21}$ This was a step beyond praising his earnest, unaffected style. Was Dibdin being presented as the analogue of

16 HTC: Letter from Edward Taylor, 8 December 1841. 17 Hogarth, 1:xxv.

18 Musical World 69 (3 August 1889). 19 Hampshire Advertiser (5 September 1863).

${ }^{20}$ Hogarth, 1:xxxii. $\quad 21$ HTC: Letter from H. Bellamy, 30 November 1841. 
Hannah More, whose Cheap Repository Tracts had preached against revolution in the 1790s, or perhaps as the progenitor of what Derek Scott has called improving ballads'?22 If so, it would have been an ironic fate for the man condemned by More and her colleague Gilpin for his 'loose, profane, and corrupt' verse, and who-as Cox Jensen has shown in this volume-was second-guessed even by contemporary admirers for his slang and irreverent language. ${ }^{23}$

Dibdin's choice of words remained objectionable to some Victorian ears. In his autobiography, Phillips observes that Dibdin enthusiasts often bowdlerized the very songs that they praised. In 'Poor Jack' the line 'Why, what a damn'd fool you must be!' became 'Why, what a great fool you must be!' In 'Wapping Old Stairs' the Victorians replaced a reference to 'trousers' with 'waistcoat'. ${ }^{24}$ Phillips chastised such 'refined' and 'prudish' vocalists, but it would be a losing battle; according to Scott, by the 1870s, Dibdin had become too lively and vulgar for the drawing room. ${ }^{25}$ O. F. Routh had a different solution, retaining Dibdin's music but jettisoning the lyrics entirely. His Temperance Dibdin, a collection of twenty songs that sold for eight pence, was advertised with the claim that it transformed 'this priest of Bacchus into the apostle of temperance'. ${ }^{26}$

Victorians who relished Dibdin's lyrics and wished to retain them liked to argue that a missionary was entitled to adopt mannerisms and language that would work best with his intended audience. When speaking to sailors, it made sense to couch one's remarks in terms of nautical bravado. This suggests a comparison to the Bethel Movement, a nineteenth-century missionary endeavour that refurbished old ships into floating chapels in various harbours, and encouraged sailors who had turned to religion to preach to their fallen brethren in a language that they would understand. ${ }^{27}$ Hogarth best articulated this position. He argued that Dibdin, through his intuitive grasp of their nature, had inspired sailors to be their best selves:

Dibdin's pictures of the sailor's character, and the sailor's life, though highly coloured and embellished, are true to reality in their essential features... It is the embellished truth of Dibdin's pictures which has made them act so powerfully on the class they represent. Were they coarse and literal copies, the originals would turn away in anger and disgust, from a looking-glass which reflected their deformities with so unpleasing a fidelity. Were they mere fancy-pieces, they would be neither understood nor cared for. In the Jack Ratlin or Tom Bowling of Dibdin, the sailor recognizes a brother-sailor-a being like himself, but nobler and better than himself, whom he would gladly resemble more fully, while $[s i c]$ he feels himself capable of doing so... That this is no imaginary picture has been vouched [for] by those who are most conversant with nautical life.

22 Dibdin is much discussed in Bratton, The Victorian Popular Ballad and Scott, The Singing Bourgeois. For 'improving ballads', see Scott, The Singing Bourgeois, 137.

${ }_{23}$ Hannah More, The Two Shoemakers. In Six Parts (London, c. 1800), 88 fn.

24 Phillips, 2:17-18. 25 Scott, The Singing Bourgeois, 158, 172.

26 Musical World (2 March 1872): 146.

27 Roald Kverndal, Seamen's Missions: Their Origins and Early Growth (Pasadena, CA: William Carey Library, 1986). 
They have a thousand times borne testimony to the fact, that these happy effects on the character of the British sailor have been mainly caused by the Songs of Dibdin. ${ }^{28}$

A different approach to Hogarth's point may involve a reappraisal of the great majority of Dibdin listeners who were not sailors at all. We might conclude that Dibdin offered a sentimental and unchallenging version of plebeian life-but had his songs been entirely respectable, would they have been as exciting, as charming, or as popular? Raymond Williams's remark that Charles Dickens was the characteristic novelist of the overheard snatch of speech on the metropolitan street is of interest here. ${ }^{29}$ Dickens's occasional use of a Dibdin lyric showed an awareness of, and perhaps an affinity for, the songwriter. It would be difficult to sustain a pointby-point comparison between the two authors, but within the constraints of his genre, Dibdin is remembered, above all, for having given a voice to certain kinds of marginal characters. If, as a moralist, his tastes ran to the saccharine, the affection for his diamond-in-the-rough characters would not have endured if the 'rough' had not contained a little genuine grit.

\section{TAKING DIBDIN SERIOUSLY}

In 1841, Dickens's illustrator, George Cruikshank, supplied the pictures to go with Thomas Dibdin's compilation Songs Naval and National of the late Charles Dibdin. The following year, G. H. Davidson published the more ambitious and comprehensive Songs of Charles Dibdin, Chronologically Arranged with Notes, Historical, Biographical, and Critical; and the Music of the Best and Most Popular of the Melodies, with New Piano-Forte Accompaniments, beginning with a long, appreciative introduction by Hogarth. Pairing Dibdin with the illustrator of Oliver Twist showed some insight into the personalities and aptitudes of both men; but the Davidson volumes (dedicated to Prince Albert) adopt an altogether loftier tone, supplying massive footnotes to gloss every historical event mentioned in the songs. This footnoting project creates a number of incongruous moments, reaching a height of absurdity when a slight and generic patriotic piece, 'The Battle of Corunna', is reproached for quite overlooking the fact that Corunna had been a defeat. The footnote quotes at length from battle dispatches and even cites scholarly volumes such as Napier's History of the Peninsular War. This unlikely essay is far longer than the song, nearly crowding Dibdin's lyric off the page. This leads to a bizarre juxtaposition on page 421, where the dense historical narrative continues, topped by the next song, one of Dibdin's most frivolous pieces, 'Pomposo'. ${ }^{30}$

What is at work here? It is unclear who supplied the footnotes, although the note to 'The Preservation of the Braganzas', another hastily improvised patriotic piece celebrating the successful escape of the Portuguese royal family to Brazil, offers a

\footnotetext{
28 Hogarth, 1:xxx-xxxi.

29 Raymond Williams, The Country and the City (London: Chatto \& Windus, 1973). For Dibdin's ventriloquizing of 'typical' voices, see also Harriet Guest in Chapter Eight of this volume, 138-41.

30 Hogarth, 2:418-22.
} 
hint of the vision behind the project. The long gloss begins, 'The events referred to are altogether of so remarkable a character, that we think we shall be pardoned, particularly by our younger readers, if we notice them at some length. ${ }^{31}$ Given that Dibdin did not go in for detailed narratives — this was scarcely 'The Midnight Ride of Paul Revere'-it is hard to imagine young readers using Dibdin as a schoolbook. The notes continue to fault him for his inadequacies as an educator, however, factchecking a song entitled 'Naval Victories', mercilessly enumerating all of Dibdin's historical errors. The note concludes, '[I]f the song has little merit as a piece of chronology, it has still less as poetry. ${ }^{32}$ This marks a sharp departure from the tone set by Hogarth's preface at the beginning of the first volume, which labels Dibdin a 'genius'. ${ }^{33}$ Hogarth also deploys the term 'bard', showing that - for him, at leastthe word was not merely a fancy synonym for poet or songwriter, but a deliberate evocation of the ancient world: 'Dibdin united in his own person the characteristics of the bards of the olden time. He gave to the world, through the medium of his own recitations, his own poetry and his own music. In modern days he is absolutely without a parallel.' 34 Robert Burns, by this definition, is explicitly of a lesser status than Dibdin, as he had written poetry, but not the music to go with it.

As inconsistent (or incoherent) as the Davidson volumes are, they belong to a trend of the 1840s: Dibdin is presented as serious, edifying, and uplifting. Even the irate footnotes to the Davidson edition suggest that Dibdin was now expected to serve a higher purpose than that of a mere composer of toe-tapping ditties. This process may also be seen in the way that Dibdin was performed. Phillips boasted that he rendered the lyrics and the notes exactly as the master had written them, remarking in his autobiography that he 'sang as near the manner of Dibdin, as any one I believe since his time, having been taught to do so by my mother, who knew him intimately'. ${ }^{35}$ Only a philistine would sing a Dibdin song as a round, making the lyrics hard to hear, and losing the conversational tone of the original. At the Hanover Square Rooms on 2 March 1844, Phillips offered 'An Hour with Dibdin and a Miscellaneous Act'. A promotional poster, reproduced in Figure 11.1, shows these words emblazoned against a colourful Union Jack backdrop. The 'Hour with Dibdin' was a benefit concert for the Shipwrecked Fishermen and Mariners Benevolent Society. The Hanover Square Rooms were often used for prestigious charity events, for example on behalf of refugees displaced by political unrest on the Continent, at times with royalty and society figures in attendance. ${ }^{36}$ Admission to the 'Hour with Dibdin' would be 2s. 6d., or 3s. 6d. for a reserved seat.

What sort of person might turn up at the Hanover Square Rooms at half past eight on a Saturday evening? A stone's throw from Regent Street and Oxford Street, Hanover Square was London's bastion of serious concert going. Its habitués liked to contrast their serious interest in music against both the crudity of the popular

\footnotetext{
31 Ibid., 2:369-71, quoted 369. 32 Ibid., 2:229-30.

33 Ibid., 1:xv. For the term 'genius', see also Musical World 62 (20 September 1884): 596.

34 Hogarth, 1:xxix. $\quad 35$ Phillips, 2:17.

36 Frank K. Prochaska, 'Charity Bazaars in Nineteenth-Century England', Journal of British Studies 16 (1977): 62-84.
} 


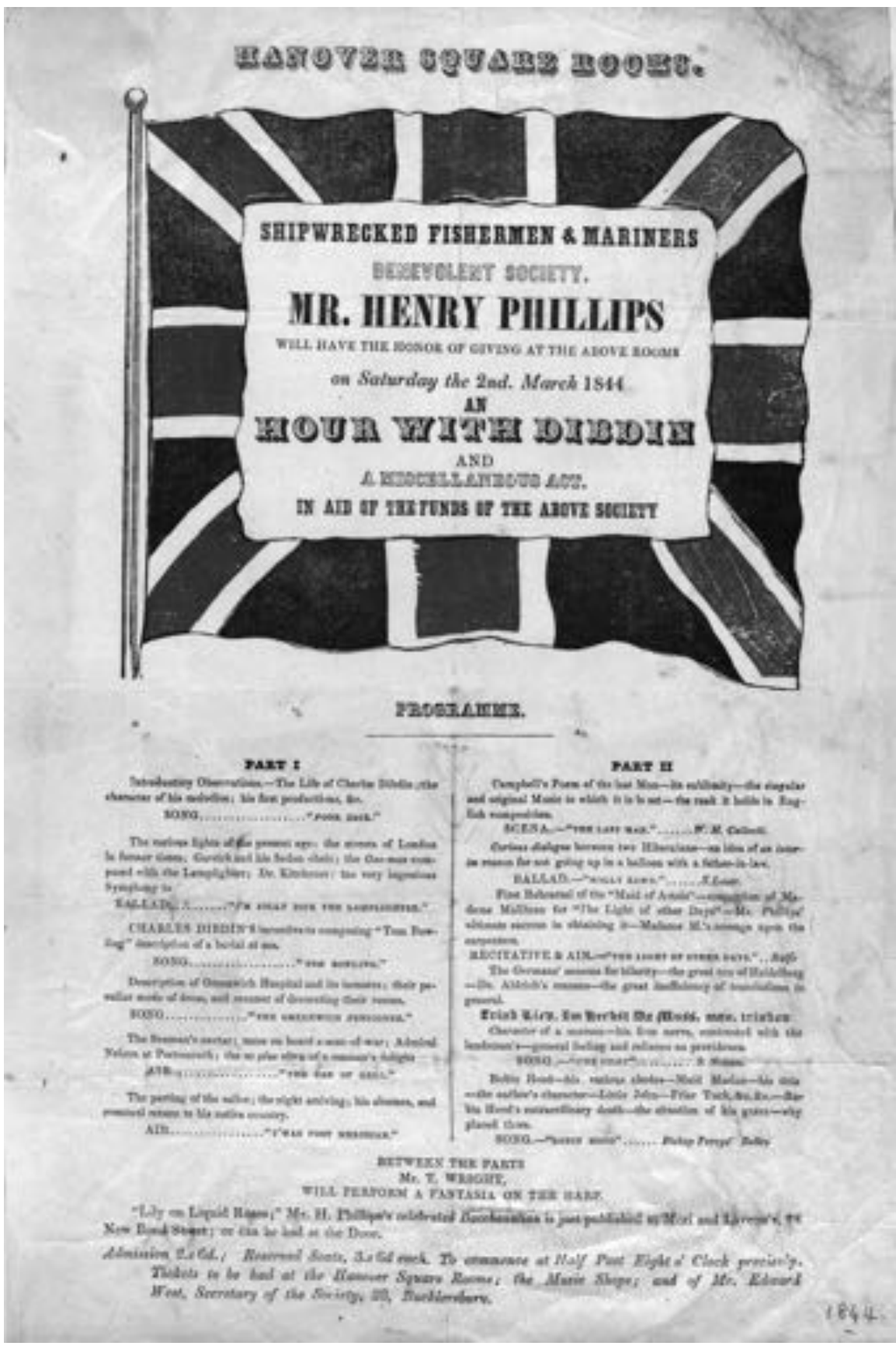

Figure 11.1. Promotional poster for An Hour with Dibdin and a Miscellaneous Act. London, 1844. Hand-coloured engraving. MS Thr 1981 43-144, Houghton Library, Harvard University. 
performance halls and the empty virtuosity of the aristocratic salons. Christina Bashford has written of the emergence of 'concentrated listening and a general seriousness of purpose' in the 1830 s and 1840s. ${ }^{37}$ Some performances had an almost academic aspect, as the audience brought a score to follow. A semi-circular seating arrangement enabled a 'music so nicely delicate in all its parts' to reach the ears of all the ticketholders. ${ }^{38}$ Liszt, Berlioz, and Mendelssohn would perform there in the 1840s. While it is true that the cultural politics of what counted as 'classical music' remained somewhat uncertain in this period-the term itself was only beginning to emerge- it is fair to say that Dibdin's songs were never performed in such an atmosphere in his lifetime. ${ }^{39}$

On 2 March, the evening's programme was as shown in Table 11.1. Between the parts, a 'Mr. T. Wright will perform a fantasia on the harp'.

Some reviewers remarked simply that the programme showed Phillips's versatility. Cross-referencing the songs in the 'Miscellaneous Act' with his autobiography reveals that two of the songs in Part Two had been turning points in Phillips's own career. 'The Last Man' had been written expressly for him to perform-a sign that he had arrived as a singer - and when he sang 'The Light of Other Days' in Balfe's opera The Maid of Artois (1836), the audience demanded no fewer than three encores. ${ }^{40}$ Yet a closer look at this programme shows a coherent vision and a process of selection that went beyond personal favourites or crowd-pleasers. Most obviously, all but one of the Dibdin pieces were sea songs. Part One is nostalgic on at least two levels: for Dibdin's era in London life, but also for Nelson's sailors just as the age of steam threatens to displace them-and they are dying off. Yet positioning Dibdin as of his time, a quaint period piece, is not the complete story. There are also the resonances between Parts One and Two.

Phillips's 'Miscellaneous Act' begins with 'The Last Man', a solemn song about the apocalypse:

The Sun's eye had a sickly glare,

The Earth with age was wan,

The skeletons of Nations were

Around that lonely man!

Today, this song seems to have disappeared into the obscurity from whence it came. However, Phillips's programme notes draw attention to the singular, sublime qualities of 'The Last Man', its originality, and the 'rank' it holds among English compositions. Opening Part Two with this piece placed Dibdin in rarefied company. Phillips followed the apocalypse with some comic relief in the form of 'Molly Bawn', replete with Irish-isms. (It first appeared in the comic operetta A Paddy Whack in Italia.) The bold young lover Rory O'Moore presses on:

\footnotetext{
37 Christina Bashford, 'Learning to Listen: Audiences for Chamber Music in Early Victorian London', Journal of Victorian Culture 4 (1999): 25-51, 28.

38 Ibid., 34.

39 Derek B. Scott, 'Music and Social Class in Victorian London', Urban History 29 (2002): 60-73.

40 Phillips, 1:217-18, 229-30, 279; 2:39.
} 
Table 11.1 An Hour with Dibdin and a Miscellaneous Act concert programme, Hanover Square Rooms, 2 March 1844.

Part One
Introductory Observations._-The Life of Charles
Dibdin; the character of his melodies; his first
productions, \&c.
Song... 'Poor Jack'
The various lights of the present age; the streets of
London in former times; Garrick and his
Sedan chair; the Gas-man compared with the
Lamplighter; Dr. Kitchener: the very ingenious
Symphony to Ballad... 'I'm Jolly Dick the
Lamplighter'
Charles Dibdin's incentive to composing 'Tom
Bowling'; description of a burial at sea.

Song... 'Tom Bowling'

Description of Greenwich Hospital and its inmates; their peculiar mode of dress, and manner of decorating their rooms.

Song... 'The Greenwich Pensioner'

The Seaman's nectar; mess on board a man-ofwar; Admiral Nelson at Portsmouth; the ne plus ultra of a seaman's delight.

Air... 'The Can of Grog'

The parting of the sailor; the night arriving; his absence, and eventual return to his native country.

Air...'T'was Post Meridian'

\section{Part Two}

Campbell's Poem of the last Man-its sublimity-the singular and original Music to which it is set-the rank it holds in English composition.

Scena._-'The Last Man' ... W. H. Callcott

Curious dialogue between two Hibernians - an idea of an interim reason for not going up in a balloon with a father-in-law.

Ballad._-Molly Bawn'... S. Lover

First rehearsal of the 'Maid of Artois'contention of Madame Malibran for 'The Light of other Days'-Mr. Phillips' ultimate success in obtaining it-Madame M.'s revenge upon the carpenters.

Recitative \& Air-'The Light of Other Days'... Balfe

The Germans' seasons for hilarity - the great tun of Heidelberg-Dr. Aldrich's reasons - the great inefficiency of translations in general.

Trink Leid . . . Em Herbst Da Muss, man, trinken'

Character of a seaman-his firm nerve, contrasted with the landsman's — general feeling and reliance on providence.

Song.-_The Pilot' ... S. Nelson

Robin Hood-his various abodes-Maid Marian-his title-the outlaw's characterLittle John-Friar Tuck, \&c. \&c.-Robin Hood's extraordinary death-the situation of his grave-why placed there.

Song.—_Robin Hood' ... Bishop Percy's Relics

The pretty girls were made for the boys, dear,

And may be you were made for mine.

The third song returns the tone to a deathly solemnity:

The very Ivy on the ruin,

In gloom full life displays;

But the heart alone sees no renewing,

The light of other days. 
The composer of 'The Light of Other Days' was Balfe, who would soon have many parlour or drawing room favourites to his credit, such as his setting of Tennyson's 'Come into the Garden, Maud'.

It is worth considering how the various songs in the supposedly miscellaneous Part Two worked to situate Dibdin, complement him, or show off his best qualities. The lighter songs in Part Two are frivolous in the extreme. 'Molly Bawn' is lusty without any ennobling challenge such as self-sacrifice or a long separation. The German drinking song celebrates drinking in the absence of any context. By contrast, Dibdin's 'The Can of Grog' engages directly with grace under pressure:

$$
\begin{aligned}
& \text { Blest with a smiling can of grog, } \\
& \text { If duty call, } \\
& \text { Stand, rise, or fall, } \\
& \text { To fate's last verge he'll jog. }
\end{aligned}
$$

If empire was a test of character, drinking helped sailors rise to that challenge:

$$
\begin{aligned}
& \text { For while the grog goes round, } \\
& \text { All sense of danger drown'd, } \\
& \text { We despise it to a man. }
\end{aligned}
$$

Meanwhile, the exceptionally grim, religious, and melancholy pieces in Part Two brought out and emphasized Dibdin's stanzas that evoked storm, strife, religious thoughts, and the afterlife.

What of the Union Jack plastered across the concert programme? The inclusion of 'Robin Hood' to close Part Two harks back to another of Phillips's great preoccupations, the lack of appreciation of English musical traditions. In his autobiography, he inveighs against the 'brainless prejudice' in favour of German or Italian composers and singers. Phillips felt that it was time to raise the 'national musical flag', even if his friends on the Continent might jibe that English music consisted of nothing but 'roast beef and guineas'. The final project discussed in his autobiography was his role in founding the English Glee and Madrigal Union. ${ }^{41}$ When he critiqued the overuse of German musical styles and fashions in his own day, Phillips remarked, 'Fancy the naval songs of Charles Dibdin in such extraneous keys. '²

After his performance at the Hanover Square Rooms, Phillips took 'An Hour with Dibdin' on a long tour of the United States. This turned out to have been an unfortunate business decision. The publisher of Dibdin's songs in the US had persuaded him that a market existed for this sort of entertainment, but New York City audiences were puzzled and even offended by what sounded to them like a gratuitously anti-American concert programme. Phillips made no new friends by refusing to sing 'The Star Spangled Banner', explaining to anyone who would listen

41 Ibid., 1:221; 2:209, 277-9.

42 Ibid., 1:172; see also Musical World (20 September 1884): 596. 
that the tune was not of American origin. ${ }^{43}$ Insisting upon Dibdin's veneration as a national bard made him difficult to repackage as a cultural export.

\section{DIBDIN'S GHOST IN THE AGE OF IRONCLADS}

In 1864, reflecting on the collection of first-hand testimonials that he had assembled two decades earlier, Phillips offered this surprising summation:

These letters... are at once an evidence how universally Dibdin was admired, and how, both as a melodist and poet, we may consider him such as we may never meet with again; for, the mode of naval warfare being so altered, there is not the same incentive to such themes; and I much fear that the national character may also lose much of its freshness under existing circumstances. An English sailor does not like skulking behind iron plates, or delight in the sinking of an enemy's ship, without daring to show his face. His delight is to look steadily at his foe, to rush at him, conquer him, and tug him bound and humbled into harbour. The new mode of fighting will never create another Dibdin. ${ }^{44}$

Just how Dibdin, who never fought a battle in his life and hardly ever went to sea, was himself the expression of 'a mode of fighting' is not explained. ${ }^{45}$

It is not, perhaps, surprising that a professional singer would think of songs as especially important expressions of the spirit of an age. But these sentiments about Dibdin were not unique to Phillips. In 1875, Punch ran a satirical poem, 'You must not speak to the man at the wheel', deriding a botched Admiralty investigation into an accident involving ironclad warships. The title referred to a standard warning message posted aboard steam-powered vessels and echoed common anxieties of the period about self-propelled devices and high-speed collisions, such as with out-ofcontrol locomotives. ${ }^{46}$ The poem is subtitled 'A new Sea Song, by the Ghost of Charles Dibdin' and plays up the dissonance between Britain's nautical past and present with lines such as "Twas "Shiver my timbers!" once, my mates; / This time it came to "Shiver my plates!" One stanza evokes Dibdin's lyrics explicitly:

For the sweet little Cherub that sits up aloft-

If Cherubs e'er swear, he must do it oft-

Poor JACK should pray for a smart engineer,

And a kettle of steam that will swim and steer.

Once a sink, or a smash, or a sudden capsize

Would have made old salts make free with their eyes;

But now civility outdoes zeal,

And we never swear at the Man at the Wheel. ${ }^{47}$

\footnotetext{
43 Phillips, 2:110-15. 44 Ibid., 2:16-17.

45 For anxieties about technological change and its impact on national character, see also Land, War, 131-58.

46 Ian Carter, Railways and Culture in Britain: The Epitome of Modernity (Manchester: Manchester University Press, 2001).

47 Punch (11 December 1875): 240.
} 
Like Phillips, Punch emphasizes the impersonal, technocratic nature of the contemporary ironclad navy. As Kennerley has demonstrated in Chapter Five of this volume, Dibdin contested the terrain of 'manly independence'; would this cold, metallic environment make expressions of that ideal all but impossible in practice? Ships were no longer even ships, but 'kettles of steam', leaving sailors no longer in charge, but at the mercy of 'a smart engineer'. Who would weep at the loss of such a mechanical monstrosity?

By contrast, the 1892 sale of the historic HMS Foudroyant for scrap elicited an outpouring of anger, bewilderment, and regret. In January, the coal magnate Geoffrey Wheatley Cobb (1859-1932) made a public appeal to save the Foudroyant. ${ }^{48}$ He wrote in The Times, 'A sailing three-decker, is, however as much a relic of a past age as a mediaeval castle, and the Society for the Protection of Ancient Buildings might do worse than extend its operations to such ships ... and endeavour to preserve them from wanton destruction. ${ }^{39}$ In the previous year, an elaborate and expensive model of HMS Victory had been displayed at the Royal Naval Exhibition in Chelsea. Cobb stressed that the Foudroyant was the real thing, equating the preservation of authentic naval heritage with the preservation of authentic manhood:

It is safe to affirm that 20 years hence not one of the ships built within the first decade of this century will be in existence unless steps are taken for their preservation... It is difficult to believe that there is a single Englishman or boy to whom it would not appeal irresistibly; there is surely no one to whom it would not be at least as attractive as a Watkin tower or a papier-mâche Victory with a group of wax dolls in its cockpit.

Mere 'wax dolls' could never substitute for real sailors, real boys, real men. Cobb argues that an open-air exhibit represented a viable alternative to selling the old ships for scrap: '[I]f half a dozen of them were brought together in Portsmouth Harbour, they would form a naval museum of such interest as to be, in a measure at least, self-supporting.'

Cobb continued to lead the charge on this issue from January to September, with added urgency as the Foudroyant was now docked in a Baltic port, where its German buyer would soon dismantle it and sell the wood for kindling. He offered to part with it, however, for $£ 5,500 .{ }^{50}$ The imminent prospect of losing the ship for good prompted a wave of concern. Arthur Conan Doyle wrote a poem about it, and throughout September, newspapers across England, Wales, and Scotland ran news updates, opinion pieces, and letters to the editor about the fate of the old wooden warship on an almost daily basis.

In Dundee, the Evening Telegraph ran a summary of the plans to save the Foudroyant under the evocative headline 'A Lesson in Patriotism'. ${ }^{51}$ Nelson's flagship at Trafalgar, the Victory, had already been preserved as a piece of naval

48 Andrew Lambert, Trincomalee: The Last of Nelson's Frigates (Annapolis, MD: Naval Institute, 2002), 109.

49 The Times (7 January 1892).

50 Geoffrey Wheatley Cobb, 'The End of One of Nelson's Flagships', The Times (2 September 1892).

51 Evening Telegraph (Dundee, 12 September 1892). 
heritage, but articles noted that the Foudroyant, too, had an intimate connection with the admiral. The Hampshire Telegraph and Sussex Chronicle observed that it was 'except the Victory, the only ship now remaining of these in which Lord Nelson served and which bore his flag', 52 while the Nottingham Evening Post elaborated on the Foudroyant's relationship to some of Britain's finest naval victories: 'Nelson selected her as his flagship, but she was not ready in time or she would have borne his flag at the Battle of the Nile. Subsequently, however, she was present in Aboukir Bay. 53 The Illustrated London News ran a photograph of the Foudroyant and remarked that the story of its sale for scrap 'reads like a malicious fantasy of a Parisian journalist who wants to have a fling at "the nation of shopkeepers"'. The wooden warship should have been honoured as a survivor of 'the historic single combats which belong to that Homeric period of our naval annals' ${ }^{54}$

References to Nelson were only to be expected, but the other name repeatedly mentioned in coverage of the Foudroyant was Dibdin's. The Penny Illustrated Paper wrote:

In the old sea-songs that were popular among our patriotic ancestors, such as Dibdin's and others, the most endearing expressions of affection were applied to notable fighting vessels which had helped to win for our country its trophies of naval renown. Why is a ship called 'she,' if not because the sailor regards it as a living personality, not less dear and venerable than his own grandmother, a floating deputy-Brittania [sic], an artificial goddess of war and the waves? That feeling, however, seems to have died out in this generation; at least, it is not now shared by the civilian officials at Whitehall. ${ }^{55}$

The Illustrated London News, without mentioning Dibdin by name, managed to evoke Nelson, manly Jack Tars, and the characteristic lyrics of the Ocean Bard together in a single paragraph:

What his men thought of [Nelson] is expressed in the rude but eloquent homage of the letter some of them wrote when he was quitting the ship... What would these men say if they could come back to earth to find the vessel which was the flag-ship of their hero sold to foreigners for firewood? Their language would not be decorous, but it would express a thoroughly English sentiment with equal truth and vigour. ${ }^{56}$

Much as 'You must not speak to the man at the wheel' had mocked an age of cowardly 'civility' and mismanagement by assuming the voice of Dibdin's ghost to reproach the Admiralty, so the Illustrated London News revived the Foudroyant's long-dead crew to upbraid the ship-sellers, using — of course- the 'rude but eloquent' phrasing associated with Dibdin's songs. Through such juxtapositions, the sale of the Foudroyant became a betrayal of Nelson, Nelson's crews, and Dibdin.

52 Hampshire Telegraph, and Sussex Chronicle (3 September 1892).

53 'Metropolitan Notes', Nottingham Evening Post (3 September 1892).

54 Illustrated London News (17 September 1892).

55 'One of Nelson's Old Flag-ships', Penny Illustrated Paper and Illustrated Times (17 September 1892). For another Dibdin reference, see 'A Famous Battleship', Newcastle Weekly Courant (19 November 1892).

56 Illustrated London News (17 September 1892). 
The longest evocation of Dibdin during the controversy was a poem 'The Fighting Foudroyant'. The title recalls Turner's painting The Fighting Temeraire, yet it is Dibdin, not Turner, who is named in almost every stanza:

'Mayhap you have heard, that as dear as their lives,

All true-hearted Tars love their ships and their wives.'

So Dibdin declared, and he spoke for the Tar;

He knew Jack so well, both in peace and in war!

But hang it! times change, and 'tis sad to relate,

The old Dibdinish morals seem quite out of date;

Stick close to your ship, lads, like pitch till you die?-

That sounds nonsense to-day, I'll tell ye for why. ${ }^{57}$

By December, the Foudroyant would be repurchased and back in British waters, preserving the 'old Dibdinish morals' in its timbers for a new generation. ${ }^{58}$ The buyer, Cobb, did not turn it into a museum ship like the Victory after all. Instead, he set it up as a training vessel where destitute boys could be set on a path to a naval career. When a gale off Blackpool in 1897-just five years later-wrecked the Foudroyant beyond hope of repair, Cobb purchased two other Nelson-era wooden warships, the Trincomalee and the Implacable, for the same purpose. Out of stubbornness, perhaps, he renamed the first of these the Foudroyant. This educational work carried on for decades: after Cobb's death and up to the eve of the Second World War, several generations of Sea Scouts and Sea Rangers would train aboard these ships. ${ }^{59}$ While some claimed that the boys would pick up 'nautical comradeship and discipline', lessons of that sort could easily have been imparted aboard a safe, modern vessel rather than a museum piece. ${ }^{60}$ It is hard to see how seamanship learned on these creaking relics could have prepared boys for naval combat in the fast-paced new century. HMS Dreadnought, the first modern battleship, rendered the 'kettles' of the ironclad era obsolete in 1906, and the early submarines promised to do the same to the Dreadnought before long. ${ }^{61}$

To be sure, the enduring appeal of the 'tall ship' has complex roots. Yet if the belief persisted that 'an English sailor does not like skulking behind iron plates', and wooden warships remained a talisman of British manhood, Dibdin's songs deserve at least a share of the credit. ${ }^{62}$ As the Foudroyant affair illustrates, it was difficult

57 Hampshire Advertiser (24 September 1892). The poem originally appeared in Punch.

58 'The last voyage of the Foudroyant', Pall Mall Gazette (2 December 1892).

59 Lambert, Trincomalee, 109-16; Hugh Murphy and Derek J. Oddy, The Mirror of the Seas: A Centenary History of the Society for Nautical Research (London: Society for Nautical Research, 2010), 32, 76-8; Martin Bellamy, 'Financing the Preservation of Historic Ships', Mariner's Mirror 97 (2011): $344-65$.

60 Lambert, Trincomalee, 114.

61 Duncan Redford, The Submarine: A Cultural History from the Great War to Nuclear Combat (London: I. B. Tauris, 2010).

62 Kevin Littlewood and Beverley Butler, Of Ships and Stars: Maritime Heritage and the Founding of the National Maritime Museum Greenwich (London: Athlone, 1998), 1-50; Brad Beaven, 'From Jolly Sailor to Proletarian Jack: The Remaking of Sailortown and the Merchant Seafarer in Victorian London', in Brad Beaven et al. (eds), Port Cities and Urban Cultures (Basingstoke: Palgrave Macmillan, 2015). 
fully to disentangle nostalgia for Dibdin, nostalgia for Nelson's veterans themselves, and nostalgia for the ships of the Trafalgar era. It was this Dibdin, elevated to the status of sailor-laureate and 'bard', that would survive into the twentieth century. 'Tom Bowling' formed one movement of Henry Wood's 'Fantasia on British Sea Songs', composed for the centenary of Trafalgar in 1905. An instant favourite with audiences, the 'Sea Songs' would be played at the Last Night of the Proms fairly consistently for one hundred years thereafter; 'Tom Bowling' is performed to this day. Wood remarked on what the boisterous audience participation characteristic of the Last Night meant to him: 'When I look down on that sea of faces before me and conduct my great, amateur, untrained choir, I know that I am British, I know that I am in my native London, and I know that in them the spirit of Horatio Nelson still lives and will never die.' 63

63 David Cannadine, 'The "Last Night of the Proms" in Historical Perspective', Historical Research 81 (2008): 315-49, 326. 
Comp. by: Kalaimathy Stage : Revises 1 ChapterID: 0003304487 Date:7/10/17

OUP UNCORRECTED PROOF - REVISES, 7/10/2017, SPi 


\title{
Afterword \\ Dibdin's Miscellany
}

\author{
Mark Philp
}

This volume demonstrates the validity of the editors' opening remarks— that to study Dibdin's work one needs an eclecticism and range of expertise that pose a challenge to the multiple and divided worlds of academic disciplinary study in the twenty-first century. That challenge indicates Dibdin's importance as a window onto a cultural world that changed dramatically in the last years of his life and subsequently. Andrew Robinson's study of the polymath Thomas Young (1773-1829) was called 'The last man who knew everything'. ${ }^{1}$ This involves a degree of hyperbole-Young did so largely in relation to what we might call the sciences-but it captures the sense that the breadth of what it was once possible to know narrowed dramatically in the opening decades of the nineteenth century. The elder Dibdin might be regarded as an arts equivalent. Covering an extraordinary range of music, acting, circuses, equestrianism, educational ventures, and theatrical production, while also publishing prints, novels, memoirs, histories, tours, and periodicals, Dibdin traversed a variety of what are now highly specialized spheres of activity and study. Moreover, his way of knowing these worlds was not ours. Indeed, rather than thinking of him as a polymath of the arts with an intellectual grasp of its various dimensions, we might best see him as experiencing these dimensions as part of an integrated world within which he was able to exercise his genuine talent for eliciting responses from a wide range of the public. In many respects he had a fine entrepreneurial and intuitive practical nous as to what would garner an audience, and what would keep them coming back for more, across a number of different endeavours. Even as he did so, however, this public culture was beginning to divide into distinct aesthetic spheres, with tastes becoming more refined and exclusive, more plural, but equally more sequestered.

In this afterword, informed by the chapters collected here, I want to reflect briefly on Dibdin's success, and its relationship to its political context, especially during the Revolutionary and Napoleonic Wars. Until recently, scholarship on the eighteenth century offered a narrative of the gradual emergence of polite society, and a correlative polite world of the literature and the arts. The work of Simon Dickie and Vic Gatrell, among others, has encouraged us to recognize that, while politeness may well have come to characterize some spheres of life, some dimensions of individual lives, and some areas of public and private culture, there were

1 Andrew Robinson, The Last Man Who Knew Everything (London: Oneworld, 2006). 
equally strong traditions of the bawdy, scatological, and scurrilous. ${ }^{2}$ The result of this revisionism is an increasing sense of there being a more plural, contested, and conflicted cultural and social world at the end of the eighteenth century than scholars might once have found-or that certain polite, late-Georgian novelists might have tempted the modern reader with. Playing to the crowd in such a diverse and conflictual context was doubtless a daunting if also exhilarating prospect: in contrast, more specialized, refined, and rule-governed aesthetic performances might be less exposing, more technically accomplished, played to a more hushed and reverential audience - and less fun. The attempts by the coming generation after 1810 to take Dibdin up, but to aestheticize and purge his songs (see Cox Jensen's and Land's chapters in this volume) are a striking instance of how rapidly the cultural world was changing in his final years. As distant inheritors of those aesthetic and disciplinary changes we find it difficult to make sense of his miscellaneous life and its miscellaneous context-and perhaps above all we find it difficult not to try to impose order, rationality, principles, or aesthetic sense across the range of Dibdin's various 'performances', while simultaneously lacking the versatility to appreciate the full range of his achievements.

We face a further difficulty in gauging his contemporary significance and subsequent influence, especially in the troubled decades after 1789. And there is the further challenge of estimating how far the events of that period might have played an important part in the development of the changes in public culture that marked the beginning of the nineteenth century. Associated with these difficulties is the fact that our specialisms and our 'modernity' do not help us to imagine the impact of Dibdin's performances on a world so very different from our own-both the immediate impact in terms of entertainment, laughter, and the eliciting of a range of emotions, and the longer-term effect of these on the ways in which people experienced their world and thought about the choices before them-perhaps especially in terms of the war with France and the crisis of legitimacy for William Pitt the Younger's government.

One feature of eighteenth-century life that E. P. Thompson liked to emphasize was its rambunctiousness - its sheer absence of politeness and its cross-class tensions and insolences: '[T]hey enjoyed liberties of pushing about the streets and jostling, gaping and huzzaing, pulling down the houses of obnoxious bakers or Dissenters, and a generally riotous and unpoliced disposition which astonished foreign visitors, and which almost misled them themselves into believing that they were free.' ${ }^{3}$ A component of that public culture was its very openness - that, if not everyone, then at least a fair slice of all and sundry could turn up at the theatre, could abuse the actors, sing the songs, laugh and cry together, and jostle their betters in the crowd. And outside the theatre many of its songs were accessible to all through slips and ballad sheets or from the singing of ballad sellers in the streets. Linking to that audience-indeed, winning over that audience, keeping it engaged,

\footnotetext{
2 Simon Dickie, Cruelty and Laughter: Forgotten Comic Literature and the Unsentimental Eighteenth Century (Chicago: Chicago University Press, 2011); Gatrell, City of Laughter, Kate Davison, 'Occasional Politeness and Gentleman's Laughter in $18^{\text {th }}$ C England', Historical Journal 57 (2014): 921-45.

3 E. P. Thompson, Customs in Common (Harmondsworth: Penguin, 1993), 95.
} 
rather than suffering its hostility — might require a range of techniques and resources: spectacle, pathos, tragedy, laughter, or drawing upon references and imagery that could elicit and capture the imagination. Reaching into that world is difficult for us: our relationship to music is different simply by virtue of its variety and accessibility in the modern world; and our taste in entertainment is dramatically different, in part because of the spectrum available and the technological innovations available to deliver it, but also in part because of the implicit connections we make, relatively unconsciously, between aesthetic distinctions and social registers. Although late-eighteenth-century London had considerable variation in forms of public performance, it was a dramatically more constrained, but also a potentially less divided and more open palette with which to innovate and entertain than we face today. Yet Dibdin demonstrated his capacity to do precisely that over and over again, and he did it in a way that invited a broad section of the population into his audiences.

This volume contributes to our understanding of exactly how Dibdin achieved that-for example, by writing material that was closely linked to particular performers, by care and investment in the staging of material, by working on connections with theatre managers, and eventually by taking the whole operation of the theatre into his own hands. But the more puzzling aspects to the modern reader and scholar are issues such as: What made people laugh, and what sort of laughter was it? Why did certain songs catch on, and others not? What sorts of spectacle might bring people back for more, or was spectacle always a short-lived phenomenon, resulting in either satiety or the search for something still more spectacular? What material worked with which kind of audience, and exactly what sort of audiences did Dibdin's work attract? For example, the philosopher, novelist, and aspiring dramatist William Godwin, despite being a regular theatregoer, seems to have caught only an afterpiece of Dibdin's — his 'Divertissement' - following a performance of Venice Preserved in November 1790, and a performance of The Waterman in $1810 .{ }^{4}$ Despite Thomas Holcroft's musical and theatrical interests he does not seem to have met Dibdin, although he met Dibdin's son Thomas, probably on several occasions. He also indicated the latter's acknowledgement of the virtues of Charles Dibdin the Younger; and he recorded his disapproval of their father for his 'reprehensible' conduct towards his illegitimate sons. He was clearly aware of Thomas Dibdin's work, but made no reference to that of his father besides describing him-perhaps over-restrictively—as a 'musical composer'. ${ }^{5}$ Joseph Farington reports at second hand Dibdin senior's singing at the anniversary dinner for the Royal Academy, where his informants 'were well pleased with humorous songs sung by Dibdin' ( 5 June 1807), but does not record that he himself attended any performances. ${ }^{6}$ So there is an issue about who his audience was and how far he

\footnotetext{
4 Victoria Myers, David O'Shaughnessy, and Mark Philp (eds), The Diary of William Godwin (Oxford: Oxford Digital Library, 2010), http://godwindiary.bodleian.ox.ac.uk.

5 Thomas Holcroft, Memoirs of the Late Thomas Holcroft, 3 vols (London, 1816), 3:133.

6 The Diary of Joseph Farington, Index Volume, ed. Kathryn Cave (New Haven: Yale University Press, 1998), 3059.
} 
tailored his adaptations for particular audiences (such as the RA), as against his more popular productions. It is also worth emphasizing that some of his most successful periods were when touring the country at large to audiences that were potentially rather different from those encountered in London. Above all, what enabled him to connect with these diverse audiences, and to what effect?

Dibdin had his own views as to the reasons for his success: writing with respect to his 1792-3 entertainment Castles in the Air, he claimed:

I must confess that if I had gratified my inclination, and gone for fame alone, I should have written my performances in a style of elevation, and given them a classical turn; but I knew that trifles, mere nothings, were best calculated to succeed with the public. Of what use would it have been to lecture my audience when it was my business to make them laugh, which nothing can do, or ever did, but broad humour?...My business has been as much as possible to give an opposite effect to the song, as they succeed each other... I therefore leave the subject of the song gradually, get into some extraneous matter, and then bring the audience into that state of temper that best inclines them to relish the song which is to follow[.] $]^{7}$

This alternation - and transitioning - between comic and sentimental was a crucial component of many of his works. So too, was the recurrent theme of the unthinking world and its cruelty or indifference towards those who are marked by goodness and virtue. In 'Tom Tackle', also from Castles in the Air, Tom is over and over again despised for his poverty, brought on by his kindness and benevolence, until he is finally set on his feet with a pension that gives him 'just enough to be gen'rous- too much to be poor'. ${ }^{8}$ Dibdin's final song in performances of Castles, 'The Trial', reviewed the likely indictment that his critics would level at him, and then ran through the characters represented in the songs in order to defend himself:

\footnotetext{
The indictment runs thus-If it plainly appears,

That said Dibdin, of critics despising all fears

Hath corrupted your hearts, while he tickles your ears,

He stands guilty-if not, he's acquitted.

But to clear me, I trust, of all dulness prepense,

I'll examine each witness by way of defence:

In his bulls shall my Irishman blunder good sense,

Nor be even my ploughman omitted.

Tom Tackle humanity's duty shall teach;

My Soldier your hearts through compassion shall reach;

My Parson shall pray, and my Gipsy beseech,

That I may be fairly acquitted. ${ }^{9}$
}

The contrasting and alternating emotions that Dibdin generates are here seen to build a case — and a judgement in the singer's favour-to acquit him of corrupting the hearts of his audience, by having warmed them and opened them to his characters, and by having gratified their own sense of good judgement-with a hefty degree of indulgence to the clumsy but well-meaning people he has conjured up.

$$
7 \text { Life, 3:273-5. } \quad{ }^{8} \text { Hogarth, 1:139. } \quad 9 \text { Ibid., 1:141. }
$$


As has been argued in this volume, this is certainly not tub-thumping loyalism, but neither is it radicalism. It is entertainment that achieves its effect in part by generating a degree of moral complaisance: a sense that there is a natural order to the world, in which true British character plays a large role, but it is one that the entertainment serves to elicit and confirm, through playing with the laughter and sentimentalism of its audience. Perhaps it is not surprising that the intellectuals whose diaries we have show so few signs of indulging in Dibdin's entertainment - and not surprising that when he turned up at the Royal Academy in 1807, Farington's reference was to comic songs, not to the more sentimental form. But his real métier was a slightly different audience, of largely ordinary people, whom he played with great skill.

In many ways one of the most difficult aspects to understand in this period, in relation to public culture and its complexities, is the interaction between entertainment and politics that much of Dibdin's work epitomizes. This is especially true of his sailor songs, but it is certainly not restricted to these: as Felicity Nussbaum shows in Chapter Two of this volume, there are dimensions of his blackface acting and representation of race that raise similar issues. Indeed, there is a danger of imposing upon Dibdin's world a conception of politics, based on lyrics, recitatives, and narratives, which misses something central to that world. When the shoemaker and reformer Thomas Hardy wrote to his cousin that he relished a dish of politics, a not uncommon expression, we should take the metaphor of consumption seriously. It was an imbibing of news and events and a discussing of their significance. For most people politics meant just that, or else meant more specifically the high politics of parliament and international affairs, over which they had no control and upon which they conceived themselves as having little influence: a set of background events, or public theatre, rather than a sphere of agency. Hardy's London Corresponding Society began to change that conception for some of its members, but for the audiences streaming to Dibdin's entertainments, comments on and references to public affairs were likely to be attended by a frisson of recognition, rather than experienced as an invitation, let alone an incitement, to political activity. We might see something similar taking place in Dibdin's contributions to issues of race and equality, the contradictions of which Nussbaum explores. Take for example the song, written for The Islanders in 1780-

Dear Yanko say, and true he say,

All mankind, one and t'other,

Negro, mulatto, and malay,

Through all the world be broder.

— the second verse of which begins:

What harm dere in a shape or make?

What harm in ugly feature?

Whatever colour, form, he take,

The heart make human creature. ${ }^{10}$

10 Life, 2:74-5. 
The caricature of speech, doubtless exaggerated further on stage, nonetheless sits alongside an ostensible message of brotherhood-albeit there is no mention in the song of whites, and the chorus of 'Negro, mulatto, and malay' might be interpreted as a sequestering of subspecies, rather than an appeal to the wider brotherhood of man. But rather than emphasize the words, we might equally emphasize the sentiment that the song, with words and music combined, might elicit: a ballad with a melodic chorus that in itself encourages a sympathy and sentimental union with the singer that need not be undercut by the patronizing representation of the language. We cannot be sure that this is the way to read (or hear) it, or that it was ever experienced in this way, but the example indicates the difficulty of focusing wholly on the lyric of the song to capture its impact on the audience. Moreover, pathos and sentimentality are not inevitably an invitation or spur to action in one's private life, let alone on the local political stage, which for most people would be the limit of their self-conception as a political agent. Only in the development of mass petitioning at the end of the century, with the innovative move of a sugar boycott inspired by William Fox in 1791, and with the establishment of corresponding societies and associations for the dissemination of information, did forms of practical political action offer themselves to those so moved; and certainly Dibdin does not himself enjoin such action.

Similar difficulties attend our reading of loyalism into the sailor songs. In the Professional Life, Dibdin's expression of outrage at being cast as a government pawn paid $£ 400$ a year to open against Thelwall's lectures in Beaufort Buildings in the Strand was a little overdone, as was his claim that on the basis of these rumours he was rejected by 'a large body of the public'. Nonetheless, we should acknowledge his insistence that he was not seeking to command obedience, but 'mildly, recommending acquiescence', and was convinced that in doing so he was conveying 'a proud compliment to the mind of every honest man and honourable subject'. ${ }^{11}$

Perhaps the subtlety of Dibdin's politics was that it was not really 'politics' as we think of it: not a spur to action so much as an emotional bridge to one's fellow men and women that enabled people to find the 'better' part of their natures as English men and women, and drew it out for them to be reflected to them, amused by, and warmed by. This is not unlike some of the bawdier prints, squibs, and lampoons of public culture, such as those discussed by Harriet Guest in relation to Margate: nothing too refined, something for men and women with heart and humour, and for people who can see that human nature has a rude type of health and who reflect on it with satisfaction. Not much of the sponsored loyalism in the $1790 \mathrm{~s}$ was of this form-it was tub-thumping, imperative, enlisting, and dogged, and it found unorthodoxy in multiple places. That culture was dramatically less tolerant and substantially less confirmatory than that which might be experienced at a Dibdin entertainment, yet its reach was very considerable, creating an atmosphere in which innovation was suspect and in which cultural forms might need to become highly specialized to avoid accusations of corrupt populism. This loyalist culture of 
suspicion mistrusted any easy mixing of class and status, and it was compounded by an emerging moralism and evangelism that sought to discipline the habits of the lower orders, and turned its attention to the more doubtful pastimes of the middling sort. In this culture, even Dibdin could become suspect.

That this public culture underwent a set of rather straitening vicissitudes in the first half of the nineteenth century-becoming more specialist and more divided, with popular sports and pastimes increasingly policed, and the lustier aspects of life relegated to the dens and alleyways by a sense of both propriety and improvement_-did not eliminate Dibdin's appeal. But increasingly it 'edited' him, and his market narrowed accordingly. Indeed, Dibdin himself recognized the extent to which the Wars had filled the theatres of the revolutionary period, a subject discussed further by Valladares in Chapter Nine-in part because of people being on the move, but also because of people's need for distraction and entertainment, and perhaps their need for confirmation of their membership of a collective, and thereby their search for collective laughter to provide relief from cares. ${ }^{12}$ If that is right, then much of Dibdin's loyalism was a case of giving people what they wanted: less propaganda, more emotional release, legitimized laughter, and distraction, and for many the fulfilment of a desire for confirmation in and of an order that they found some satisfaction in endorsing and in seeing themselves as embodied and contained within. Contained within, that is, not as identical subjects, but as members of a wide cast of characters, a miscellaneous bunch brought together and united, if only for a while, in a set of common (both basic and shared) emotions and reactions. Moreover, while a general tone of loyalism remained, it could also be suspect. The political polarization of the 1790s and early 1800s can be seen as placing considerable strain on this miscellany of types, with its robust humour, playful satire, and tolerant ironies. And that strain might have contributed to the increasing fragmentation of popular culture, and an increasing aestheticization and sequestering of the arts, in ways that increasingly de-popularized and thereby partly depoliticized much literary, theatrical, and artistic culture.

Dibdin's one-man band, then, played to a potential audience for a united Britain, yet his legacy found a more restricted set of spaces and played to more targeted and delimited audiences. For all his long legacy, the nineteenth century ironed out a good deal of the heart and soul, the pathos, robust mirthfulness, and bonhomie of Dibdin's theatricals and performances. Grasping his earlier appeal helps us also to see something of a rather different world—one that the years after 1815 sought to set firmly in the past and against which there developed a widening range of specialist performances for suitably appreciative, attentive, and disciplined audiences. Recovering Dibdin's rich, miscellaneous world should help us to recognize how dramatically popular culture began to change in the course of the revolutionary era.

12 On forms of laughter and eighteenth-century understandings of it, see Mark Knights and Adam Morton (eds), Laughter and Satire in the Early Modern Period (London: Boydell \& Brewer, 2017), Chapter One. 
Comp. by: Kalaimathy Stage : Revises 1 ChapterID: 0003304491 Date:8/10/17
Time:08:34:11

OUP UNCORRECTED PROOF - REVISES, 8/10/2017, SPi 


\section{Bibliography}

Throughout the bibliography, works by a single author are listed chronologically.

\section{SELECTED WORKS BY CHARLES DIBDIN}

N.B. For a full bibliography of the works of Charles Dibdin the Elder, see Dibdin, Edward Rimbault, A Charles Dibdin Bibliography (Liverpool: Privately Printed, 1937).

A Collection of English Songs and Cantatas... Opera Primo (London, 1761).

The Shepherd's Artifice, A Dramatic Pastoral (London, 1765).

The Songs in the Comic Opera of the Captive (London, 1769).

The Waterman. A Comic Opera of Two Acts (London, 1774).

The Comic Mirror, or, The World as it Wags (London, 1775).

The Seraglio: A Comic Opera, in Two Acts (London, 1776).

The Graces, an Intermezzo in One Act. As it is Performed at the Royal Circus, in St. George's Fields (London, 1782).

The Cestus: a Serenata as Performed at the Royal Circus (London, [1783]).

The Royal Circus Epitomized (London, 1784).

The Magic of Orosmanes; Or, Harlequin Slave and Sultan: A Pantomime, Drawn from the Arabian Legends (London, 1785).

The Devil, 2 vols (London, 1786-7).

The Musical Tour of Mr Dibdin; in which—previous to his embarkation for India-he finished his career as a public character (Sheffield, 1788).

The By-stander; or, Universal Weekly Expositor. By a Literary Association (London, 1789-90).

A Letter on Musical Education, by Mr Dibdin (London, 1791).

A Collection of Songs, Selected from the Works of Mr Dibdin, 2 vols (London, 1792)

Hannah Hewit; or, The Female Crusoe, 3 vols (London, 1792).

The Younger Brother: A Novel, 3 vols (London, [1793]).

A Complete History of the English Stage, 5 vols (London, 1797-1800).

Songs, erc. In New Years Gifts. A New Entertainment of Sans Souci. Written, Composed, Spoken, Sung, and Accompanied By Mr Dibdin (London, 1802?).

Observations on a Tour through almost the whole of England, and a considerable part of Scotland, in a series of letters, addressed to a large number of intelligent and respectable friends, 2 vols (London, 1802).

The Professional Life of Mr Dibdin, written by himself, together with the words of six hundred songs, 4 vols (London, 1803).

British War Songs (London, 1803).

The Harmonic Preceptor (London, 1804).

The Musical Mentor, or St. Cecilia at School (London, 1805).

The English Pythagoras, or, Every Man His Own Music Master (London, 1807).

Henry Hooka. A Novel, 3 vols (London, 1807).

The Public Undeceived, written by Mr Dibdin; and containing a statement of all the material facts relative to his pension (London, [1807]).

The Professional Life of Mr Dibdin [including the engraving and plates intended for the 1803 edition] (London, 1809).

Music Epitomized: A School Book (London, c.1810). 
Six Lessons for the Harpsichord, or Piano Forte (London, n.d.).

The Overture \& Favorite Songs in the Blackamoor: A New Comic Opera (London, n.d.).

\section{SELECTED COLLABORATIONS OF CHARLES DIBDIN}

With Bate Dudley, Henry, The Black-a-Moor Wash'd White: A Comic Opera (1776), in Larpent MS 400, Huntington Library.

With Bickerstaff, Isaac, Lionel and Clarissa: A Comic Opera (London, 1768).

With Bickerstaff, Isaac, The Padlock: A Comic Opera (London, 1768).

With Bickerstaff, Isaac, The Captive. A Comic Opera (London, 1769).

With Bickerstaff, Isaac, The Sultan; or, a Peep into the Seraglio. A Farce in Two Acts (London, 1781).

With Garrick, David, Songs, Chorusses, \&o. which are introduced in the New Entertainment of the Jubilee, at the Theatre Royal, in Drury Lane (London, 1769).

With Waldron, Francis Godolphin, How Do You Do?, nos.1-8 (London, 1796).

\section{COMPILATIONS OF CHARLES DIBDIN}

Anon. The Songs of Charles Dibdin, 2 vols (London, 1839).

Anon. The Selected Songs of Charles Dibdin (London, 1845).

Barrett, William Alexander (ed.), Twenty-One Songs Composed by Charles Dibdin. 1745-1814. (London and New York, [1890]).

Dibdin, Edward Rimbault, A Charles Dibdin Bibliography (Liverpool: Privately Printed, 1937).

Dibdin, Thomas, Songs, Naval and National, of the late Charles Dibdin, with a Memoir and Addenda (London, 1841).

Dibdin, Thomas, Songs of the Late Charles Dibdin: With a Memoir (2nd edn, London, 1841).

Dibdin, Thomas, Songs of the Late Charles Dibdin; with a Memoir (3rd edn, London, 1852).

Hogarth, George, The Songs of Charles Dibdin, chronologically arranged, with notes, historical, biographical, and critical, 2 vols (London, 1842, 1848).

Kitchiner, William, The Sea Songs of Charles Dibdin, with a memoir of his life and writings by William Kitchiner, M.D. (London, 1823).

\section{SELECTED WORKS BY CHARLES ISAAC MUNGO AND THOMAS JOHN DIBDIN}

Dibdin, Charles Isaac Mungo, Poetical Attempts: By A Young Man (London, 1792).

Dibdin, Charles Isaac Mungo, Songs, \&o with a Description of the Scenery in the New AquaDrama called 'The Corsair' (London, 1814).

Dibdin, Charles Isaac Mungo, Songs, \&o in the Pantomime called 'Harlequin Brilliant; or, The Clown's Capers' (London, 1815).

Dibdin, Charles Isaac Mungo, Songs, and other Vocal Compositions in the Pantomime called 'Mermaid; or, Harlequin Pearl Diver!' (London, 1815).

Dibdin, Charles Isaac Mungo, Young Arthur; or, The Child of Mystery: A Metrical Romance (London, 1819).

Dibdin, Charles Isaac Mungo, A History of the London Theatres (London, 1826).

Dibdin, Charles Isaac Mungo, Memoirs of Charles Dibdin the Younger, ed. George Speaight (1830, pub. London: Society for Theatre Research, 1956).

Dibdin, Charles Isaac Mungo, The Physiological Mentor; or, Lessons from Nature (London, 1833). 


\section{Bibliography}

Dibdin, Thomas John [as Thomas Merchant], Comic Songs (London, 1794).

Dibdin, Thomas John [as Thomas Merchant], The Mad Guardian: or, Sunshine after Rain. A farce (1793, pub. Huddersfield, 1795).

Dibdin, Thomas John, Songs, Chorusses, \& $c$. in the New Pantomime of Harlequin's Tour; or, The Dominion of Fancy. As Performed at the Theatre-Royal, Covent Garden (London, 1800).

Dibdin, Thomas John, Five Miles Off; or, The Finger Post (London, 1806).

Dibdin, Thomas John, Bonifacio and Bridgetina; or, The Knight of the Hermitage; or, The Windmill Turrett; or, The Spectre of the North-East Gallery (London: J. Barker, 1808).

Dibdin, Thomas John, A Metrical History of England (London, 1813).

Dibdin, Thomas John, Harlequin Hoax, or, A Pantomime Proposed (London, 1814).

Dibdin, Thomas John (ed.), The London Theatre, 6 vols (London, 1815).

Dibdin, Thomas John, Dibdin's London Theatre, 26 vols (London, 1815-18).

Dibdin, Thomas John, Morning, Noon and Night; or, The Romance of a Day (London, 1822).

Dibdin, Thomas John, The Cabinet (New edn, London, 1829).

Dibdin, Thomas John, Tom Dibdin's Penny Trumpet, 4 nos (Oct-Nov 1832).

Dibdin, Thomas John, Last Lays of the Last of the Three Dibdins (London, 1833).

Dibdin, Thomas John, The Reminiscences of Thomas Dibdin, 2 vols (London, 1837).

\section{ARCHIVAL SOURCES/COLLECTIONS}

British Library, Add. MS 27825: Francis Place, 'Collections relating to Manners and Morals'.

British Library, Add. MSS 30960-7: Charles Dibdin, 'Fragments ...'.

The Garrick Club, London (uncatalogued), 'Sadler's Wells Scene Book'.

Hampshire Record Office, 28A11/A3, A7-A8: Jane Austen Songbooks.

Huntington Library, California, John Larpent Plays, 1814 MS.LA1824, Manuscript of Thomas Dibdin, Harlequin Hoax; or, A Pantomime Proposed.

Royal College of Music, Taylor Collection 2143, Series 6 of 7 of Edward Taylor's lectures on English Dramatic Music, Lecture 3: Edward Taylor, 'Charles Dibdin'.

University of Harvard, Houghton Library Theater Collection, MS Thr 198: fragments by and relating to Charles Dibdin.

Victoria and Albert Museum, Theatre Collection: 'Astley's Amphitheatre' box.

\section{ELECTRONIC RESOURCES}

British Museum Collection Online, http://www.britishmuseum.org/research/collection_on line/search.aspx.

Eighteenth-Century Collections Online, http://find.galegroup.com/ecco/.

Myers, Victoria, O'Shaughnessy, David, and Philp, Mark (eds), The Diary of William Godwin (Oxford: Oxford Digital Library, 2010), http://godwindiary.bodleian.ox.ac.uk.

Newman, Ian, London Corresponding Society Meeting Places: Exploring the 1790s Alehouse, http://www.1790salehouse.com/.

Norfolk Museums Catton Collection, http://www.museums.norfolk.gov.uk/Research/Collec tions/Fine_Art_Collections/The_Catton_Collection/index.htm.

Oxford Dictionary of National Biography (Oxford: Oxford University Press, 2004-), http:// www.odnb.com.

Royal Museums Greenwich Collections, http://collections.rmg.co.uk/collections.html. 
OUP UNCORRECTED PROOF - REVISES, 9/10/2017, SPi

\section{PERIODICALS}

Blackwood's Edinburgh Magazine (1817-1905).

British Critic (1793-1815).

British Stage and Literary Cabinet (1817-22).

Cheshire Observer and General Advertiser (1854-63).

Court Magazine and Belle Assemblée (1832-6).

Crypt, or, Receptacle for Things Past (1827-8).

Daily Advertiser (1731-98).

Daily Courant (1702-35).

Daily Post (1719-46).

Diary, or, Woodfall's Register (1789-93).

Drama; Or, Theatrical Pocket Magazine (1821-6).

Edinburgh Annual Register (1808-26).

Edinburgh Magazine, or, Weekly Amusement (1779-83).

English Review, or, An Abstract of English and Foreign Literature (1783-96).

European Magazine and London Review (1782-1825).

Evening Telegraph (Dundee, 1877-1905).

Examiner; a Sunday Paper (1808-36).

Gazetteer and New Daily Advertiser (1764-96).

General Evening Post (1733-1822).

General Magazine and Impartial Review (1787-92).

Gentleman's Magazine (1731-1922).

Hampshire Advertiser (1860-1923).

Hampshire Telegraph, and Sussex Chronicle (1803-99).

Illustrated London News (1842-).

La Belle Assemblée; or, Bell's Court and Fashionable Magazine (1806-32).

Literary Chronicle and Weekly Review (1819-28).

Literary Gazette, and Journal of Belles Lettres, Arts, Sciences, etc. (1817-62).

London Evening Post (1727-1806).

London Magazine (1820-9).

London Recorder, and Sunday Gazette (1783-95).

Monthly Review; or, Literary Journal (1749-1844).

Morning Chronicle and London Advertiser (1780-1800).

Morning Herald and Daily Advertiser (1780-5).

Morning Post (1772-1937).

Musical Times and Singing Class Circular (1844-1903).

Musical World: a Weekly Record of Musical Science, Literature, and Intelligence (1836-90).

Newcastle Weekly Courant (1884-1902).

New Monthly Magazine and Literary Journal (1821-36).

News (1805-35).

New York Mirror, and Ladies' Literary Gazette (1824-42).

Nottingham Evening Post (1878-1963).

Observer (1791-).

Oracle and Public Advertiser (1794-8).

Pall Mall Gazette (1865-1921).

Parker's General Advertiser and Morning Intelligencer (1776-82).

Penny Illustrated Paper and Illustrated Times (1861-1913).

Pic Nic (1803). 
Public Advertiser (1752-94).

Punch (1841-1992).

Quarterly Review (1809-1967).

Reading Mercury and Oxford Gazette (1767-1831).

Satirist, Or, Monthly Meteor (1808-14).

Spectator (1711-14).

Spectator (1828-).

Standard (1827-1920).

Star and Evening Advertiser (1788-1800).

St. James' Chronicle; or the British Evening Post (1761-1866).

Theatrical Inquisitor (1812-20).

Theatrical Observer: and Daily Bills of the Play (1822-36).

Theatrical Repertory, or Weekly Rosciad (1801-2).

The Times (1788-).

Tomahawk, or Censor General (1795-6).

True Briton (1793-1804).

Westminster Magazine, or, Pantheon of Taste (1773-85).

Whitehall Evening Post (1718-1801).

World (1787-94).

\section{CORRESPONDENCE AND LIFE-WRITING}

Angelo, Henry, Reminiscences of Henry Angelo, 2 vols (London, 1828).

Anon., Truth Opposed to Fiction, or, An Authentic and Impartial Review of the Life of the Late Earl of Barrymore by a Personal Observer (London, 1793).

Austen-Leigh, J. E., A Memoir of Jane Austen, ed. Kathryn Sutherland (Oxford: Oxford University Press, 2002).

Boswell, James, The Life of Samuel Johnson, ed. R. W. Chapman (Oxford: Oxford University Press, 1980).

Brown, Eluned (ed.), The London Theatre, 1811-1866: Selections from the diary of Henry Crabb Robinson (London: Society for Theatre Research, 1966).

Crosby, Benjamin, Crosby's Pocket Companion to the Playhouses. Being the Lives of All the Principal London Performers (London, 1796).

Dawe, George, The Life of George Morland, with Remarks on His Works (London, 1807).

Farington, Joseph, The Diary of Joseph Farington, ed. Kathryn Cave, 16 vols (New Haven: Yale University Press, 1982).

Farington, Joseph, The Diary of Joseph Farington, Index Volume, ed. Kathryn Cave (New Haven: Yale University Press, 1998).

Gardiner, William, Music and Friends: or, Pleasant Recollections of a Dilettante, 2 vols (London, 1838).

Holcroft, Thomas, Memoirs of the Late Thomas Holcroft, 3 vols (London, 1816).

Knight, Charles, Passages of a Working Life During Half a Century, 3 vols (London, 1864).

Lee, Henry, Memoirs of a Manager; or, Life's Stage with New Scenery, 2 vols (Taunton, 1830).

Le Faye, Deirdre, Jane Austen: A Family Record (2nd edn, Cambridge: Cambridge University Press, 2004).

Le Faye, Deirdre, Jane Austen's Letters (4th edn, Oxford: Oxford University Press, 2011).

Lisle, Mary, 'Long, Long Ago:' An Autobiography (London, 1856).

Mathews, Ann, Memoirs of Charles Mathews, Comedian, 4 vols (London, 1839). 
Morpurgo, J. E. (ed.), The Autobiography of Leigh Hunt (London: The Cresset Press, 1959).

Munden, T. S., Memoir of Joseph Shepherd Munden, Comedian (London, 1846).

Nelson, Alfred L. and Cross, Gilbert B. (eds), Selections from James Winston's Diaries 1819-1827 (London: Society for Theatre Research, 1974).

O'Keeffe, John, Recollections of the Life of John O'Keefe, written by himself, 2 vols (London, 1826).

Pasquin, Anthony [John Williams], The Life of the Late Earl of Barrymore (London, 1793).

Peake, Richard Brinsley, Memoirs of the Colman Family, Including their Correspondence (London, 1841).

Phillips, Henry, Musical and Personal Recollections during Half a Century, 2 vols (London, 1864).

Thorn, Henry G., Charles Dibdin, one of Southampton's Sons (Southampton and London, 1888).

Thornbury, Walter, The Life of J. M. W. Turner, 2 vols (1862, repr. Cambridge: Cambridge University Press, 2013).

\section{NOVELS AND POETRY}

Austen, Jane, Mansfield Park (London, 1814).

Bloomfield, Robert, The Works of Robert Bloomfield (London, 1867).

Bloomfield, Robert, Selected Poems: Revised and Enlarged Edition, ed. John Lucas and John Goodridge (Nottingham: Trent Editions, 2007).

Burney, Frances, The Wanderer (London, 1814).

Edgeworth, Maria, Patronage (London, 1814).

Haywood, Eliza, The Mercenary Lover; or, the Unfortunate Heiresses... To which is added, The Padlock; or, no guard without virtue. A Novel. (London, 1728).

Pasquin, Anthony [John Williams], The Children of Thespis (London, 1786).

Prior, Matthew, 'An English Padlock' (London, 1705).

Wolcot, John, The Works of Peter Pindar, Esq., 5 vols (New edn, London, 1812).

\section{PLAYS}

Federico, Gennaro Antonio, The Servant Mistress (London, 1770).

Foote, Samuel, A Trip to Calais: A Comedy in Three Acts... to which is annexed, 'The Capuchin' (London, 1778).

Garrick, David, Bon Ton; or, High life above stairs (London, 1775).

O'Hara, Kane, Midas. A Burletta (London, [1790]).

Pocock, Isaac, Hit or Miss! A Musical Farce in Two Acts (London, 1811).

Powell, James, The Narcotic and Private Theatricals. Two Dramatic Pieces by James Powell of the Custom House (London, [1791]).

\section{SONGBOOKS}

Aikin, John, Essays on Song-Writing. With a collection of such English songs as are most eminent for poetical merit (London, 1810).

Anon. The Favourite Songs in La Serva Padrona (London, 1759).

Anon. The Vocal Encyclopedia (London, 1808).

Collins, William, The New Vocal Miscellany, or, a Fountain of Pure Harmony (London, 1787). 
Cruikshank, George and Cruikshank, Robert, The Universal Songster, or, Museum of Mirth: forming the Most Complete, Extensive, and Valuable Collection of Ancient and Modern Songs, 3 vols (London, 1825-6).

Plumptre, James, A Collection of Songs, Moral, Sentimental, Instructive, and Amusing (London, 1805).

Plumptre, James, A Collection of Songs, Moral, Sentimental, Instructive, and Amusing, 3 vols (London, 1824).

\section{OTHER PRIMARY LITERATURE}

‘Aleph' [William Harvey], London Scenes and London People (London, 1863).

Anon. The Theatrical Review; or, New Companion to the Play-house, 2 vols (London, 1772).

Anon. The Surprising History of a Ballad Singer (Falkirk, 1818).

Archer, William and Lowe, Robert W. (eds), Dramatic Essays by Leigh Hunt (London, 1894).

Baring-Gould, Sabine, Strange Survivals: Some Chapters in the History of Man (2nd edn, London, 1894).

Beattie, James, Essays on the Nature and Immutability of Truth, in Opposition to Sophistry and Scepticism, 2 vols (Dublin, 1778).

Collins, William, Memoirs of a Picture: Containing the Adventures of Many Conspicuous Characters, 3 vols (London, 1805).

Cooper, Anthony Ashley, Earl of Shaftesbury, Characteristicks of Men, Manners, Opinions, Times, 2 vols (London, 1711, repr. Gloucester, MA: Peter Smith, 1963).

Fordyce, James, Sermons to Young Women (Dublin, 1767).

Graves, Richard, Senilities; or, Solitary Amusements: In Prose and Verse: With a Cursory Disquisition on the Future Condition of the Sexes (London, 1801).

Haweis, Hugh Reginald, Music and Morals (4th edn, London, 1873).

Hill, John, The Rout. A Farce (London, 1758?).

Hook, Theodore, Music Mad. A Dramatic Sketch (London, 1808).

Hook, Theodore, Gilbert Gurney, 3 vols (London, 1836)

Hunt, Leigh, Critical Essays on the Performers of the London Theatres including General Observations on the practise and genius of the stage (London, 1807).

Jackson, William, Sodom and Onan, a satire (London, 1776).

Jackson, William, Observations on the Present State of Music in London (London, 1791).

Lysons, Daniel, The Environs of London: Being an Historical Account of the Towns, Villages, and Hamlets, within Twelve Miles of that Capital, 4 vols (London, 1795-6).

Malton, Thomas, A Picturesque Tour through the Cities of London and Westminster, Illustrated with the Most Interesting Views, Accurately Delineated and Executed, 2 vols (London, 1792).

Molleson, Alexander, Miscellanies in Prose and Verse (Glasgow, 1806).

More, Hannah, The Two Shoemakers. In Six Parts (London, c.1800).

Palmer, Joseph, A Fortnight's Ramble to the Lakes in Westmoreland, Lancashire, and Cumberland (London, 1792).

Pasquin, Anthony [John Williams], The Pin-Basket to the Children of Thespis (London, 1797).

Playbill, For One Night Only. Sans Souci. The Inhabitants of Harrogate and its Vicinity are Respectfully Informed, that on Wednesday, July 23, 1800, at the Theatre, Harrogate, will be performed, A New and Popular Entertainment, called Tom Wilkins (Knaresborough, 1800).

Plumptre, James, Letters to John Aikin, M.D. on his volume of Vocal Poetry (Cambridge and London, 1811). 
Rede, Thomas Leman, The Road to the Stage, or the Performer's Preceptor (London, 1827).

Shepherd, R. H. (ed.), The Complete Works in Prose and Verse of Charles Lamb (London, 1878).

Smith, Charles Manby, The Little World of London; or, Pictures in Little of London Life (London, 1857).

Smith, John Thomas, A Book for a Rainy Day (London, 1845).

\section{SECONDARY WORKS}

Altick, Richard, The Shows of London (Cambridge, MA: Belknap Press, 1978).

Anderson, Benedict, Imagined Communities: Reflections on the Origin and Spread of Nationalism (Revised edn, London: Verso, 2006).

Arundell, David, The Story of Sadler's Wells 1683-1964 (London: Hamish Hamilton, 1965).

Aspinall, Arthur, Politics and the Press, c.1780-1850 (London: Home \& Van Thal, 1949).

Barker, Hannah, Newspapers, Politics, and Public Opinion in Late Eighteenth-Century England (Oxford: Oxford University Press, 1998).

Barrell, John, The Spirit of Despotism: Invasions of Privacy in the 1790s (Oxford: Oxford University Press, 2006).

Bashford, Christina, 'Learning to Listen: Audiences for Chamber Music in Early Victorian London', Journal of Victorian Culture 4 (1999): 25-51.

Bashford, Christina, The Pursuit of High Culture: John Ella and Chamber Music in Victorian London (Woodbridge: Boydell \& Brewer, 2007).

Battestin, Martin C. with Battestin, Ruth R., Henry Fielding: A Life (London: Routledge, 1989).

Beaven, Brad et al. (eds), Port Cities and Urban Cultures (Basingstoke: Palgrave Macmillan, 2015).

Bellamy, Martin, 'Financing the Preservation of Historic Ships', Mariner's Mirror 97 (2011): 344-65.

Bennett, Anthony, 'Broadsides on the Trial of Queen Caroline: A Glimpse at Popular Song in 1820', Proceedings of the Royal Musical Association 107 (1980-1): 71-85.

Bermingham, Ann, Learning to Draw: Studies in the Cultural History of a Polite and Useful Art (New Haven and London: Yale University Press, 2000).

Black, Jeremy, The English Press in the Eighteenth Century (Beckenham: Croom Helm, 1987).

Bligh, N. M., 'Mirror Curtains', Theatre Notebook 15/2 (1960-1): 56.

Bloechl, Olivia, Kallberg, Jeffrey, and Lowe, Melanie (eds), Rethinking Difference in Musical Scholarship (Cambridge: Cambridge University Press, 2015).

Booth, Michael R. (ed.), English Plays of the Nineteenth Century V. Pantomimes, Extravaganzas and Burlesques (Oxford: Oxford University Press, 1976).

Bowers, Toni, Force or Fraud: British Seduction Stories and the Problem of Resistance (Oxford: Oxford University Press, 2011).

Bratton, Jacky, The Victorian Popular Ballad (Totowa, NJ: Rowman and Littlefield, 1975).

Bratton, Jacky (ed.), Music Hall: Performance and Style (Milton Keynes: Open University Press, 1986).

Bratton, Jacky, Acts of Supremacy: The British Empire and the Stage, 1790-1930 (Manchester: Manchester University Press, 1991). 
Bratton, Jacky, 'Miss Scott and Miss Macauley: "Genius Comes in all Disguises"', Theatre Survey 37 (1996): 59-74.

Bratton, Jacky, New Readings in Theatre History (Cambridge: Cambridge University Press, 2003).

Bratton, Jacky, The Making of the West End Stage: Marriage, Management and the Mapping of Gender in London, 1830-1870 (Cambridge: Cambridge University Press, 2011).

Braudy, Leo, The Frenzy of Renown: Fame \& its history (Oxford: Oxford University Press, 1986).

Brewer, John, The Pleasures of the Imagination: English Culture in the Eighteenth Century (New York: Routledge, 2013).

Bronson, Bertrand H., The Ballad as Song (Berkeley and Los Angeles: University of California Press, 1969).

Brooks, Helen E. M., "'One Entire Nation of Actors and Actresses": Reconsidering the Relationship of Public and Private Theatricals', Nineteenth Century Theatre and Film 38/2 (2011): 3-6.

Burden, Michael, 'The Wedding Masques for Anne, the Princess Royal', Miscellanea Musicologica 17 (1990): 87-113.

Burden, Michael, 'Purcell's King Arthur in the 1730s', Restoration: Studies in English Literary Culture, 1660-1700 34/1-2 (2010-11): 117-38.

Burke, Peter, Popular Culture in Early Modern Europe (London: Temple Smith, 1978).

Burling, William, Summer Theatre in London 1661-1820, and the Rise of the Haymarket Theatre (London: Associated University Presses, 2000).

Burwick, Frederick, Playing to the Crowd: London Popular Theatre, 1780-1830 (Basingstoke and New York: Palgrave Macmillan, 2011).

Byrne, Paula, Jane Austen and the Theatre (London: Hambledon Continuum, 2002).

Cannadine, David, 'The "Last Night of the Proms" in Historical Perspective', Historical Research 81 (2008): 315-49.

Carlson, Julie A., 'New Lows in Eighteenth-Century Theatre: The Rise of Mungo', European Romantic Review 18/2 (2007): 139-47.

Carlson, Marvin, The Haunted Stage: The Theatre as Memory Machine (Ann Arbor: University of Michigan Press, 2001).

Carter, Ian, Railways and Culture in Britain: The Epitome of Modernity (Manchester: Manchester University Press, 2001).

Chancellor, E. Beresford, Annals of the Strand (London: Chapman and Hall, 1912).

Chancellor, Valerie E., 'Anti-Racialism or Censorship? The 1802 Jewish Riots at Covent Garden Opera and the Career of Thomas John Dibdin', Opera Quarterly 18 (2002): $18-25$.

Chandler, James and Gilmartin, Kevin (eds), The Romantic Metropolis, The Urban Scene of British Culture, 1780-1840 (Cambridge: Cambridge University Press, 2005).

Clayton, Tim, The English Print, 1688-1802 (New Haven: Paul Mellon Centre for British Art, 1997).

Clinton-Baddeley, V. C., The Burlesque Tradition in the English Theatre after 1660 (London: Methuen \& Co., 1952, repr. 1973).

Colley, Linda, Britons: Forging the Nation 1707-1837 (2nd edn, New Haven: Yale University Press, 2005).

Connell, Philip and Leask, Nigel, Romanticism and Popular Culture in Britain and Ireland (Cambridge: Cambridge University Press, 2009).

Cowgill, Rachel, Cooper, David, and Brown, Clive (eds), Art and Ideology in European Opera: Essays in Honour of Julian Rushton (Woodbridge: The Boydell Press, 2010). 


\section{Bibliography}

Cox, Jeffrey N. (ed.), Slavery, Abolition and Emancipation: Writings in the British Romantic Period, 8 vols (London: Pickering \& Chatto, 1999-).

Cox Jensen, Oskar, Napoleon and British Song, 1797-1822 (Basingstoke and New York: Palgrave Macmillan, 2015).

D'Arcy Wood, Gillen, Romanticism and Music Culture in Britain, 1770-1840 (Cambridge: Cambridge University Press, 2010).

Davis, Jim, 'British Bravery, or Tars Triumphant: Images of the British Navy in Nautical Melodrama', New Theatre Quarterly 4 (1988): 122-43.

Davis, Jim, Comic Acting and Portraiture in Late-Georgian and Regency England (Cambridge: Cambridge University Press, 2015).

Davis, Jim and Emeljanow, Victor, Reflecting the Audience: London Theatregoing, 1840-1880 (Iowa City: University of Iowa Press, 2001).

Davis, Tracy C. and Donkin, Ellen (eds), Women and Playwriting in Nineteenth-Century Britain (Cambridge: Cambridge University Press, 1999).

Davis, Tracy C. and Holland, Peter (eds), The Performing Century: Nineteenth-Century Theatre's History (Basingstoke: Palgrave Macmillan, 2007)

Davison, Kate, 'Occasional Politeness and Gentleman's Laughter in $18^{\text {th }} \mathrm{C}$ England', Historical Journal 57 (2014): 921-45.

Deutsch, Helen, Loving Dr Johnson (Chicago: Chicago University Press, 2005).

Dibdin, Edward Rimbault, 'A Bibliographical Account of the Works of Charles Dibdin', Notes and Queries 9 (31 May 1902): 422.

Dickie, Simon, Cruelty and Laughter: Forgotten Comic Literature and the Unsentimental Eighteenth Century (Chicago: Chicago University Press, 2011).

Dickinson, H. T., British Radicalism and the French Revolution 1789-1815 (Oxford: Blackwell, 1985).

Dickinson, H. T. (ed.), Britain and the French Revolution, 1789-1815 (Basingstoke: Macmillan, 1989).

Dobson, Michael, Shakespeare and Amateur Performance: A Cultural History (Cambridge: Cambridge University Press, 2011).

D'Oench, Ellen, 'Copper into Gold': Prints by John Raphael Smith (1751-1812) (New Haven: Yale University Press, 1999).

Duff, David, Romanticism and the Uses of Genre (Oxford: Oxford University Press, 2009).

Dunsmore, Amanda (ed.), This Blessed Pot, This Earth: English Pottery Studies in Honour of Jonathan Horne (London: Paul Holberton Publishing, 2011).

Dyck, Ian, William Cobbett and Rural Popular Culture (Cambridge: Cambridge University Press, 1992).

Empson, William, Some Versions of Pastoral (London: Chatto \& Windus, 1935).

Engel, Laura, Fashioning Celebrity: Eighteenth-Century British Actresses and Strategies for Image-making (Columbus: Ohio State University Press, 2011).

Fahrner, Robert, The Theatre Career of Charles Dibdin the Elder (1745-1814) (New York: Lang, 1989).

Findlater, Richard, Joe Grimaldi, His Life and Theatre (Cambridge: Cambridge University Press, 1978).

Fiske, Roger, English Theatre Music in the Eighteenth Century (2nd edn, Oxford: Oxford University Press, 1986).

Fitzer, Anna M., "Feeling and Sense Beyond All Seeming”: Private Lines, Public Relations and the Performances of the LeFanu Circle', Nineteenth-Century Theatre and Film 38/2 (2011): 26-37. 


\section{Bibliography}

Frankau, Julia, An Eighteenth Century Artist and Engraver. John Raphael Smith: His Life and Works (London: Macmillan \& Co., 1902).

Frankau, Julia, William Ward ARA and James Ward RA: Their Lives and Works (London: Macmillan, 1904).

Freeburn, Robert D., 'Charles II, the Theatre Patentees, and the Actor's Nursery', Theatre Notebook 48/3 (1994): 148-56.

Freeman, Mark, 'The Agricultural Labourer and the "Hodge" Stereotype, c.1850-1914', Agricultural History Review 49 (2001): 172-86.

Ganev, Robin, Songs of Protest, Songs of Love: Popular Ballads in Eighteenth-Century Britain (Manchester: Manchester University Press, 2010).

Gates, Henry Louis Junior, Figures in Black: Words, Signs, and the 'Racial' Self (New York and Oxford: Oxford University Press, 1987).

Gatrell, Vic, City of Laughter: Sex and Satire in Eighteenth-Century London (London: Atlantic, 2006).

Genette, Gérard, Paratexts, trans. Jane E. Lewin (Cambridge: Cambridge University Press, 1997).

George, Mary Dorothy, Catalogue of Political and Personal Satires, 11 vols (London: Trustees of the British Museum, 1938).

Gibbs, Jenna M., Performing the Temple of Liberty: Slavery, Theatre, and Popular Culture in London and Philadelphia, 1760-1850 (Baltimore: The Johns Hopkins University Press, 2014).

Gigante, Denise, Taste: A Literary History (New Haven: Yale University Press, 2005).

Gilbert, A. N., 'Sexual Deviance and Disaster during the Napoleonic Wars', Albion 9/2 (1977): 98-113.

Gilmartin, Kevin, 'In the Theater of Counterrevolution: Loyalist Association and Conservative Opinion in the 1790s', Journal of British Studies 41/3 (2002): 291-328.

Gilmartin, Kevin, Writing Against Revolution: Literary Conservatism in Britain, 1790-1832 (Cambridge: Cambridge University Press, 2007).

Ginter, Donald E., 'The Loyalist Association Movement of 1792-93 and British Public Opinion', Historical Journal 9/2 (1966): 179-90.

Greenblatt, Stephen (general ed.), The Norton Shakespeare (New York: W. W. Norton \& Company, 1997).

Greene, Jack P. and Pole, J. R. (eds), A Companion to the American Revolution (Oxford: Blackwell, 2008).

Guest, Harriet, Small Change: Women, Learning, Patriotism, 1750-1810 (Chicago: Chicago University Press, 2000).

Harris, Jose (ed.), Civil Society in British History: Ideas, Identities, Institutions (Oxford: Oxford University Press, 2003).

Haslanger, Andrea, 'From Man-Machine to Woman-Machine: Automata, Fiction and Femininity in Dibdin's Hannah Hewit and Burney's Camilla', Modern Philology: Critical and Historical Studies in Literature, Medieval Through Contemporary 11/4 (2014): 788-817.

Haslett, Moyra, Byron's 'Don Juan' and the Don Juan Legend (Oxford: Oxford University Press, 1997).

Hawley, Judith and Isbell, Mary (eds), Nineteenth Century Theatre and Film 38/2, special issue 'Amateur Theatre Studies' (2011).

Hemingway, Andrew, " "The Sociology" of Taste in the Scottish Enlightenment', Oxford Art Journal 12/2 (1989): 3-35. 


\section{Bibliography}

Highfill, Philip H., Burnim, Kalman A., and Langhans, Edward A., A Biographical Dictionary of Actors, Actresses, Musicians, Dancers, Managers and Other Stage Personnel in London, 1660-1800, 16 vols (Carbondale: Southern Illinois University Press, 1973-93).

Hill, Errol, The Jamaican Stage 1655-1900 (Amherst: University of Massachusetts Press, 1992).

Holm, Bent, 'Harlequin, Holberg and the (In)visible Masks: Commedia dell'arte in Eighteenth-Century Denmark', Theatre Research International 23/2 (1998): 159-66.

Horden, John, John Freeth (1731-1808): Political ballad-writer and innkeeper (Oxford: Leopard's Head Press, 1993).

Houtchens, L. H. and C. W. (eds), Leigh Hunt's Dramatic Criticism 1808-1831 (London: Geoffrey Cumberlege, 1950).

Hunter, David, 'Music Copyright in Britain to 1800', Music \& Letters 67/3 (1986): 269-82.

Isbell, Mary, 'The Handwritten Playbill as Cultural Artifact: A French Amateur Theatrical Aboard the British Prison Ship, Crown', Inquire: A Journal of Comparative Literature 1 (2011), (accessed 13 May 2015), http://inquire.streetmag.org/articles/40.

Isbell, Mary, 'When Ditchers and Jack Tars Collide: Benefit Theatricals at the Calcutta Lyric Theatre during the Indian Mutiny of 1857-9', Victorian Literature and Culture 42 (2014): 407-23.

James, Louis, 'Taking Melodrama Seriously: Theatre, and Nineteenth-Century Studies', History Workshop 3 (1977): 151-8.

Jones, Steven E., Satire and Romanticism (Basingstoke: Macmillan, 2000).

Kelly, Ian, Mr Foote's Other Leg (London: Picador, 2012).

Kennedy, Philip F. and Warner, Marina (eds), Scheherazade's Children: Global Encounters with the Arabian Nights (New York: New York University Press, 2013).

King, Reyahn, et al. (eds), Ignatius Sancho: An African Man of Letters (London: National Portrait Gallery, 1987).

King, Richard G. and Willaert, Saskia, 'Giovanni Francesco Crosa and the First Italian Comic Operas in London, Brussels and Amsterdam, 1748-50', Journal of the Royal Musical Association 118/2 (1993): 246-75.

Kinservik, Matthew J., 'The Politics and Poetics of Sodomy in the Age of George III', British Journal for Eighteenth-Century Studies 29/2 (2006): 219-36.

Kirk, John, Noble, Andrew, and Brown, Michael (eds), United Islands? The Languages of Resistance (London: Pickering \& Chatto, 2012).

Klepac, Richard L., Mr Mathews at Home (London: Society for Theatre Research, 1979).

Knight, William, A Major London Minor: The Surrey Theatre 1805-1865 (London: Society for Theatre Research, 1997).

Knights, Mark and Morton, Adam (eds), Laughter and Satire in the Early Modern Period (London: Boydell \& Brewer, 2017).

Kriz, K. Dian, Slavery, Sugar, and Refinement: Picturing the British West Indies, 1700-1840 (New Haven: Yale University Press, 2008).

Kverndal, Roald, Seamen's Missions: Their Origins and Early Growth (Pasadena, CA: William Carey Library, 1986).

Lambert, Andrew, Trincomalee: The Last of Nelson's Frigates (Annapolis, MD: Naval Institute, 2002).

Land, Isaac, War, Nationalism, and the British Sailor, 1750-1850 (Basingstoke and New York: Palgrave Macmillan, 2009).

Lawson, Melinda, 'Imagining Slavery: Representations of the Peculiar Institution on the Northern Stage, 1776-1860', Journal of the Civil War Era 1 (2011): 25-55. 
Ledger, Allan, A Spencer Love Affair: Eighteenth-Century Theatricals at Blenheim Palace and Beyond (Gloucester: Fonthill Media, 2014).

Lewis, Brian (ed.), British Queer History: New Approaches and Perspectives (Manchester: Manchester University Press, 2013).

Littlewood, Kevin and Butler, Beverley, Of Ships and Stars: Maritime Heritage and the Founding of the National Maritime Museum Greenwich (London: Athlone, 1998).

Lockwood, Elisabeth M., 'Charles Dibdin's Musical Tour', Music \& Letters 13/2 (1932): $207-14$.

Lockwood, Elisabeth M., 'Jane Austen and some Drawing-Room Music of her Time', Music \& Letters 15/2 (1934): 112-19.

Lorenzen, Richard L., The History of the Prince of Wales Theatre, 1771-1903 (Hatfield: University of Hertfordshire Press, 2014).

Luckhurst, Mary and Moody, Jane (eds), Theatre and Celebrity in Britain, 1660-2000 (Basingstoke: Palgrave Macmillan, 2005).

Mabilat, Claire, Orientalism and Representations of Music in the Nineteenth-Century British Popular Arts (Farnham: Ashgate, 2008).

McConnell Stott, Andrew, The Pantomime Life of Joseph Grimaldi (Edinburgh: Canongate Books, 2010).

McCormack, Matthew, The Independent Man: Citizenship and Gender Politics in Georgian England (Manchester: Manchester University Press, 2005).

McCormack, Matthew, 'Rethinking "Loyalty" in Eighteenth-Century Britain', Journal for Eighteenth-Century Studies 35/3 (2012): 407-21.

Mace, Nancy A., 'Litigating the "Musical Magazine": The Definition of British Music Copyright in the 1780s', Book History 2 (1999): 122-45.

Mace, Nancy A., 'Charles Rennett and the London Music-Sellers in the 1780s: Testing the Ownership of Reversionary Copyrights', Journal of the Royal Musical Association 129 (2004): 1-23.

McGirr, Elaine and Engell, Laura (eds), Stage Mothers: Women, Work and the Theatre 1660-1830 (Lewisburg: Bucknell University Press, 2014).

Mackie, Erin (ed.), The Commerce of Everyday Life: Selections from The Tatler and The Spectator (Boston: Bedford, 1998).

Makdisi, Saree, Making England Western: Occidentalism, Race, and Imperial Culture (Chicago: University of Chicago Press, 2014).

Mayer, David, Harlequin in His Element: The English Pantomime, 1806-1836 (Cambridge, MA: Harvard University Press, 1969).

Mee, Jon, Conversable Worlds: Literature, Contention, and Community 1762 to 1830 (Oxford: Oxford University Press, 2011).

Milhous, Judith and Hume, Robert D., 'Isaac Bickerstaffe's Copyrights—and a Biographical Discovery', Philological Quarterly 83/3 (2004): 259-73.

Mole, Tom (ed.), Romanticism and Celebrity Culture, 1750-1850 (Cambridge: Cambridge University Press, 2009).

Moody, Jane, Illegitimate Theatre in London, 1770-1840 (Cambridge: Cambridge University Press, 2000).

Moody, Jane and O'Quinn, Daniel (eds), The Cambridge Companion to British Theatre, 1730-1830 (Cambridge: Cambridge University Press, 2007).

Morgan, Simon, 'Celebrity: Academic “Pseudo-Event" or a Useful Concept for Historians?' Cultural and Social History 8 (2011): 95-114.

Mori, Jennifer, 'Languages of Loyalism: Patriotism, Nationhood and the State in the 1790s', English Historical Review 118 (2003): 33-58. 
Mulvihill, James, 'William Hazlitt on Dramatic Text and Performance', Studies in English Literature, 1500-1900 41/4 (2001: 'The Nineteenth Century'): 695-709.

Munns, Jessica and Richards, Penny (eds), The Clothes That Wear Us (Newark: University of Delaware Press, 1999).

Murphy, Hugh and Oddy, Derek J., The Mirror of the Seas: A Centenary History of the Society for Nautical Research (London: Society for Nautical Research, 2010).

Nathan, Hans, 'Negro Impersonation in Eighteenth Century England', Notes, 2nd series, 2/4 (1945): 245-54.

Newman, Ian, 'Civilizing Taste: "Sandman Joe", the Bawdy Ballad, and Metropolitan Improvement', Eighteenth-Century Studies 48/4 (2015): 437-56.

Novak, Maximillian E., 'Ideological Tendencies in Three Crusoe Narratives by British Novelists during the Period Following the French Revolution: Charles Dibdin's Hannah Hewit, The Female Crusoe, Maria Edgeworth's Forester, and Frances Burney's The Wanderer', Eighteenth-Century Novel 9 (2012): 261-80.

Nussbaum, Felicity, The Limits of the Human: Fictions of Anomaly, Race, and Gender in the Long Eighteenth Century (Cambridge: Cambridge University Press, 2003).

Nussbaum, Felicity, Rival Queens: Actresses, Performance and the Eighteenth-Century British Theater (Philadelphia: University of Pennsylvania Press, 2010).

O'Brien, John, Harlequin Britain: Pantomime and Entertainment, 1690-1760 (Baltimore: The Johns Hopkins University Press, 2004).

O'Connell, Sheila, 'Humorous, Historical and Miscellaneous: Mezzotints, One Shilling Plain, Two Shillings Coloured', Publishing History 70 (2011): 83-100.

Oldfield, John R., "'The Soft Ties of Humanity": Slavery and Race in British Drama, 1760-1800', Huntington Library Quarterly 56 (1993): 1-14.

Oldfield, John R., Popular Politics and British Anti-slavery: The Mobilisation of Public Opinion Against the Slave Trade, 1787-1807 (Manchester: Manchester University Press, 1995).

O'Quinn, Daniel, Staging Governance: Theatrical Imperialism in London 1770-1800 (Baltimore: Johns Hopkins University Press, 2005).

O'Quinn, Daniel, Entertaining Crisis in the Atlantic Imperium 1770-1790 (Baltimore: Johns Hopkins University Press, 2011).

O'Shaughnessy, David, William Godwin and the Theatre (London: Pickering \& Chatto, 2010).

Partington, Wilfred, Charles Dibdin: The Man whose Songs helped to Win the Battle of Trafalgar, and who did not allow the Nation to forget it, either (London: Chiswick Press, 1944).

Pastoureau, Michel, The Devil's Cloth: A History of Stripes and Striped Fabric, trans. Jody Gladding (New York: Columbia University Press, 1991).

Philp, Mark (ed.), The French Revolution and British Popular Politics (Cambridge: Cambridge University Press, 1991).

Philp, Mark, 'Vulgar Conservatism, 1792-3', English Historical Review 110 (1995): 42-69.

Philp, Mark, Reforming Ideas in Britain; Politics and Language in the Shadow of the French Revolution, 1789-1815 (Cambridge: Cambridge University Press, 2014).

Piper, Andrew and Sachs, Jonathan, 'Introduction: Romantic Cultures of Print-From Miscellaneity to Dialectic', Romanticism and Victorianism on the Net 57-8 (2010). doi: 10.7202/1006508ar.

Pointon, Marcia, 'Portrait Painting as a Business Enterprise in London in the 1780s', Art History 7 (1984): 187-205. 
Prochaska, Frank K., 'Charity Bazaars in Nineteenth-Century England', Journal of British Studies 16 (1977): 62-84.

Redford, Duncan, The Submarine: A Cultural History from the Great War to Nuclear Combat (London: I. B. Tauris, 2010).

Ritchie, Leslie, 'The Spouters' Revenge: Apprentice Actors and the Imitation of London's Theatrical Celebrities', The Eighteenth Century 53 (2012): 41-71.

Robinson, Andrew, The Last Man Who Knew Everything (London: Oneworld, 2006).

Robinson, John R., The Last Earls of Barrymore, 1769-1824 (London, 1894).

Rogers, Nicholas, 'Burning Tom Paine: Loyalism and Counter-Revolution in Britain, 1792-1793', Histoire Sociale/Social History 32 (1999): 139-71.

Rojek, Chris, Celebrity (London: Reaktion, 2001).

Ronald, D. A. B., Youth, Heroism and War Propaganda: Britain and the Young Maritime Hero, 1745-1820 (London: Bloomsbury, 2015).

Rosenfeld, Sybil, 'A Sadler's Wells Scene Book', Theatre Notebook 15/2 (1960-1): 57-62.

Rosenfeld, Sybil, Temples of Thespis: Some Private Theatricals in England and Wales, 1700-1820 (London: Society for Theatre Research, 1978).

Russell, Gillian, Women, Sociability and the Theatre in Georgian London (Cambridge: Cambridge University Press, 2007).

Russell, Gillian and Tuite, Clara (eds), Romantic Sociability: Social Networks and Literary Culture in Britain 1770-1840 (Cambridge: Cambridge University Press, 2002).

Saggini, Francesca, Backstage in the Novel: Frances Burney and the Theatre Arts, trans. Laura Kopp (Charlottesville and London: University of Virginia Press, 2012).

Saxon, A. H., 'The Circus as Theatre: Astley's and Its Actors in the Age of Romanticism', Educational Theatre Journal 27/3 (1975): 299-312.

Scott, Derek B., The Singing Bourgeois: Songs of the Victorian Drawing Room and Parlour, (2nd edn, Aldershot: Ashgate, 2001).

Scott, Derek B., 'Music and Social Class in Victorian London', Urban History 29 (2002): 60-73.

Semmel, Stuart, 'Reading the Tangible Past: British Tourism, Collecting, and Memory after Waterloo', Representations 69 (2000): 9-37.

Shaw, Philip (ed.), Romantic Wars: Studies in Culture and Conflict, 1793-1822 (Aldershot: Ashgate, 2000).

Shir-Jacob, Anita, 'Staging the British Empire under Charles Dibdin the Younger at Sadler's Wells, 1800-1819', in Ros Merkin (ed.), Popular Theatres? Papers from the Popular Theatre Conference, Liverpool, John Moores University, 1994 (Liverpool: John Moores University, 1996), 190-205.

Simpson, David, Romanticism, Nationalism, and the Revolt Against Theory (Chicago: Chicago University Press, 1993).

Smith, Michael S., 'Anti-Radicalism and Popular Politics in an Age of Revolution', Parliamentary History 24 (2005): 71-92.

Solkin, David H., Painting for Money: The Visual Arts and the Public Sphere in EighteenthCentury England (New Haven and London: Yale University Press, 1992).

St Clair, William, The Reading Nation in the Romantic Period (Cambridge: Cambridge University Press, 2004).

Stephens, John Russell, The Profession of the Playwright: British Theatre 1800-1900 (Cambridge: Cambridge University Press, 1992).

Stewart, David, 'Filling the Newspaper Gap: Leigh Hunt, Blackwood's, and the Development of the Miscellany', Victorian Periodicals Review 42/2 (2009): 155-70.

Stewart, David, Romantic Magazines and Metropolitan Literary Culture (Basingstoke and New York: Palgrave Macmillan, 2011). 


\section{Bibliography}

Stone, George W. Jr (ed.), The London Stage, 1660-1800, Part 4, 1747-1776, (Carbondale: Southern Illinois University Press, 1962).

Swindells, Julia and Taylor, David Francis (eds), The Oxford Handbook of the Georgian Theatre, 1737-1832 (Oxford: Oxford University Press, 2014).

Tasch, Peter A., 'Garrick's Revisions to Bickerstaff's The Sultan', Philological Quarterly 50 (1971): 141-9.

Tasch, Peter A., The Dramatic Cobbler: The Life and Works of Isaac Bickerstaff (Lewisburg: Bucknell University Press, 1972).

Taylor, David Francis, Theatres of Opposition: Empire, Revolution, and Richard Brinsley Sheridan (Oxford: Oxford University Press, 2012).

Thompson, E. P., The Making of the English Working Class (London: Penguin, 1963; 1970).

Thompson, E. P., Customs in Common (Harmondsworth: Penguin, 1993).

Thompson, Judith, 'From Forum to Repository: A Case Study in Romantic Cultural Geography', European Romantic Review 15/2 (2004): 177-91.

Walser, Richard, 'Negro Dialect in Eighteenth-Century American Drama', American Speech 30/4 (1955): 269-76.

Wanko, Cheryl, Roles of Authority: Thespian Biography and Celebrity in Eighteenth-Century Britain (Lubbock: Texas Tech University Press, 2003).

Warhol-Down, Robyn (ed.), The Work of Genre: Selected Essays from the English Institute (Cambridge, MA: English Institute in collaboration with the American Council of Learned Societies, 2011).

Weber, William, 'Canonicity and Collegiality: "Other" Composers, 1790-1850', Common Knowledge 14 (2008): 105-23.

Weber, William, The Great Transformation of Musical Taste: Concert Programming from Haydn to Brahms (Cambridge: Cambridge University Press, 2008).

Werkmeister, Lucyle, The London Daily Press 1772-1792 (Lincoln: University of Nebraska Press, 1963).

Wheeler, H. F. B. and Broadley, A. M., Napoleon and the Invasion of England: The Story of the Great Terror, 2 vols (London: John Lane, 1908).

Wilbourne, Emily, 'Lo Schiavetto (1612): Travestied Sound, Ethnic Performance, and the Eloquence of the Body', Journal of the American Musicological Society 63 (2010): 1-43.

Williams, Raymond, The Country and the City (London: Chatto \& Windus, 1973).

Wilson, Kathleen, The Sense of the People: Politics, Culture and Imperialism in England, 1715-1785 (Cambridge: Cambridge University Press, 1995).

Wilson, Kathleen, Strolling Players of Empire: Theater, Culture and Modernity in the British Provinces, 1720-1820 (Cambridge: Cambridge University Press, 2016).

Woodfield, Ian, Opera and Drama in Eighteenth-Century London: The King's Theatre, Garrick, and the Business of Performance (Cambridge: Cambridge University Press, 2001).

Worrall, David, Theatric Revolution: Drama, Censorship and Romantic Period Subcultures 1773-1832 (Oxford: Oxford University Press, 2006).

Worrall, David, Harlequin Empire; Race, Ethnicity, and the Drama of the Popular Enlightenment (London: Pickering \& Chatto, 2007).

Worrall, David, The Politics of Romantic Theatricality, 1787-1832: The Road to the Stage (Basingstoke: Palgrave Macmillan, 2007).

Yeandle, Peter, Newey, Katherine, and Richards, Jeffrey (eds), Politics, Performance and Popular Culture: Theatre and Society in Nineteenth-Century Britain (Manchester: Manchester University Press, 2016). 


\section{Index}

Abolitionism, see Slavery

Ackermann, Rudolph (1764-1834) 165-6

Addison, Joseph (1672-1719) 67, 70, 75, 117, 166,187

Adelphi theatre 173. See also Sans Pareil theatre

Aikin, John (1747-1822) 116

Albert, Prince of Saxe-Coburg and Gotha (1819-61) 209

Aldridge, Ira (1807?-67) 24

Aleph, see Harvey, William

Anacreontic Society 161, 163-4

Andrews, Robert, scene painter 174-8

Anecdote (as genre) 4-5, 89, 105

Angelo, Henry Charles William (1756-1835) 98n, 164

Aquatic theatre 172-4, 182-3, 188

Army, British 85-6, 90, 97, 111

Arne, Thomas (1710-78) 71n

Association for the Preservation of Liberty and Property 86

Astley, John (1768-1821) 183

Astley, Philip (1742-1814) 12, 16, 43, 45-6, 48,53

Astley's Amphitheatre 43, 45, 183, 186

Austen, Jane (1775-1817) 2, 17, 98n, 99, 100,

Austria 24 $108-12$

Balfe, Michael William (1808-70) 212-14

Ballad singers 16, 118, 127-8, 131, 146, 222. See also Broadside ballads

Bannister, Charles (1741-1804) 161, 163

Baring-Gould, Sabine (1834-1924) 132

Barrett, William Alexander (1836-91) 133

Barry, Richard, 7th Earl of Barrymore (1769-93) 96, 98-9, 100

Bate, Sir Henry Dudley (1745-1824) 36, 68n, 69-70

Beard, John (1716/17-91) 12

Beattie, James (1735-1803) 25

Beethoven, Ludwig van (1770-1827) 206

Belgium 175

Bell, John, journalist (1745-1831) 76

Berlioz, Hector (1803-69) 212

Bickerstaff, Isaac (1733-after 1808) 2, 3, 11-12, $17,23-4,27,40,78-9,83,143$

Blackface, see Race, also Dibdin, Charles: Mungo (role of)

Blake, William (1757-1827) 7

Bland, Maria, née Romanzini (1769-1838) 49-50, 54

Bloomfield, Robert (1766-1823) 6, 17, 59-63

Bostock, Robert, printer 79, 83
Boyce, William (1711-79) 55, 136

Braham, John (1777?-1856) 15, 193

Britton, John (1771-1857) 124, 126

Broadside ballads 15-16, 18, 127-8, 222

Brunias, Agostino (1730?-96) 30

Burgoyne, John (1723-92) 71n, 72

Burke, Edmund (1729/30-97) 14, 117-18

Burney, Charles (1726-1814) 14, 100, 166

Burney, Frances (1776-1828) 98n, 100

Burns, Robert (1759-96) 6, 132, 210

Byron, George, 6th Baron (1788-1824) 132, 173,184

Campbell, Thomas (1777-1844) 212-13

Caribbean 26, 30, 37, 39, 94

Catnach, James ('Jemmy') (1792-1841) 15, 16

Catton, Charles the Elder (1728-98) 144, 154,156

Celebrity 80, 82, 84

Cervantes, Miguel de (1547?-1616) 23-4

Cherry, Andrew (1762-1812) 191

Child actors 47-50, 54-5, 172

Church of England, see Religion

Cibber, Theophilus (1703-58) 48

Clamp, Robert, artist 151-2

Clint, Luke, scene painter 174-5

Cobb, Geoffrey Wheatley, businessman 216, 218

Cobb, Gerald (1838-1904) 204

Cobb, James (1756-1818) 191

Cobbett, William (1763-1835) 115

Coburg theatre 172, 179

Coleridge, Samuel Taylor (1772-1834) 1n, 7

Collins, William, art dealer 161, 163-4

Colman, George the Elder (1732-94) 12

Colman, George the Younger (1762-1836) 15, $54,191,196-8,201$

Commercial Treaty, Anglo-French (1786) 73, 76,87

Common Pleas, Court of 79

Cooke, Thomas Potter (1786-1864) 134

Covent Garden theatre 4, 7, 12, 13, 16, 24, 39, $54,156,164,174,189,193-5,201$

Cowley, Hannah (1743-1809) 71n, 74, 104

Cowper, William (1731-1800) 117n

Craven, Elizabeth, Margravine of Ansbach (1750-1828) 95-7, 104

Crosby, Benjamin, writer 142-3

Crown and Anchor Tavern 164

Cruikshank, George (1792-1878) 16, 209

Cruikshank, Isaac (1756-1811) 16, 144, 156

Cummings, William Hayman (1831-1915) 136 
Daly, Richard (1758-1813) 66, 73, 75

Daniel, George, writer 193

Davenport, John, printer 127-8

Davenport, Mary Ann (1759-1843) 118

Davidson, George H., writer 209-10

Delaval, Sir Francis Drake (d.1826) 96

Dialect 26, 32, 36-8, 59-63, 89, 111, 138, 140, 197, 209

Dibdin, Anne (1776-?) 163, 165-6

Dibdin, Charles Isaac Mungo (1768-1833) 11, $18,26,58,171-88,223$

Dibdin, Charles the Elder (1745-1814)

and the law $12-13,17,48,55-7,66,72$, $78-9,83-4,89,92$

and the press $4,17,31,45,48-9,52,55-7$, $64-77,78-9,81,82-4,86-7,99$, $101-2,105-6,116,124,141-3,153$

and the sea $1,4,8,18,63,85-6,90,111$, $115-16,122-4,128-36,137-40$, $143,146,163,204-19,225-6$

audience $13,15-16,26,32,36,45,70$, 73-4, 81-2, 84, 87, 90-3, 102, 106, $124-8,131,137,146,157,204$, 206-7, 222-7

business dealings $4,43-6,55-8,66,75-6$, $90,99,101,105-6,119,123,126-7$ $130,145-6,153,158,164,167$, 204, 223

collaborations 11-14, 24, 43-6, 50, 53-4, $55-8,66,67 \mathrm{n}, 73,78,130$

education 60

as 'genius' 6, 205, 210

government pension 1, 90-1, 129, 207, 226

legacy $6,15,18,23,81,85,115,132-6,187$, 204-19

Mungo, role of $1,3,9,16,23-36,41-2$, $141-2,144$

painting 164-6

performance, see solo entertainments

politics $8-9,17,39,42,52,65-77,79$ $84-93,103,105,110-11,128-9$, $139-40,207,222-7$

private life $118,206-7,223$

reputation and character $1,3,5,15,17,37$, $41,60,65,75-6,78-93,106$, $115-16,143,145-6,165-7,171$, $187,205-6,223,226$

solo entertainments $3-4,13,17,37-8$, 79-93, 95, 101-6, 118, 124-6, $137-43,153,164,206,223-7$

songwriting $81,116-24,128,130,137,143$

tours $2,39,76,103,124,126-7,140,146$,

works $164-7,224$

Books

Complete History of the English Stage 4, 14

Hannah Hewitt 2, 4

The Harmonic Preceptor 109

Musical Mentor 11, 17, 108-9
Musical Tour 9, 14, 39, 104, 122-3

Observations 14, 81-2, 140, 164-6

Professional Life 1, 3-6, 11-13, 55, 58, 60, $66,73,75,83,127,130,139,146$, 163-4, 166-7, 226

The Public Undeceived 90

The Royal Circus Epitomized 55-7

The Younger Brother 4, 66

Collections

British War Songs 90-1

The Feast of Reason (unpublished) $101 \mathrm{n}$

Periodicals

By-Stander 4, 75-7, 87

Devil 4, 17, 65-77, 87-8

How Do You Do? 105-6

Full productions

The Blackamoor Wash'd White 23, 36-7

The Captive 11, 23, 40

The Cestus 49

The Comic Mirror 12

The Ephesian Matron 11

The Fairy World 49, 56

The Graces 54

He Would If He Cou'd 11

The Islanders 225

The Jubilee 13, 73, 127

The Lancashire Witches 3

Liberty Hall 123, 161

Lionel and Clarissa 11

Love in the City 11

The Magic of Orosmanes 16, 23, 38-9, 52-3

The Padlock 3, 9, 11, 23-36, 39, 41, 78

Poor Vulcan! 54

The Recruiting Sarjeant 11

Robinson Crusoe 105n

The Seraglio 16, 23, 40

The Sultan 11, 23, 40-1

The Touchstone 3

The Waterman 12, 223

Vineyard Revels 3

Will o' the Wisp 62

Solo productions

Britons Strike Home 91

Castles in the Air 82, 89, 224

Christmas Gambols 137, 141, 143, 153

Great News 87-8

The Oddities 163

Private Theatricals 8, 94, 101-5

The Quizzes 86

A Tour to the Land's End 119, 124, 126

The Whims of the Moment 103

Songs

'The Advantage of Toping' 151

'Bachelor's Hall' 108, 110

'The Battle of Corunna' 209

'Bill Bobstay' 8-9, 103

'Blow high, blow low' 147

'The Bumpkin in Town' 62-3 
'The Can of Grog' 213-14

'The Compact of Freedom' 86-7

'Constancy' 109

'Dear Yanko Say' 225-6

'Divertissement' 223

'The Elopement' 158, 160, 162

'The Fair' 149

'The Gardener' 61

'The Greenwich Pensioner' 145, 149-51, 158,213

'The High-Mettl'd Racer' 161

'Jack Ratlin' 123, 129, 208

'Jack's Gratitude' 103n

'Jacky and the Cow' 141, 148

'Joltering Giles' 59

'The Joys of the Country' 63, 108, 111

'The Lamplighter' 108, 158

'Lamplighter Dick' 110, 213

'The Lucky Escape' 108, 111

'The Margate Hoy', see 'A Voyage to Margate'

'A Matrimonial Thought' 14

'Le Philosophe Sans Souci' 94n

'My Poll and My Partner Joe' 151, 158-9, 161,163

'Naval Victories' 210

'Ninety Three' 86

'Ode on the Nuptuals of the Prince and Princess of Wales' 143

'Pomposo' 209

'Poor Jack' 76, 145, 158, 205, 208, 213,215

'Poor Orra Tink' 108, 111

'A Portrait of Innocence' 109

'The Preservation of the Braganzas' 209-10

'The Rights of Man' 8

'The Sailor's Journal' 61-2

'The Sailor's Return' 103n

'The Soldier's Adieu' 108, 111

'Sound Argument' 94n, 108, 110

'Tack and Tack' 103n

'The Tinker' 61

'Tom Bowling' 3, 6, 76, 116, 143, 208, 213,219

'Tom Tackle' 224

'The Trial' 224

'True Courage' 17, 116-36, 207

'Twas Post Meridian' 213

'Vanity Reproved' 109

'A Voyage to Margate' 18, 137-44, 151, 153-4, 156-7

'The Waggoner' 61

'Wapping Old Stairs' 208

'The Woodman' 61, 108, 111

Dibdin, Thomas John (1771-1841) 11, 13, 18, $107 \mathrm{n}, 134,136,141,146,156$ 171-2, 178, 182-3, 186, 189-203, 205-6, 209, 223
Dickens, Charles (1812-70) 209

Dissent, see Religion

Dowton, William (1764-1851) 193

Doyle, Sir Arthur Conan (1859-1930) 216

Drury Lane theatre 4, 7, 12, 13, 16, 24, 36, 41, 161, 164, 174, 178, 180, 189, 195-6, 201

Duck, Stephen (1705?-56) 6, 61

Edgeworth, Maria (1768-1849) 98n

Elliston, Robert William (1774-1831) 201

Emery, John (1777-1822) 189

Fairburn, John (d.1854) 141

Farington, Joseph (1747-1821) 223, 225

Farley, Charles (1771-1859) 194

Fawcett, John (1769-1837) 192, 197

Fielding, Henry (1707-54) 100, 106, 184

Foote, Samuel (1720-77) 12, 92, 106, 141

Fordyce, James (1720-96) 109

Fores, Samuel William (1761-1838) 15-16, 66, $146,153-4,157,158$

Fox, William (1736-1826) 226

France 12, 73, 75, 76, 87, 91, 117, 129, 131, 175-7, 200. See also French Revolution

Freemasons' Tavern 74

Freeth, John (1731-1808) 89

French Revolution 8-9, 15, 76, 86, 94, 115, $117-18,222$

Friedrich II of Prussia, aka Frederick the Great (1712-86, r.1740-86) 94

Gainsborough, Thomas (1727-88) 163

Gardiner, William (1770-1853) 115

Garrick, David (1717-79) 12-14, 23n, 36, 83, 94n, 136, 141n, 166, 186, 213

Gay, John (1685-1732) 33

Gender 17, 23, 30, 33-6, 39-41, 74n, 96-7, 104-5, 108-12, 131, 174

George III (1738-1820, r.1760-1820) 73n

George IV (1762-1830, r.1820-30) 53, 76, 96, 143

Germany (music of) $117,213-14$

Gillray, James (1756-1815) 15, 30, 68, 95, 98n

Gilpin, William (1724-1804) 208

Girtin, Thomas (1775-1802) 177

Godwin, William (1756-1836) 223

Goldsmith, Oliver (1728?-74) 14, 71-2, 83

Graves, Richard (1715-1804) 98-100, 105

Great Britain

Empire 72, 75, 87, 111, 185, 214, 226. See also Caribbean, Jamaica, India, South Africa

England (regions of) 17, 26, 60, 64n, 126-8, $156,178-9,189$

England (rural) 59-63, 89, 94, 96, 98, 111,128

England 25, 37, 42, 52, 87, 104-5 


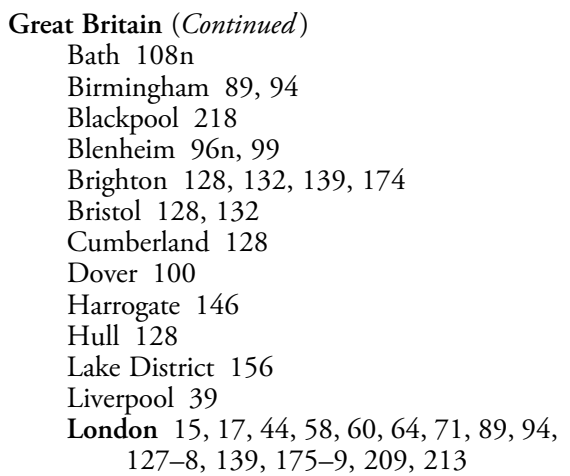

Blackfriars (Surrey side) 12, 44, 55-6, 66, 178

Charing Cross 178

Chelsea $176-7,216$

City of 124, 160, 164, 176

Ealing 118

Greenwich 176, 178, 204

Hammersmith 95, 96n

Hanover Square 210

Hoxton 101

Islington $171,180,186,188$

King Street 161, 164-5, 167

Leicester Place 119, 127, 137, 165

Leicester Square 167

St Giles's 178

St Pancras 66

Strand 94-5, 137, 153, 164-5, 167, 198

Streatham 14

Tottenham Court Road 105-6

Tottenham Street 95

Wapping 139

Well's Street 100

Westminster 178

Whitehall 95

Lyme Regis 164-5

Manchester 39

Margate 137-9, 141, 143, 156, 226

Newbury 95

Newcastle 127-8

Norwich 80, 126, 164

Oxford 14

Penrith 128

Portsmouth 213, 216

South Shields 128

Southampton 66, 124

Wargrave 96, 105

Weymouth 139

Wynnstay 96

Yarmouth 91

York 127-8, 200

Government of $52,67-8,72,79,84-5,93$, $174,185,188,198,207,222$

Ireland $66,73,75,90,100,115 \mathrm{n}, 141$, 212-13, 224
National Character 31-2, 37, 42, 63, 64, 72, 79, 86, 89-90, 98-9, 105, 111, 117, 130-1, 139-43, 179, 185, 205,

214-19, 227. See also Loyalism and Royal Navy

Scotland 115n, 127-8, 216

Wales $115 \mathrm{n}$

Grenville, William, 1st Baron Grenville (1759-1834) 90-1

Grieve, John Henderson (1770/1-1845) 174-5

Grimaldi, Giuseppe (1709?-88) 12-13, 50, 55,57

Grimaldi, Joseph (1778-1837) 12, 172, 174, 176, 182-3, 194, 199, 201

Hague, Charles (1769-1821) 129

Haiti 94

Handel, Georg Frideric (1685-1759) 54-5, $112 n, 204$

Hanover Square Rooms 210-14

Hardy, Thomas, radical (1752-1832) 225

Harlequin, figure of 27-9, 38-9, 52-3, 105, $174,176,180-1,194,198-9,201$

Harris, John, publisher (1756-1846) 164

Harris, Thomas, theatre manager (d.1820) 12 , 194

Harvey, William, aka Aleph, journalist (1796-1866) 136

Haweis, Hugh Reginald (1838-1901) 206

Hayes, Philip (1738-97) 14

Haymarket 4, 12, 39, 55, 188, 189, 191-2, $196-7,199,201$

Hays, Mary (1759-1843) 139

Haywood, Eliza (1693?-1756) 23-4

Hinton, William, publisher 144, 153

Hobart, Albinia, Countess of Buckinghamshire (1737/8-1816) 94-5, 97

Hobart, George, 3rd Earl of Buckinghamshire (1731-1804) 95n

Hogarth, George (1783-1870) 44, 80-1, $125-6,132,205,207-10$

Holcroft, Thomas (1745-1809) 194, 223

Hook, James (1746-1827) 15, 61

Hook, Theodore (1788-1841) 192

Hughes, Charles (1746/7-97) 12-13, 43-5, 50, $55-7$

Hunt, Leigh (1784-1859) 181, 189-93, 197-8, 201

Illegitimate theatre $43,48,53-8,72,95-6$, 100-1, 106-7, 171-88, 198

Inchbald, Elizabeth (1753-1821) 71n, 104, 195

Incledon, Charles (1763-1826) 131, 193

India $24-5,75,76$

Italy (music of) 2, 24, 32, 41, 54, 71, 76, 117,214

Jackson, William, composer (1730-1803) 116 Jackson, William, journalist (1737?-95) 69, 92 
Jamaica 24

Jennings, John, printer 15, 128

Johnson, Samuel (1709-84) 5, 14, 15, 74n, 82,91

Kelly, Frances Maria (1790-1882) 198-9

Kelly, Hugh (1739-77) 83

Kenney, James (1780-1849) 192

Kenyon, Lloyd, 1st Baron Kenyon (1732-1802) 99

King, Thomas (1730-1805) 12

King's Bench, Court of 78, 79, 178

King's Theatre 53, 96

Kipling, Rudyard (1865-1936) 204

Kitchiner, William (1778-1827) 126, 132, 143,145

Knight, Charles (1791-1873) 131

Knight, Edward (1774-1826) 194, 198

Kotzebue, August von (1761-1819) 195

Lamb, Charles (1775-1834) 194-6

Lancelott, Francis, composer 132-3

Laurie, Robert (1755?-1836) 15-16, 149, 157

Lee, Henry (1765-1836) 133-4

Lennox, Charles, 3rd Duke of Richmond (1735-1806) 95-6, 98

Lisle, Mary (1795-?) 131-2

Liston, John (c.1776-1845) 192, 194, 196-200

Liszt, Franz (1811-86) 212

Locke, William, journalist 78

Loutherbourg, Phillip James de (1740-1812) 39

Loyalism 2, 3, 8, 15, 76, 79, 84-93, 105, 111, $115,118,128-32,181,204,222-7$

Lyceum 158, 163, 198

Lytton, Edward Bulwer, 1st Baron (1803-73) 202

MacNally, Leonard (1752-1820) 69, 70n

Malibran, Maria (1808-36) 213

Marshall, John, London printer (1756-1824)

Marshall, John, Newcastle printer 16, 128

Mathews, Charles (1776-1835) 103n, 106n, 192, 196

Melodrama 190-1, 195-6, 201-2

Mendelssohn, Felix (1809-47) 212

Minor theatres, see Illegitimate theatre

Miscellaneity 3-8, 10-11, 15, 19, 43, 49, 57, $74-5,95,103,124-5,186-8,221-7$

Molière, aka Jean-Baptiste Poquelin (1622-73) 129

Molleson, Alexander, writer 117

Moncrieff, William Thomas (1794-1857) 202

Monopoly, theatrical, see Illegitimate theatre

Moody, John (1726/7-1812) 26

Moore, Thomas (1779-1852) 173, 184

More, Hannah (1745-1833) 92, 115, 130, 207-8

Morland, George (1763-1804) 16, 18, 151-4, 161-4

Mozart, Wolfgang Amadeus (1756-91) 177, 206
Munden, Joseph (1758-1832) 189, 192, 194-6

Music halls 7, 100, 126, 132

Musical meaning 35, 109, 116-18, 122-3, $132-3,143,182,214,226$

Napier, Sir William (1785-1860) 209

Napoleon I, Emperor of the French (1769-1821, $r .1804-15) 91,173,175$

Napoleonic Wars 8, 87, 115, 117, 123-4, $129-31,171-3,175,181-2,205$, 207, 209-10, 217, 221-2, 227

Nares, Edward (1762-1841) 99

Navy, see Royal Navy

Nelson, Horatio, 1st Viscount Nelson (1758-1805) 124, 212-13, 216-19

Nile, Battle of the 217

Novosielski, Michael (1747?-95) 53

O'Bryen, Dennis (1755-1832) 69, 74

O'Hara, Kane (1711/12-82) 54

O'Keeffe, John (1747-1833) 80, 125

Old Price Riots 97

Olympic theatre 178, 188, 196

Orientalism 30, 36-42, 98, 105, 173-4, 185,201

Ottoman Empire 30, 39-41, 185

Oxberry, William (1784-1824) 194

Paine, Thomas (1737-1809) 94, 103

Palmer, Joseph (1756-1815) 156

Pantomime, see Harlequin, figure of

Parry, John (1776-1851) 134

Pasquin, Anthony, see Williams, John

Patriotism, see Loyalism and Great Britain: National Character

Peace of Amiens 62, 173

Percy, Thomas, Bishop of Dromore (1729-1811) 61, 213

Perry, James (1756-1821) 69

Phillips, Henry (1801-76) 204-8, 210-16

Pic Nic Society 95-7, 101n, 107

Pilon, Frederick (1750-88) 71n

Pindar, Peter, see Wolcot, John

Piozzi, Hester Lynch (1741-1821) 14

Pitt, Harriet (1748?-1814) 13, 171

Pitt, William the Younger (1759-1806) 8, 72, $85,87,222$

Pitts, John, printer $15,16,128$

Place, Francis (1771-1854) 15, 115

Plumptre, James (1771-1832) 129-30, 145-6

Pocock, Isaac (1782-1835) 192

Poole, John (1785/6-1872) 202

Portugal 209-10

Powell, James, civil servant 99-100, 105

Priestley, Joseph (1733-1804) 94

Print culture 15-16, 18, 31, 55, 64-77, 78-9, 80, 94, 96, 99, 108, 124, 126-8, 131-6, 140-57, 158-67, 184-8, 189-93, 200, 202, 205, 209, 216-17, 226 
Prior, Matthew (1664-1721) 23-4, 30

Private theatricals 17, 94-107, 110

Prussia 94

Puffs 46, 48, 65, 70, 82-3, 99, 137

Race 2, 9, 16, 23-42, 98-9, 111, 141-2, 225-6 Radicalism 8-9, 79, 84-6, 89-90, 92, 100-1, $129,180-1,188,225$

Ranelagh Gardens 4, 12, 16, 62

Rede, Leman Thomas (1799-1832) 26n

Redigé, Paulo the Younger, actor 182

Reeves, John (1752-1829) 86

Religion 40, 87-8, 94, 109, 123, 130, 185-6, $195,197,205-8,212-14,227$

Reynolds, Frederick (1764-1841) 189-92

Reynolds, Sir Joshua (1723-92) 14, 166

Roberts, Piercy, publisher 156-7

Robinson, Henry Crabb (1775-1867) 201

Rowlandson, Thomas (1757-1827) 15, 130-1, 153-6

Royal Academy 154, 164-6, 223-5

Royal Circus 4, 12, 16, 43-58, 62, 66, 172-3, $177-8$

Royal Exchange 75

Royal Navy 4, 8, 19, 63, 85-6, 111, 115, 122, $129,133-4,136,156,163,172,174$ $181,195,205,208-10,214-19$

Russell, Henry (1812?-1900) 134

Russia 24, 43, 175, 181

Ryan, Richard (1750-1818) 124

Rymer, Thomas (1642/3-1713) 70

Sadler's Wells 4, 12, 16, 18, 171-88, 189. See also Aquatic theatre

Sailors, see Royal Navy and Dibdin, Charles: and the sea

Sancho, Ignatius (1729?-80) 26n

Sans Pareil theatre 180,188

Sans Souci 8, 13, 17, 75, 78-81, 84-5, 94-5, $99,101-2,106,110,124-6,134$. $137,146,153$

Sayer, Robert (1724/5-94) 149, 163

Scott, Jane (1779-1839) 180, 188

Scott, Sir Walter (1771-1832) 173, 196

Shaftesbury, Anthony Ashley Cooper, Third Earl of (1671-1713) 10

Shakespeare, William (1564-1616) 7, 25, 27-30, 74, 99-101, 104-5, 132, 186, 193-4, 196

Shelburne, William Petty, Second Earl of (1737-1805) 52

Sheridan, Richard Brinsley (1751-1816) 71, 74, $105 \mathrm{n}, 107 \mathrm{n}$

Shield, William (1748/9-1829) 15

Shuter, Edward (1728?-76) 83

Siddons, Sarah (1755-1831) 13

Slang, see Dialect

Slavery 9, 23, 25-42

Smith, Charles Manby, antiquarian 132
Smith, John Raphael (1751-1812) 18, 161-7

Smollet, Tobias (1721-71) 143

South Africa 25

Southcott, Joanna (1750-1814) 185

Spain 178, 181, 185, 209

Spence, Thomas (1750-1814) 130

Spencer-Churchill, Lady Charlotte (1770-1802) 99

Spencer, Caroline, Duchess of Marlborough (1743-1811) 96

Spencer, George, 4th Duke of Marlborough (1739-1817) 96

Steele, Sir Richard (1672-1729) 67, 75, 117

Stephens, Catherine (1794-1882) 109, 186

Sterne, Laurence (1713-68) 74

Stevens, George Alexander, actor (1710?-84) 103

Stevens, George, journalist (1736-1800) 74n

Stockdale, Percival (1736-1811) 94n

Storace, Ann 'Nancy' (1765-1817) 193

Storace, Stephen (1762-96) 15

Surrey theatre 172, 178, 189

Swan, Isaac, journalist 78-9, 83-4, 92

Swift, Jonathan (1667-1745) 72, 76

Taverns 74, 100, 101, 164, 200

Taylor, Edward (1784-1863) 80, 82, 116 , 125-6, 206

Tennyson, Alfred, 1st Baron (1808-92) 214

Terence, Publius Afer (c.195-c.159 BC) 193-4

Theatre Royal, see Covent Garden theatre, Drury Lane theatre, and Haymarket

Thelwall, John (1764-1834) 7, 8, 226

Thompson, Edward, playwright 174

Thomson, James (1700-48) 61

Topham, Edward (1751-1820) 76

Trafalgar, Battle of 6, 216, 219

Turner, Joseph Mallord William (1775-1851) 218

United States 24, 38, 72, 75, 128, 132-3, 214-15

Universal Songster 15

Vestris, Lucia Elizabeth 'Eliza' (1797-1856) 196

Voltaire, aka François-Marie Arouet (1694-1778) 73, 129

Waldron, Francis Godolphin (1744-1818) 105-6

Ward, William (1766-1826) 151, 153-4, 163

Warren, Sir John Borlase (1753-1822) 124

Waterloo, Battle of 175,181

Watts, Isaac (1674-1748) 187

Wellington, Arthur Wellesley, 1st Duke of (1769-1852) 181

West Indies, see Caribbean

West, Temple (c.1740-83) 44, 66 
Whittle, James 15-16, 149, 157

Wilkes, John (1725-97) 64

William IV (1765-1837, r.1830-7) 134

Williams, John, aka Anthony Pasquin (1754-1818) 67n, 105n, 142, 146, 157

Winston, James, theatre manager 201

Wolcot, John, aka Peter Pindar (1738-1819) 139
Wollstonecraft, Mary (1759-97) 94, 139

Wood, Sir Henry (1869-1944) 6, 219

Woodfall, Henry Sampson (1739-1805) 69,

Woodfall, William (1745-1803)

$$
82-3
$$

Wordsworth, William (1770-1850) 6, 7

Yearsley, Anne (1753-1806) 6

Young, Thomas (1773-1829) 221 